\author{
UNIVERSIDADE DE SÃO PAULO \\ FACULDADE DE FILOSOFIA, LETRAS E CIÊNCIAS HUMANAS \\ DEPARTAMENTO DE HISTÓRIA \\ PROGRAMA DE PÓS-GRADUAÇÃO EM HISTÓRIA SOCIAL
}

\title{
Catálogo de Incunábulos da Biblioteca Vinária de Juan Carlos Reppucci
}

Patrícia de Almeida Giordano

\begin{abstract}
Dissertação apresentada ao Programa de Pós-Graduação em História Social do departamento de História da Faculdade de Filosofia, Letras e Ciências Humanas da Universidade de São Paulo, para obtenção de título de Mestre em História.
\end{abstract}

Orientador: Prof ${ }^{a}$ Dra. Ana Maria de Almeida Camargo

São Paulo 
A meus pais, Íris Maria e Cláudio,

com amor e gratidão pelo carinho e apoio durante este árduo processo. 


\section{Agradecimentos}

Ao Sr. Juan Carlos Reppucci, por possibilitar este trabalho abrindo as portas de sua preciosa biblioteca, com tanta generosidade.

À Dra. Ana Maria de Almeida Camargo, pela caminho acadêmico que me está descortinando, pelos profundos conhecimentos que compartilhou comigo e pela orientação constante e precisa para a realização deste trabalho.

A Cláudio Giordano, meu pai, por tudo. 


\title{
RESUMO:
}

O propósito deste trabalho é a elaboração de um catálogo dos incunábulos de Juan Carlos Reppucci, que possui importante coleção particular de livros de temática vinária (vinhos, vinhedos, uvas, vindima, viticultura, vinicultura, embriaguez etc.). A partir de um histórico dos incunábulos e da imprensa no século XV, e de sucinta caracterização do acervo, cada um dos 72 incunábulos foi minuciosamente descrito, de acordo com normas destinadas a obras raras, de modo a compor um instrumento de referência para pesquisadores de diferentes áreas.

\section{PALAVRAS-CHAVE:}

Incunábulo. História do livro. História da imprensa. Século XV. Vinho.

\begin{abstract}
:
The aim of this work is to catalogue the incunabula collection of Juan Carlos Reppucci, owner of an extensive library on wine and related themes (wine, grape, vineyard, vintage, drunkenness etc.). After a panoramic view of incunabula and press in the $15^{\text {th }}$ century, and a brief characterization of the whole collection, each of the 72 incunabula was thoroughly described according international rules for rare books, in order to create a reference guide for researchers of different areas.
\end{abstract}

\section{KEYWORDS:}

Incunabula. Book history. Print history. $15^{\text {th }}$ century. Wine. 


\section{SUMÁRIO}

1. Introdução

2. Os Incunábulos 10

2.1 Antecedentes: o livro manuscrito e o papel na Europa 13

2.2 Breve histórico e difusão da imprensa na Europa 17

$\begin{array}{ll}2.3 \text { Algumas particularidades dos incunábulos } & 20\end{array}$

3. O Colecionador e sua biblioteca

$3.1 \mathrm{O}$ colecionador 22

3.2 A biblioteca e o acervo de incunábulos 23

$\begin{array}{ll}3.3 \mathrm{O} \text { perfil do acervo } & 25\end{array}$

4. O processo de catalogação 31

5. Como entender o catálogo 35

5.1 Abreviaturas utilizadas 37

5.2 Abreviaturas das referências citadas 38

6. O Catálogo 49

1. CRESCENTIIS, Petrus de. Ruralia Commoda, ca. $1471 . \quad 50$

2. PLATINA, Bartholomaeus. De honesta voluptate et valetudine, 1475 . 53

3. PLINIUS SECUNDUS, Caius. Historia naturalis, 1476.

4. GELLIUS, Aulus. Noctes Atticaes, 1477.

5. HIERONYMUS, Eusebius Sophoronius. Vitae sanctorum patrum, 1478

6. SENECA, Lucius Annaeus. Opera philosophica, 1478.

7. HUGO DE PRATO FLORIDO. Sermones dominicales super evangelia et epistolas, não depois de 1478.

8. NIDER, Johannes. Preceptorium divinae legis, ca. 1475/não depois de 1478.

9. LIVIUS, Titus. Historia romana decades, 1480.

10. PLATINA, Bartholomaeus. De honesta voluptate et valetudine, 1480.

11. BARTHOLOMAEUS ANGLICUS. De proprietatibus rerum, 1481.

12. PLINIUS SECUNDUS, Caius. Historia naturalis, $1481 . \quad 79$

13. BARTHOLOMAEUS ANGLICUS. De proprietatibus rerum, 1482.

14. SCRIPTORES REI RUSTICAE, 1482

15. GRITSCH, Johannes. Quadresimale, 1483. 
16. MENSA PHILOSOPHICA, [ca. 1477-1483].

17. HIERONYMUS, Eusebius Sophoronius (S. Jerônimo). Vitae sanctorum patrum, 1483/84. 93

18. DURANTI, Gulielmus. Rationale divinorum, não depois de 1484.

19. LIVIUS, Titus. Historia romana decades, 1485.

20. HEROLT, Johannes. Liber discipuli de eruditione crristifidelium, não antes de 1485.

21. CRESCENTIIS, Petrus de. Ruralia Commoda, 1486.

22. AUGUSTINUS, Aurelius (S. Agostinho). Sermones sancti augustini ad heremitas, não depois de 1487.

23. AVIENUS, Rufus Festus. Arati phaenomena, 1488.

24. GESTA ROMANORUM, 1488.

25. SALIS, Baptista de. Summa casuum conscientiae, 1488.

26. ALEXANDER APHRODISAEUS. Problemata, 1488-1489. 118

27. PEROTTUS, Nicolas. Cornucopiae linguae latinae, 1489.

28. CRESCENTIIS, Petrus de. Ruralia Commoda (em italiano), 1490.

29. LACTANTIUS, Lucius Coelius Firmicinis. Opera, 1490.

30. TRACTATUES EXCELLENTISSIMUS QUI DE REGIME SANITATIS, [ca. 1490]. 128

31. MESUE, Johannes. Opera medicinalia, 1489-1491. 130

32. MAYRONIS, Franciscus de. Sermones ab adventu cum quadragesmale, 1491/92. 134

33. SENECA, Lucius Annaeus. Opera (em espanhol), 1491.

34. OVIDIUS NASO, Publius. Opera, $1492 . \quad 140$

35. MARTIALIS, Marcus Valerius. Epigrammata, 1493.

36. OVIDIUS NASO, Publius. Metamorfosis, 1493.

37. SCHEDEL, Hartmann. Liber chronicarum (em alemão), 1493.

38. SUETONIUS TRANQUILLUS, Caius. Vitae XII Caesarum, 1493.

39. TIBULLUS, Albius. Elegiae, 1493.

40. AUSONIUS, Decimus Magnus. Opera, $1494 . \quad 159$

41. HORATIUS FLACCUS, Quintus. Opera, $1494 . \quad 161$

42. VALERIUS MAXIMO, Gaius. Facta et dicta memorabilia, 1494.

43. BÍBLIA LATINA, [1495]. 165

44. BERNARDUS CLARAVALLENSIS (S. Bernardo). Sermones de tempore et de sanctis et de diversis, $1495 . \quad 168$

45. GRITSCH, Johannes. Quadresimale, 1495.

46. MARTIALIS, Marcus Valerius. Epigrammata, 1495.

47. SALIS, Baptista de. Summa casuum conscientiae, 1495.

48. TRACTATUS DE VINO ET EIUS PROPRIETATE, [1495]. 178

49. JOHANNES GALLENSIS. De regimine vite humanae, 1496.

50. PLUTARCHUS. Vitae illustrium virorum, 1496.

51. LA VERTU ET PROPRIETATE DES EAUX ARTIFICIELLES, [ca. 1491-1496]. 188

52. ISIDORUS, Hispalensis. De summo bono, [1492-1496]. 191

53. BÍBLIA LATINA, 1497. 
54. BONAVENTURA, Santo. Dieta salutis, 1497.

55. GEMINIANO, Johannes de Sancto. Summa de exemplis et similitudinibus rerum, 1497.

56. MARULLUS, Michael Tarchaniota. Hymni et epigrammata, 1497.

57. PARALDUS, Gulielmus. Summa de virtutibus at vitilis, 1497.

58. FICINUS, Marsillius. De triplici vita, 1498.

59. HORATIUS FLACCUS, Quintus. Opera, 1498.

60. PLATINA, Bartholomaeus. De honesta voluptate et valetudine, 1498.

61. POLITIANUS, Angelus. Opera omnia, 1498.

62. ALBERTUS MAGNUS. Liber de mulieri forti, 1499.

63. ALBERTUS MAGNUS. Liber de mulieri forti, 1499.

64. BEROALDUS, Philippus. Declamatio lepidissima ebriosi scortatoris aleatoris de vitiositate disceptantium, 1499.

65. GEMINIANO, Johannes de Sancto. Summa de exemplis et similitudinibus rerum noviter impressa, 1499.

66. PLINIUS SECUNDUS, Caius. Historia naturalis, 1499.

67. POLITIANUS, Angelus. Opera omnia, 1499.

68. AUGUSTINUS, Aurelius (S. Agostinho). Divi augustini in sacras pauli epistolas, 1499.

69. SCRIPTORES REI RUSTICAE, 1499.

70. TESTAMENT DE TASTE DE VIN ROY DES PIONS, 1499.

71. BARTHOLOMAEUS ANGLICUS. De proprietatibus rerum, 1500.

72. REGIMEN SANITATIS, [1500-1503].

7. Referências

8. Glossário

9. Apêndice: as filigranas

10. Anexos
A. Registro GW
B. Registro ISTC
C. Reportagem do New York Times 


\section{Introdução}

Desde que me iniciei no universo dos livros, através da encadernação e, posteriormente, pelo restauro, sentia vontade e necessidade de estudá-los mais a fundo: pesquisar as encadernações antigas e suas estruturas, a evolução da encadernação juntamente com a história do livro. Mas como aprofundar tema tão amplo? Que caminho seguir? Havia que fazer escolha por um período, um tipo de encadernação, ou mesmo um acervo específico. Por muito tempo busquei um tema, que possibilitasse esse estudo e ao mesmo tempo despertasse a paixão necessária para que eu pudesse levar a cabo tal projeto, apesar das dificuldades e incertezas.

Nessa busca surgiu a Biblioteca Vinária de Juan Carlos Reppucci (BVR), cujo magnífico acervo é, sem dúvida, uma grande fonte de material de estudo. Então, dentre suas obras raras, escolhi para minha aventura de pesquisa, os incunábulos, os livros impressos mais antigos, e em quantidade bastante representativa na BVR.

Este conjunto de incunábulos, além de ser de indiscutível relevância para estudo da história do livro, fornece elementos fascinantes em relação à história da encadernação e das intervenções sofridas por estes objetos em seus mais de cinco séculos de existência, seja pelo manuseio, "vandalismo", ou mesmo troca de encadernação e restauro.

Konrad Haebler, um dos mestres no estudo da incunabilística, na introdução de seu trabalho Introducción al estudio de los incunables, logo adverte da amplitude e complexidade do tema e se mostra receoso de satisfazer as expectativas do leitor com sua obra. Ressalto a colocação de Haebler, por achá-la pertinente na apresentação deste trabalho, pois além das dificuldades provenientes da temática, há também as dificuldades de tratar de estudo de um tema anterior à descoberta do Brasil e do desenvolvimento de nossa nação como tal, onde o próprio surgimento da imprensa é tardio, posterior aos demais países do Novo Mundo. E juntos, estes fatores contribuem para a escassez de bibliografia, de estudos e pouca pesquisa nesta área.

O estudo teórico dos incunábulos em si já seria suficientemente profundo e extenso para gerar uma pesquisa, sem a necessidade de se atrelar a um catálogo; mas, provavelmente haveria dificuldade de encontrar-se material para a pesquisa, tanto bibliográfico como acervos de incunábulos, e assim nada acrescentaria aos trabalhos existentes sobre a história do livro. Desta forma, me pareceu oportuno, com o "pretexto" da elaboração de um catálogo, ir além e elaborar modesta introdução ao universo dos 
incunábulos - sem a pretensão de sequer aproximar-me de trabalhos do porte de Haebler ou outros estudiosos que se dedicaram exaustivamente ao assunto. Visamos então criar um material didático para quem queira entender um pouco sobre os primeiros livros impressos exemplificados através deste catálogo, tornando ao mesmo tempo exaustiva a descrição deste último, para que sirva de instrumento de referência para pesquisadores, no tocante a informações específicas sobre os exemplares presentes na coleção Reppucci.

Aproveito também esta introdução para explicar o uso da palavra vinária ao nomear a biblioteca que é objeto deste estudo. Perguntaram-me mais de uma vez: por que não usar o termo relativo a enologia? não seria mais apropriado? Para responder, nada melhor que a imagem do ex-libris do colecionador, que supostamente é a pessoa mais qualificada para escolher o nome de seu próprio acervo.

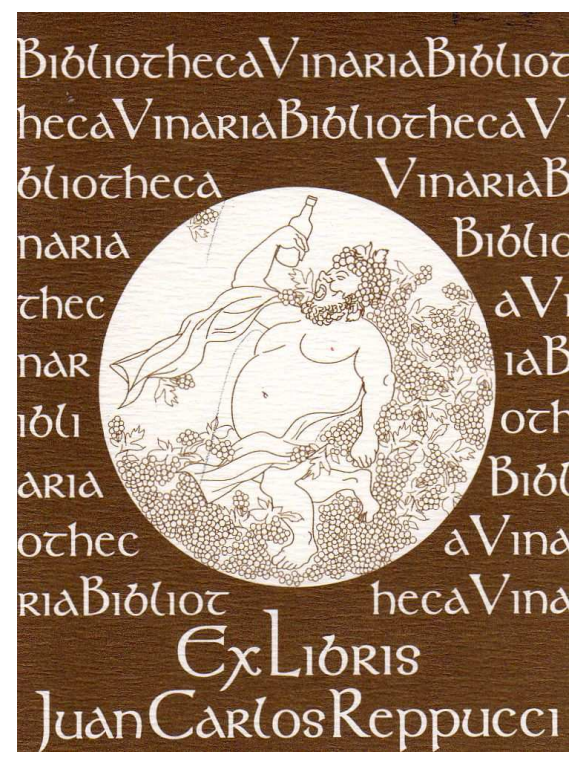

No caso desta explicação não ser suficiente, recorro ao MICHAELIS (1998) e encontro estas definições:

Enologia: $s f$ Ciência e arte do cultivo da vide e preparação do vinho. Adj. Enológico.

Vinário: adj. (lat vinariu) 1 Relativo a vinho. 2 Próprio para conter vinho.

Assim, considerando a primeira acepção de vinário, pode-se constatar que o termo é muito mais amplo e adequado para o uso feito aqui, o que se elucidará ainda mais no decorrer do trabalho, ao serem apresentadas as obras contidas no acervo e seus respectivos assuntos. Ilustremos antecipadamente com um exemplo: a obra de Ovídio, clássico da Literatura latina, trata da paixão pelo vinho, ou seja relativa ao vinho e não relativa ao cultivo da vide e preparação do vinho. 


\section{Os Incunábulos}

Incunábulo é o termo utilizado para designar qualquer manifestação primitiva de arte ou atividade; indica início, começo, berço. Em relação aos livros, emprega-se a mesma terminologia para referir-se aos primeiros livros publicados em um país ou em uma língua; o uso mais comum, porém, refere-se aos primeiros livros impressos. É esta a definição que adotamos neste trabalho: incunábulo é toda obra impressa da origem da imprensa até o dia $1^{\text {o }}$ de janeiro de 1501 , independentemente de país ou língua.

Os incunábulos são os precursores do livro como hoje o conhecemos; representam a evolução da arte da impressão até atingir a sua maturidade, a transição das tradições artísticas e eruditas para métodos mais modernos e profissionais. Os primeiros incunábulos se assemelhavam aos manuscritos: não havia nenhuma informação na primeira folha, os tipos imitavam a caligrafia da época, inclusive nas ligaduras ${ }^{1}$ e abreviações.

Na Alemanha, no final do século XV, é que alguns ateliês ou oficinas, como a de Anton Koberger (Nuremberg), Johann Grüninger (Estrasburgo) e Peter Drach (Espira), começaram a mecanização do processo de impressão, apesar de não se desvincularem totalmente da concepção erudita e artística (característica dos incunábulos). Os demais ateliês estão nesse momento ainda muito atrás, e para eles o período poderia se estender até a Reforma (primeiras décadas do século XVI).

Na Itália, Veneza, por ser o centro comercial da Europa, teve sua imprensa rapidamente desenvolvida e já se poderia falar no final do período incunábulo em 1480, diferente das demais cidades italianas onde a evolução tipográfica foi mais lenta. Mas com a introdução da tipologia itálica por Aldo Manuzio, em 1501, reafirma-se o surgimento de uma nova era para a arte tipográfica e confirma-se a data de 1500 para o fim dos incunábulos.

O mesmo acontece na França: em Paris, a evolução da arte de imprimir, embora mais lenta que a de Veneza (meados dos anos 1490), foi muito maior que a de outras cidades. Espanha e Inglaterra não tiveram centros de destaque onde a arte da imprensa se desenvolvesse mais que no âmbito provinciano, como no caso de Veneza ou Paris. Assim, em muitos casos, poder-se-iam considerar incunábulos os livros impressos até 1550, dado o

\footnotetext{
${ }^{1}$ As palavras constantes no glossário aparecem em destaque na primeira ocorrência no texto.
} 
desenvolvimento tardio da tipografia, com a presença de características da imprensa primitiva.

Pode-se questionar a escolha da data limítrofe, uma vez que o desenvolvimento foi diferente de um país para outro, e mesmo entre as suas cidades, mas o ano de 1500 é hoje aceito por determinar uma data intermediária da evolução da imprensa em diferentes países e ser um limite apropriado para a Alemanha, país de origem da imprensa.

O interesse pelo estudo dos primeiros livros impressos não é recente: Haebler considera 1640 como o ano do nascimento da incunabilística, quando, por ocasião da comemoração dos duzentos anos da invenção da imprensa, em várias cidades alemãs tomase a iniciativa de catalogar estas primeiras obras. Em 1643 surge o apêndice de Johann Saubert com 825 incunábulos da Biblioteca de Nuremberg; em 1653 a obra de Philippe Labbé apresenta um suplemento com 1289 incunábulos da Biblioteca Real de Paris e é quando o termo incunábulo é utilizado pela primeira vez associado à imprensa; depois destes trabalhos seguem-se outros repertórios, cada vez com número maior de obras e gradativo avanço nas informações bibliográficas.

No final do século XVIII e início do XIX os Annales de Panzer $^{2}$ (os incunábulos são organizados pela primeira vez por países e local de impressão, ordenados cronologicamente, e com indicação da localização ou da origem da fonte de informação) e o Repertorium de Hain $^{3}$ (através da descrição textual detalhada do Incipit e Explicit, e de notas descritivas quanto a formato, tipo de letra, composição etc, fornece pela primeira vez uma identificação indiscutível dos incunábulos que teve em suas mãos) foram revolucionários e ainda hoje são base para o estudo dos incunábulos.

A partir de Hain, que havia registrado 16.299 obras, diversos catálogos surgiram com enfoque centrado em oficinas tipográficas, cidades, regiões ou acervos específicos; mas são os suplementos de Copinger ${ }^{4}$ e Reichling ${ }^{5}$ com suas correções e acréscimos

\footnotetext{
2 George Wolfgang Franz Panzer. Annales typographici ab artis inventae origine ad annum MD. Norimbergae, J. E. Zeh, 1793-1803. Vol. I-V e suplementos nos vol. IX-XI (os volumes de VI-VIII tratam de obras posteriores a 1501)

${ }^{3}$ Ludwig Hain. Repertorium bibliographicum, in quo libri omnes ab arte typographica inventa usque ad annum MD. Typis expressi ordine alphabetico vel simpliciter enumerantur vel adcuratius recensentur. Stuttgartiae \& Lutetiae Parisiorum, 1826-1838.

${ }^{4}$ Walter Arthur Copinger (foi Presidente da Sociedade Bibliográfica de Londres). Supplement to Hain's repertorium bibliographicum or Collections towards a new edition of that work: In two parts. The first containing nearly 7000 corrections of and additions to the collations of works described or mentioned by Hain. The second, a list with numerous collations and bibliographical particulars os nearly 6000 volumes printed in the Fiftheenth Century, not referred to by Hain. London, 1895-1902.
} 
significativos à obra de Hain que se tornam essenciais para os incunabilistas, juntamente com as novidades apresentadas pelo Index idealizado por Proctor ${ }^{6}$ (o mérito de Proctor não se deu pela sua descrição do acervo, que não foi profunda, mas pelo método desenvolvido, agrupando as obras por lugares e impressores) e pelo Typenrepertorium de Haebler ${ }^{7}$ (minucioso estudo dos tipos utilizados nos incunábulos). A lista de obras de referências se estende e não vamos nos prolongar neste tema já que em nosso catálogo muitas delas são citadas e comprovam sua utilidade, mas esta sucinta apresentação histórica da incunabilística nos parece fundamental para mostrar a complexidade do tema que ainda possibilita tantas pesquisas e descobertas. Encerramos estes apontamentos, registrando dois catálogos unificados de extrema importância, a saber:

1) Gesamtkatalog der Wiegendrucke $(G W)$ : projeto que se iniciou através da criação na Alemanha de uma Comissão em 1904 para inventariar as coleções alemãs, e posteriormente com a participação de outros países para a criação de um repertório unificado dos incunábulos; entre os anos de 1925 e 1940 publicaram-se sete volumes, publicação interrompida com a eclosão da Segunda Grande Guerra; hoje esse projeto dá nome ao banco de dados disponível na internet, oferecendo 36.000 descrições de incunábulos e é um trabalho ainda em andamento.

2) Incunabula Short-List Catalogue (ISTC): banco de dados também disponível na internet e que vem sendo desenvolvido pela British Library desde 1980, tendo 29.777 edições arroladas até janeiro de 2008. Apesar de não descrever as obras, fornece referências bibliográficas que possibilitam a identificação complementar do exemplar e localização dos exemplares conhecidos.

Para mostrar a complexidade das informações obtidas nestes bancos de dados, acrescentamos nos anexos dois registros (GW e ISTC), da obra Gesta Romanoram, $\mathrm{n}^{\circ} 23$ deste catálogo.

\footnotetext{
5 Dietrich Reichling. Appendices ad Hainii-Copingeri repertorium bibliographicum. Additiones et emendationes. Monachii, Sumptibus Iac. Rosenthal Librarii Antiquarii, 1905-1911. 7 vols. Supplementum (Maximan partem e Bibliothecis Helvetiae collectum). Cum Ondice Vrbium et Typographorum. Accedit Index Auctorum Generalis totius operis. Monasterii Guestphalorum, Sumptibus Theissingianis, 1914.

${ }^{6}$ Robert Proctor. An index to the early printed books in the British Museum: from the invention of printing to the year MD. With notes of those in the Bodleian Library. London, Kegan Paul, Trench, Trübner and Company, 1898. 2v.

${ }^{7}$ Konrad Heabler. Typenrepertorium der Wiegendrucke.
} 


\subsection{Antecedentes: o livro manuscrito e o papel na Europa}

Para bom entendimento do que representou o desenvolvimento da imprensa de tipos móveis no Ocidente, é preciso voltar um pouco no tempo e ver como eram a sociedade e a cultura do século XV, o que motivou tal avanço, como era o universo do livro, sua produção, seu público.

Falar da história do livro desde sua origem, levar-nos-ia à Antiguidade, às escritas primitivas, aos precursores do livro atual (rolos de papiro, tabletes de cera, dípticos e trípticos), numa longa viagem, não só cronológica mas também através das diversas disciplinas que se interagem (paleografia, codicologia, história do papel, história da arte); aqui nos limitaremos ao momento histórico que levou à descoberta da imprensa e situa os incunábulos em seu tempo e diante de seus percussores: os livros manuscritos.

No início da Idade Média, apenas o alto clero era letrado; a maior parte dos nobres, muitos padres e o povo em geral não sabiam ler e escrever. Mas é equivocado dizer por isso que todo esse mundo de analfabetos era inculto: a prática da leitura oral e coletiva era comum e possibilitava a instrução. A comunicação oral prevalecia como principal forma de transmissão de tradições, histórias e conhecimento para o homem comum.

É na Idade Média, com o Cristianismo dando um status sagrado ao livro, que este passa a ter sua história indissociável ao da civilização ocidental. O livro tinha um papel da maior relevância, sendo utilizado durante a liturgia ou em estudos monásticos, estando presente nos juramentos e nas procissões com suas páginas iluminadas abertas, ou fechado, exibindo suas luxuosas encadernações e impondo-se assim perante os fiéis. Se ainda hoje nos maravilha e fascina um livro manuscrito com suas iluminuras, pode-se supor a admiração que causava em uma população como a da Europa do século VIII, por exemplo.

Pouco a pouco o universo letrado vai-se expandindo, a princípio através das escolas paroquiais, pois era função da Igreja a educação das crianças. Gradativamente aumentam os leigos letrados, os interesses se ampliam assim como a relação dos leitores com os livros: monges com suas meditações sobre as escrituras sagradas, senhoras devotas e seus Livros de Horas, o divertimento das princesas com os romances e dos príncipes com tratados de caça, e estudiosos que se perdem entre os livros de filosofia, gramática, história natural ou medicina.

Os livros não se limitavam ao texto; possuíam um fabuloso repertório de imagens que os complementavam e enriqueciam; quanto mais importante o dono, mais ornamentada 
era a obra. Para a nova sociedade que começa a surgir, sedenta de conhecimento, o livro se torna um de seus maiores símbolos, objeto de desejo e paixão. Tanto eram valiosos, que em algumas bibliotecas medievais podiam encontrar-se os libri catenati, ou seja, livros acorrentados às estantes em que eram consultados, para evitar que fossem roubados.

O livro era um bem precioso, e uma forma de compreender o seu valor é conhecer sua produção. O suporte utilizado então era o pergaminho e para obras ainda mais especiais o velino; somente no século XIII o papel chega ao Ocidente, não sendo a princípio muito utilizado por ser considerado frágil. O pergaminho sempre foi um material caro, pois para a obtenção de cada pele era necessário o abate de um animal e seu preparo podia demorar até quinze dias. Os pergaminhos deviam ser polidos e preparados com gesso pelos copistas para só então receber a escrita. As tintas para a escrita e os pigmentos utilizados na decoração dos códices eram preparados pelos próprios copistas e iluminadores respectivamente, que igualmente preparavam seus cálamos e suas plumas. A quantidade de cores utilizadas (algumas eram mais caras, como o azul), assim como o uso de folhas de ouro na decoração de uma obra, também encareciam um livro. E mais que tudo, a confecção do livro manuscrito era demorada. No século XI, um monge copista, tendo outras obrigações e tarefas no mosteiro e dedicando portanto apenas uma parte do tempo a esta atividade, podia concluir três ou quatro livros de tamanho médio ${ }^{8}$ por ano; sabe-se de projetos de manuscritos cuja produção durou anos (HAMEL, 1999).

Há diversos registros do custo de um livro na época; dada a dificuldade de compreender o valor da moeda medieval, o exemplo de CASSAGNES-BROUQUET (2003, p.26) nos parece elucidativo: "Para um letrado do século XV, a compra de um livro representa, a grosso modo, o equivalente a doze dias do salário de um secretário da chancelaria real, de um oficial muito bem pago"'.

A evolução do livro se torna irreversível com o surgimento das primeiras universidades a partir do século XII. A necessidade de livros passa a ser cada vez maior; humanistas e estudantes copiam os textos que tinham mais importância para eles e trocamnos entre si. Surgem as primeiras livrarias que funcionavam conjuntamente com oficinas onde se produziam livros por encomenda e empregavam estudantes menos abastados como copistas, que tinham assim como pagar seus estudos. A produção se agilizava; as abreviaturas que já eram utilizadas há tempos se tornam cada vez mais complexas, surge o

\footnotetext{
${ }^{8}$ Provavelmente um livro in-folio pequeno ou in- $4^{\mathrm{o}}$ de aproximadamente 150 folhas.

${ }^{9}$ Trad. nossa.
} 
sistema de pecia ${ }^{10}$, e um livro podia ser confeccionado em questão de dias e não mais meses. A indústria de produção de manuscritos também era estimulada pela expansão da classe média, que buscava obras contemporâneas de prosa e poesia, além da religiosa, agora também em linguagem vernácula.

É neste contexto, de uma sociedade sedenta por livros, cuja produção artesanal apesar de agora mais ágil, ainda é lenta, onerosa e incapaz de atender à demanda, que se desenvolve a imprensa de tipos móveis na Europa do século XV, mais precisamente na Alemanha. Note-se, porém, que a concepção de imprimir com tipos móveis não foi original: na China esta técnica já era utilizada desde o século XI, mas dada à dificuldade do idioma chinês, que possui inúmeros signos, chegando a necessitar entre quatro e cinco mil ideogramas diferentes para a confecção de um único livro, esta prática não foi revolucionária como viria a ser no Ocidente onde o alfabeto latino é composto de poucos caracteres.

Para o desenvolvimento da imprensa, o papel foi peça fundamental e imprescindível. Sem sua chegada ao Ocidente, o desenvolvimento da prensa de tipos móveis não seria revolucionário, pois a produção de pergaminho não seria suficiente para atender a demanda de que o novo meio necessitava.

O papel surge na China no início do século II, e o consenso dos historiadores atribui a descoberta a Ts'ai Lum em 105 d.C, na província de Honan. O processo consistia na maceração das fibras (inicialmente fibras vegetais obtidas de trapos e redes de pesca e, posteriormente, linho, cânhamo, rami e amoreira), que depois eram batidas e esmagadas, resultando em uma pasta que era dispersa em água; ao submergir o molde nesta solução, a folha de papel se formava sobre ele. A secagem das folhas, que podiam ou não ser retiradas do molde, era ao ar livre, e finalizava-se o processo brunindo as folhas com uma pedra lisa e impermeabilizando-as com uma solução de algas ou de seivas. Os moldes eram semelhantes a peneiras, que deixavam a água escorrer mas retinham as fibras de celulose, que formavam o papel. Na China os moldes eram confeccionados com finíssimos juncos ou bambus, unidos por fios de seda ou crina e fixados em uma armação de madeira. Amostras que chegaram aos dias de hoje demonstram que o papel obtido era de alta qualidade.

Os Chineses procuraram manter a tecnologia da fabricação do papel em segredo para o resto do mundo, e conseguiram este feito até 751d.C., quando os árabes ganharam a

\footnotetext{
${ }^{10} \mathrm{O}$ sistema de pecia (significa peça em latim) foi usado a partir do século XIII e consistia na aprovação pela universidade da divisão de um exemplar em cadernos para que pudessem ser copiados. Nem todos os livros, mesmo os de uso escolar, eram disponibilizados através do sistema de pecia (BROWN, 1994).
} 
batalha em Samarcanda contra os chineses e assimilaram o processo, ao capturar alguns chineses que dominavam esta arte. Samarcanda logo se torna um grande centro produtor de papel, favorecido pelo cultivo local de linho e cânhamo, e principalmente, pela cultura árabe, que vê no papel todo seu potencial para a expansão do conhecimento e manifestações de arte; a partir daí, o papel vai acompanhar a expansão mulçumana ao longo da Ásia Menor e do norte da África, entrando na Europa pela Península Ibérica, e mais tarde por outra rota chega à Sicília. Para ilustrar o desenvolvimento da produção papeleira, vejam-se alguns dados da cronologia do papel (HUNTER, 1978):

$$
\begin{aligned}
& 793 \text { - Bagdá, Iraque } \\
& 900 \text { - Cairo, Egito } \\
& 1100 \text { - Fez, Marrocos } \\
& 1151 \text { - Játiva (S. Felipe de Játiva), Espanha } \\
& 1276 \text { - Fabriano, Itália } \\
& 1293 \text { - Bolonha, Itália } \\
& 1348 \text { - Saint-Julien, França } \\
& 1390 \text { - Nuremberg, Alemanha } \\
& 1405 \text { - Flandres, Bélgica } \\
& 1491 \text { - Pradnik Czerwony, Polônia } \\
& 1495 \text { - Hertfordshire, Inglaterra }
\end{aligned}
$$

Essas são as datas aproximadas do surgimento dos primeiros moinhos papeleiros de alguns paises, mas é preciso lembrar que o uso do papel é anterior à produção local, ou seja, primeiro o papel é importado de outros centros produtores, e pouco a pouco, com sua importância consolidada na sociedade, a produção de papel passa a ser um bom negócio.

É oportuno destacar alguns aspectos do desenvolvimento técnico do papel. Apesar dos chineses utilizarem, nos primórdios da produção papeleira, redes de pesca e trapos, logo estes foram substituídos dado o potencial de suas plantas como a casca da amoreira ${ }^{11}$, rami, cânhamo e bambu. Coube aos árabes a re-introdução da reciclagem do trapo na produção do papel, além da confecção de moldes de malha metálica e do uso do amido de trigo para a colagem (etapa equivalente à impermeabilização realizada pelos chineses).

A importância do papel para a imprensa é decisiva, pois não é apenas a produção de pergaminhos que não atenderia às necessidades do novo meio de reprodução: ele também não era o suporte ideal; o pergaminho não recebia bem a tinta de impressão e somente os

\footnotetext{
${ }^{11}$ A amoreira chinesa é diferente da encontrada no ocidente que não é adequada para a produção de papel.
} 
mais delicados velinos adequavam-se à movimentação sob a prensa. Mas é comum pensar que o papel era um material mais barato que o pergaminho e que esta foi a principal razão para sua adoção pelos impressores. O papel também era um material caro, mas o diferencial era a possibilidade da produção em grandes quantidades e a sua superfície lisa. Com a disponibilidade do novo suporte, que se tornou abundante na Europa do século XV, a impressão por tipos móveis tem agora todos os elementos necessários para se desenvolver; é por isso que para FEBVRE e MARTIN (1992, p.43), a criação das Universidades e seu desenvolvimento no século anterior, que fizeram com que a demanda pelos manuscritos fosse cada vez maior, não foram suficientes para a imprensa surgir antes, pois faltava o suporte e a quantidade necessários para provocar a transformação.

\subsection{Breve histórico e difusão da imprensa na Europa}

Ainda antes de avançar na aventura da imprensa, resta-nos mencionar o livro xilográfico na Europa ${ }^{12}$. Já se conheciam há muito tempo técnicas para a reprodução de figuras, ou para ornar as encadernações monásticas (pressão de uma matriz de metal em relevo sobre o couro) ou para estampar tecidos (carimbos de madeira entintados e aplicados sobre tecidos de linho ou seda). Com o surgimento do papel como suporte, estas imagens ganham maior precisão e nitidez que as realizadas sobre tecido. No final do século XIV a simplicidade do processo, que exigia apenas um instrumento de corte para esculpir e blocos de madeira, e permitia a execução de múltiplas impressões a partir de uma única matriz, logo atinge sucesso e, consequentemente, se espalham imagens iconográficas populares (santos, passagens bíblicas, lutas entre anjos e demônios), antes encontradas apenas nas igrejas; posteriormente cartas de baralho e, enfim, os primeiros livros xilográficos. O que se inicia como uma inscrição, a principio manuscrita e depois também entalhada, de uma legenda ou um texto em uma bandeirola em uma imagem de santo, aos poucos se transforma em pequenos textos de aspecto religioso ou moral, populares na época:

Muito depressa também, uma simples folha não é mais suficiente; apareceram, então os libretos xilográficos, formados, como os livros, de cadernos de um formato correspondendo geralmente ao nosso pequeno in-4 ${ }^{o}$. Toda uma literatura se desenvolveu assim; encontravam-se neles os temas religiosos e morais mais populares da época: Apocalipses figurados, Bíblias dos Pobres, Histórias da Virgem ou ainda Espelhos da Redenção, Paixões de Cristo, Vidas dos Santos, Artes de Morrer etc.

\footnotetext{
${ }^{12}$ Para não estender demasiadamente o tema não mencionaremos o livro xilográfico no Oriente, que surge bem antes.
} 
Pequenos libretos, nos quais o texto ganhava importância ao lado da ilustração, davam aos "pobres clérigos", isolados, exemplos para a preparação de seus sermões e para o ensino da religião. Sobretudo por seu preço e por sua concepção, pela primeira vez, eles tornavam o livro acessível às classes populares; mesmo aqueles que não sabiam ler podiam compreender o sentido dessas sequências de imagens e aqueles que possuíam alguns rudimentos -- o próprio sucesso desses libretos cujo texto ganhava uma importância crescente parece provar que eles eram numerosos -- seguiam mais facilmente as explicações por elas estarem redigidas em língua vulgar. (FEBVRE; MARTIN, 1992, p. 71-72)

Entretanto a impressão através de tipos móveis não é uma evolução do livro xilográfico: ambos são processos distintos; o último não utiliza prensa, não sendo portanto um processo de impressão, e sim de estampa. O livro xilográfico tem vida curta; surge no século XV quase concomitante com a imprensa, e as duas técnicas coexistem até o final do século, deixando o xilográfico de ser produzido face às dificuldades de produção em comparação com a praticidade da técnica de impressão; mas o ofício da produção de estampas permanecerá e manterá seu papel de destaque até o surgimento da fotografia, além de logo fazer parte dos livros. ilustrando-os. Pode-se dizer que o livro xilográfico lança a semente e "dá um gostinho" ao que viria a ser o livro impresso: às novas possibilidades que se abririam e aos limites que seriam rompidos.

O desenvolvimento da imprensa de tipos móveis dependia da solução de três problemas: a confecção dos tipos, da prensa e a obtenção da tinta apropriada. Entre estes, foi a criação dos tipos que realmente exigiu maior dedicação e empenho. Impunha-se descobrir o metal mais apropriado para cada etapa: pois primeiro era necessária a confecção de uma punção em metal duro (de início latão ou bronze e posteriormente o aço); depois criar com esta punção as matrizes (de chumbo e depois cobre) para nelas fundirem-se os tipos com uma liga metálica à base de chumbo, estanho e antimônio, mas que podia conter também outros metais, como cobre, prata ou ferro ${ }^{13}$. As dificuldades iniciais do processo exigiam que os próprios tipógrafos tivessem que produzir suas fontes para impressão e foi por isso que a nova arte surgiu entre ourives, moedeiros e medalhistas, profissões com as aptidões e os conhecimentos necessários para esta perícia.

Apesar de nenhum incunábulo trazer inscrições que comprovem seu mérito, hoje há consenso em atribuir a descoberta da prensa de tipos móveis a Johann Gensfleisch, ou

\footnotetext{
${ }^{13}$ Para entender a dificuldade de obter a liga adequada para a fundição dos tipos, até o século XVIII não se tinha alcançado a combinação ideal, que é uma composição de chumbo, estanho e antimônio em proporções precisas para se alcançar a máxima resistência.
} 
Gutenberg, de Mogúncia. Dá-se como sendo a primeira obra datada o Saltério de Mogúncia, de Johann Fust e Peter Schöffer, de 14 de outubro de 1457; mas não se trata de uma experiência: sua execução perfeita comprova que esta obra era o resultado de pesquisas anteriores e que outros trabalhos já deveriam ter sido realizados. A obra mais antiga que pode ser datada com certa segurança é o Calendário Astronômico para 1448, publicado provavelmente em Mogúncia; entre 1450 e 1455 várias oficinas já funcionavam, publicando diversas obras, como gramáticas resumidas, calendários e cartas de indulgências. Em 1450 Gutenberg, ourives e de família de moedeiros, se associa a Fust, rico burguês, que financia seus projetos para produção de livros ${ }^{14}$, mas em 1455 este o acusa de não cumprir o combinado e Gutenberg é condenado e assim perde tudo. Dois anos depois, Fust e Schöffer (um dos antigos aprendizes de Gutenberg) publicam o Saltério de Mogúncia. Acredita-se que antes disso Gutenberg tenha executado outras obras, como a Bíblia de 42 linhas, que foi a primeira grande produção impressa e teria sido o provável motivo do pleito com Fust. Estas teorias são reforçadas por processo anterior (1439) que envolveu Gutenberg em Estrasburgo. Documentos que chegaram a nós desta disputa com os irmãos Dritzehn comprovam que já em 1436 Gutenberg tinha conhecimentos secretos, que eram o objeto da disputa e estes envolviam uma "arte nova"; pode-se assim supor que ele já trabalhava com impressão. Vale registrar a existência de indícios de que outros pesquisadores também estudavam o tema em diferentes partes da Europa, como é o caso do ourives Prokop Waldvogel, cujos documentos de Avignon, datados de 1444 a 1446, mencionam a ars scribendi artificialiter (arte de escrever artificialmente); mas pelas dificuldades de interpretação dos termos utilizados não se pode precisar qual era o seu progresso.

A letra gótica de missal foi o modelo escolhido por Gutenberg para a Bíblia de 42 linhas e este tipo de caracteres foi adotado pelos impressores alemães até aproximadamente 1464, quando Adolf Rusch, em Estrasburgo, emprega pela primeira vez os tipos romanos que logo são difundidos e atingem a perfeição com Nicolas Jenson em Veneza. A partir de 1470 a tipografia se expande pela Europa e, apesar de geralmente introduzida por mestres alemães, os italianos rapidamente passam a dominar a arte da impressão.

Nas duas últimas décadas do século XV, os resultados obtidos até então serão agora aperfeiçoados, e superadas as imperfeições. Além disso, as obras impressas deixam de

\footnotetext{
${ }^{14}$ Documentos do pleito de Gutenberg e Fust mencionam a "fabricação de instrumentos", o "trabalho dos livros", a compra de materiais como papel, pergaminho e tinta, que comprovam as pesquisas de Gutenberg e seus resultados, ou da proximidade que ele estava de alcançá-los.
} 
apenas reproduzir obras do passado e passam a dar espaço à produção intelectual contemporânea. Citando Haebler "[...] podemos quase acreditar que para o ano de 1500 a imprensa já havia alcançado a forma na qual se transmitiu à posteridade. É este processo de crescimento o que dá ao estudo dos incunábulos um atrativo especial" (1998, p. 65) ${ }^{15}$, aproveitamos para ratificar a data definida como final para o estudo dos incunábulos.

Nos dias de hoje em que os meios de comunicação são tão diversificados, dinâmicos e eficientes, onde podemos falar por telefone instantaneamente com familiares e amigos em outro continente, as cartas são cada vez mais substituídas por fax e e-mails, e notícias de acontecimentos ocorridos pelo mundo afora são divulgadas diariamente nos telejornais, é-nos difícil imaginar o quanto significou o impacto que produziu a descoberta de Gutenberg no século XV; creio que nos ajuda a visualizá-lo esta passagem de Laurence Hallewell:

As cidades da cristandade, no fim da Idade Média, ainda eram pouco mais que refúgios isolados de indústria caseira em um deserto rural de auto-suficiência feudal, separadas umas das outras por uma multiplicidade de insignificantes reinos permanentemente em guerra. "Viajar" entre eles, por terra, mesmo em tempo de paz, ainda acarretava muito "trabalho": um arrastado e deselegante passo de uma besta de carga ao longo de caminhos infestados de ladrões e que eram apenas transitáveis metade do ano. Em tais circunstâncias, a rapidez com que a impressão a partir de tipos móveis foi adotada e expandida é um notável tributo ao significado da nova invenção. (HALLEWELL, 1985, p.1)

\subsection{Algumas particularidades dos incunábulos}

A maioria das características dos incúnabulos não é exclusiva do período, não existindo regras para se determinar se uma obra é ou não um incunábulo, nem caracteristicas isoladas que asseguram que o seja. Na ausência de colofão ou informações na própria obra, faz-se necessário um estudo de diversos fatores que conjuntamente tornem viável a identificação.

Atualmente há poucas edições totalmente desconhecidas ou sem nenhum tipo de identificação, e por ser o catálogo o principal objetivo deste estudo, e não um tratado sobre a incubabilistica ou métodos para a identificação de incunábulos, serão apresentadas aqui apenas particularidades ou caracteristicas do período, que, por serem muito distintas das

\footnotetext{
${ }^{15}$ Trad. nossa.
} 
atuais, possam auxiliar na compreensão da evolução ocorrida, das dificuldades existentes e consequentemente da importância de nosso objeto de estudo.

Como vimos, a tipografia nascente imitava os livros manuscritos, nos quais eram abundantes as ligaduras e abreviaturas, que tinham a função de, encurtando o texto, economizar pergaminho e agilizar a produção. Tais recursos, mesmo sendo contraproducentes para a nova prática - pois exigiam a confecção de inúmeros caracteres especiais mantiveram-se até os primórdios do século XVI. Esses caracteres especiais, oneravam tanto o trabalho de composição, quanto o de fundição dos tipos, que se desgastavam rapidamente.

A decoração das inciais se manteve, e nos primeiros livros deixavam-se espaços (retangualares ou quadrados) em branco para que o rubricador depois pintasse a inicial em vermelho, vermelho e azul ou com pequenas iluminuras. Em razão dos erros que ocorriam, instituiu-se imprimir no centro deste espaço a inicial a ser decorada, em geral letra minúscula, provisória, chamada de letra-guia ou de espera. Com o surgimento dos livros ilustrados, a maioria com xilogravuras, que permitiam a impressão conjunta com o texto ${ }^{16}$, surgem as iniciais xilografadas.

As tiragens variavam muito: quantidades pequenas como 100 a 150 exemplares não eram comuns (quase sempre para trabalhos encomendados ou de pouco interesse comercial); raramente se imprimiam menos de 300 exemplares; a tiragem média do período ficava entre 400 e 500 exemplares; mas alguns impressores foram além e se aventuraram em tiragens maiores, de 700, 1.025, 2.000 e 2.300 exemplares ${ }^{17}$. As quantidades estavam relacionadas com as condições de comercialização do impressor, pois as edições não eram destinadas apenas ao público local; representantes e vendedores ambulantes espalhavam as edições pela Europa.

As vendas se faziam gradativamente, e os impressores começaram adotar o uso de uma folha branca no inicio do texto e no final por proteção, assim a folha que se sujava não tinha texto; é por esta mesma razão que alguns livros tem o texto iniciando no verso da primeira folha.

\footnotetext{
${ }^{16}$ A gravura em metal exigia que fosse impressa separadamente, complicando demasiadamente o processo da produção do livro, mas existem livros ilustrados utilizando esta técnica.

${ }^{17}$ Esses números foram obtidos de documentos encontrados de algumas oficinas.
} 


\section{O Colecionador e sua biblioteca}

\subsection{O Colecionador}

Juan Carlos Reppucci nasceu em Bahía Blanca, Argentina, e é formado em engenharia civil. Vive em São Paulo desde junho de 1975, tendo adotado a cidadania brasileira em 1982.

No início da década de 1970 fez profundas amizades na Província de Entre Rios (Argentina), que se mantêm até hoje. As freqüentes reuniões dos amigos eram alegremente animadas por diferentes vinhos, e paulatinamente o tema vinário foi-lhe despertando entusiasmo e interesse.

Já no Brasil, nos anos finais de 1980, começou a comprar alguns livros sobre vinho, evidentemente novos e recém-publicados. Em dado momento, descobriu livrarias especializadas em livros antigos, tendo oportunidade de ver edições bem conservadas do século XIX. A partir daí, entre 1988 e 1990, decidiu pela formação de uma biblioteca vinária, passando a adquirir sistematicamente obras de qualquer época ligadas ao tema. Continua a acrescentar espécimes ao acervo, que está devidamente organizado em salas de seu escritório e registrado em banco de dados, que possibilita variadas consultas.

Garante Reppucci que o hobby de colecionar livros possibilitou-lhe ampliar o relacionamento com pessoas, em particular com grandes e experientes livreiros, de distintas partes do mundo: Argentina (Buenos Aires), Estados Unidos (costa leste e oeste), França (Paris, Beaune etc.) e Itália (Turim, Roma, Florença, Verona etc.). Com estes, a aproximação, que começa comercialmente, $\operatorname{logo}$ se converte em relacionamento amistoso de mútua confiança, quando não de amizade efetiva. A definição de preços, por exemplo, é sempre discutida com muita franqueza de ambas as partes, efetuando-se o pagamento depois do recebimento da obra.

Reppucci vê sua biblioteca com orgulho e preocupação: orgulho pela importância alcançada, já que seguramente se insere entre as dez mais importantes do mundo no tema; e com preocupação, porque ainda não desenvolveu idéia clara de como garantir continuidade à obra. A família o apóia, mas não há ninguém com a paixão necessária para continuá-la. 


\subsection{A biblioteca e o acervo de Incunábulos}

A BVR hoje possui aproximadamente 5000 itens, em sua maioria livros, mas contendo também manuscritos (livros e documentos), documentos impressos, periódicos, partituras, cardápios, catálogos e obras de referência.

\begin{tabular}{lrrrrrrrr}
\hline \multirow{2}{*}{ Itens do acervo } & \multicolumn{1}{c}{ Séculos } & \multirow{2}{*}{ Total } \\
\cline { 2 - 7 } & \multicolumn{1}{c}{ XV } & XVI & XVII & XVIII & XIX & \multicolumn{1}{c}{ XX } & \multicolumn{1}{c}{ XXI } & \\
\hline Livros impressos & 71 & 259 & 214 & 327 & 1431 & 2146 & 197 & 4645 \\
Documentos, partituras, periodicos, outros & & 1 & 5 & 89 & 30 & 50 & 12 & 187 \\
Livros e documentos manuscritos & 3 & 7 & 13 & 4 & 13 & 2 & 42 \\
\hline Total & 74 & 267 & 232 & 420 & 1474 & 2198 & 209 & 4874
\end{tabular}

Tabela 1- Distribuição das obras da BVR por séculos de acordo com os tipos de itens. (Dados de setembro/2008).

A importância da Coleção de Incunábulos da BVR é inegável, apesar da quantidade de incunábulos poder parecer, em um primeiro momento pequena, se comparada aos acervos estimados de grandes bibliotecas ${ }^{18}$ :

Bayerische Staatsbibliothek, Munique

British Library

Bibliothèque Nationale de France

Vatican Library

Oesterreichische Nationalbibliothek, Viena

Russian National Library, St Petersburg

Stuttgart Landesbibliothek

Huntington Library

Library of Congress

Bodleian Library

Russian State Library, Moscow

Cambridge University Library

John Rylands Library

Staatsbibliothek zu Berlin

Harvard University

Biblioteca Nacional, Madri

Yale University
18.550 incunábulos

12.500 incunábulos

12.000 incunábulos

8.000 incunábulos

8.000 incunábulos

7.000 incunábulos

7.000 incunábulos

5.600 incunábulos

5.600 incunábulos

5.500 incunábulos

5.300 incunábulos

4.600 incunábulos

4.500 incunábulos

4.400 incunábulos

3.600 incunábulos

3.300 incunábulos

3.525 incunábulos

\footnotetext{
${ }^{18}$ Conforme informações divulgadas nos respectivos sites.
} 
Koninklijke Bibliotheek

Stiftsbibliothek St. Gallen

University of Illinois at Urbana-Champaign
2.000 incunábulos

1.650 incunábulos

1.130 incunábulos

Mas é de se levar em conta que tais bibliotecas, além de públicas ou institucionais, têm séculos de existência e maiores recursos. Se atentarmos, porém, para outras, algumas também notáveis, a distância dos números se torna bem menor:

Biblioteca Nacional, Rio de Janeiro

Biblioteca Nacional de la Republica Argentina

Biblioteca Mário de Andrade, São Paulo

Bibliotecas da Universidade de São Paulo
216 incunábulos

21 incunábulos

9 incunábulos

1 incunábulo

Hoje a BVR possui setenta e dois incunábulos que trazem referência vinária, o que aumenta sua relevância. Lembre-se, também, que no período dos incunábulos (segunda metade do século XV), os textos religiosos eram a maioria, seguidos dos textos literários, jurídicos e, por último os científicos (cerca de 10\%). É claro que, nesse quadro, é pequena a incidência de textos impressos que se reportem à enologia.

A BVR encontra-se informatizada, através de programa desenvolvido especialmente para ela em Microsoft Acess. E, em princípio, não há restrição para que estudiosos, devidamente supervisionados, possam consultar o acervo - o que ocorreu, por sinal, para a execução deste catálogo.

Duas coleções afins à BVR, relacionadas ao vinho e à gastronomia, podem servir de parâmetro: a de André L. Simon (1877-1970) e a de Marcus e Elizabeth Crahan. A BVR também se aventura pela gastronomia, por ser tema correlato à enologia, não sendo rara a mescla dos dois temas.

André Simon não foi apenas bibliófilo e colecionador; publicou dezenas de livros sobre vinho e gastronomia, sendo que alguns se tornaram obras de referência nas áreas abordadas. Em sua Bibliotheca Bachica (SIMON, 1972), registra a 182 incunábulos; destes, apenas 41 estão assinalados com asterisco, indicando que fizeram parte de sua coleção particular até aquele momento. Entre os incunábulos da BVR, sete pertenceram a André Simon, trazendo inclusive seu ex-libris.

Em artigo para The Complet Imbiber 6, André Simon relata um pouco da história da sua coleção, da sua origem, de alguns livros importantes que adquiriu e de outros que nunca conseguiu. Com base nesse artigo e na Bibliotheca Bachica, pode-se reforçar a 
importância da BVR. Igual relevância tem o Catálogo da Coleção Crahan $^{19}$ (que incluía onze incunábulos) e a introdução escrita por Elizabeth Crahan.

Ambos destacam obras de suas coleções, como: De honesta voluptate de Platina (1475), Ruralium Commodorum de Crescentius (1471) e De re coquinaria de Appicius (1498). Com exceção da obra de Appicius, existente na BVR em edição de 1503, as outras duas obras estão presentes com exemplares das mesmas edições príncipes. Curiosamente, o incunábulo de Appicius, pertencente à coleção Crahan proveio de André Simon.

É constante a reflexão sobre a permanência dos acervos das bibliotecas formadas por particulares. Quantas não se formaram ao longo da história humana, e todavia quão poucas se conservaram incólumes, sem se dispersar! Felizmente há exceções, como o caso da preciosa Biblioteca Brasiliana do generoso Rubens Borba de Moraes ${ }^{20}$, a qual, acrescida de parte do acervo da Biblioteca Guita e José Mindlin, estará disponibilizada aos estudiosos, em prédio próprio que se levantará no campus da USP. Oxalá a BVR se inclua nessa exceção! De todo modo, antecipando-nos ao que determinará o destino, dedicamonos à confecção deste catálogo, que esperamos não só se transforme em fonte de referência, como os de Simon e Crahan, mas também acrescente novas informações aos estudiosos e interessados. $^{21}$

\section{O perfil do acervo}

Com sua rápida disseminação pela Europa, a imprensa possibilita primeiramente mais agilidade em relação ao trabalho que vinha sendo feito pelos copistas, mas logo a descoberta se mostra revolucionária, alterando definitivamente o processo de difusão do livro. O acesso antes assaz restrito do livro manuscrito ganha, com a nova tecnologia, força nunca antes imaginada de penetração e popularização.

Entretanto é importante ter em vista que, desde os primórdios, a produção estava diretamente relacionada com a demanda do mercado consumidor. Livreiros e impressores publicavam textos que julgavam de fácil comercialização e retorno relativamente rápido do

\footnotetext{
${ }^{19}$ Marcus and Elizabeth Crahan Collections of books on food, drink and related subjects. Nova York: Sotheby's, 1984.

${ }^{20}$ Bibliógrafo e historiador, autor entre outras obras, da imprescindível Bibliografia Brasiliana e de $O$ bibliófilo aprendiz.

${ }^{21}$ Pesquisando a procedência de exemplar da BVR (seguindo a pista de seu ex-libris), encontramos um artigo do New York Times que discute a temática dos herdeiros dos bibliólifos: "The children of book collectors", publicado em 12 de novembro de 1898. Cópia do artigo encontra-se nos anexos.
} 
investimento. Por esta razão os primeiros livros publicados foram, em geral, textos clássicos e religiosos, já bem sucedidos como manuscritos. Mas ainda no final do próprio século XV, os autores contemporâneos começam a ganhar espaço, como Hartamnn Schedel, Baptista de Salis, Nicolas Perottus ou Johannes Gritsch.

Entende-se, portanto, que são pouquíssimos os incunábulos exclusivamente sobre vinhos, de sorte que a BVR abrange obras de diversos assuntos, mas todas com abordagens mais ou menos extensas ao vinho, à vinha, à uva ou à embriaguez.

Assim, a biblioteca acolhe livros sobre religião, filosofia, literatura, história, medicina, agricultura e gastronomia, possuindo todos, sem exceção, apontamentos sobre sua temática, e formando um panorama cultural amplo, ao contrário do que faria supor o rigor e a restrição do assunto.

A agricultura, em especial a viticultura, está representada nos tratados mais importantes da antiguidade, como De re rustica, de Columela, que descreve com precisão as técnicas de cultivo da vinha, a produção do vinho e sua economia. Detalha desde a forma de se escolher o solo apropriado e sua influência para a qualidade dos vinhos, a distância em que se deve plantar uma videira da outra, até custos de estacas ou a quantidade de vinho produzida por um bom vinhedo romano. Também escreveram sobre agricultura e viticultura Catão, Varrão e Paládio, embora a contribuição de Columela seja a de maior relevância.

Historia naturalis de Plínio é a primeira enciclopédia da antiguidade, tratando de diversos assuntos. Nela Plínio dedica parte importante à viticultura, procurando fazê-lo de forma científica e ordenada. Descreve os tipos de uva, cultivo da vinha, e traz uma extensa lista das variedades e das diferentes procedências dos vinhos consumidos no Império Romano.

Completando os tratados de agricultura, já na Idade Média, temos Líber Commodorum Ruralium de Petrus de Crescentis, que faz uma releitura dos textos clássicos, como os de Columela e Plínio, aplicando-os a sua época.

Autores como Tito Lívio, Plutarco e Sêneca, não são considerados báquicos por Simon, mas suas narrativas históricas são testemunhos relevantes da importância do vinho na vida cotidiana na antiguidade. Na história universal de Hartmann Schedel, Líber Chronicarum, a vinha aparece ao lado de Noé em sua arca; há a presença de Baco e narrativas sobre a introdução do uso do vinho na Grécia e sobre a embriaguez. 
$\mathrm{Na}$ literatura, obras como as de Horácio, Ovídio e Marcial também são significativas: o vinho serve-lhes de inspiração, quando não de "combustível”, pois vários autores expressam sua paixão pela bebida. Ovídio, diz:

O vinho reanima os espíritos, faz o coração inflamar; o vinho bane e dissipa todas as inquietudes; então vem o riso; então o pobre se alegra e se imagina rico, as negras preocupações, as tristes lágrimas se dispersam, e os rostos se desanuviam. Então a alma se abre inteira, e a franqueza, tão rara nos nossos dias, toma o lugar da dissimulação banida pelo vinho". (Metamorfoses). ${ }^{22}$

Vale mencionar a obra de Beroaldus, uma sátira contra a embriaguez, a prostituição e o jogo. E a de Angelus Politianus, usada como obra de referência, que no capítulo Miscellaneorum centuria prima, listou os autores da antiguidade que discorreram sobre o tema do vinho.

$\mathrm{Na}$ medicina o uso do vinho como tratamento de diversos males é um consenso desde a antiguidade até a Idade Média e depois dela ainda. O clássico Regimen Sanitatis atribuído a Arnaldo de Vilanova, dedica-se à arte de viver bem e manter a saúde. Aconselha a prática de exercícios físicos e dá conselhos de higiene e boa alimentação. Destaca-se também por apresentar os nomes e as virtudes de diferentes vinhos, indicando quando e como bebê-los, e por falar sobre a temperança e a embriaguez. Vilanova era adepto da medicina dos humores e introduziu o álcool na medicina, através da aguardente, a que ele chamava de elixir da vida, tendo função de panacéia. Sua obra, Líber de vinis (não presente na BVR), é considerada a primeira obra sobre vinho (ver próximo tópico).

Bartolomeus Anglicus, médico e depois monge, tinha profunda admiração pelo vinho, que aparece em sua obra De proprietatibus rerum. Diversos capítulos são dedicados à vinha, à uva e ao vinho. Faz completa classificação dos vinhos, incluindo descrição quanto à cor e odor e conselhos de uso.

Outros autores escreveram sobre o uso do vinho na medicina ou para alcance de melhor qualidade de vida. Ficinus, médico florentino, considera a prevenção contra a peste uma das virtudes do vinho, e recomenda o uso de vários, de acordo com a idade e o temperamento do indivíduo. Avienus receita o vinho para dores de dente e indigestão.

De honesta voluptate et valetudine de Platina, é considerado o primeiro livro impresso sobre gastronomia. Possui diversas receitas e é também guia da arte de viver bem

\footnotetext{
${ }^{22}$ OVIDIO, apud SIMON, 1972, p. 33. (Trad. nossa).
} 
e dos prazeres da mesa. Quanto ao capítulo dedicado ao vinho, falta originalidade: ele se baseia em textos de autores clássicos, principalmente em Plínio. Mas declara: "que comer sem beber não somente perderá charme, mas será deplorável para a saúde”.

Já a obra Mensa philisophica atribuída a Theobaldus Anguilbertus, é um tratado sobre a alimentação sólida e líquida, que contém conselhos curiosos sobre o horário e o nome das refeições, as diferentes qualidades de certos vinhos e seus efeitos benéficos à saúde. Esta obra inaugura a gastronomia social, dá diretrizes para o comportamento à mesa, o uso do bom vinho e o conhecimento nutritivo dos alimentos.

Falemos agora da presença do vinho nos textos religiosos; conforme mencionado, o tema religioso foi dos mais publicados desde o nascer da tipografia, não sendo, pois, surpresa que na BVR tais textos sejam freqüentes.

A começar pela Bíblia Latina; como diz SIMON (1972), ela oferece um interesse capital do ponto de vista da sede humana. Toda a variação de vinhos, seu uso e seu abuso, são descritos em diversas passagens.

Johannes de Sanctus Geminiano cita em sua obra as passagens dos clássicos e das Sagradas Escrituras onde a vinha e o vinho figuram como sinônimos da fecundidade, da riqueza e da alegria. Enquanto Baptista de Salis enumera todos os tipos de pecados, incluindo a embriaguez.

Albertus Magnus no Líber de mulieri forti comenta o significado espiritual da vinha plantada pelo Senhor e do vinho representando o amor divino.

Quadrigesimale de Johannes Gritsch possui passagens sobre o vinho e a embriaguez, como estas: Vinum vendens mixtum aqua peccunt e Ebrietas an sit semper mortale peccatum.

Em geral, os textos religiosos, falam da embriaguez; Hugo de Prato Florido dedica todo um sermão à embriaguez: Luxuriosa res est vinum et tumultuosa Ebrietas. Os enfoques variam: alguns proíbem totalmente, já outros apenas aconselham a moderação. Vê-se, pois, que buscando inserir no acervo obras que contemplem o tema vinário, este "pequeno" conjunto de 72 incunábulos oferece um panorama amplo dos conhecimentos que o homem adquirira e das artes que praticara até o século XV, nas áreas da História, Filosofia, Poesia, Medicina, Ciências Naturais, Religião, Agricultura, Gastronomia... Ou seja, quem dispusesse desses exemplares em 1500, possuía verdadeira biblioteca em casa! 
Para reforçar esta assertiva, gostaríamos de ter podido dar maiores detalhes do conteúdo de cada obra; todavia, se de algumas, como a História Natural de Plínio, não faltam traduções e informações, de muitas outras há apenas informes genéricos; e estando redigidas em latim, não pudemos decifrá-las.

Atenuamos tal limitação criando dois itens, nos quais, a modo de palavras-chave ou descritores, indicamos os temas presentes em cada obra:

Assunto: agricultura, enciclopédia, filosofia, gastronomia, história, literatura, medicina, poesia, religião, vinicultura.

Interesse vinário: baco, embriaguez, gastronomia, história, história do vinho, mística do vinho, sobriedade, vinho como remédio, vinicultura, virtudes do vinho, viticultura.

Estes campos não tem a pretensão de serem perfeitos indexadores: eles seguem o perfil da coleção, e de seu proprietário, visando acima de tudo a praticidade e a simplicidade ao agrupar as obras mostrando sua razão de ser dentro do conjunto.

Outro aspecto relevante no acervo de incunábulos da BVR é a representação da arte tipográfica em seus diferentes aspectos, ou seja, considerando o livro como objeto, independentemente do seu conteúdo. Tem-se então rico cabedal de informes a respeito de assinatura, reclamo, registro, ilustração, tipologia, impressão em cores, encadernação de época, textos rubricados ou iluminados, impressores e suas marcas tipográficas, local de impressão.

Com base nos incunábulos deste catálogo, criamos a tabela geográfica (tabela 2) que nos fornece interessantes dados estatísticos, mostrando a produção tipográfica em diferentes países e cidades e, confirmando que a Itália (em particular Veneza), a partir da década de 1470, produzia mais livros que a própria Alemanha, onde a nova arte nascera. 


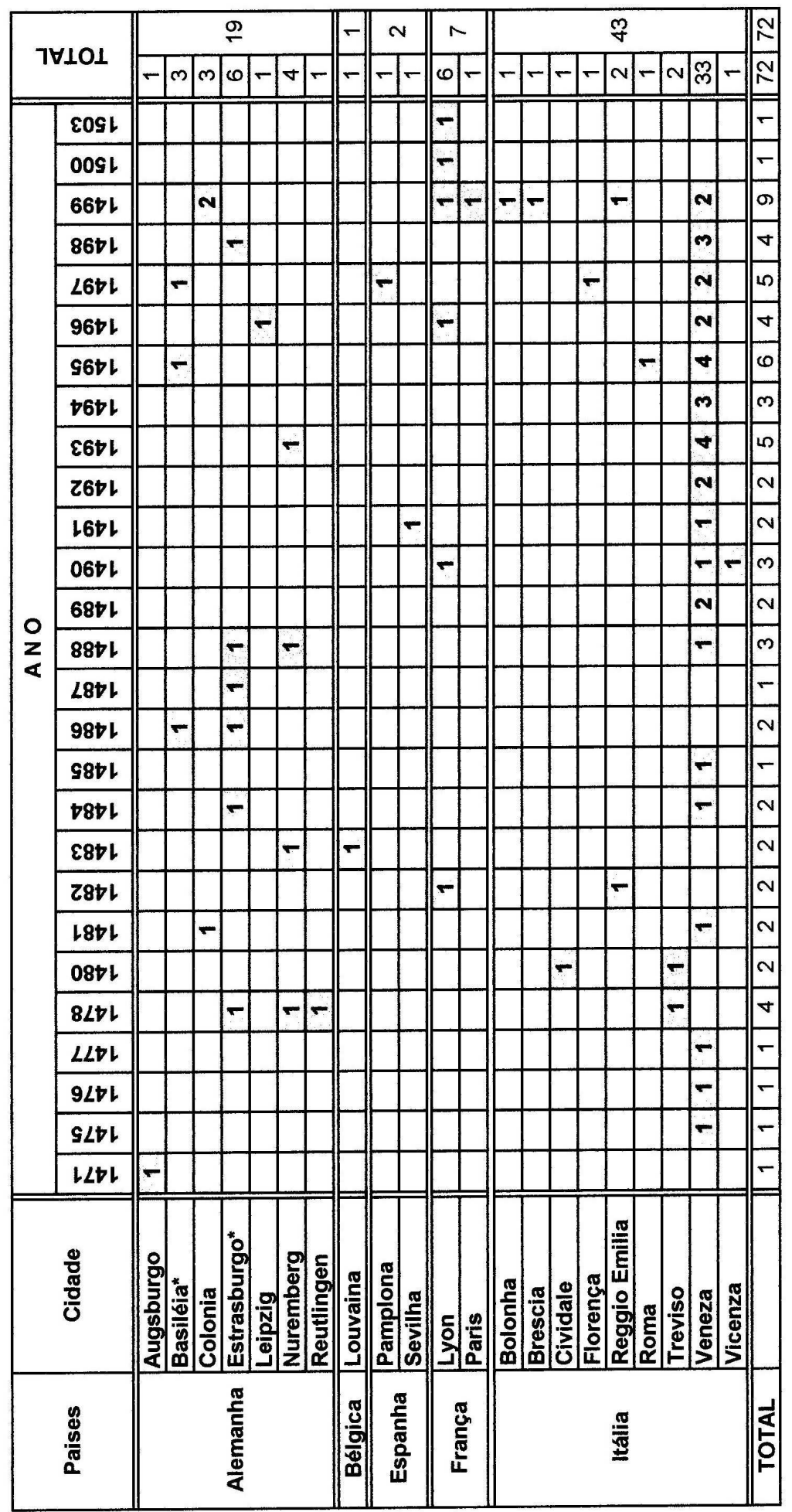

Tabela 2 - Tabela geográfica dos incunábulos da BVR:

relação de livros impressos por países e cidades através do século XV.

* Cidades pertencentes ao império alemão no século XV. 


\section{Processo de catalogação}

Além (como não poderia deixar de ser,) da análise exaustiva dos próprios incunábulos da BVR, a realização deste catálogo exigiu-nos grande intimidade com a incunabilística, obtida principalmente através do estudo de suas obras de referência e bancos de dados. Sem isso, teria sido impossível apresentar as características próprias de cada um dos itens do acervo.

Para adoção do formato aplicado nesta catalogação, utilizamos como base as normas da segunda edição do Código de Catalogação Anglo-Americano (AACR2), e, em casos omissos ou que não ficaram tão esclarecidos, as normas da International Standard Bibliographic Description for Older Monographic Publications (Antiquarian), (ISBD(A)) e Descriptive Cataloging of Rare Books (DCRB), por serem específicas para obras raras. Observaram-se também os critérios utilizados em outros catálogos e principalmente nos bancos de dados específicos de incunábulos (ISTC e GW).

A descrição de cada obra se fez conforme o modelo de ficha catalográfica desenvolvida neste trabalho, e nela podem se observar a distinção dos campos e os padrões estabelecidos para a apresentação.

O primeiro campo, em destaque, é o do $\mathbf{a n o}^{\mathbf{2 3}}$ de impressão da obra, pois define a organização adotada para o catálogo, que foi a ordem cronológica: dentro da cada ano, as obras estão dispostas em ordem alfabética de autor (responsabilidade). Para as obras cuja data é estimada, optou-se colocá-las após o último ano estimado. Ou seja, se a data suposta de publicação é entre os anos de 1491 e 1496, como em La vertu et proprietate des eaux artificielles, sua posição será após as obras impressas em 1496.

O campo seguinte, também em destaque, é a indicação de responsabilidade ${ }^{24}$, ou seja, a autoria da obra. O padrão definido para a entrada dos autores foi o latim, para internacionalizar o catálogo e em sequiência, datas de nascimento e morte do autor. As obras anônimas terão como entrada principal o título, e quando há atribuição, esta vem informada nas notas, bem como os pseudônimos.

\footnotetext{
${ }^{23} \mathrm{O}$ destaque aqui é feito para o nome dos campos que aparecem na ficha catalográfica adotada (tabela 3 ), e não por serem palevras presentes no glossário.

${ }^{24}$ Termos como indicação de responsabilidade, título uniforme e paralelo, são de uso especifico de catalogação bibliográfica, e não constam do glossário por terem seus significados e aplicações explicadas dentro do próprio texto.
} 


\section{ANO}

$\mathbf{N}^{\mathbf{o}}$

INDICAÇÃO DE RESPONSABILIDADE (datas biográficas)

Título uniforme $=$ Título paralelo

Indicação da edição.

Lugar de publicação : impressor(es), data de publicação.

Extensão do item : dimensões.

$\operatorname{Nota}(s)$ :

Informações complementares sobre título e responsabilidade.

Língua do texto; tradução e adaptação.

Informações complementares quanto à edição.

Assinatura.

Descrição física complementar.

Ilustrações.

Filigrana.

Procedência.

Conteúdo.

Detalhes do exemplar.

Assunto:

Interesse vinário:

Referências

Bancos de dados

Fac-símile eletrônico

Exemplares conhecidos

Outro(s) incunábulo(s) na BVR

$\mathbf{N}^{\circ}$ Tombo

Transcrição

Comentários.

Tabela 3 - Modelo da ficha catalográfica adotada. 
O título uniforme é aquele pelo qual a obra é normalmente conhecida e o título paralelo é o encontrado na obra, quando diferir do título uniforme. No caso dos incunábulos, a falta de folha de rosto, como conhecida hoje, faz com que as informações pertinentes para a catalogação encontrem-se em outras partes, como: página de abertura e colofão, introdução, apresentação ou prefácio.

O conceito de edição não existia no surgimento da imprensa, portanto não se encontra esta expressão nos incunábulos. Mas através de pesquisas em obras de referência e em bancos de dados, mencionaremos aqui as edições príncipes e as primeiras edições vernaculares.

O lugar de impressão e o(s) nome(s) do(s) impressor(es) são apresentados com seus nomes em português e a data de impressão expressa no calendário atual.

Extensão do item é a quantidade de folhas ou páginas e quantidade de volumes, quando houver. Dimensões é a altura do volume em centímetros, incluindo a encadernação; e entre parênteses, o formato (in fol., in $4^{\circ}$, in $8^{\circ}$, in $12^{\circ}$, etc.).

O campo Nota(s) contém os dados complementares quanto ao título e autoria, informações referentes à tradução, adaptação e comentários; colação completa da obra; ilustração, marca tipográfica e filigranas; sua procedência, finalizando com detalhes específicos do exemplar, como iluminuras, rubricas, anotações manuscritas e breve discrição da encadernação.

Os campos Assunto e Interesse vinário auxiliam no enquadramento da obra dentro da coleção. Conforme apresentado no ítem: o perfil do acervo.

Referências indica todas as referências bibliográficas consultadas e complementado com grande quantidade de referências encontradas em fontes secundárias.

Bancos de dados indica os códigos da obra encontrada em cada banco de dados; Fac-símile eletrônico registra o endereço na internet onde se encontra a reprodução facsímile da obra (quando existente).

Exemplares conhecidos apresenta a quantidade de exemplares encontrados em bibliotecas públicas e ou catálogos, acrescentando-se entre parênteses indicação do estado do exemplar (imperfeito, destruído, fragmento, pergaminho, vendido, perdido). Pareceunos de proveito acrescentar este campo que, a par de informar os exemplares sobreviventes, serve de indicativo (relativo) a respeito das tiragens. 
Outro(s) incunábulo(s) na BVR campo criado para indicar a existência de mais de um exemplar da mesma obra no conjunto; as informações contidas nos comentários sobre o autor e a obra aparecerem apenas na primeira ocorrência da obra.

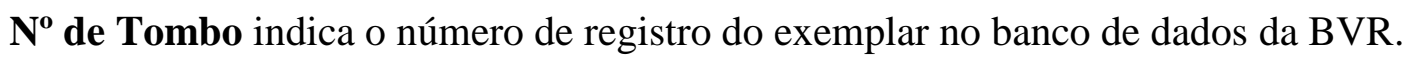

Transcrição é a cópia fiel de páginas ou trechos relevantes para a identificação da obra. $^{25}$

Em Comentários apresenta-se a obra em suas particularidades e elementos descritos sucintamente na catalogação desenvolvidos e detalhados, principalmente os elementos presentes nas notas.

Detalhes, nem sempre exclusivos dos incunábulos, são o diferencial para determinar a importância de uma edição (ou exemplar) em relação à outra(o). Por exemplo: o impressor; a presença de ilustrações ou comentários na edição; a procedência; anotações ou a encadernação de determinado exemplar. Outro exemplo são os exemplares cuja procedência é a Biblioteca de André L. Simon que merecem destaque por sua importância histórica, principalmente para os bibliófilos que colecionam obras sobre o vinho.

Essas características são úteis na identificação de data, impressor, cidade ou mesmo para autenticar uma obra. Nesse rol incluem-se os caracteres e as marcas dos impressores; tais informações, somadas àquelas contidas no colofão, nos reclamos e nas assinaturas, se convertem em subsídios para o estudo dos livros.

Por exemplo, Líber Chronicarum (1493), de Hartmann Schedel, é considerado um dos incunábulos mais importante pela quantidade e beleza de suas ilustrações; o exemplar da BVR possui algumas páginas pintadas à mão, e esta é uma particularidade que deve ser descrita, pois trata-se de possível diferencial entre este e os outros exemplares existentes. Por falar em ilustração, embora do conjunto de setenta e dois incunábulos poucos contenham ilustrações, mesmo assim julgamos que nos apresentam amostragem expressiva desse elemento no nascimento da imprensa.

Neste último campo também serão colocadas informações complementares sobre a edição, sobre os impressores de maior destaque, além de uma breve apresentação do autor, sua obra e sua inserção no acervo em razão da temática vinária.

\footnotetext{
${ }^{25}$ Por dificuldades na digitação alguns signos foram simplificados ou adaptados. Em eventual publicação deste catálogo, supriremos estas limitações.
} 


\section{Como entender o catálogo}

Nas intermináveis e extenuantes pesquisas feitas no desenrolar deste trabalho, valemo-nos de excelentes catálogos e bancos de dados (GW, ISTC, Hain, Proctor...). Para compreendê-los e deles extrair o máximo proveito, precisa o consulente, primeiro estar familiarizado com o assunto, e depois conhecer e dominar as inumeráveis abreviaturas e premissas estabelecidas pelos autores/criadores.

Seja por economia de espaço e conseqüente diminuição do meio que acolherá as informações, seja para dinamizar a leitura e desgastar menos o leitor, todo catálogo tem de valer-se desses recursos.

Não podendo nosso catálogo fugir a essa regra, por duas razões procuramos torná-lo o quanto possível legível ao maior número de leitores: primeiro pela quantidade pequena de suas entradas (no caso, 72 incunábulos) e segundo pelo propósito didático que buscamos.

Nesse sentido, acreditamos ter fornecido na introdução as informações que dêem ao consulente os conhecimentos suficientes a respeito dos incunábulos, matéria prima do catálogo; e reduzimos ao mínimo as abreviaturas nele empregadas e os pressupostos que nortearam sua feitura.

Abaixo apresentamos os pressupostos e nos ítens seguintes as abreviaturas adotadas e as das referências citadas.

Observações gerais:

- Toda informação que não consta da obra, mas é conhecida através de pesquisas realizadas e das obras de referência, é dada entre colchetes.

- Os nomes das cidades estão em português e as datas uniformizadas para o estilo atual; pode-se, porém, observar na transcrição a forma original em que aparecem na obra.

- Dada a impossibilidade de pesquisar a obra Typenrepertorium de Heabler, as informações encontradas em obras de referência sobre os tipos foram reproduzidas entre colchetes.

Para compreender a transcrição:

// indica mudança de linha no original.

O uso do itálico indica tratar-se de uma explicação complemantar.

Para as iniciais e seus espaços o número exponencial indica a altura equivalente do espaço em número de linhas, sendo que: 
$\left[{ }^{3}\right]$ equivale a espaço em branco reservado para inicial que deveria ser pintada (fig. a).

$\left(\mathrm{e}^{4}\right)$ espaço em branco reservado para inicial que deveria ser pintada com letra-guia impressa (fig. b).

( L xil. $^{6}$ ) espaço ocupado por inicial xilogravada (fig. c).

( $\mathrm{q} \mathrm{Q}^{3}$ ) espaço em branco reservado para inicial com letra-guia e letra pintada a mão, simples ou decorada (fig. d).

[ $\left.I^{7}\right]$ espaço em branco reservado para inicial que foi pintada a mão (fig. e).
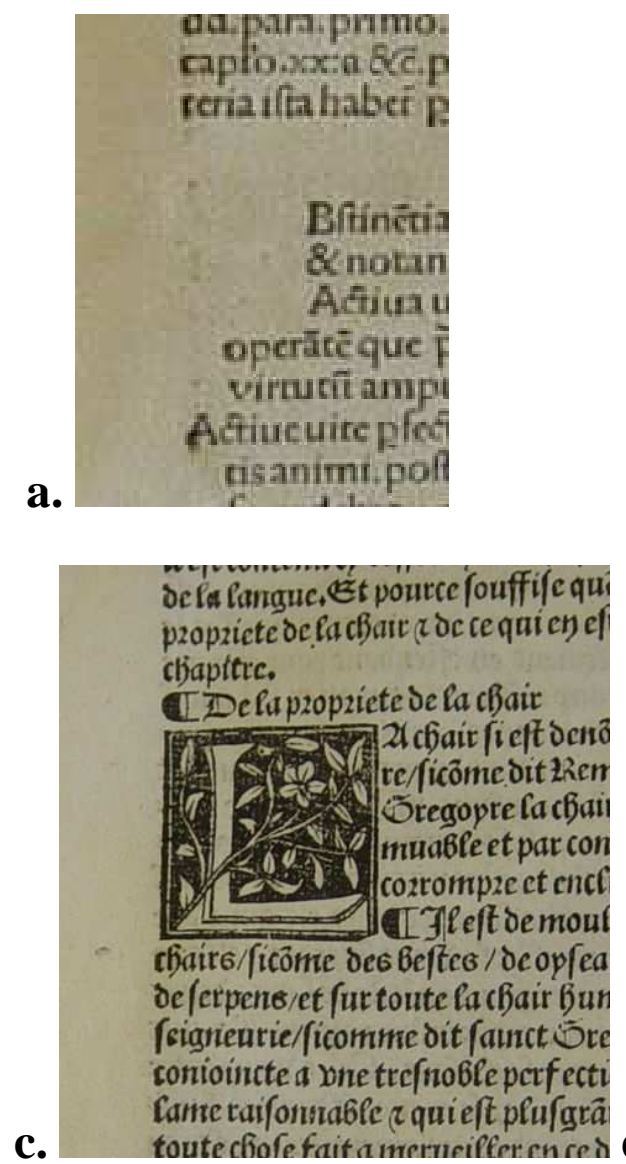

b.
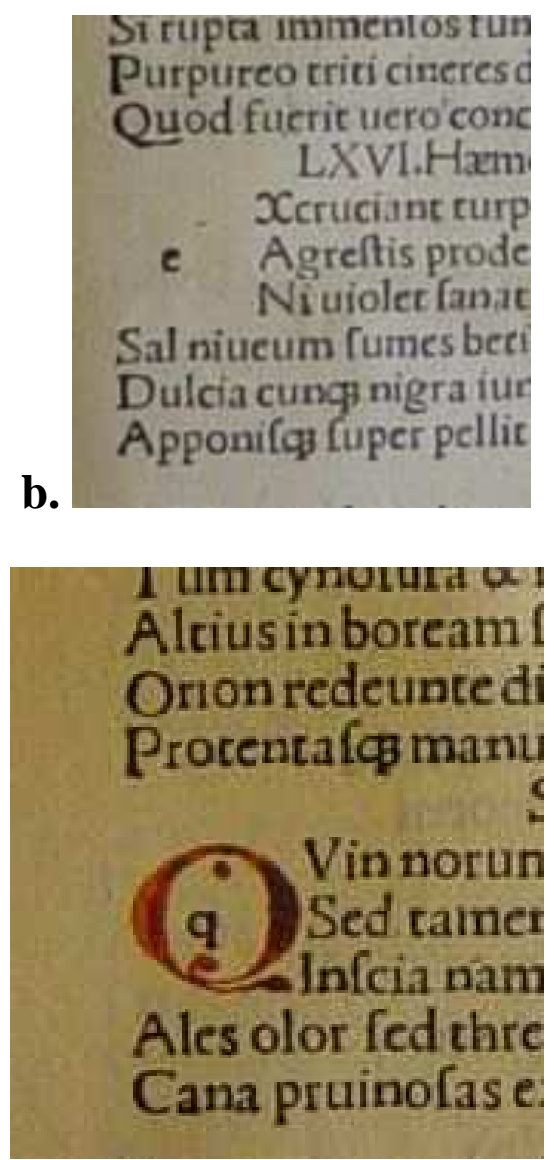

d.

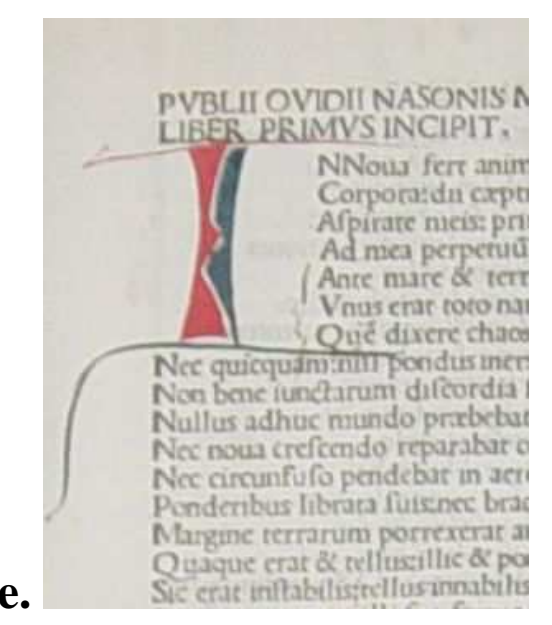




\subsection{Abreviaturas utilizadas}

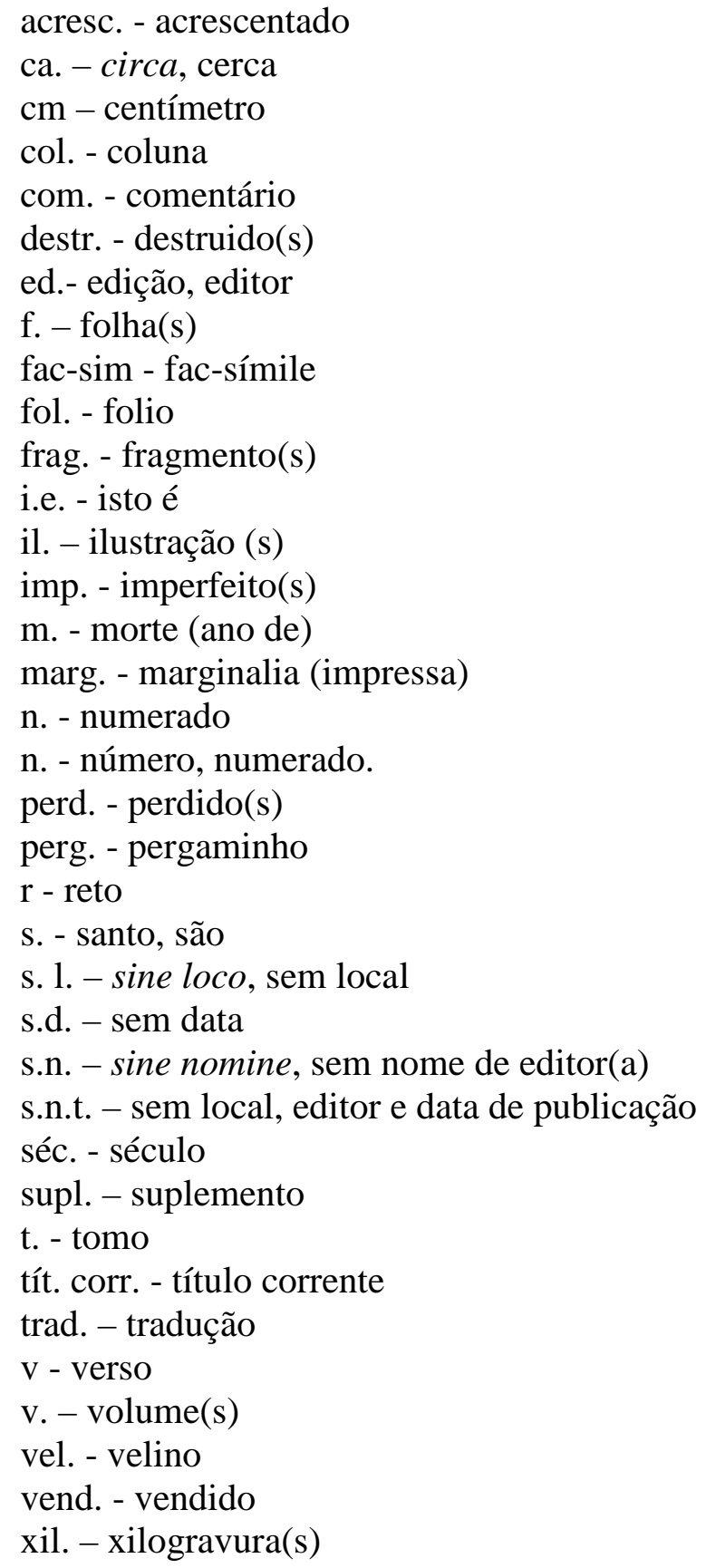




\subsection{Abreviaturas das referências citadas}

As obras assinaladas com * foram citadas através de fontes secundárias ${ }^{26}$, e não foram consultadas pela sua ausência em nossas bibliotecas. Achamos por bem incluí-las no trabalho, a fim de que as referências bibliográficas ficassem o mais completas possíveis.

\section{*Aquilon}

Aquilon, Pierre. Catalogues régionaux des incunables des Bibliothèques publiques de France. Volume X: Région Centre. Paris, 1991.

\section{*Arnoult}

Arnoult, Jean-Marie. Catalogues régionaux des incunables des Bibliothèques publiques de France. Volume I: Bibliothèques de la Région Champagne-Ardenne. Bordeaux, 1979.

\section{BInG}

Bagnasco, Orazio (Org.). Catalogo del Fondo Italiano e Latino delle opere di gastronomia - Sec XIV-XIX. Sorengo: Edizioni B.IN.G., 1994. 2 v.

*BMC

Catalogue of books printed in the XVth century, now in the British Museum. Lithographic reprint. London, The Trustees for the British Museum, 1963. 9v. (Facsimile da edição de Londres, 1908-1949).

\section{BN-RJ}

Catálogo de Incunábulos da Biblioteca Nacional. $2^{\text {a }}$ ed. Rio de Janeiro: Biblioteca Nacional, Departamento de Referência e Difusão, 1998.

\section{*Borm}

Borm, Wolfgang. Incunabula Guelferbytana: Blockbücher und Wiegendrucke der Herzog August Bibliothek Wolfenbüttel. Wiesbaden, 1990.

\section{Briquet}

Briquet, Charles Moïse. Les filigranes: dictionnaire historique des marques $\mathrm{du}$ papier dès leur apparition vers 1282 jusqu'en 1600. Mansfield Centre: Martino Publishing, 2005. 4 v. (Fac-simile da edição de 1907).

\section{Brunet}

Brunet, Jacques-Charles. Manuel du libraire et de l'amateur de livres... Berlim: Fraenkel \& Cie., 1921. 6 v.

\footnotetext{
${ }^{26}$ Principalmente do ISTC.
} 


\section{BSB-Ink}

Bayerische Staatsbibliothek Inkunabelkatalog. Bd. I [etc]. Wiesbaden, 1988- [em andamento].

BU

Bibliotheca Universitatis: Acervo Bibliográfico da Universidade de São Paulo. Séculos XV e XVI. São Paulo: Edusp; Imprensa Oficial, 2000.

\section{*Buffévent}

Buffévent, Béatrix de. Catalogues régionaux des incunables des Bibliothèques publiques de France. Volume VIII: Bibliothèques de la Région Ile-de-France. Paris, 1993.

$* \mathbf{C}$

Copinger, W.A. Supplement to Hain's Repertorium bibliographicum, Part II. 2 v. \& Addenda. London, 1898 \& 1902.

\section{*Camp}

Campbell, M.F.A.G. Annales de la typographie néerlandaise au XVe siècle. La Haye, 1874. - Campbell numbers between angled brackets are from the 10th supplement: L. and W. Hellinga. 'Additions and notes to Campbell's Annales and GW'. Beiträge zur Inkunabelkunde, Dritte Folge, 1 (1965) pp.76-86.

\section{*Campbell(Maps)}

Campbell, Tony. The earliest printed maps 1472 -1500. London, 1987.

\section{CCPB}

Catálogo Colectivo de Patrimonio Bibliográfico Español. Banco de dados. Disponível em: < http://www.mcu.es/bibliotecas/MC/CCPB/index.html> Acesso em: $31 / 08 / 2008$

\section{* CIBN}

Bibliothèque Nationale. Catalogue des incunables. Tome I fasc 1 (Xylographes et A); tome II (H-Z). Paris, 1981-92.

*CIH

Saja, Géza. Catalogus incunabulorum quae in Bibliothecis Publicis Hungariae asservantur. In colligenda matéria et identificandis incunabulis socii fuerunt Csaba Csapodi et Miklós Vértesy. Budapestini : In aedibus Academiae Scientiarum Hungaricae, 1970. 1 t. em 2 v.

\section{*Collijin}

Collijin, Isak. Katalog der Inkunabeln der Kgl. Bibliotheck in Stockholm. Stockolm: [s.n.], 1914. 
$* \operatorname{Coll}(S)$

Collijn, Isak. Katalog der Inkunabeln der Kgl. Bibliothek in Stockholm. 3 partes. Stockholm, 1914. (Nyförvärv 1915-1939 jämte tillägg. Kungl. Bibliotekets Handlingar, Bilagor 5. Uppsala, 1940.

$* \operatorname{Coll}(\mathbf{U})$

Collijn, Isak. Katalog der Inkunabeln der Kgl. Universitäts-Bibliothek zu Uppsala. Uppsala, 1907. (Bibliotheca Ekmaniana, 5)

*Deckert

Deckert, Helmut. Katalog der Inkunabeln der Sächsischen Landesbibliothek zu Dresden. 80. Beiheft zum ZfB. Leipzig, 1957.

*Delisle

Delisle, Léopold. Chantilly, Le Cabinet des livres: imprimés antérieurs au milieu du XVIe siècle. Paris, 1905.

\section{*Ernst(Hannover)}

Ernst, Konrad. Die Wiegendrucke des Kestner-Museums ... neu bearbeitet und ergänzt von Christian von Heusinger. Hannover, 1963.

\section{*Ernst(Hildesheim)}

Ernst, Konrad. Incunabula Hildesheimensia. 2 v. Hildeshemii, Lipsiae, 1908-09.

\section{*Essling}

Masséna, Victor, Prince d'Essling. Les livres à figures vénitiens de la fin du XVe siècle et du commencement du XVIe. 4 v. Florence, 1907-14.

\section{*Fernillot}

Fernillot, Yvonne. Catalogues régionaux des incunables des Bibliothèques publiques de France. Volume XII: Bibliothèque de la Sorbonne. Paris, 1995.

*Finger

Finger, Heinz. Universitäts- und Landesbibliothek Düsseldorf Inkunabelkatalog. Wiesbaden, 1994.

*GfT

Gesellschaft für Typenkunde des XV. Jahrhunderts. Veröffentlichungen. Leipzig.

\section{Gilhofer}

Gilhofer \& Ranschburg. Bibliotheca Mediiaevi: a fine collection of three hundred and twenty early printed books, 1465-1500. Catalogue 220. Viena, s.d. 


\section{*Girard}

Girard, Alain. Catalogues régionaux des incunables des Bibliothèques publiques de

France. Volume IV: Bibliothèques de la Région Basse-Normandie. Bordeaux, 1984. *Goff

Goff, Frederick Richmond. Incunabula in American Libraries: A third census of fifteenth-century books recorded in North American collections. New York: Kraus Reprint Co., 1973.

\section{Graesse}

Graesse, Jean George Théodore. Trésor de livres rares et précieux ou nouveau dictionnaire bibliographique. Cambridge: Maurizio Martino Publisher, [s.d.]. 8 v. em 4. fac-sim.

\section{*Günt(L)}

Günther, Otto. Die Wiegendrucke der Leipziger Sammlungen und der Herzoglichen Bibliothek in Altenburg. XXXV. Beiheft zum ZfB. Leipzig, 1909.

\section{GW}

Gesamtkatalog der Wiegendrucke; herausgegeben von der Komission für den Gesamtkatalog der Wiegendrucke... Banco de dados. Disponível em: <http://www.gesamtkatalogderwiegendrucke.de/NFuseEN.htm>.

\section{*Haeb(BI)}

Haebler, Konrad. Bibliografía ibérica del siglo XV. 2 partes. La Haya, Leipzig, 1903-17.

\section{Haebler}

Haebler, Conrado. Bibliografía Iberica del siglo XV: enumeración de todos los libros impresos en España y Portugal hasta el ano de 1500. Mansfield Centre: Martino Publishing, 2004. 2 v. em 1. fac-sim.

\section{Hain}

Hain, Ludovici. Repertorium bibliographicum, in quo libri omnes ab arte typographica inventa usque ad annum MD. Typis expressi ordine alphabetico.Vel simpliciter enumerantur vel adcuratius recensentur. Mansfield Centre: Martino Publishing, [2004]. fac-sim.

*HC

COPINGER, Walter Arthur. Supplement to Hain's repertorium bibliographicum or collections towards a new edition of that work. Milano: Görlich-Editore, 1950. 2v. 
*HC(Add)

Copinger, W.A. Supplement to Hain's Repertorium Bibliographicum, Addenda to Parte I. In: Copinger, W.A. Supplement to Hain's Repertorium... Parte II, v. 2, London, 1902.

*HCR

Reichling, Dietrich. Appendices ad Hainii-Copingeri Repertorium Bibliographicum... Emendationes. 6 v. e index. Monachii, 1905-11. (Supplement, Mona-terii, 1914.)

\section{Henssler}

Henssler, Maria Paleari. Bibliografia latino-italiana di gastronomia. Milano: Chimera Editora, 1998.

*Hillard

Hillard, Denise. Catalogues régionaux des incunables des Bibliothèques publiques de France. Volume VI: Bibliothèque Mazarine. Paris, Bordeaux, 1989.

\section{*Hubay(Augsburg)}

Hubay, Ilona. Incunabula der Staats- und Stadtbibliothek Augsburg. Wiesbaden, 1974.

\section{*Hubay(Eichstätt)}

Hubay, Ilona. Incunabula Eichstätter Bibliotheken. Wiesbaden, 1968.

\section{*Hubay(Ottobeuren)}

Hubay, Ilona. Incunabula in der Benediktinerabtei Ottobeuren. Wiesbaden, 1970.

\section{*Hubay(Würzburg)}

Hubay, Ilona. Incunabula der Universitätsbibliothek Würzburg. Wiesbaden, 1966.

\section{*Hummel-Wilhelmi}

Katalog der Inkunabeln in Bibliotheken der Diözese Rottenburg-Stuttgart. Bearbeitet von Heribert Hummel und Thomas Wilhelmi. Wiesbaden, 1993.

*IBE

Catálogo General de Incunables en Bibliotecas Españolas. Coord. y dir. por Francisco García Craviotto. Madrid, Dirección General del Libro y Bibliotecas, 1989-1990. 2v.

Bononos, Maria; Szandorowska, Elisa. Incunabula quae in Bibliothecis Poloniae asservantur $=$ Inkunabuly $\mathrm{w}$ Bibliotekach Polskich Centralny Katalog. Moderante Alodia Kawecka-Gryczowa. Wratislavia. Varsoviae. Cracoviae: Ex Officina 
Instituti Ossoliniani, 1970. 1t. em 2v. Precede ao título: Bibliotheca Nationalis Polona.

*IDL

Thienen, Gerard van. Incunabula in Dutch libraries: a census of fifteenth-century printed books in Dutch public collections. Nieuwkoop: De Graaf, 1983. 2v. (Bibliotheca Bibliographica Neerlandica; 17)

*IGI

Indice Generale degli Incunaboli della Biblioteche d'Italia. A cura del Centro Nazionale d'Informazioni Bibliografiche. Roma, La Libreria dello Stato, 19431981. 6v. (Ministero dell'Educazione Nazionale. Indici e cataloghi. Nouva Serie; I).

*ILC

Incunabula printed in the Low Countries. Edited by Gerard van Thienen \& John Goldfinch. Nieuwkoop, 1999.

ISTC

British Library. Incunabula short title catalogue. Banco de dados. Disponível em: <http://www.bl.uk/catalogues/istc/index.html>.

\section{*Jammes}

Jammes, Bruno. Catalogues régionaux des incunables des Bibliothèques publiques de France. Vol.VII: Bibliothèque de l'Institut de France, Bibliothèque Thiers. Paris, 1990.

*Klebs

Klebs, Arnold C. Incunabula scientifica et medica: short title list. Bruges, 1938. (Reprinted from Osiris, vol.IV.)

*Kurz

Kurz, Martin. Handbuch der iberischen Bilddrucke des 15. Jahrhunderts [Leipzig: Hiersemann, 1931].

\section{*Lefèvre}

Lefèvre, Martine. Catalogues régionaux des incunables des Bibliothèques publiques de France. Volume II: Bibliothèques de la région Languedoc-Roussillon. Bordeaux, 1981.

\section{*Louda}

Louda, Ji?í. Soupis prvotisk? Universitní knihovny v Olomouci a její pobo?ky v Krom??í?i. Praha, 1956. 
*Madsen

Madsen, Viktor. Katalog over det Kongelige Biblioteks inkunabler. 3 v. København, 1935-63. (P.R. Jørgensen. 'Nye inkunabler ...'. Fund og Forskning 30 (1991) pp. 133-38.)

*Mendes

Mendes, Maria Valentina C. A. Sul. Catálogo de incunábulos [Biblioteca Nacional, Lisboa]. Lisboa, 1988.

\section{*Mittler-Kind}

Mittler, Elmar and Kind, Helmut. Incunabula Gottingensia: Inkunabelkatalog der Niedersächsischen Staats- und Universitätsbibliothek Göttingen. Wiesbaden, 1995[em andamento].

\section{*Nentwig}

Nentwig, Heinrich. Die Wiegendrucke in der Stadtbibliothek zu Braunschweig. Wolfenbüttel, 1891.

*Neveu

Pellechet, Marie. Catalogue général des incunables des bibliothèques publiques de France. 3 v. Nendeln, 1970. (Posthumous section edited by M.-L. Polain. Reproduced from the copy of the original edition (Paris, 1897-1909) annotated by Polain). Ms 8538 (8424)

*Oates

Oates, J.C.T. A catalogue of the fifteenth-century printed books in the University Library Cambridge. Cambridge, 1954.

\section{Oberlé}

Oberlé, Gérard. Une Bibliotheque Bachique. Collection Kilian Fritsch. Catálogo de leilão. Paris: Loudmer, 1992.

\section{Oberlé (Fastes)}

Oberlé, Gérard. Les fastes de Bacchus et de Comus: histoire du boire et du manger en Europe, de l' antiquité a nos jours, a travers les livres. Catálogo de leilão. Paris: Belfond, 1898.

\section{*Ohly-Sack}

Ohly, Kurt and Sack, Vera. Inkunabelkatalog der Stadt- und Universitätsbibliothek und anderer öffentlicher Sammlungen in Frankfurt am Main. 5 v. Frankfurt, 196667. 


\section{*Osler}

Osler, Sir William. Incunabula medica: a study of the earliest printed medical books, 1467-80. Oxford, 1923.

\section{*Pad-Ink}

Hartig, Matthias [et al.]. Die Inkunabeln in der Erzbischöflichen Akademischen Bibliothek Paderborn. Wiesbaden, 1993.

\section{Palau}

Palau y Dulcet, Antonio. Manual del Librero Hispano-Americano. Madrid: Julio Ollero Editor, 1990. 7 v.

\section{*Parguez}

Parguez, Guy. Catalogues régionaux des incunables des Bibliothèques publiques de

France. Volume XI: Bibliothèques de la Région Rhône-Alpes I: Ain, Ardèche, Loire, Rhône. Paris, 1991.

\section{*Péligry}

Péligry, Christian. Catalogues régionaux des incunables des Bibliothèques publiques de France. Volume III: Bibliothèques de la Région Midi-Pyrénées. Bordeaux, 1982.

*Pell.

Pellechet, Marie Léontine Catherine. Catalogue général des incunables des bibliothèques publiques de France. Paris: Alphonse Picard et Fils, 1897.

\section{*Pell Ms}

Pellechet, Marie. Catalogue général des incunables des bibliothèques publiques de France. 3 v. Nendeln, 1970. (Posthumous section edited by M.-L. Polain. Reproduced from the copy of the original edition (Paris, 1897-1909) annotated by Polain).

\section{*Polain $(\mathbf{B})$}

Polain, M.-Louis. Catalogue des livres imprimés au quinzième siècle des bibliothèques de Belgique. 5 v. Bruxelles, 1932-78.

*Pol.

Polain, Louis. Catalogue des livres imprimés au quinzième siècle des bibliothèques de Belgique. Bruxelles: Société des Bibliophiles \& Iconophiles de Belgique, 1932. $4 \mathrm{v}$. 


\section{*Poynter}

Poynter, F.N.L. A catalogue of incunabula in the Wellcome Historical Medical Library. London, 1964.

\section{Proctor}

Proctor, Robert George Collier. An index to the early printed books in the British Museum. With notes of the those in the Bodleian library. London: K. Paul, Trench Trübner \& Co., 1898-1903.

\section{*Reichling}

Reichling, Dietrich. Appendices ad Hainii-Copingeri repertorivm bibliographicvm; additiones et emendationes edidit dietericvs Reichling... Monachii: Svmptibvs I. Rosenthal, 1905-1911. $7 \mathrm{v}$.

\section{*Renouard}

Renouard, Antoine Auguste. Annales de l'imprimerie des Alde, ou histoire des trois Manuce et de leurs éditions. Paris: Renouard, [1803]. 2 v. + suplemento.

*Riedl

Riedl, Mirko. Katalog prvotisk? jiho?eských knihoven. Praha, 1974.

\section{*Richard}

Richard, Hélène. Catalogues régionaux des incunables des Bibliothèques publiques de France. Volume XIV: Région Poitou Charente - Région Limousin. Paris, 1996.

\section{*Sack(Freiburg)}

Sack, Vera. Die Inkunabeln der Universitätsbibliothek und anderer öffentlicher Sammlungen in Freiburg im Breisgau und Umgebung. 3 v. Wiesbaden, 1985.

\section{*Sajó-Soltész}

Sajó, Géza and Soltész, Erszébet. Catalogus incunabulorum quae in bibliothecis publicis Hungariae asservantur. 2 v. Budapestini, 1970.

\section{*Sallander}

Sallander, Hans. Katalog der Inkunabeln der Kgl. Universitäts-Bibliothek zu Uppsala. 1) Neuerwerbungen seit dem Jahre 1907. Uppsala, 1953. (Bibliotheca Ekmaniana, 59). 2) Neuerwerbungen der Jahre 1954-64. Uppsala, 1965. (Bibliotheca Ekmaniana, 63).

\section{*Sander}

Sander, Max. Le livre à figures italien depuis 1467 jusqu'en 1530: essai de sa bibliographie et de son histoire. 6 vols. Milan, 1942. 


\section{*Schäfer}

Arnim, Manfred von. Katalog der Bibliothek Otto Schäfer, Schweinfurt. Teil I:

Drucke, Manuskripte und Einbande des 15. Jahrhunderts. Stuttgart, 1984.

\section{Scheler}

Thomas Scheler (Libraire). Incunables. Paris, abril de 1994. (Catálogo)

\section{*Schmitt}

Schmitt, Anneliese. 'Die Inkunabeln der Deutschen Staatsbibliothek zu Berlin im

Anschluss an Ernst Voulliéme. I) Katalog der in der Deutschen Staatsbibliothek zu

Berlin vorhandenen Inkunabeln. II) Die Inkunabeln der Preussischen Staatsbibliothek: Neuerwerbungen der Jahre 1927-45'. Beiträge zur Inkunabelkunde, Dritte Folge, 2 (1966).

*Schr

Schreiber, Wilhelm Ludwig. Manuel de l'amateur de la gravure sur bois et sur métal au $\mathrm{XV}^{\mathrm{e}}$ siècle. Tom. 5: Un catalogue des incunables à figures imprimés en Allemagne, en Suisse, en Autriche-Hongrie et Scandinavie. 2 partes. Leipzig, 191011.

\section{*Schramm}

Schramm, Albert. Der Bilderschmuck der Frühdrucke, fortgeführt von der Kommission für den Gesamtkatalog der Wiegendrucke. 23 v. Leipzig, 1920-43.

\section{*Sheppard}

Sheppard, L.A. Catalogue of XVth century books in the Bodleian Library. [Unpublished MS, 1954-71]

\section{Simon BBI}

Simon, André Louis. Bibliotheca bacchica: bibliographie raisonée des ouvrages imprimés avant 1600 et illustrant la soif humaine sous tous aspects, chez les peuples et dans tous les temps. London: The Holland Press, 1972. 2 v. em 1.

\section{*Torchet}

Torchet, Louis. Catalogues régionaux des incunables des Bibliothèques publiques de France. Volume V: Bibliothèques de la Région des Pays de la Loire. Bordeaux, 1987.

\section{*Veneziani(Brescia)}

Veneziani, Paolo. La tipografia a Brescia nel XV secolo. Firenze, 1986. (Biblioteca di bibliografia italiana, 107). 


\section{Vicaire}

Vicaire, Georges. Bibliographie gastronomique. Londres: Derek Verschoyle, 1954. *Vindel

Vindel, Francisco. El arte tipográfico en España durante el siglo XV. Pról. de Agustín G. de Amezúa. Madrid: Ministerio de Asuntos Exteriores. Dirección General de Relaciones Culturales, 1945-1954. 10v.

\section{*Voullième}

Voullième, Ernest Hermann. Die Inkunabeln der Königlichen Bibliothek und der anderen Berliner Sammlungen (Kunstgewerbemuseum, Kupferstich- kabinet, Universitä tsbibliothek, Graues Kloster, Joachimsthalsches Gymnasium usw.) Leipzig: O. Harrassowitz, 1906.

$* \operatorname{Voull}(\mathbf{B})$

Voulliéme, Ernst. Die Inkunabeln der Königlichen Bibliothek (Preussischen Staatsbibliothek) und der anderen Berliner Sammlungen. XXX. Beiheft zum ZfB. Leipzig, 1906. (Com três suplementos: 1914, 1922, 1927).

\section{*Voull(Bonn)}

Voulliéme, Ernst. Die Incunabeln der Königlichen Universitäts-Bibliothek zu Bonn. XIII. Beiheft zum ZfB. Leipzig, 1894.

$* \operatorname{Voull}(\mathbf{K})$

Voulliéme, Ernst. Der Buchdruck Kölns bis zum Ende des fünfzehnten Jahrhunderts. Bonn, 1903. (Gesellschaft fur Rheinische Geschichtskunde, XXIV).

\section{*Voull(Trier)}

Voulliéme, Ernst. Die Inkunabeln der öffentlichen Bibliothek und der kleineren Buchersammlungen der Stadt Trier. XXXVIII. Beiheft zum ZfB. Leipzig, 1910.

*Walsh

Walsh, James E. A catalogue of the fifteenth-century printed books in the Harvard University Library. 5 v. Binghamton NY, Tempe AZ, 1991-95.

\section{*Wilhelmi}

Wilhelmi, Thomas. Inkunabeln in Greifswalder Bibliotheken. Wiesbaden, 1997.

\section{*Zehnacker}

Zehnacker, Françoise. Catalogues régionaux des incunables des Bibliothèques publiques de France. Volume XIII: Région Alsace. Paris, 1997. 


\section{O Catálogo}

Na história do livro impresso o incunábulo ocupa o lugar de maior relevo, pois ele constitui não só uma peça de alto valor técnico como, em especial, uma peça do mais profundo significado artístico. Não há aí a ingenuidade um tanto rude do que viria a ser a literatura de cordel, mas antes uma arte equilibrada, ainda sem estar sujeita ao império comercial das grandes tiragens, como se verá já no séc. XVI, quando um Plantin, por exemplo, vem afirmar o reinado da grande indústria tipográfica, com a organização perfeita da sua importante oficina e com uma já bem diferenciada divisão de trabalho.

(McMURTRIE, 1969, p.298) 


\section{ca. 1471}

\section{1.}

CRESCENTIIS, Petrus de (ca.1230 - 1320)

\section{Ruralia commoda $=$ Líber ruralium commodorum libri duodecim .}

[Augsbourg] : Johann Schüssler, ca. 16 de fevereiro de 1471.

Edição Príncipe.

[209]f. ; 25,3 cm (in fol.).

Texto em latim.

35 linhas; caracteres góticos [tipos 1: 117G]; espaço para iniciais.

Filigranas: torre e letra "P".

Primeira folha com capitular decorada em azul e vermelho. Encadernação moderna em pleno couro com luva de proteção.

Assunto: Agricultura

Interesse vinário: Viticultura, vinicultura

Referências: Aquilon 246; B.In.G., p. 528-9; BMC, II, 328; Brunet II, 415; BSBInk C-695; CIBN C-667; CIH 1117, Delisle 570; Goff C-965 (+Supl.1972); Graesse II, p. 298; Günt(L) 91; Hain 5828*; Henssler, p.208; Hubay(Augsburg) 653; IBE, 1954; IBP, 1804; IDL, 1428; IGI 3260-A; Klebs 310.1; Oates 891; Parguez 362; Pell Ms 9327 (9150); Proctor 1590; Sack (Freiburg) 1190; Sajó-Soltész 117; Sheppard 1175, 1176; Simon BBI 32; Torchet 298; Voull(B) 53; Walsh 528.

Bancos de dados: CCPB 000109189-1; GW 07820; ISTC ic00965000.

Exemplares conhecidos: 57 (2 imp.).

Outros incunábulos na BVR: $n^{\circ} 21$ e nº 28

02703

Folha 1r: Petri de crefcentijs. Bononienfis // epiftola in librū comodorū ruralium. // $\left[\mathrm{U}^{8}\right]$ Enerabili in xpo patri $\cdot$ et domīo fpali viro // etc.

Folha 209r, linha 31: Petri de crefcentijs ciuis bonoñ · ruraliū Jmodorum libri duodecim // finiunt feliciter $\mathrm{p}$ iohannē Schù $l$ ler ciuem auguftenfen imprefli· // circit xiiij·kalendas 
marcias. Anno vero a partu virginis falutife- // ro Millefimo quadringentefimo et feptuagefimoprimo $\pi \dot{\mathrm{c}}$.

Folha 209v: branca

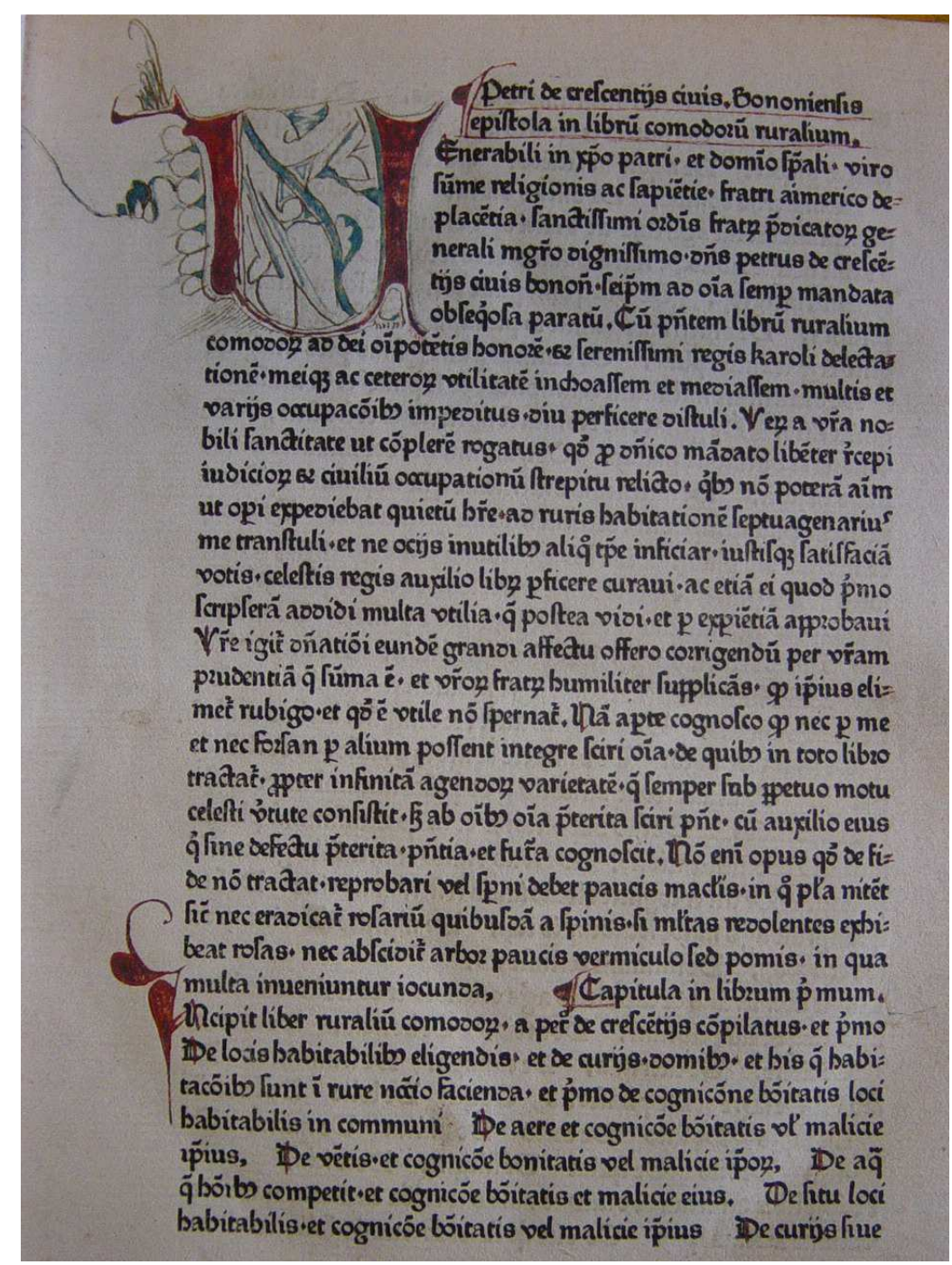

Fig. 1 - Reprodução da abertura do texto (f. 1r)

Encadernação em marroquino verde em estilo jansenista com cinco nervuras, filetes e fios fazendo molduras na lombada e nas capas, gravados a seco; apenas autor, título, cidade e data estão gravados em dourado na lombada. Os cortes são dourados e há uma bela moldura em dourado no interior das capas; encadernação assinada: Ateliers Laurenchet $^{27}$. Luva de proteção revestida com papel marmorizado igual ao das guardas. Pela cor do papel, muito branco, pode-se supor que na ocasião da encadernação a obra foi restaurada (suporte). A primeira página da obra apresenta inicial iluminada e rubricas em

${ }^{27}$ O ateliê de encadernação Laurenchet foi criado em 1947 por Henri Laurenchet e a partir de 1972 seus filhos assumiram a empresa que continua em atividade até hoje em Paris. 
vermelho; no restante da obra não há mais nenhuma decoração. O texto está completo, mas de acordo com as referências deveriam haver três folhas brancas no final da obra.

Natural de Bolonha, Petrus Crescentiis, estudou medicina e ciências naturais, e depois se tornou advogado; sua obra é considerada um dos principais tratados de agricultura do século XIV e talvez da Idade Média, tendo servido como material de referência por muito tempo e alcançando grande popularidade. Doze livros, cada um abrangendo um tema, formam esta enciclopédia; o Livro IV (De vitibus et vineis et cultu earum, ac natura et utilitate fructus ipsarum) é dedicado exclusivamente à vinha e ao vinho. 


\section{5}

\section{2.}

\section{PLATINA, Bartholomaeus (1421 - 1481)}

\section{De honesta voluptate et valetudine.}

Veneza : [Laurentius de Áquila e Sibyllinus Umber], 13 de junho de 1475.

[94]f. ; 27,0 cm (in fol.).

Texto em latim. O autor também é conhecido como Bartolomeo Sacchi (Simon cita como Jean Baptiste Platina ou Bartolomeus Sicci). A obra é didicada ao Cardeal B. Roverella.

Assinatura: [1?] $\left[\mathrm{a}^{4} \mathrm{~b}^{10} \mathrm{c}-\mathrm{l}^{8} \mathrm{~m}^{7}\right]$

32 linhas; caracteres romanos; espaço para iniciais.

Filigranas: cabeça de boi, balança

Procedência: "Joannis Baptista Cornely(?) \& amicorum" (inscrição manuscrita f.1r), "Medical Society of London" e "Withdrawn by The Wellcome Library" (carimbos f. 2v)

Exemplar com diversas anotações marginais por toda obra. Encadernação em pergaminho antiga, com lombada posterior em marroquino marrom aplicada sobre o pergaminho. Com caixa de conservação em tecido.

Assunto: Gastronomia

Interesse vinário: História do vinho

Referências: B.In.G., p. 1318-1320; Bitting, p. 373-374; BMC, V, 239 (IB20433) [s.t.]; Brunet, IV, p. 690; BSB-Ink P-560; CIBN P-438; CIH, 2767; Delisle 1481; GfT 2199; Goff, P-762 (+Supl. 1972); Graesse, V, p. 311; Hain, *13051; Hanssler, p. 581; IBE, 4652; IGI, 7848 e 7848 (var.) [=BMC]; Klebs 783.2; Madsen 3285; Pell Ms 9506 (9328); Proctor 4355; Sajó-Soltész 2767; Sheppard 3514, 3515; Simon BBI *78; Vicaire, p. 688; Voull(B) 3765; Walsh 1720.

Bancos de dados: CCPB 000111887-0; GW M33900; ISTC ip00762000.

Exemplares conhecidos: 61 (4 imp., 1 frag.).

Outros incunábulos na BVR: $\mathrm{n}^{\circ} 10$ e $\mathrm{n}^{\circ} 60$ 
Folha 1: branca (com diversas anotações e assinaturas manuscritas).

Folha $2 v$ : PLATYNAE DE HO- // NESTA VOLVPTATE // ET VALITVDINE LI- // BRI PRIMI CAPITA. // Deligendus locus ad habi- // tandum. // etc.

Folha 5v: (...) CAP. LIB. PLATYNAE // DE OBSONIIS ET Ho // NESTA VOLVPTATE // ET VALITVDINE FI. // VIRI DOCTISSIMI Pla // tynæ opufculum de obfo- // niis ac honefta uoluptate: // impreffum Venetiis Du- // ce iclyto Petru Mocenico. // Idibus. M cccclxxv.

Folha 6r: PLATYNAE DE HONESTA VOLVPTATE: // ET VALITVDINE AD AMPLISSIMVM AC // DOCTISSIMUM.D.B.ROVERELLAM.S.CLE // MENTIS PRAESBITER VM CARDINALEM // LIBER PRIMVS. // [ $\left.{ }^{4}\right]$ RRABVNT Et quidem etc.

Folha 94v: honeftatem: fanam mentē: \& bonam fpem amittentes // ab integra uoluptate: quam \& bonæ valitudini toniū- // ctam dicimus: cum dedecore declinabimus. // PLATYNAE DE OBSONIIS LIB. FIN.
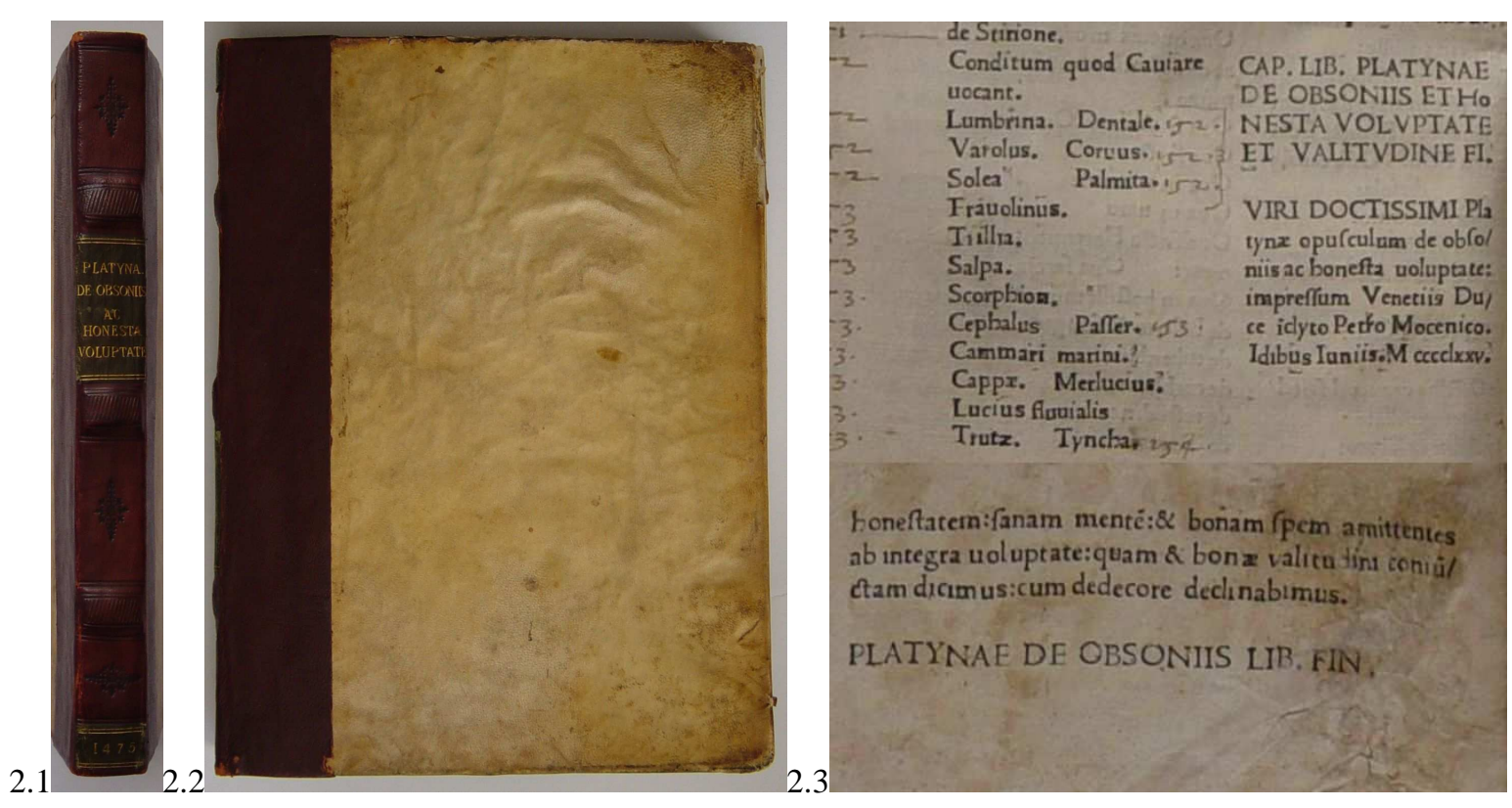

Fig. 2.1 e 2.2 - Detalhes da encadernação.

Fig. 2.3 - Detalhes do colofão (f. 5v) e da inscrição final (f. 94v)

Consta nas referências bibliográficas a presença de variações no colofão desta obra; em alguns exemplares são nove linhas, neste apenas seis. Nos exemplares cujo colofão tem nove linhas, consta o nome do impressor. A inscrição que aparece na folha 94v: "PLATYNAE DE OBSONIIS LIB. FIN", conforme Hain, também não de se encontram em todos exemplares; GW apresenta descrição com colofão igual a este (seis linhas) mas sem a inscrição. A folha branca inicial deve ter sido deslocada do fim, pois no último caderno 
falta uma folha (branca). Brunet e Simon descrevem exemplar com 94f., sendo última a branca.

A encadernação do século XVI em pergaminho sofreu intervenção ${ }^{28}$ e uma nova lombada em marroquino marrom foi aplicada sobre ela. Não há rubricas nem decoração, mas diversas anotações antigas manuscritas por toda obra.

Bartholomaeus Platina, humanista italiano também conhecido como Bartomoleo Sacchi, foi diretor da Biblioteca Vaticana; escreveu vários livros, mas notabilizou-se pela História dos Papas e por este pequeno tratado sobre a preparação dos alimentos e das bebidas. Há um capítulo que aborda o vinho (De vino), sem muita originalidade, como já dissemos, por se basear em textos clássicos.

De honesta voluptate et valetudine foi a primeira obra impressa sobre gastronomia e esta é a primeira edição datada; mas há outra edição ${ }^{29}$ sem indicação de data que pode ser a mais antiga. O livro alcançou grande sucesso no século XV e XVI (estima-se que foram publicadas em torno de vinte edições latinas e traduções até 1550), e em algumas edições o capitulo do vinho foi consideravelmente ampliado. Na BVR há outros exemplares da obra, entre eles o incunábulo número 10 deste catálogo.

\footnotetext{
${ }^{28}$ Neste caso não se pode considerar que a encadernação foi restaurada.

${ }^{29}$ [Rome, Ulrich Han, ca. 1475], referências: HC 13049; ReichlingApp. II, p.149; Proctor 3380.
} 


\section{6}

\section{3.}

\section{PLINIUS SECUNDUS, Caius (23 d.C. - 79 d.C.)}

\section{Historia naturalis.}

Veneza : Nicolaus Jenson, 1476.

[415]f. ; $31 \mathrm{~cm}$. (in fol.).

$1^{\mathrm{a}}$ ed. italiana

Texto em italiano, tradução do latim de Christophorus Landinus (1424-1492).

48-51 linhas; caracteres romanos.

Assinatura: $\left[\mathrm{a}-\mathrm{x}^{10} \mathrm{y}-\mathrm{z}^{8} \mathrm{~A}-\mathrm{C}^{8} \mathrm{D}-\mathrm{N}^{10} \mathrm{O}^{9} \mathrm{P}^{10}, \mathrm{Q}^{8} \mathrm{R}-\mathrm{S}^{10} \mathrm{~T}^{8} \mathrm{~V}^{10}\right.$ ]

Encadernação em pleno couro sobre pastas de madeira, do final do século XV ou inicio do XVI, decorada com filetes e florões dourados, fechos perdidos e pequeno restauros.

Assunto: Enciclopédia, história.

Interesse vinário: História do vinho, vinicultura, viticultura.

Referências: Arnoult 1215; B.In.G., p. 1334; BMC V, 176; Borm 2186; BSB-Ink P611; CIBN P-469 ; Goff, P-801 (+Supl. 1972); Graesse, V, p. 344; Hain *13105; Hensseler, p. 584; IBE, 4685; IGI,7893 (+Supl.); Jammes P-15 ; Klebs 787.1; Lefèvre 383; Mittler-Kind 502; Oates 1640; Oberlé (Fastes), p. 40; Osler(IM) 103; Pell Ms 9547; Proctor 4099; Schäfer 275; Sheppard 3272, 3273-4; Walsh 1583.

Banco de dados: GW M34342; ISTC ip00801000.

Exemplares conhecidos: 120 (18 imp., 1 frag., 8 vel.).

Outros incunábulos na BVR: $\mathrm{n}^{\circ} 12$ e $\mathrm{n}^{\circ} 66$

04416

Folha 1: branca

Folha 2r: HISTORIA NATVRALE DE.C.PLINIO SECONDO // TRADOCTA DI LINGVA LATINA IN FIORENTINA // PER CHRISTOPHORO LANDINO FIORENTINO // AL SERENISSIMO FERDINANDO RE DI NAPOLI. // PROHEMIO. // $\left(\mathrm{d}^{6}\right)$ I NESSVNA CHOSA SERENISSIMO ET INVIC- // tiflimo Re Ferdinādo etc. 
Prologo segue até folha $4 r$.

Folha 5v: branca

Folha 6r: LIBRO PRIMO DELLA NATVRALE HISTORIA DI.C. // PLINIO SECONDO TRADOCTA IN LINGVA FIOREN // TINA PER CHRISTOPHORO LANDINO FIORENTI // NO AL SERENISSIMO FERDINANDO RE DI NAPOLI. // PREFATIONE. $/ /\left(\mathrm{d}^{13}\right)$ ITERMINAI O GIOCONDISSIMO // imperadore con epiftola forfe di troppa licēntia // etc.

Folha 21v: branca

Folha $22 r$ : LIBRO SECONDO DELLA HISTORIA NATVRALE etc.

Folha 414v: OPVS NICOLAI IANSONIS GALLICI // IMPRESSVM // ANNO SALVTIS. M. CCCCLXXVI. // VENETIIS.

Folha 415: branca
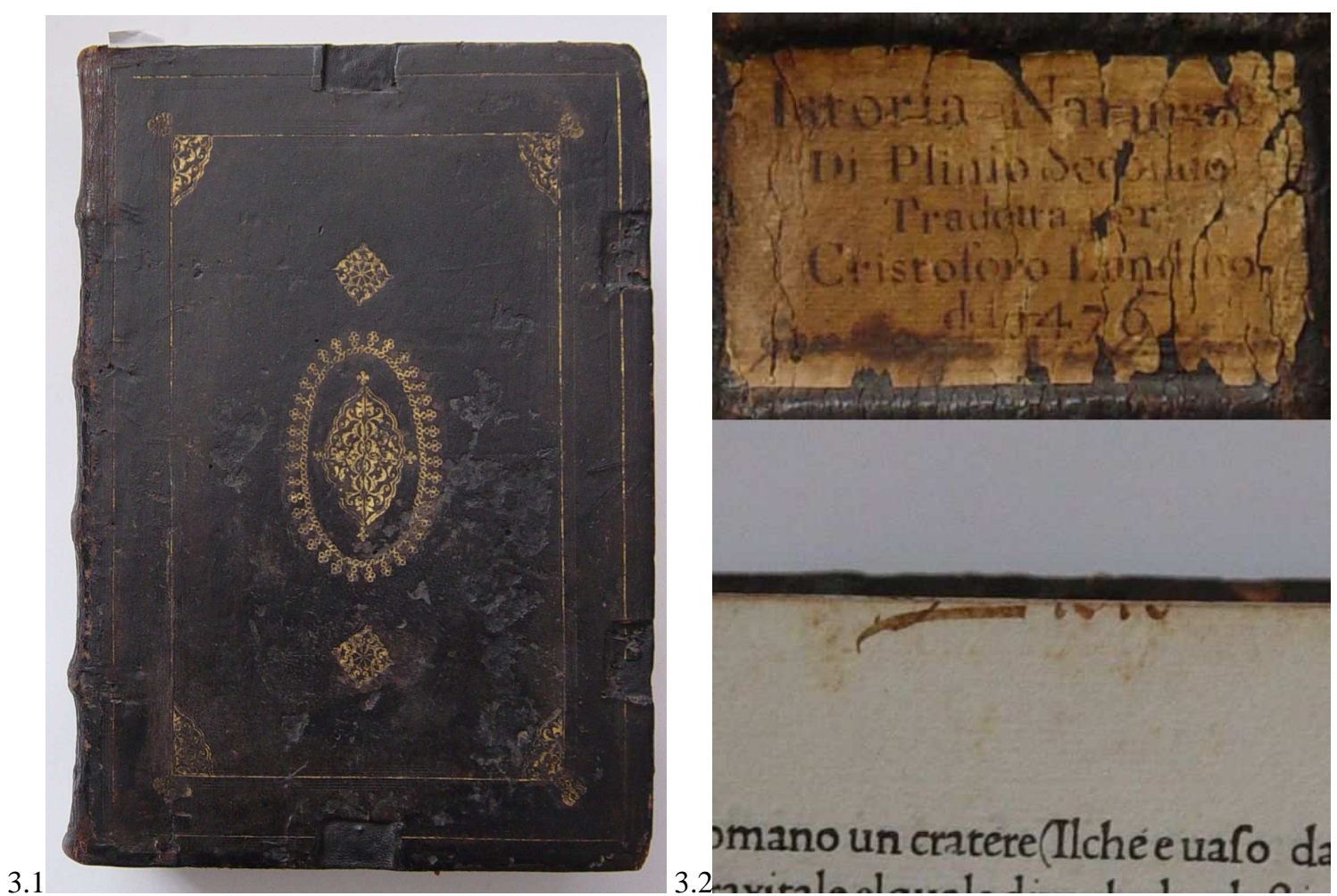

Fig. 3.1 - Detalhe da encadernação. Fig. 3.2 - Detalhes da etiqueta da lombada e inscrição manuscrita refilada.

Trata-se de um belo exemplo da encadernação veneziana do século XVI: em pleno couro sobre capas de madeira, decoração comgravação a ouro de fios e florões, fechos perdidos, quatro nervos salientes na lombada e etiqueta em papel (detalhe na ilustração). Apesar da encadernação ser da época e o miolo ter margens razoáveis, inscrições antigas na 
margem superior indicam que o exemplar provavelmente teve uma encadernação anterior com margens maiores e foi refilado, principalmente na cabeça (Fig. 3.2). O caderno com assinatura "O" possui nove folhas mas está completo, sendo um detalhe original da edição.

Nicolas Jenson, nasceu na França aproximadamente em 1420; com trinta anos começa a trabalhar na Casa da Moeda de Paris e em 1458 vai para Mongúcia para aprender a nova arte da impressão. Não desenvolveu seu trabalho na França, mas sua presença já é conhecida desde 1465 em Veneza (através de referências documentais), e seu trabalho de impressor inicia-se a partir de 1470, quando publica quatro livros com seus caracteres romanos, considerados obras primas até hoje. Sua oficina logo ganha destaque em Veneza, tornando-se uma das mais importantes, graças a sua capacidade técnica como tipográfo e suas habilidades administrativas e comerciais.

Plínio, o velho, foi historiador e naturalista romano, escreveu esta História Natural, que é uma enciclopédia dos conhecimentos científicos da Antiquidade e o primeiro livro impresso que trata detalhadamente da vinicultura.

O Livro XIV, divide-se em 22 capítulos, que versam sobre como cultivar uvas e produzir vinhos; desenvolvem temas como: condições climáticas; diferentes vinhos produzidos na Itália; como cuidar da adega; tipos de vinhos (branco, dourado, clarete e tinto). Graças a esta obra sabemos que os romanos conheciam bem a arte de fazer vinho, mesmo não contando com as preciosas conquista da química que hoje possuímos. 


\section{7}

\section{4.}

\section{GELLIUS, Aulus (ca. 125 -180 a.C.)}

\section{Noctes Atticaes.}

Veneza : Andreas [de Paltasichis] Catharensis, 1477.

[198]f. ; 31,5 cm (in fol.).

Texto em latim.

Assinaturas: $A-B^{8}, a^{10}, b-x^{8}, y-z^{6}$

36 linhas; caracteres romanos e gregos [tipos: 2:112R, 19:112Gr]; espaços para iniciais.

Filigrana: balança

Exemplar com grandes margens.

Encadernação antiga em papel (flexível), com lombada manuscrita.

Assunto: Literatura, História

Interesse vinário: História do vinho.

Referências: BMC, V, 251; Brunet, II, p. 1523; BSB-Ink G-64; CIH, 1380; GfT 2091; Goff, G-121; Graesse, III, p. 45; Hain, *7520; Hanssler, p. 334; IBE, 2596; IDL, 1904; IGI., 4189 (+Supl.); Klebs 442.4; Madsen 1667; Mittler-Kind 372; Ohly-Sack 1186; Parguez(Add) 5; Pell., 5011; Pol., 1559; Proctor 4423; Sajó-Soltész 1380; Sheppard 3556; Voull(B) 3814; Walsh 1744.

Banco de dados: CCPB 0001098313-4; GW 10596; ISTC ig00121000.

Exemplares conhecidos: 71 (4 imp.).

02955

Folha 1r: branca

Folha 1v: AVLI GELLI NOCTIVM ATTICARVM COMMENTARII // CAPITVLA PRIMI LIBRI. // [ ${ }^{2}$ ] Vali proportione: qbufq; collectionibus Plutarchus rōcinatū // effe Pythagorā ... etc.

Folha 17: branca

Folha $18 r$ (ass. $a_{i i}$ ): AVLI GELII NOCTIVM ATTICARVM COMMENTARII // LIBER PRIMVS. // $\left[\mathrm{P}^{6}\right]$ Lutarchus in libro etc. 
Folha 198r, linha 31: AVLI GELLI NOCTIVM ATTICARVM COMMENTARII // FINIS: IMPRESSI VENETIISPER ANDREAM IACOBI CA // THARENSEM. M.CCCCLXXVII. ANDREA VENDRA- // MENO DVCE VENETIARVM INCLYTO.
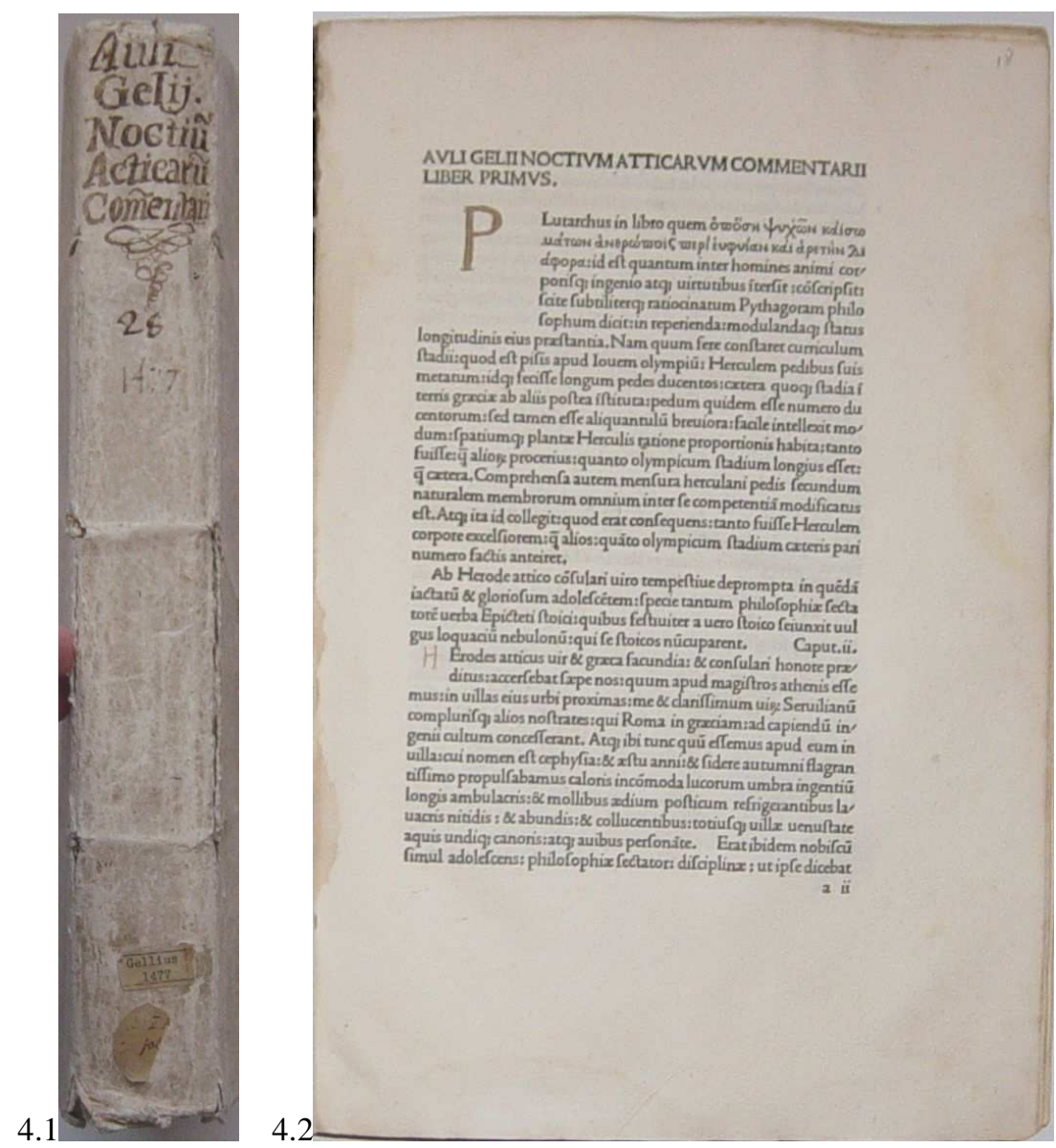

Fig. 4.1 - Detalhe da lombada da encadernação em papel com inscrição manuscrita.

Fig. 4.2 - Abertura do texto, Liber primus (f. 18r)

A obra possui encadernação italiana do século XVIII, flexivel em papel, costura feita sobre três nervos de couro ao alúmen que sustentam a capa. As primeiras folhas encontram-se mais sujas e desgastadas devido ao manuseio; presença de algumas manchas de umidade e buracos de inseto no final. De acordo com Hain e GW os cadernos com as asssinaturas A e B deveriam estar no final da obra cujo início se daria apartir da folha branca do caderno a (f. 17 deste exemplar).

Aulus Gellius autor e gramático latino do século II, possivelmente de origem africana, estudou gramática e retórica em Roma e filosofia em Atenas, retornando depois a Roma onde se dedicou a tratar de assuntos juridicos. Noctes Atticae, foi sua única obra, mas é de grande importância não só pela qualidade, mas por seus comentários e referências 
a autores antigos; de alguns autores, é tudo que restou; obra importante e rico material de estudo para as áreas de gramática, literatura, filosofia e histórica. O interesse vinário encontra-se em doze passagens sobre tipos de vinho, uso e costumes e o vinho na sociedade da época (vinum edormiant, vinum exoticum, vinum Rhodium Lesbium, vini tria genera etc.). 


\section{8}

\section{5.}

\section{HIERONYMUS, Eusebius Sophoronius - S. Jerônimo (ca. 342-420)}

Vitae sanctorum patrum, sive vitas patrum.

Nuremberg : Anton Koberger, 7 de maio de 1478.

I-CCXXXVIII, [7]f. ; $35 \mathrm{~cm}$ (in fol.)

Texto em latim. Acresc.: De laude et effectu virtutum. Pseudo-Macarius: Epistola ad monachos.

2 colunas; 51 linhas; caracteres góticos; espaço para iniciais.

Filigrana: uva, flor

Procedência: Doação de J. William Smith para a biblioteca pública de Syracuse, EUA (ex-libris) .

Exemplar com anotações manuscritas marginais. Impresso em preto com iniciais e parágrafos em vermelho. Encadernação do século XV (ou XVI) em pleno couro.

Assunto: Religião

Interesse vinário: Embriaguez

Referências: Aquilon 369; BMC, II, 416; Borm 2769; BSB-Ink V-250; CIBN H122; CIH, 1690; Goff, H-199; Coll(U) 714; Günt(L) 2003; HC, 8595; Hillard 1012; Hubay(Augsburg) 1047; Hummel-Wilhelmi 329; IBE 3171; IBP 2806; IDL 2314; IGI 4750; IJL 160; Madsen 4177, 4178; Nentwig 213; Oates 989, 990; Ohly-Sack 2983; Pell 11712; Pol., 3992; Proctor 1985; Sack(Freiburg) 3686; Sajó-Soltész 1690; Sheppard 1446, 1447; Torchet 460; Voull(B) 1654; Voull(Trier) 100; Walsh 676; Wilhelmi 317; Zehnacker 1164.

Banco de dados: CCPB 000110406-3; GW M50876; ISTC ih00199000.

Exemplares conhecidos: 108 (8 imp., 2 frag.).

Outros incunábulos na BVR: $\mathrm{n}^{\circ} 17$

Folha 1r: Prologus // Incipit plogus fancti hieronimi. // cardinalis. plbiteri: in libros Vitafpa // trum fācto $\pi$ Egiptio $\pi$. etiā eorū qui $\overline{1} / /$ etc. 
Folha 238v: 35 linhas // Anno xpi natiuitatis. Millefimoqdrin- // gētefimofeptuagefimooctauo. Nonas // ño Maj.ob beato $\pi$ pat $\pi$ profectū vita3 // heremiticā degentiū. gefta quo $\pi$ (haud // immerito) memoriter füt Jmendanda. // Opus (vitafpat $\pi$ appellatū) infigne. A P plurimis excerptū codicibo. p facrarū fcriptura $\pi$ viros admoduз pitiflimos: // ornatū. In oppido Nurnbergñ p Anto- // niū Coburger oppidi pfati incolā P cō// pte impreffum. Finit feliciter.

Folha 239: branca

Folha 240r: Texto manuscrito: "Codex monafterij fancti Marthie apoftoli. In quo rōti // netur. Opus. qd' vitafpatrū appelat ${ }^{2} . \overline{1}$ qtuor diftīctū ptes // Prima pars..." (índice)

Folha 240v: branca

Folha $241 r:\left[\mathrm{N}^{4}\right] \mathrm{E}$ occafione ftili hoc // $\overline{1}$ ope obtuati quilP legētiū aut // etc.

Folha 245v: $2^{a}$ coluna, final: Zophoronii $\mathrm{T}$ iohannis actus. fo.cxiij.C.

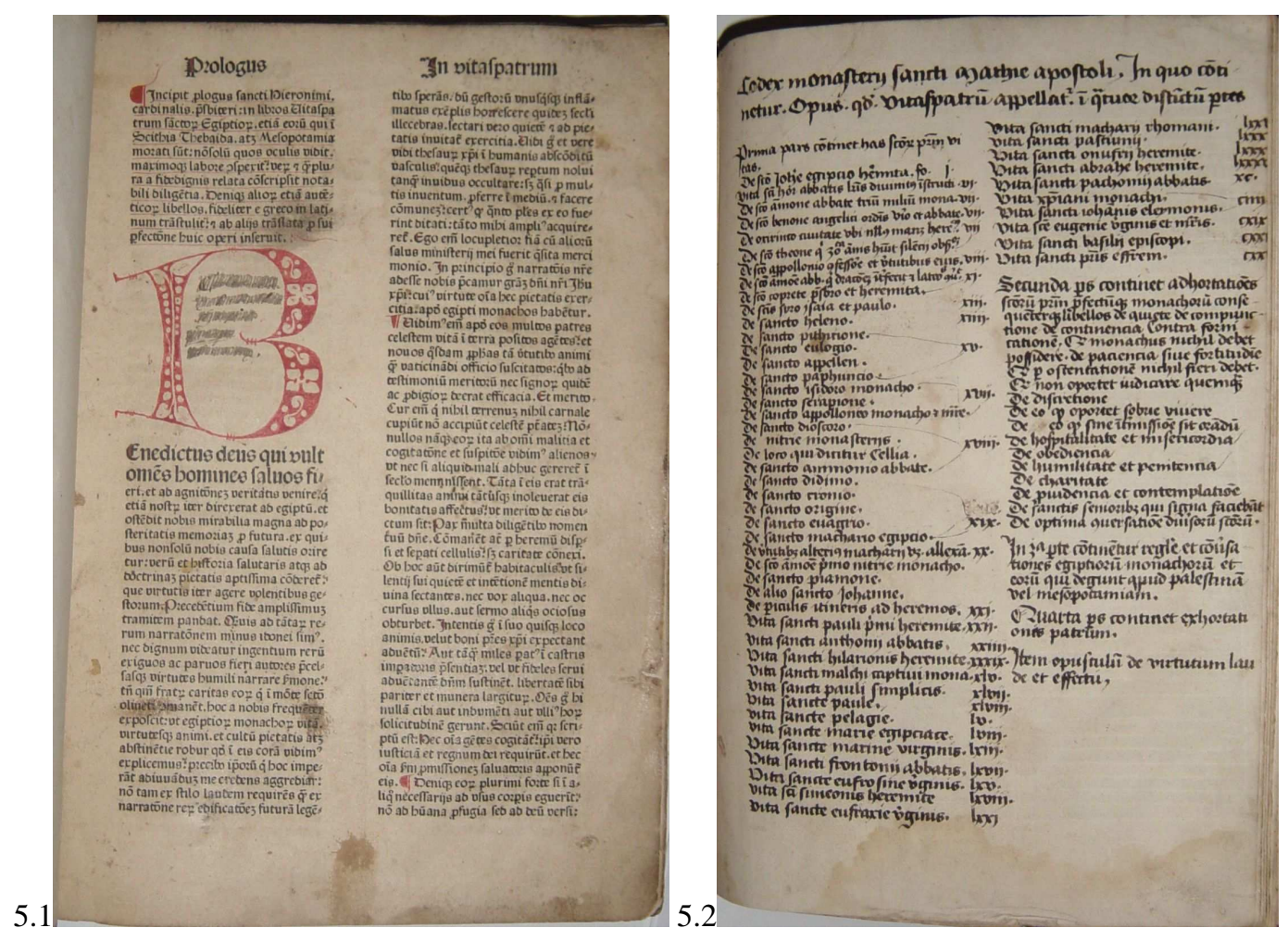

Fig. 5.1 e 5.2 - Detalhe da folha inicia (f. 1r) e da folha com índice manuscrito (f. 240r).

Encadernação em pleno couro do século XV ou inicio do XVI, com quatro nervos salientes e capa profusamente decorada com ferros a seco. Parágrafos e diversas iniciais pintadas a mão em vermelho e uma folha com índice manuscrito (f. 240r); apresenta algumas manchas de umidade e algumas anotações marginais. 
De acordo com as referências, as folhas da tábula, deveriam estar no início; e, provavelmente entre as folhas em branco e a manuscrita, apenas uma é original da obra (ou seja: [5], I-CCXXXVIII f.).

Anton Koberger (ca.1440/1445-1513) foi um dos mais importantes impressores do século XV; outros impressores podem tê-lo superado em quantidade, mas em relação à importância literária das obras que escolhia, da exelência da execução tipográfia e beleza de seus livros, provavelmente só foi igualado por Aldo Manuzio de Veneza (SOSA, p. 67), de quem se falará mais tarde nos cometários do incunábulo nº 61 deste catálogo. É de 1473 a primeira obra de Koberger com identificação impressa, mas estima-se que iniciou a atividade por volta de 1470. Antes de Vitae Sanctorum Patrum Koberger havia publicado cerca de trinta livros; até 1500 o total passou de duzentos livros impressos.

Depoimentos de contemporâneos e cartas mencionam o volume de trabalho desenvolvido pela oficina de Koberger (chegou a ter vinte e quatro prensas em atividade e cem funcionários, entre tipógrafos, prensistas, encadernadores e iluminadores); e tendo sua organização comercial representantes espalhados por diversas cidades européias para a venda de seus livros (normalmente os impressores dependiam do contato direto com os estudiosos interessados em suas edições).

Na coleção de incunábulos da BVR existem quatro obras de Anton Koberger, sendo a mais importante a edição em alemão das Crônicas de Nuremberg de 1493, considerada uma das mais impressionantes obras impressas durante século XV.

São Jerônimo, padre e doutor da Igreja católica, famoso sobretudo pela tradução da Bíblia para o latim, a chamada Vulgata. Em Vitae sanctorum patrum ele reconta a vida de alguns santos e o tema vinário é acidental em algumas passagens, como na que se lê vinum bibens convertit latrones (o bebedor de vinho converteu os ladrões). 


\section{6.}

\section{SENECA, Lucius Annaeus (4 a.C. - 65 d.C.)}

\section{Opera philosophica. Epistolae.}

Treviso : Bernardus de Colônia, 1478.

[212]f. ; $31,4 \mathrm{~cm}$ (in fol.).

Texto em latim. Edição de Blasius Romerus.

Asinatura: $a^{9} b-h^{8} i^{10} k-l^{8} m^{10} n-a a^{8} b b^{7}$

53 linhas; caracteres góticos.

Conteúdo: De remediis fortuitorum, De clementia, De beneficiis, De ira, De mundi gubernatione, De beata vita, De consolatione, De tranquillitate vitae, Quomodo in sapientem non cadit iniuria, De brevitate vitae, Epistolae ad Lucilium. De moribus. PseudoSeneca [Martinus Dumiensis, Arcebispo de Braga (Bracara)]: De quattuor virtutibus cardinalibus. Lucius Annaeus Seneca (o Velho): Declamationes, Suasoriae, Controversiae. Proverbia Senecae. Epistolae Pauli et Senecae

Exemplar rubricado em vermelho, encadernação moderna em pleno couro.

Assunto: Filosofia, literatura.

Interesse vinário: Embriaguez, história do vinho.

Referências: Arnoult 1310; BMC VI 892; Borm 2429; BSB-Ink S-266; CIBN S184; Coll(U) 134; Goff S369; HC 14591*; Hillard 1824; IBE 5190; IBP 4967; IDL 4084; IGI 8868; IJL 265; Madsen 366; Mittler-Kind 553; Oates 2461; Ohly-Sack 2545; Pell Ms 10392; Polain(B) 3481; Proctor 6484; Sack(Freiburg) 3199; Sajó-Soltész 3059; Sheppard 5517; Voull(B) 3606; Walsh 3311; Zehnacker 2092.

Banco de dados: CCPB 000112425-0; GW M41240; ISTC is 00369000.

Exemplares conhecidos: 149 (6 imp., 2 perd.).

Outros incunábulos na BVR: $\mathrm{n}^{\circ} 33$

02390

Folha $\operatorname{lr}$ (ass. $a_{2}$ ): Incipit Lucij Annei Senecæ cordubenfis liber de moribus: // in quo notabiliter $\mathrm{T}$ vitæ mores enarrat. // $\left[{ }^{10}\right]$ Mne peccatum actio. Acrio antem omnis voluntaria est: // tam bonesta q3 turpis ergo voluntarium estomne peccatum. // etc. 
Folha 212r, linha 20: Liber epiftolarum moraliflimi Seneæ // finit fœliciter. // etc. Linha 35: Impreffum Taruify per Bernardum de Colonia // Anno domini. M.cccc. 1xxviij.

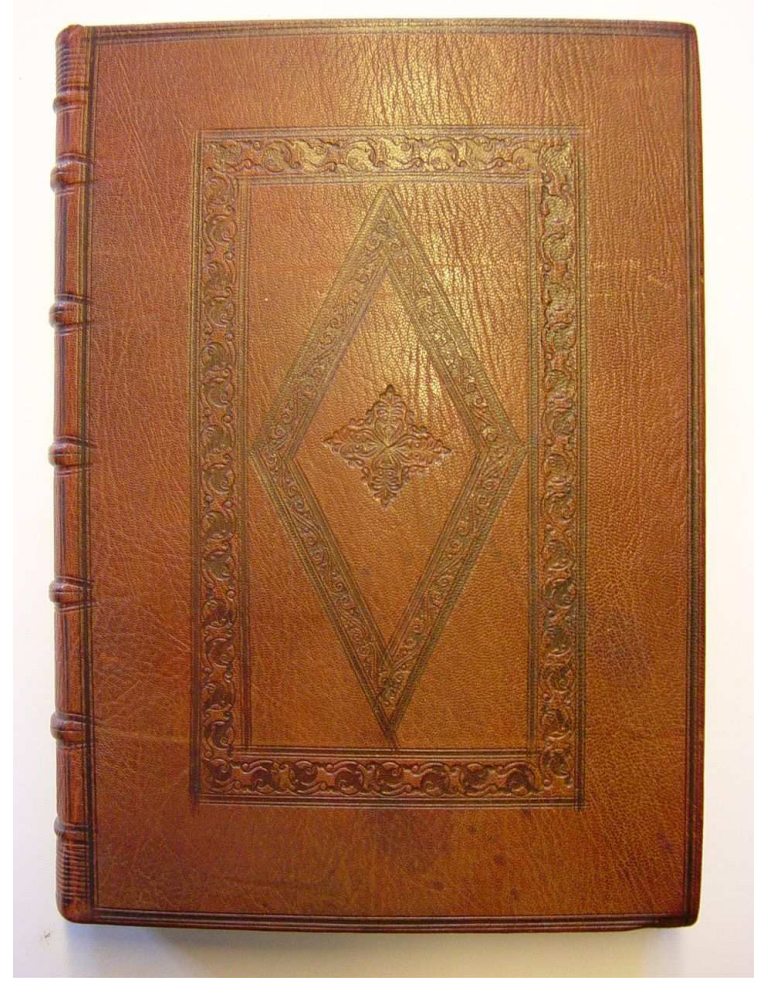

Fig. 6 - Detalhe da encadernação da obra de Seneca.

Exemplar com iniciais e parágrafos em vermelho, anotações manuscritas marginais por todo o livro, mas em geral bastante limpo. Encadernação moderna em pleno couro, sóbria, decorada com ferros gravados a seco em ambas as pastas e nervuras salientes. De acordo com as referências, a primeira e a última folha faltantes são brancas.

Lucius Annaeus Seneca, nasceu em Córdoba na Espanha, filho de um grande orador (Seneca, o Velho). Estudou em Roma oratória e filosofia, morou no Egito, voltando depois para Roma, onde se iniciou como orador e advogado, chegando ao Senado. Foi exilado na Córsega, quando escreve seus maiores tratados filosóficos. Voltou a Roma no ano de 49 e em 65 foi acusado por Nero de conspiração (conjuração de Pisão), suicidou-se no mesmo ano. Sua obra é constituida por tratados filosóficos e de moral, sátiras e tragédias.

No Livro IV consagra o último capítulo ao uso da neve para refrescar o vinho, costume muito difundido em seu tempo, mas do qual ele não era partidario. Diz que eram sobretudo os vinhos velhos e fortes que se serviam resfriados, e em uma das cartas escreve: "nos vinhos velhos encontramos um amargo que nos agrada". 


\section{[não depois de 1478]}

\section{7.}

HUGO DE PRATO FLORIDO (ca. 1262-1322)

Sermones dominicales super evangelia et epistolas = Sermones de tempore.

[Estrasburgo : Georg Husner, não depois de 1478].

[477]f. ; $32 \mathrm{~cm}$ (in fol.).

Texto em latim.

1 e 2 colunas; 40-42 linhas; caracteres góticos [tipos: 3:100G, 4:100G].

Filigranas: cabeça de boi, castelo ou torre.

Iniciais pintadas a mão e uma página iluminada. Encadernação moderna com lombada em couro.

Assunto: Religião

Interesse vinário: Embriaguez

Referências: BMC I 85; BSB-Ink H-412; Goff H-506; Günt(L) 2845b; Hain 8997*; Hubay(Augsburg) 1082; Hummel-Wilhelmi 631; IBP 5752; IDL 2410; Madsen 2040; Mendes 616; Ohly-Sack 1508; Pad-Ink 363， 364; Polain(B) 2016; Proctor 364; Sack(Freiburg) 1902; Sajó-Soltész 1749; Sallander 2251; Voull(B) 2204,2; Voull(Trier)1363; Walsh 126.

Banco de dados: GW n0218; ISTC ih00506000.

Exemplares conhecidos: 56 (15 imp., 1 frag., 1 perd., 2 destr.).

02956

Folha $1 r:\left[\mathrm{A}^{5}\right]$ Braam patrem no // ftrum imitari debe // mus in octo maxi // etc. Tabela segue até folha $9 v$.

Folha 10r: Incipiunt fermones dominicales fuper euangelia et epi // ftolas per totum annum editi a fratre hugone de prato // ordinis predicatorum. // Prologus // $\left[\mathbb{E}^{8}\right]$ Cce davit voci fue vocem virtutis os. // etc.

Folha 477r: (...) Explitiūt fermones dñicales fup evāgelia et epïas p totum an // nū fratis hugonis de prato ordinis pdicato $\pi$. 

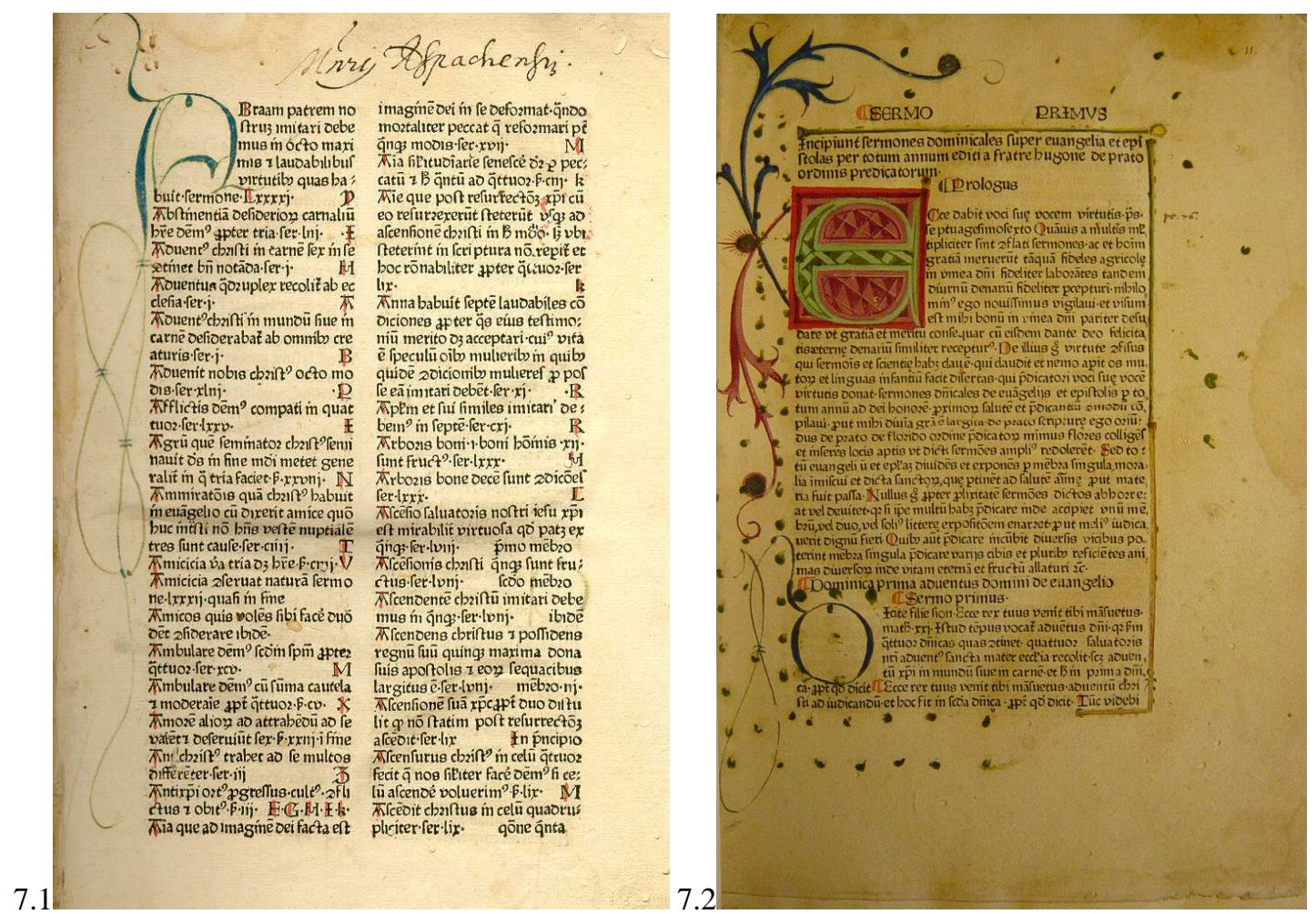

Fig. 7.1 e 7.2 - Página de abertura da obra (f. 1r) e abertura dos sermões (f. 10r).

Sermones Dominicales possui duas páginas decoradas, algumas iniciais e a marcação dos parágrafos em vermelho. Pode-se observar nas imagens acima, que a primeira folha (esquerda) possui uma inicial simples, parecendo que o trabalho de decoração não se completou.

A encadernação é moderna com lombada em marroquino marrom e pastas revestidas em tecido, com nervuras salientes e douração apenas de autor, título e data na lombada; foi realizada apenas com a intenção de embelezar o livro, mas a abertura da folhas está comprometida por uma estrutura inadequada. A substituição da encadernação atual por outra de conservação está sendo considerada.

Hugo de Prato Florido foi um religioso dominicano de Florença, de origem ilustre e alcançou sucesso e reconhecimento por suas pregações eloquentes. Seus sermões já eram procurados entre os manuscritos (a partir do final do século XIII), continuando com o surgimento da imprensa, que investe primeiro em obras que reconhecidas. A primeira é de 1476 e esta (que não é posterior a 1478) já é a quarta.

Sermones Dominicales é uma coletânea de sermões; o segundo é dedicado ao vinho e aà embriaguez; trata dos beneficios de beber com moderação e dos prejuízos do excesso e da bebedeira. $\mathrm{O}$ tema se estende por aproximadamente oito folhas, fato não usual em obras religiosas, o que realça a importância da obra dentro da coleção. 


\section{8.}

\section{NIDER, Johannes (ca. 1380-1438)}

\section{Preceptorium divinae legis, sive expositio decalogi.}

[Reutlingen : Michael Greyff, não depois de 1478] , [ca. 1475].

[299]f. ; 30,0 cm (in fol.)

Texto em latim

Assinatura: $\left[A^{10} b-c^{8} d^{12} e^{10} f-g^{8} h^{10} i^{8} k^{10} l^{8} m^{10} n-o^{8} p^{10} q-r^{8} s^{10} t^{8} u^{10} x^{8} y^{10} z^{8} A^{10}\right.$ $\left.\mathrm{B}^{8} \mathrm{C}^{10} \mathrm{D}^{8} \mathrm{E}-\mathrm{F}^{10} \mathrm{G}^{8} \mathrm{H}-\mathrm{K}^{10}\right]$

2 colunas; 39-42 linhas, título corrente; caracteres góticos redondo.

Filigrana: cabeça de boi.

Encadernação do século XV-XVI em pleno couro.

Assunto: Religião

Interesse vinário: Sobriedade.

Referências: BMC II 576; BSB-Ink N-164; Goff N203; HC 11781*; Hubay (Ottobeuren) 314; Hummel-Wilhelmi 467; IBP 3989; IDL 3398; Madsen 2913; Neveu 451; Ohly-Sack 2140; Pad-Ink 514; Polain(B) 2873; Proctor 2684; Sack(Freiburg) 2587, 2588; Sheppard 1946; Voull(B) 1968; Voull(Trier) 1175.

Banco de dados: GW26937; ISTC in00203000.

Exemplares conhecidos: 47 (1 imp., 2 frag.).

Fac-símile eletrônico disponível em Verteilte digitale Inkunabelbibliothek: <http://inkunabeln.ub.uni-koeln.de/vdib-info/kleioc/in00203000>.

00012

Folha 1r: [ ${ }^{5}$ ]Borfus caufe que // fint v. p. ca.j. E cir // ca mediū et quale // etc. Tab. Expl. Segue atéf. $25 \mathrm{v}$

Folha 25v: coluna 2: (...) Et fic eft finis.

Folha 26r: Incipit prologus in expo // fitionem decalogi $\mathrm{fm}$ fra- // trem Iohannem Nider fa// cre theologie profeflorem // ordinis predicatorum // [ ${ }^{8}$ ]ECALOGI // legem facra // tiflimam pri // etc.

Folha 299r, coluna 2: (...) Iohannis nider facre paginis // Egregii doctoris ordinis pdi- // catorum. Conuentualis nurē // bergēfis pceptorii p clariflimū // opus Finit feliciter. 
Folha 299v: branca

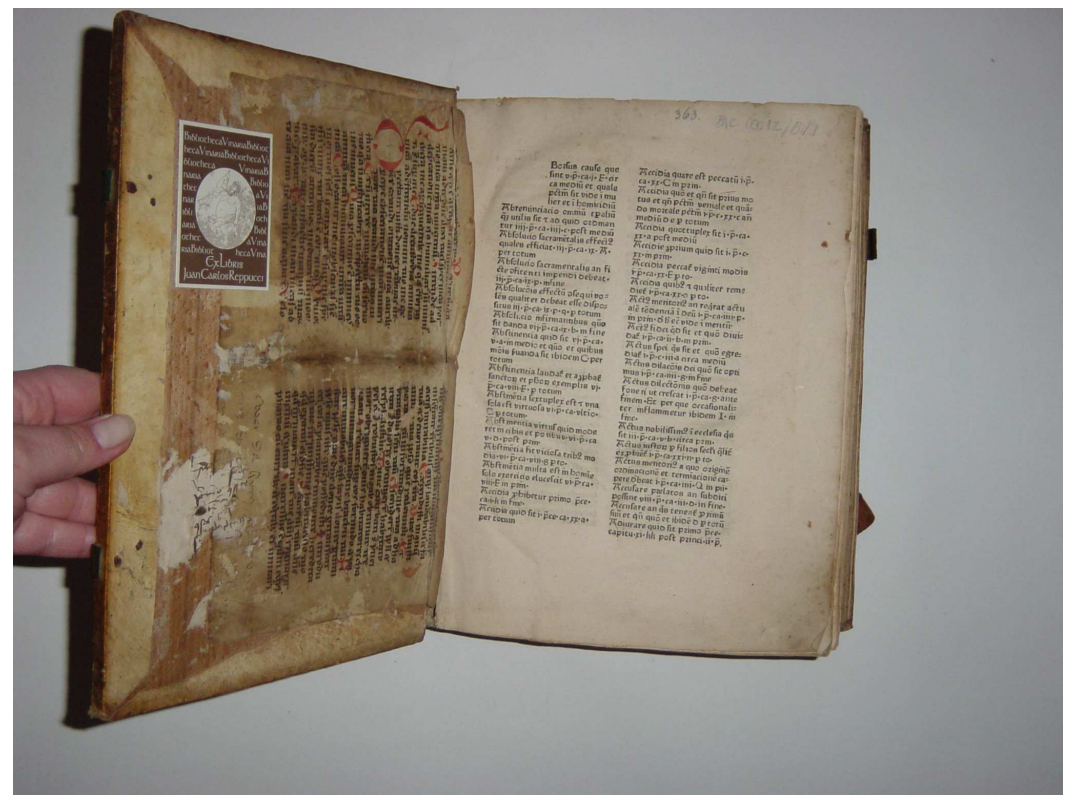

Fig. 8 - Detalhe do livro aberto, onde pode-se observar a guarda em pergaminho manuscrito.

Pelas referências consultadas, a da data pode ser equacionada como não posterior a 1478 porque duas cópias, uma na Biblioteca de Stuttgart e outra na Biblioteca de Munique, têm 1478 como data de compra; já Polain data a obra de cerca de 1475.

Encadernação de época, com capas de madeira revestida com couro de porco ao alúmen, com fechos em metal parciais (devido à perda dos fechos o livro encontra-se levemente aberto), presença de três nervos duplos e cabeceado bordado saliente. Reforço de pergaminho manuscrito colado nas capas, como uma guarda; há indicio de uma guarda em papel, também manuscrita, sobreposta ao pergaminho, que se perdeu, restando apenas um fragmento (ilustração).

Johannes Nider, nasceu em Isny (Alemanha), tornou-se religioso, teólogo e prior dos dominicanos. Escreveu várias obras. Em Preceptorium divinae legis, sive expositio decalogi apresenta na segunda parte cuidadosa interpretação do Decálogo para os confessores e pregadores. O interesse vinário está no tratamento do sexto mandamento, pois ao explaná-lo, fala, entre outras coisas, que os sarracenos jamais tomavam vinho; que Carlos Magno tomava vinho apenas três vezes por mês; e que um dos reis da França possuía um copo, em cujo interior fizera gravar um sinal: o vinho que nele bebia não podia ultrapassar essa marca. 


\section{0}

\section{9.}

\section{LIVIUS, Titus (ca. 59 a.C. - 17 d.C.)}

\section{Historia romana decades.}

[Treviso] : Michael Manzolus, 31 de outubro de 1480.

[372] f. ; $30 \mathrm{~cm}$ (in fol.).

Texto em latim. Edição de Johannes Andreas, Bispo de Aleria.

Assinatura: $a^{9} b-f^{8} g^{6} h-I^{8} s-X^{6} y-G^{8} H^{10} I-L^{8} M-N^{6} O^{8} P^{6} Q-R^{8} S^{6} T^{8} V-X^{6} Y^{7}$

51 linhas + tit. corr, caracteres romanos.

Impresso em preto com algumas anotações manuscritas, com letras de espera e espaços vazios para a pintura de capitulares que não foram executadas.

Encadernação moderna em pleno

Assunto: História

Interesse vinário: Embriaguez, história do vinho.

Referências: Arnoult 964; BMC VI 890; Goff L242; Hain 10134; Hubay(Würzburg) 1352; IBE 3526; IGI 5775; Mittler-Kind 418; Proctor 6478; Sallander 2299; Sheppard 5508; Zehnacker 1429.

Banco de dados: ISTC i100242000; GW M18473.

Exemplares conhecidos: 44 (5 imp., 2 frag.).

Outros incunábulos na BVR: $\mathrm{n}^{\circ} 19$

\section{1}

Folha Ir (ass: $a_{i i}$ ): [ ${ }^{6}$ ]AVSTO ac felici folo tuam Vrbē Pater beatiflime Paule.II.Venete // Pon. Max. Ac fortunatis originibus pofitā a primis illius fūdatoribus // etc.

Folha $3 r$ (aass: $a_{i i i i}$ ): Epitoma decadum quattuordecim. T. Liuii Patauini // Hiftorici in centum \& quadraginta libros diftinctum. // etc.

Folha 22r: LIBER PRIMVS. // T. Liuii Patauini Hiftoriciab Vrbe // condita decadis primæ. Liber Primus. // [ ${ }^{6}$ ]Acturus ne fim opere pretium: fi a primordio urbis res populi ro. // etc. 
Folha 371r: (27 linhas) // T. Liuii Patauini Hiftorici Illuftris Decadis quartæ libri finiūt: quos Michael Man // zolinus Parmenfis: ductu: imprenfa: folertiq3 diligentia: uiuentibus. pofterif q3 impri // micurauit Anno falutis. M.CCCC.LXXX. Pridie Calendas Nouembres. Folha 371v: Branca

Folha 372r: Bartholomæus Parthenius Gir. Bænacenfis Francifco // Throno Ludouici .F.Patricio Veneto præclaro .S. // $\left(\mathrm{h}^{4}\right)$ Iftoriam effe rem geftam \& ab ætatis noftræ memoria remotā inutroq3 // etc.

Folha 372v: (37 linhas) // EI***EM BARTHOLOMAEI PARTHENII AD LECTOREM. // (10 linhas) // Quare age prifcarum rerum ftudiofa iuuentus // Hunc 1*ge: qui uarias contulit Hiftorias.

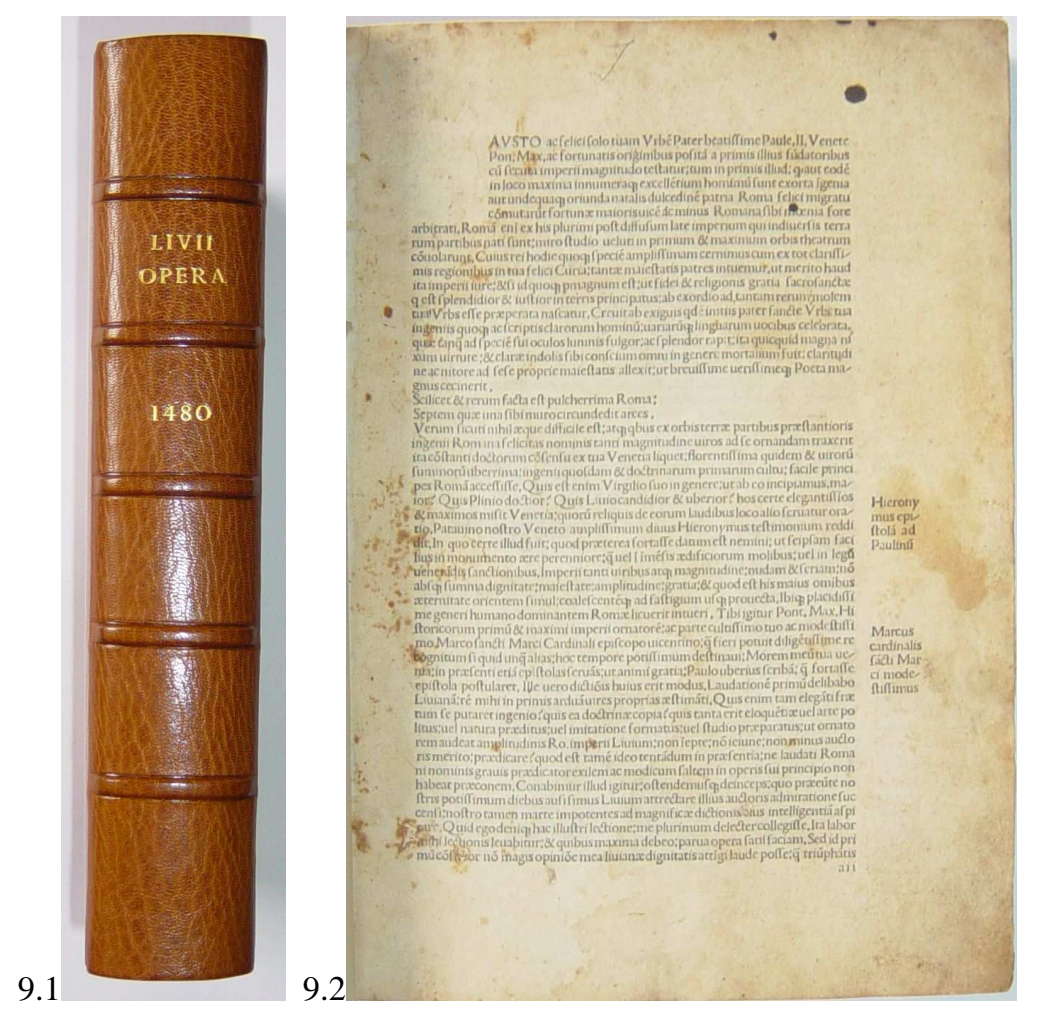

Fig. 9.1 e 9.2 - Detalhe da encadenação (lombada) e página de abertura da obra (f. 1r)

Encadernação inglesa moderna em couro e assinada: "BOUND BY SANGORSKI \& SUTCLIFFE. LONDON. ENGLAND". ${ }^{30}$ Cortes jaspeados em vermelho, presença de manchas de umidade em algumas folhas, primeiras e últimas folhas em pior estado, mas em geral exemplar limpo e com boa margem. De acordo com GW são 374f., sendo a primeira e a última em branco.

\footnotetext{
${ }^{30}$ Ateliê de encadernação fundado em 1901 e ainda em atividade em Londres.
} 
Titus Livius nasceu e morreu onde hoje é Pádua; de origem humilde, sua educação se fez pelo estudo da fiilosofia tornando-se competente escritor. Quando chega a Roma torna-se reponsável pela educação do futuro imperador Cláudio, mas sempre se mantém longe da política. Seus primeiros escritos foram obras filosóficas que se perderam. Sua obra História Romana, que conta a história da cidade de Roma desde sua fundação até o ano 9 a.C., originalmente era composta de 142 livros ou capitulos, divididos em gupos de dez livros, daí Décadas. Chegaram até nossos dias apenas 35 livros, que são: I ao X e XXI ao XLV (com algumas lacunas). Sobre o vinho há passagens que o citam brevemente, como: o interesse dos gauleses pelo vinho italiano, o seu uso em festas e a embriaguez que provoca. 


\section{0.}

\section{PLATINA, Bartholomaeus (1421- 1481)}

\section{De honesta voluptate et valetudine.}

Cividale : Gerardus [de Lisa] de Flandria, 24 de outubro de 1480.

[93]f. ; $21 \mathrm{~cm}\left(\right.$ in $\left.4^{\circ}\right)$.

Texto em latim. Obra dedicada ao Cardeal Roverella.

Assinatura: $\left[\mathrm{a}-1^{8} \mathrm{~m}^{5}\right]$

32 linhas, caracteres góticos; registro; letra-guia.

Filigrana: pato (festo)

Encadernação moderna em pergaminho com caixa de conservação. Presença de anotações manuscritas marginais

Assunto: Gastronomia

Interesse vinário: História do vinho.

Referências: BInG p.1320; BMC VII 1094; Brunet IV 690; BSB-Ink P-561; CIBN P-439; CIH, 2768; Delisle 1482; Fac: Udine, 1994 (edd. P. Micoli and M. Micheluti); Goff P-763; Graesse V p. 312; Günt(L) 562; Hain *13052; Hanssler p.581; Hubay(Augsburg) 1684; IBE 4653; IDL 3710; IGI 7850; Klebs 783.3; Mendes 1047; Oates 2707; Pell Ms 9507 (9329); Pol., 3183; Polain(B) 3183; Proctor 7266; Sajó-Soltész 2768; Sheppard 6029; Simon BBI p.91; Torchet 766; Vicaire 689; Voull(B) 2853; Walsh 3553; Zehnacker 1892.

Banco de dados: CCPB 000111888-9; GW M33895; ISTC ip00763000.

Exemplares conhecidos: 84 (4 imp., 1 vend.).

Outros incunábulos na BVR: $n^{\circ} 2$ e $n^{\circ} 60$

00098

Folha 1r: Platyne De Honefta Uoluptate: т Ualitudīe. ed // Ampliflimū ac Doctiflimum. D.B. Rouerellam // .S. Clemētis Prelbiterū Cardinalem. // .Liber primus. (e ${ }^{4}$ ) Rrabūt 7 quidē vehemēter Ampliflime // etc.

Folha 80v, linha 9: finif. // Uiri doctiflimi Platyne opufculum de obfo- // niis: ac de honefta voluptate $T$ valitudi- // ne impreffus in Ciuitate Auftrie: // impenfis $T$ expenfis 
Gerandi // de Flandria. Uenetiarus // Duce Inclito Io- // hanne Mocēico. // Nono kalendas Novembris. // $\mathrm{M}^{\mathrm{o}} . \mathrm{cccc}^{\mathrm{o}} . \mathrm{xxx}^{\mathrm{o}}$. // Laus Omnipotenti Deo. //

Folha 90r: Platyne de honefta // voluptate: 7 valitudine // libri primi capitula. // deligendus locus ad ha- // bitandum. .2. // etc.

Tabula segue até folha $93 r$

Folha 93v: registro
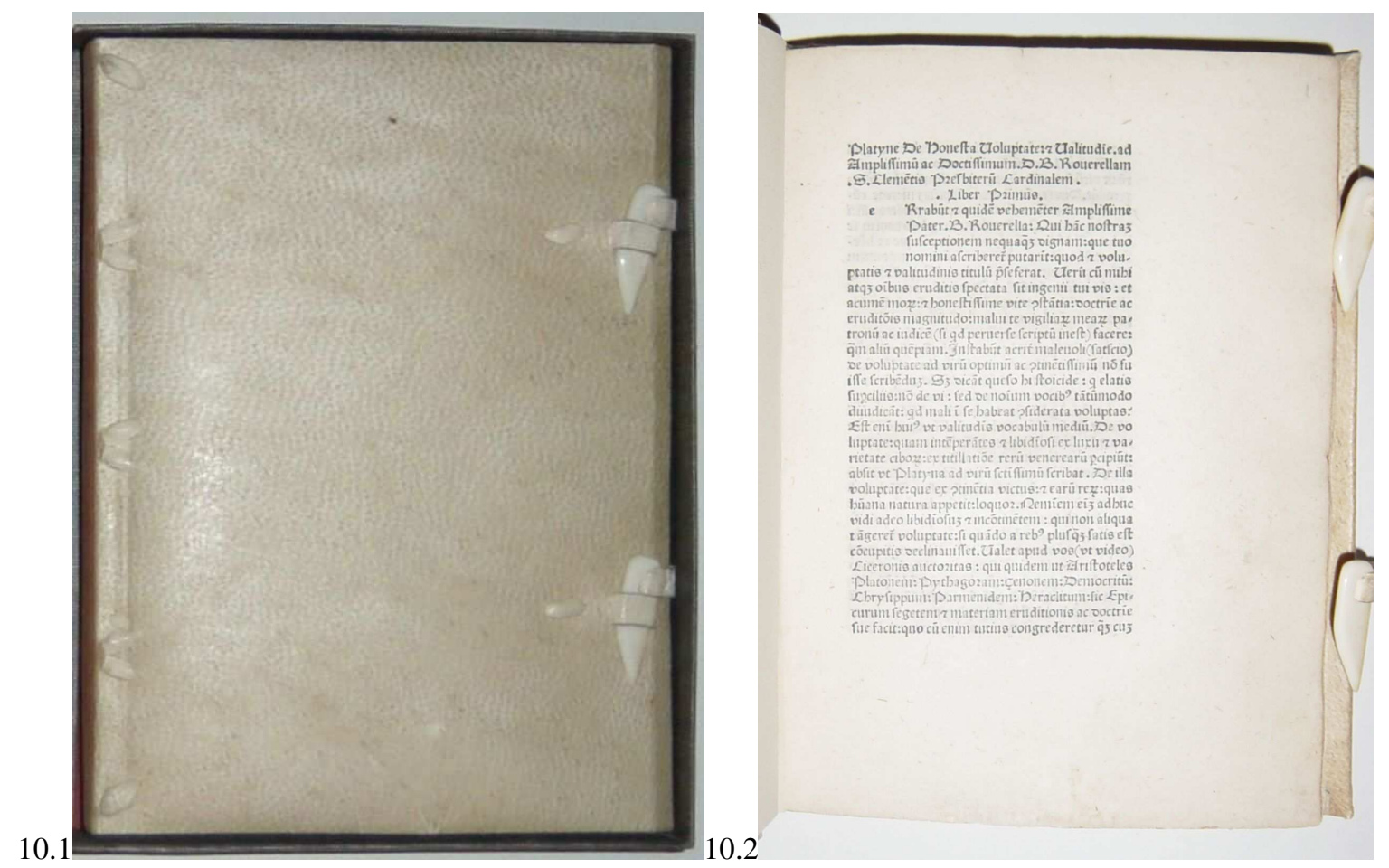

Fig. 10.1 e 10.2 - Detalhe da encadernação e página de abertura da obra (f. 1r).

Encadernação moderna em pergaminho flexível, com fechos em couro e marfim, em caixa de conservação revestida de tecido (ilustração). De acordo com referências, falta a última folha branca. Trata-se de exemplar com margens amplas, poucas anotações e bom estado de conservação.

De acordo com Proctor esta é a primeira obra impressa em Cividale. Gerardus de Lisa iniciou-se como impressor em Treviso em 1471, depois foi para Veneza em 1477, chegando a Cividale em 1480 onde atuou até 1484, indo depois para Udine e retornando a Treviso em 1492. Depois dele só haverá imprensa novamente em Cividale no século $\mathrm{XVII}^{31}$.

\footnotetext{
${ }^{31}$ Em 1768 com o impressor Valerio de Valeri.
} 


\section{1}

11.

BARTHOLOMAEUS ANGLICUS (ca. 1203-1272)

De proprietatibus rerum.

Colonia : Johann Koelhoff, o velho, 1481.

[446]f. ; 24,5 cm (in fol).

Texto em latim.

39-40 linhas; caracteres góticos [tipos: 7:95G, 9:150G]; reclamos; espaço para iniciais.

Filigrana: letra "P"

Exemplar rubricado e com iniciais pintadas em vermelho e faltando as 10 folhas preliminares e as duas brancas. Encadernação antiga em pleno couro com capas de madeira.

Assunto: Enciclopédia

Interesse vinário: Vinicultura, viticultura.

Referências: Arnoult 205; BMC I 223; CIBN B-97; CIH 501, Goff B-133; Graesse III p.91; Günt(L) 638; Hain 2501, IBE 752; IBP 798; IDL 672; Klebs 149.4; Ohly-Sack 389; Pell. 1868; Pol. 499 (+Supl.); Polain(B) 499; Proctor 1048; Sack(Freiburg) 460; SajóSoltész 501; Sheppard 800; Simon BBI 18; Voull(B) 771; Voull(K) 219.

Banco de dados: CCPB 000107987-5; GW 3405; ISTC ib00133000.

Exemplares conhecidos: 35 (6 imp.).

Outros incunábulos na BVR: $n^{\circ} 13$ e $n^{\circ} 71$

04376

Folha 1r: Incipit phemiū de proprietatib ${ }^{9}$ re $\pi$ fratris // Bartholomei anglici de ordine frat $\pi$ $\operatorname{mino} \pi / /\left(\mathrm{C}^{9}\right)$ um proprietates re $\pi$ fequanc // fubfitantias...

Folha 446v: (22 linhas) // Explict tractatus de proprietatibus re $\pi$ edit ${ }^{9} / /$ a frē bartolomeo $\bar{a}$ glico ordis frat $\pi$ mino $\pi$. // Impreffus per me Iohānem koelhoff de // lubeck Colonie ciuem. Anno natiuitatis // domini. Mcccclxxxi. 


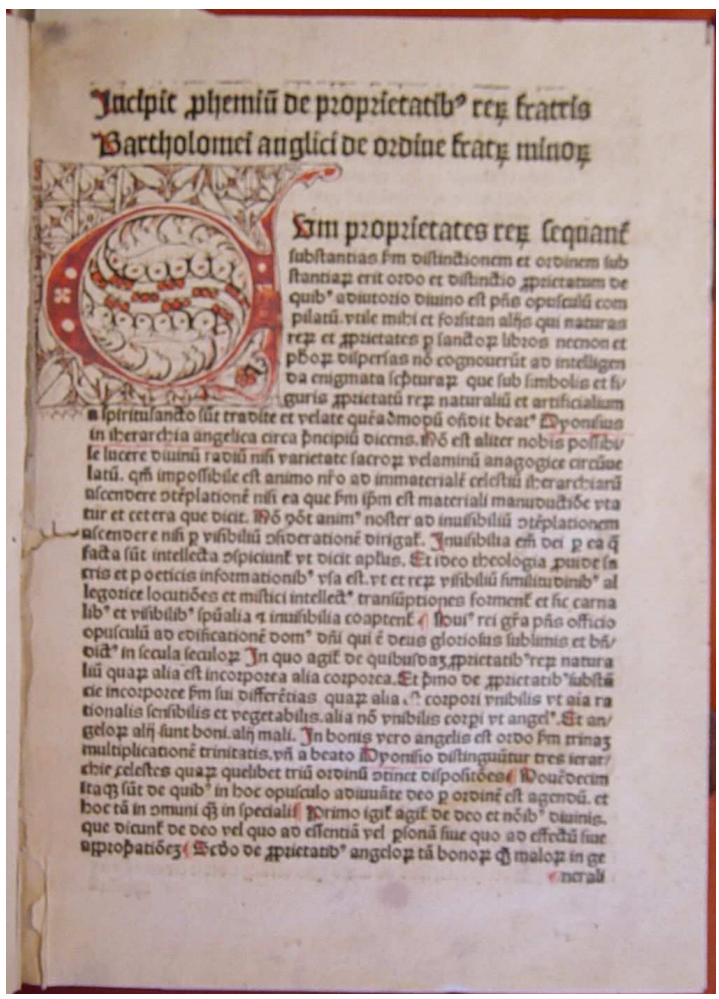

Fig. 11 - Página de abertura da obra (f. 1r).

Encadernação antiga, provavelmente do século XVI, com capas de madeira recobertas com couro, lombada com três nervos salientes e etiqueta manuscrita em pergaminho, pastas decoradas com diversos ferros a seco, presença de fechos metálicos.

Este exemplar sofreu bastante com o tempo: umidade, fungos, insetos $\mathrm{e}$ intervenções. Presença de folhas com manchas de umidade e fragilizadas pelo ataque de fungo; diversas folhas restauradas; os cortes da obra foram lixados ou guilhotinados recentemente (provavelmente na última intervenção, por estar bem limpo); há indicios de uma páginação manuscrita antiga que foi refilada e a margem é bem pequena (principalmente na cabeça e frente); encadernação restaurada com lombada nova em couro e fechos refeitos; além da ausência das folhas iniciais (de acordo com referências, este exemplar está iniciando na folha 12, mas o texto está completo). E por estes aspectos, fortalecidos pelos cortes do livro e a seixa da encadernação ser proporcional ao miolo, questionamos se a encadernação é original desta obra ou um reaproveiramento, prática comum em todas as épocas (o livro poderia ter sido refilado em algum momento para se adaptar às capas que pertenceram a outro livro).

Desconhecem-se as data de nascimento e morte do inglês Bartolomeaus Anglicus que em 1224 ou 1225 fez-se frade franciscano, fato que o levou a ser confundido com outro 
franciscano, Bartlomaeus (de) Glanvilla ${ }^{32}$, ao qual se atribuía esta obra (De proprietatibus rerum). Pesquisas recentes deixaram fora de questão que a obra é mesmo de Bartolomeaus Anglicus e que eles não foram a mesma pessoa. De proprietatibus rerum é uma verdadeira enciclopédia da Idade Média, que foi muito popular, tendo vinte e quatro edições impressas no século XV (em latim e traduções); e ainda hoje é fonte valiosa para os estudiosos do período. De ampla abrangência, a obra trata de diversos temas desde Deus, anjos e demônios, astrologia até geografia, metais e minerais, animais e vegetais, alimentos e bebidas, entre outros. Quatorze capítulos são dedicados ao tema vinário, como: Da vinha; Da vinha selvagem; Do vinho; Do vinho tinto; Do vinho novo; Do vinho artificial, etc.

32 O próprio Simon mistura os dois personagens referindo-se ao autor da obra como Bartholomaeus de Glanvilla, Anglicus. 


\section{2.}

\section{PLINIUS SECUNDUS, Caius (23 d.C. - 79 d.C.)}

\section{Historia naturalis = Historia Naturale}

Veneza : Filippo di Pietro, 1481.

[291]f. ; $31 \mathrm{~cm}$ (in fol.)

Texto em italiano. Tradução do latim de Christophorus Landinus.

Assinatura: $a-h^{8} i-o^{6} p^{8} q^{10} r-K^{8}[1]$

2 colunas; 59 linhas; caracteres góticos; registro; espaço para iniciais; letras-guia.

Filigranas: âncora (guardas) e cabeça de boi.

Procedência: "N. Julius C Cesar de Maueris" (assinatura f. 14)

Exemplar com anotações manuscritas. Encadernação flexível em pergaminho em caixa de conservação.

Assuntos: Enciclopédia, história.

Interesse vinário: Vinicultura, viticultura, história do vinho.

Referências: BInG p.1334; BMC V 223; BSB-Ink P-612; CIBN P-470; Goff P802; Graesse V, p.344; HC 13106; Hensseler p.584; IBE 4686; IGI 7894; Klebs 787.2; Oberlé(Fastes) p.40; Pell Ms 9546 (9369); Voull(B) 3732; Zehnacker 1907bis.

Banco de dados: CCPB 000111921-4; GW M34343; ISTC ip00802000.

Exemplares conhecidos: 54 (10 imp., 2 frag.).

Outros incunábulos na BVR: $n^{\circ} 3$ e nº 66

Folha $\operatorname{lr}$ (ass. $a_{2}$ ), $1^{a}$ col.: Libro primo della naturale hiftoria de C. Pli- // nio fecondo tradocta $\overline{1}$ lingua Fiorentina per Chri // ftophoro landino Fiorentino al Sereniflimo Ferdi // nando Re di Napoli. // etc.

Folha 12v: branca

Folha 13: branca

Folha 14 (ass. a): Libro fecondo della hiftoria naturale de . C: // Plinio Secondo Tradocta de lingua latina in fio // rentina per Chriftpphoro landino fiorentino al // Seremiflimo Ferdinando re di Napoli. // Sel Mondo ha termini 7 fe e uno. Caplo .i. // $\left(\mathrm{e}^{8}\right) 1$ mondo 7 quefto elqua // etc. 
Folha 291v, 2 coluna: (21 linhas) // Opus Magiftri Philippi Ueneti Impreffum an // no Salutis .M. cccclxxxi. Uenetiis.

Folha 292r: registro

Folha 292v: branca
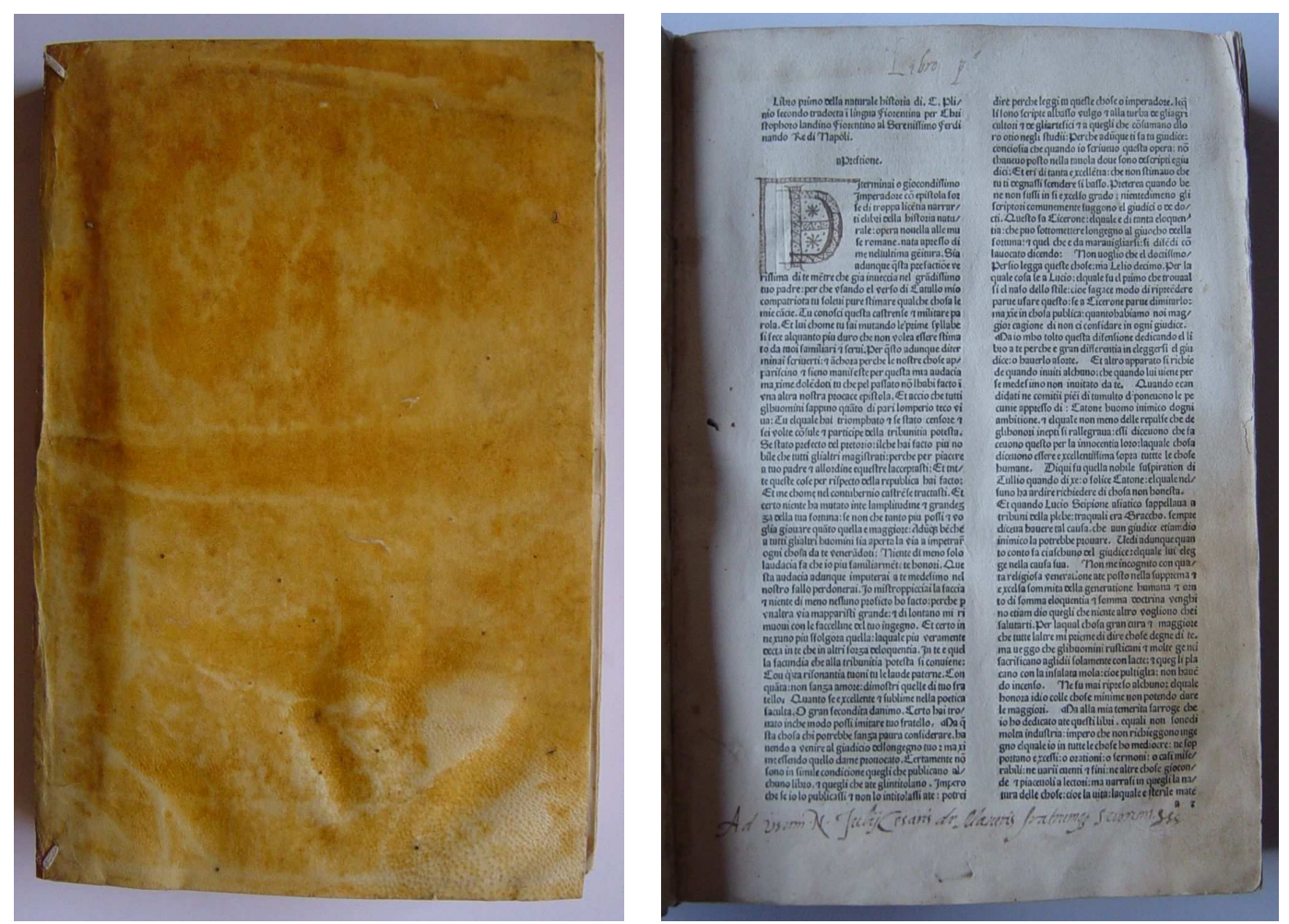

Fig. 12.1 e 12.2 - Detalhe da encadernação em pergaminho e da folha de abertura da obra (f. 1r).

De acordo com as referências consultadas a primeira e a última folha da obra são brancas e estão ausentes neste exemplar que se inicia na folha com assinatura $\mathrm{a}_{2}$ e termina na $b b_{7}$.

A encadernação flexível em pergaminho, provavelmente do século XVII, foi restaurada e está fixada ao livro apenas pelos cordões do cabeceado (bordado em rosa e bege), mas indícios no pergaminho mostram que originalmente a capa também era fixa pelos nervos da costura e possuía fechos de couro (botões ou tiras). As inscrições manuscritas da lombada estão ilegíveis, com exceção do ano "1481". Exemplar com algumas anotações manuscritas nas primeiras e últimas folhas, incluido iniciais manuscritas amadoras (ilustração).

Esta é a segunda edição em italiano; a primeira, raríssima, foi impressa em Veneza por Nicolaus Jenson em 1476. 


\section{2}

\section{3.}

BARTHOLOMAEUS ANGLICUS (ca. 1203-1272)

\section{De proprietatibus rerum.}

[Lyon] : Petrus Ungarus (Pierre Hongre), 21 de novembro de 1482.

[256]f. ; $29 \mathrm{~cm}$ (in fol.)

Texto em latim.

Assinatura: $a-d^{10} e^{8} f-h^{10} i-k^{12} l-t^{10} u-x^{12} A-E^{10} F^{12}$

2 colunas; 54 linhas; caracteres góticos; espaço para iniciais.

Exemplar rubricado com iniciais e parágrafos em vermelho. Encadernação moderna, em marroquino verde, com cortes dourados e assinada: "CAPE".

Assunto: Enciclopédia

Interesse vinário: Vinicultura, viticultura.

Referências: Arnoult 206; BMC VIII 268; Brunet II, 1620; BSB-Ink B-93; CIBN B98; CIH 502; GfT 2118; Girard 64; Goff B-134; Graesse III, p.91; Günt(L) 1672; Hanssler, p.67; HC 2502; IBE 753; IBP 799; IGI 1253; Klebs 149.5; Madsen 546; Oates 3197; Parguez 136; Péligry 139; Pell 1869; Pol. 500; Polain(B) 500; Proctor 8573; Sack(Freiburg) 461; Sajó-Soltész 502; Sallander 1600; Simon BBI, p.22; Zehnacker 358bis.

Banco de dados: CCPB 000107988-3; GW 3406; ISTC ib00134000.

Exemplares conhecidos: 53 (8 imp.).

Outros incunábulos na BVR: n $^{\circ} 11$ e 71

02536

Folha 1: branca

Folha 2r: Prohemium // Incipit prohemiū de proprietatibus re // rum fratris Bartholomei anglici ð ordine fra // trum minorum. // etc.

Folha 255r: (18 linhas) // Explicit tractatus de pprietatibus rerum // editus a fratre bartholomeo anglico ordinis // fratrum minorum. Impreffum per Petrum vnga $\pi$. Sub anno 
domini. Millefimoqua // dringentefimooctuagefimofecundo. Die vero // nouembris.xxi. // Finis // Laus deo.

Folha 255v: branca

Folha 256: branca

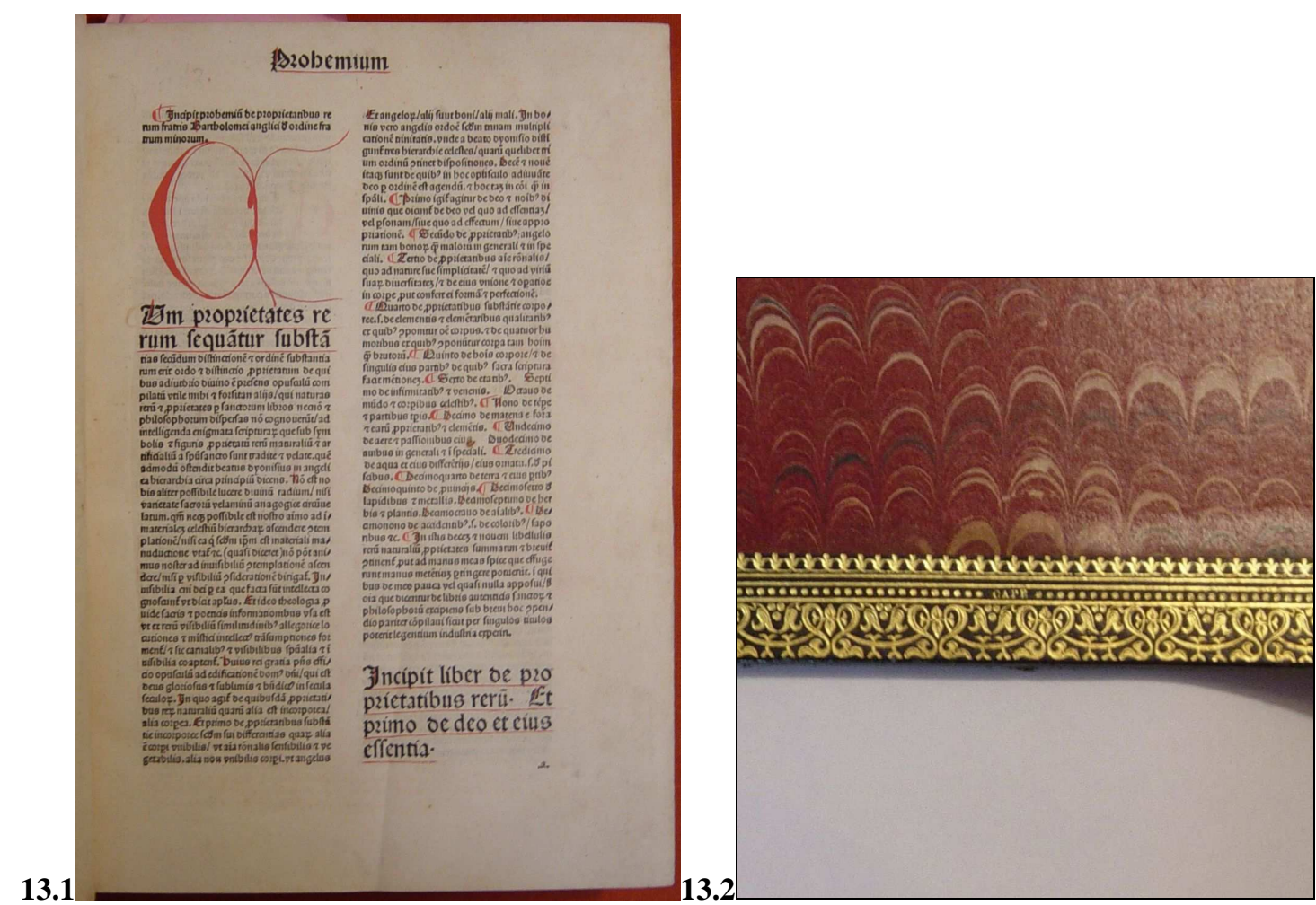

Fig. 13.1 e 13.2 - Página de abertura do texto e detalhe da assinatura da encadernação.

A encadernação da obra é do século XIX, em marroquino verde, lombada com cinco nervuras salientes e gravação em dourado com nome da obra e data, cortes dourados e com assinatura "CAPÉ". Exemplar com papel muito limpo e com algumas iniciais e marcações de parágrafos em vermelho borradas (provavelmente o livro foi restaurado por processos aquosos sem a fixação das tintas).

Charles Capé (1806-1867), de origem modesta e pouca cultura, iniciou-se como zelador do Louvre, foi aprendiz de papéis decorados e chegando depois a encadernador. Em 1848 cria seu próprio ateliê e torna-se um dos primeiros clientes de Marius Michel $^{33}$ a quem encaminhava suas encadernações para serem decoradas. Capé foi encadernador da Emperatriz Eugênia, dedicou-se também ao comercio de livros e constituiu uma biblioteca magnífica. (DEVAUCHELLE, 1995, p. 236). Esta encadernação de Capé não é das mais

\footnotetext{
${ }^{33}$ Marius Michel foi um dos maiores mestres da douração e decoração do século XIX.
} 
luxuosas, nem possui decoração de mosaicos ou douração; trata-se de trabalho bem executado e sóbrio; provavelmente nesta ocasião a obra foi restaurada e o papel foi lavado (o que pode ser comprovado pelas iniciais vermelhas que estão borradaa e pela brancura excessiva do papel). Aparentemente foi a estética da época que o levou a este tratamento extremo; hoje, com enfoque voltado para a conservação, provavelmente seria evitado, pois a obra não apresenta problemas que justificassem este tipo de intervenção, apenas alguns buracos de insetos junto ao festo ${ }^{34}$.

Esta é a primeira obra datada impressa por Petru Ungarus, ou Pierre Hongre; a obra de Augustinus de Ancona, Summa de potestate ecclesiastica ${ }^{35}$ é possivelmente anterior mas não tem indicação de imprenta.

\footnotetext{
${ }^{34}$ De forma resumida pode-se dizer que o tratamento aquoso no restauro de livros é aconselhável para obras com sérios problemas de unidade, ataque biológico (fungos e insetos), remoção de intervenções anteriores que prejudicam a obra e necessidade de reintegração do suporte. A reintegração mecánica ou manual do suporte é a sua "reconstrução" através de enxertos e reparos com fibras de celulose ou papel japonês, nas áreas com perdas, fragilizadas ou com rasgos. Somente no caso de obra de arte sobre papel é que se justifica o tratamento visando a estética, pois esta é sua função, enquanto que a função de um livro é a sua leitura; portanto, se existem manchas, que não prejudicam a leitura da obra, não se justifica o tratamento apenas para clarear o papel.

${ }^{35}$ Augustinus de Ancona. Summa de potestate ecclesiastica. [Lyon :Petrus Ungarus, not after 1480] ou [não depois de 18 de junho de 1484]. ISTC: ia01366000.
} 


\section{4.}

SCRIPTORES REI RUSTICAE. Marcus Porcius CATO. Enarrationes. De re rustica. Acresc.: Marcus Terentius VARRO. De re rustica; Lucius Junius Moderatus COLUMELLA. De re rustica; Rutilius Taurus PALLADIUS. De re rustica.

Reggio Emilia : Bartholomeaus Bruschus, 5 de junho 1482.

[303]f. ; $31 \mathrm{~cm}$ (in fol.)

Texto em latim. Edição de Franciscus Colucia e Georgius Merula.

Assinatura: $\mathrm{A}^{10} \mathrm{a}^{8} \mathrm{~b}-\mathrm{c}^{10} \mathrm{~d}^{8} \mathrm{e}-\mathrm{g}{ }^{10} \mathrm{~h}^{8} \mathrm{i}^{6} \mathrm{k}-\mathrm{l}^{10} \mathrm{~m}-\mathrm{dd}^{8}$ ee- $\mathrm{hh}{ }^{10}[1]$

40 linhas; caracteres romanos; registro; letras-guia.

Filigranas: pomba (?)

Procedência: André L. Simon e Charles Butler (ex-libris).

Encadernação em pleno couro, com decoração a ouro nas capas e lombada.

Assunto: Agricultura

Interesse vinário: viticultura, vinicultura

Referências: Aquilon 607; BInG, p.1551; BMC VII 1086; Borm 2424; Brunet V, 245; BSB-Ink S-233; CIBN S-175; CIH 3056; Goff S-347; Graesse VI, p.331; Hain 14565*; Henssler, p. 679-680; IBE 5173; IBP 4959; IDL 4071; IGI 8854; Jammes S8; Klebs 902.2; Madsen 3651; Mittler-Kind 548; Pell Ms 10382 a-d; Proctor 7251; Sack (Freiburg) 3195; Sajó-Soltész 3056; Sheppard 6009; Simon BBI 42 (este exemplar); Voull(B) 3292; Walsh 3537; Zehnacker 2086.

Banco de dados: CCPB 000112408-0; GW M41061; ISTC is00347000.

Exemplares conhecidos: 84 (20 imp., 1 frag.).

Outros incunábulos na BVR: ${ }^{\circ} 69$

02891

Folha 1r: branca

Folha 2v: ( g ) Eorgius Alexandrinus Petro Priolo. M. Filio S. Prifcas dictiones // etc.

Folha $2 r$ (ass. $A_{i i}$ ): ENARRATIONES BREVISSIMAE PRI- // ACARVM VOCVM MARCI CATONIS.

Folha 15: branca

Folha 16r (ass. $b_{2}$ ): EPISTOLA // ( G )Eorgius Alexandrinus Bernardo Iuftiniano equiti \& fenatori // facundiflimo falutem. etc. 
Folha 20r: MARCI CATONIS PRISCI DE RE RUSTICA LIBER.

Folha 4lr: MARCI PRISCI CATONIS QVI HOMINVM SVMMVS // IN OMNI VSV FVIT DE RE RVSTICA LIBER VNVS. // IS ENIM ABSOLVTVS NEC IMPERFECTVS PLINIO // AVCTORE COLLECTVS EST.

Folha 43 r (ass. e): MARCI TERENTII VARRONIS RERVM RVSTICA- // RVM AD FVNDANIAM VXOREM LIBER. I. PROLOGVS.

Folha 85v: MARCI TERENTII VARRONIS QuI REM RVSTICAM // EXPOLIVIT LIBRI TRES. QuOS DILIGENTER ATQuE // VENVSTE IMPRESSIT BARTHOLOMEVS BOTTONVS // AT BRVSCHVS REGENSIS..M.CCCC.LXXXII.

Folhas 86 e 87: brancas

Folha 92r: LVTIII IVNII MODERATI COLVMELLAE REI RVSTI- // CAE LIBER PRIMVS. PRAEFATIO.

Folha 239v: LVCII IVNII MODERATI COLVMELLAE RERVM RV- // STICARVM LIBRI OPERA ET IMPENSA BARTHOLO // MAEI BOTTONI AT BRVSCHI REGENSIS IMPRES- // SI REGII DVCE HERCVLE IMPERANTE. M.CCCC.LX- // XXII.

Folha 240r (ass. $b b_{v i}$ ): EPISTOLA. // ( g )Eorgius Alexandrinus Dominico Georgio infigno patrio. S. // etc.

Folha 242: branca

Folha 243r: PALLADII RVTILII TAVRI AE MILIANI VIRI ILLVSTRIS // DE RE RVSTICA LIBER PRIMVS. TITVLI LIBRI PRIMI.

Folha 302r: PALLADII RVTILII TAVRI AEMILIANI VIRI ILLVSTRIS // DE RE RVSTICA LIBRI IMPRESSI REGII OPERA ET // IMPENSIS BARTHOLOMEI BRVSCHI AT BOTONI REGI- // ENSIS M CCCCLXXXII NONIS IVNII. Deinde: M. B. Bartholomeo Bottono at Bufco S. P. D.

Folha 302v: Prifcorum quicunque Itudet monumenta doceri // Terrarum \& cultus: arma deofque fimul. // Hos legat antiquos: Varronem tumque Catonis // Scripta: Columellam: Palladiumque legat. // Rura canunt: rurifque deos: bis uita magiftris // Defueuit querna peliere glande famem. // Impreflit regii: nuper uolumina quorum // Optime bottonus nomine Bartholomeus.

Folha 302r: Registro 

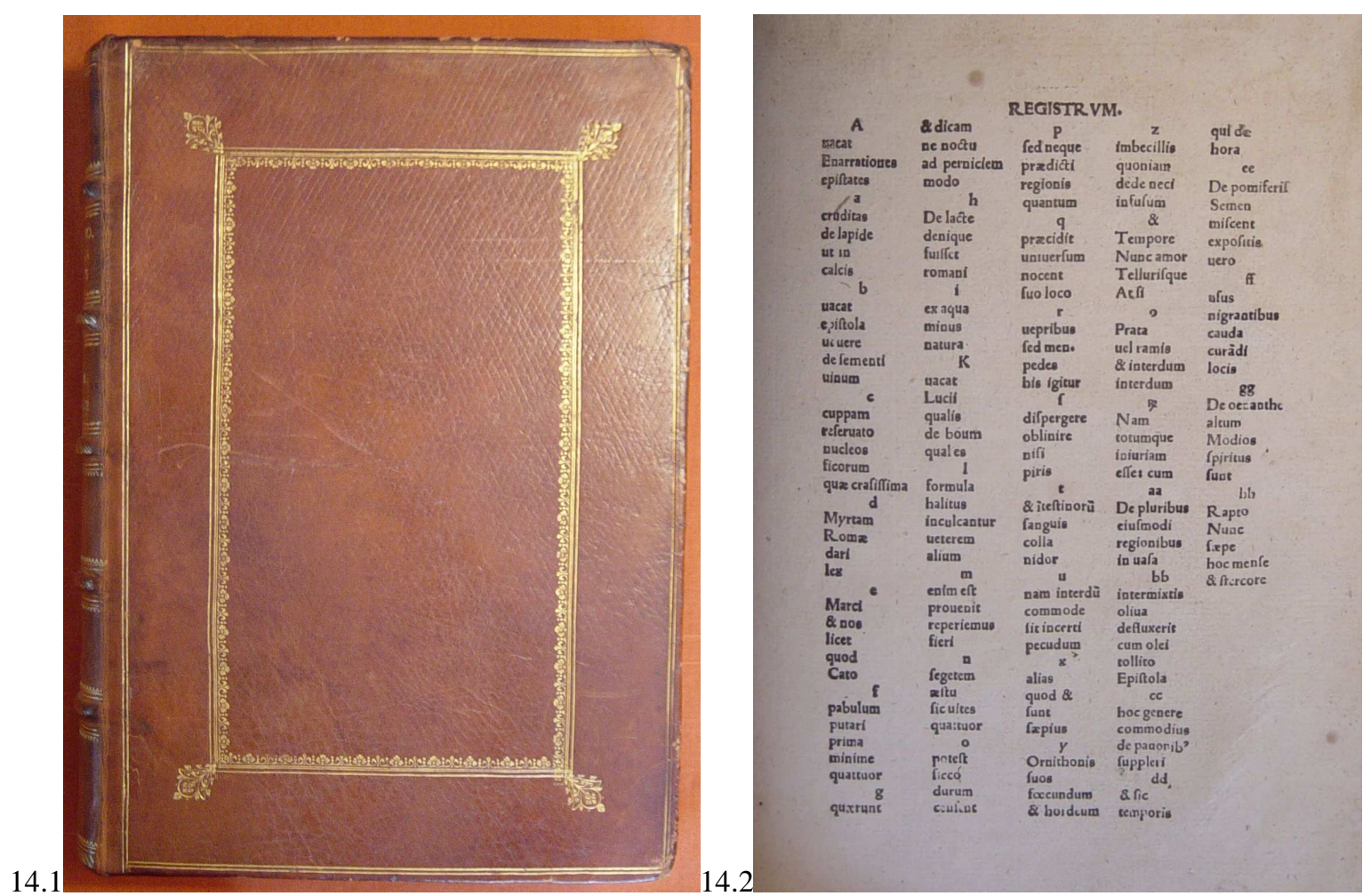

Fig. 14.1 e 14.2 - Detalhe da encadernação e do registro (f. 302r)

Curiosamente a obra termina com o registro (em folha acrescentada ao último caderno), que não consta da descrição de Hain; e Simon, que possuiu exatamente este exemplar e também cita Hain como referência, não reparou nesta diferença entre as discrições. Não tivemos acesso a outras referências com descrições detalhadas para confirmar se se trata de uma variação ou não (Brunet e Graesse citam edições de $302 \mathrm{f}$ possivelmente sem o registro, e em GW esta descrição está incompleta); optamos então pela reprodução do registro (figura ).

Encadernação do século XVIII, em pleno couro castanho claro, lombada com cinco nervuras decoradas com filetes, capa com enquadramento com fios e florões, corte superior pintado e guardas marmorizadas. Exemplar com boas margens, limpo, com poucas anotações, mas é possível que tenha passado por tratamento de restauro (há folhas com anotações apagadas).

Este volume agrupa trabalhos sobre agricultura de quatro escritores romanos de diferentes épocas, a saber:

Marcus Porcius CATO (234-149 a.C.) foi erudito, estadista e general romano, entre outras coisas; ficou na história pela sua profunda integridade moral. Escreveu a primeira história de Roma. Considerado o primeiro a escrever de forma sistemática sobre o vinho, 
figura aqui com a obra Enarrationes. De re rustica, na qual refere oito espécies de videiras e dedica mais de dez capítulos ao tema vinário.

Marcus Terentius VARRO (116-27 a.C.), um dos mais cultos e prolíferos escritores romanos, pouco restou de sua obra, sendo uma delas De re rustica, na qual dedica apenas dois pequenos capítulos à videira, acrescentando duas espécies às enumeradas por Cato.

Lucius Iunius Moderatus COLUMELLA (2 a.C. - 65 d.C.) romano nascido na Espanha (Cádiz). Dele diz Simon: "Tanto pela clareza do estilo quanto pela precisão de suas observações, merece sem contestação o primeiro lugar entre os autores que trataram de assuntos agrícolas e que se ocuparam da vinha e do vinho. Os Livros III e IV [da obra De re rústica] são inteiramente consagrados à cultura da videira; à escolha das espécies de videiras, das quais descreve 58 tipos; à escolha do solo e exposição dos vinhedos; ao tempo e à maneira de executar os diversos trabalhos exigidos pelo vinhedo, desde a plantação das tenras mudas até a vindima [...] No Livro XII, consagra os capítulos XVIII-XLI ao vinho, vindima, vinificação, espécies de vinho, doenças dos vinhos e seus remédios, vinagre etc."

Rutilius Taurus PALLADIUS escritor romano do século IV; em sua obra, também de nome De re rústica, segundo Simon, "trata da vinha no capítulo XVIII do Livro I [...] seu tratado é quase inteiramente extraído de Columela." 


\section{3}

\section{5.}

GRITSCH, Johannes (ca. 1410)

\section{Quadresimale.}

Nurenberg : Anton Koberger, 7 de março de 1483.

[225]f. ; 32,5 cm (in fol.).

Texto em latim. De acordo GW e nota em ISTC $^{36}$ o autor é Conradus Gritsch.

Assinatura: $\left[\mathrm{a}-\mathrm{f}^{8} \mathrm{~g}^{6} \mathrm{~h}^{8} \mathrm{i}^{6} \mathrm{k}-\mathrm{m}^{8} \mathrm{n}^{6} \mathrm{o}^{8} \mathrm{pq}^{6} \mathrm{rs}^{8} \mathrm{tv}^{6} \mathrm{x}^{8} \mathrm{yz}^{6} \mathrm{AB}^{8} \mathrm{C}-\mathrm{H}^{6} \mathrm{I}^{8}\right]$

2 colunas, 53-54 linhas e tit. corr., caracteres góticos [tipos: 8:84G, 9:165G].

Filigranas: cabeça de boi, coroa

Impresso em preto com iniciais em vermelho e azul. Encadernação original da época em pleno couro.

Assunto: Religião

Interesse vinário: Embriaguez.

Referências: BMC II 425; Borm 1215; BSB-Ink G-400; Coll(U) 649; Goff G499; Hain 8069*; Hubay(Augsburg) 962; Hubay(Würzburg) 996; IBE 2734; IBP 2553; IGI 4491; Ohly-Sack 1318; Polain(B) 1751; Proctor 2031; Simon BBII, p.88; Voull(B) 1694; Wilhelmi 277, 650.

Banco de dados: GW 11548; ISTC ig00499000

Exemplares conhecidos: 40 (1 imp., 1 frag.).

Fac-símile eletrônico disponível em Verteilte digitale Inkunabelbibliothek: <http://inkunabeln.ub.uni-koeln.de/vdib-info/kleioc/ig00499000>

Outros incunábulos na BVR: $\mathrm{n}^{\circ} 45$

04529

Folha 1: branca

Folha 2r: $\left[\mathrm{O}^{3}\right]$ Peris egregii // antea negligēter effigiati miPt9 col- // lectoris.immo ordinis fue pfeflio- // etc. Tabela termina na f. $16 \mathrm{v}$

\footnotetext{
${ }^{36}$ Nota no banco de dados ISTC: "According to Verfasserlexikon 2, Bd 3 col 291ff, the author is Conradus Gritsch (Sack(Freiburg))".
} 
Folha 17r: Quadragefimale fratris iohis Gritfch or- // dinis fratrum minorum. doctoris eximij. per to // tum tpis anni fpaciū deferuiens cum thematū // euangeliorum 7 epiftolarum introductionib $\mathrm{T}$ // tabula poptima Incipit feliciter. // $\left[\mathrm{C}^{16}\right] / / \mathrm{Vm}$ ieiunatis. nolite // fieri ficut ypocrite tri // etc.

Folha $25 r$ (ass. d): erat mane in diluculo. in q venit ihus ad difci- // etc.

Folha 211r: Texto termina $2^{\mathrm{a}} \mathrm{col}$, linha 48 aduenerit mei clamoris.mea merces fis huius // laboris. ac virgo beatiflima affit femper preca- // ta vt cum francifco feraphico fempiterno fru- // ar premio. Amen.

Folha 211v, $1^{a}$ col: Regiftrum de euāgeliorum et eplarum the // matibus atq3 introductōibus. Tādñicaliuz q3 // etc.

Folha 226r, $2^{a}$ col.: ( 44 linhas) // Petite $\mathrm{T}$ accipietis Ioh. xvj. Nota totum .xix. // B.D. Et tantū de fanctis in cōmuni. // Quadragefimale venerabilis dictoris Iohā- // nis gritfch de ordīe mino $\pi$ impēfis Anthonij // koburger Nurenberge poptime eft cōflūmatū // Anno falutis .M.cccelxxxiij. nonas marcias.

Folha 226v: branca.

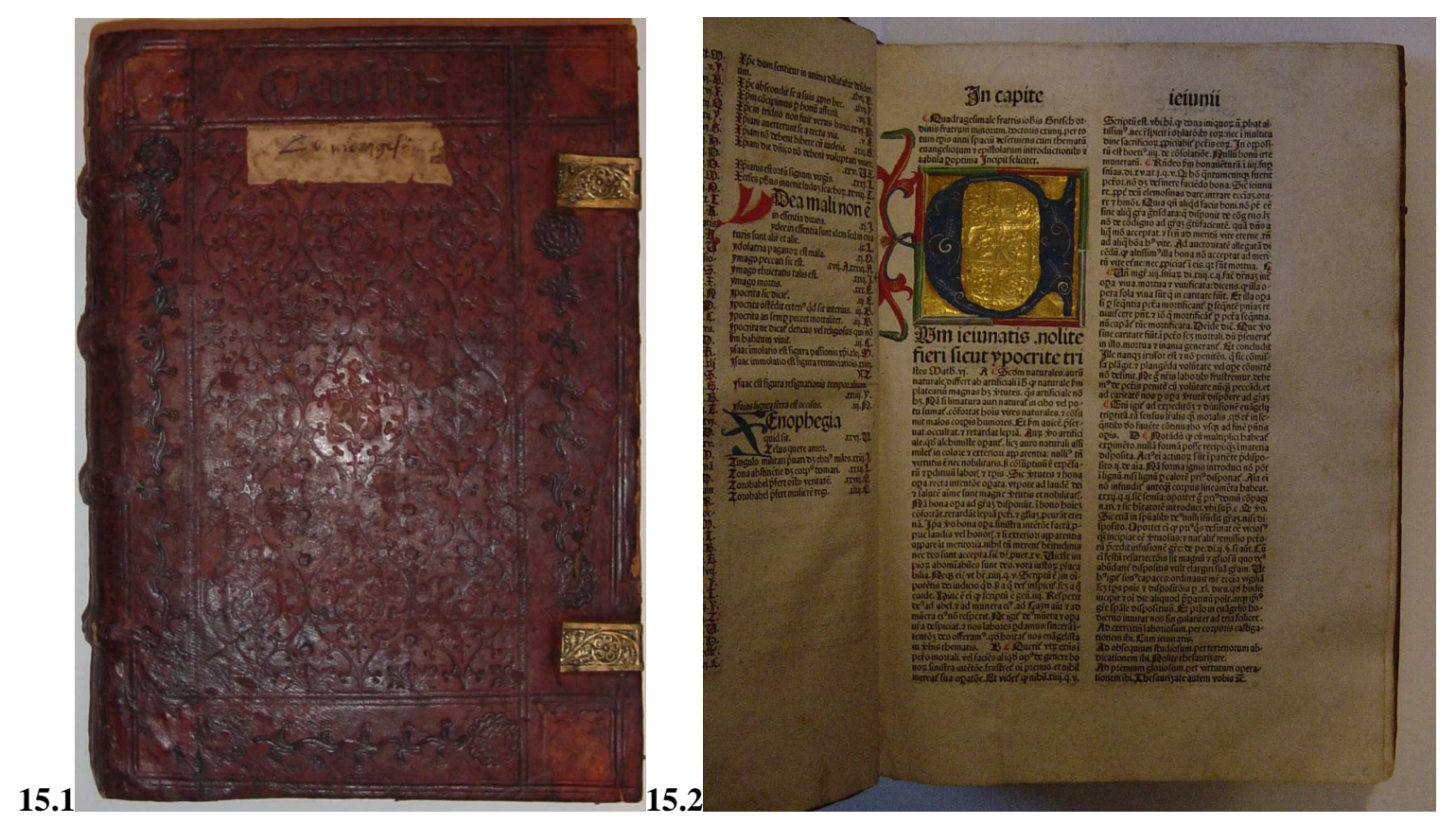

Fig. 15.1 e 15.2 - Detalhe da encadernação e da abertura do texto (f. 17r) 


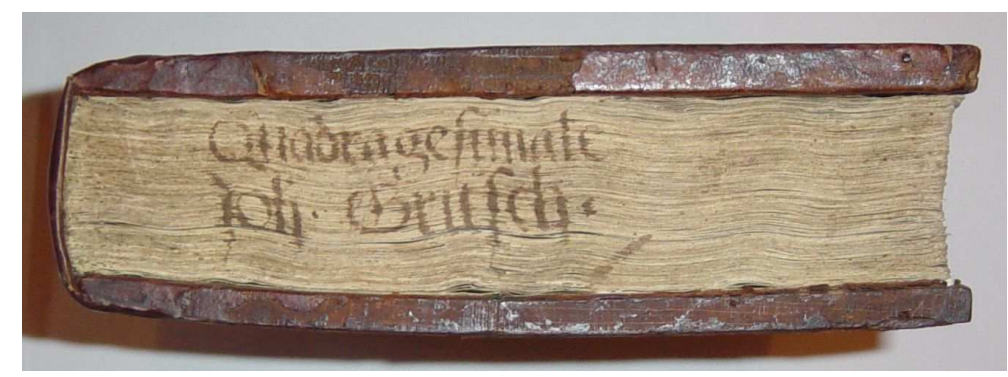

Fig. 15.3 - Detalhe do corte inferior de Quadragesimale.

Este exemplar possui belas iniciais em azul e vermelho, alternadas em toda a obra, mas somente na abertura do texto há uma capitular iluminada com fundo dourado.

A encadernação é original do século XV, em pleno couro sobre pastas de madeira, decorada com gravação a seco e nome do autor na pasta superior. Etiquetas de papel com inscrições manuscritas não identificadas se encontram na lombada e pasta superior. Apresenta pequenos restauros, perda dos cabeceados (elemento sempre presente em encadernações deste período) e fechos parcialmente conservados. No corte inferior encontra-se manuscrito o nome da obra e autor; este é um hábito que vem dos antigos livros manuscritos, que, por serem obras em sua maioria grandes e pesadas eram muitas vezes guardadas deitadas nas estantes: este era o melhor sistema para identificá-las.

Johannes Gritsch foi um clérigo secular e cônego da Basiléia, doutor das leis canônicas nas Universidades de Heidelberg e da Basiléia, tornando-se reitor da última em 1466. Mas acredita-se que Quadragesimale seja obra de seu irmão mais velho, Conradus Gritsch (ca.1409- ca.1475), frei franciscano, erudito, que estudou (ou foi leitor) em diversas cidades européias como: Estrasburgo, Paris, Viena, Zurique, Melhause, Heidelberg e Bern; manuscritos de seus estudos em filosofia e teologia se conservaram na Biblioteca de Fribourg (Suíça).

Passagens dos sermões I, VI e XXIII, fazem menção ao tema vinário: uso do vinho misturado com água, embriaguez como pecado mortal. 


\section{[ca.1477-1483]}

16.

MENSA PHILOSOPHICA.

Lovaina : Joannem de Westfalia, [ca.1477-1483]

[Johann de Paderborn, ca.1481].

[81] f. ; 21,0 cm (in $\left.4^{\circ}\right)$

Texto em latim, obra atribuida a diversos autores como Michael Scotus, Theobaldus Anguilbertus ou Konrad von Halberstadt, o jovem.

Assinatura: $\left[a^{5}\right] a-h^{8} i^{12}$

30 linhas; caracteres góticos; espaço para iniciais.

Filigrana: homem, coroa.

Procedência: John Rastell, Thomas Rowland, Jenkin Richard, William Foyle (anotações manuscritas)

Encadernação moderna em pleno couro, decoração com motivos vinícolas.

Assunto: Gastronomia

Interesse vinário: Gastronomia, história do vinho.

Referências: Arnoult 1093; Camp 1240; BMC IX 148; Goff M-492; Hain 11078; Henssler p.487; IDL 3196; ILC 1566; Klebs 576.3; Oates 3749, 3750, 3751; Polain(B) 2669, 2669A; Proctor 9276; Sheppard 7116, 7117; Vicaire 778.

Banco de dados: GW M22818; ISTC im00492000.

Exemplares conhecidos: 17 (1 imp., 2 destr.).

04310

Folha $1 r, 1^{a}$ col.: Incipit tabula in li // brum qui dicit Mensa // philofophica Et prīo // ponunt tituli pruni li // bri. // Prohemiū // De hora comeftionis T // etc.

Folha 5v: branca

Folha 6r: Prohemium in librum qui dicitur menfa philofo // phica Incipit. // [ ${ }^{5}$ ] Icut dicit Macrobius tercio libro fa // etc.

Folha 81v: (10 linhas) // Prefens liber (quē menfam philofophicā uocāt) // u nicuiP putilis cōpendiofe ptractās in primis qd // in cōuiuiis p cibis $\mathrm{T}$ potibus fumendū ê| deinde qui // fermones in illis fcðm exigentiā pfona $\pi$ habēdi funt // 7 que queftiones difcutiende que 
infuper facetie fiue // ioci interferendi feliciter explicit Imprefl ${ }^{9}$ louanii // per me ioannem de westfalia.
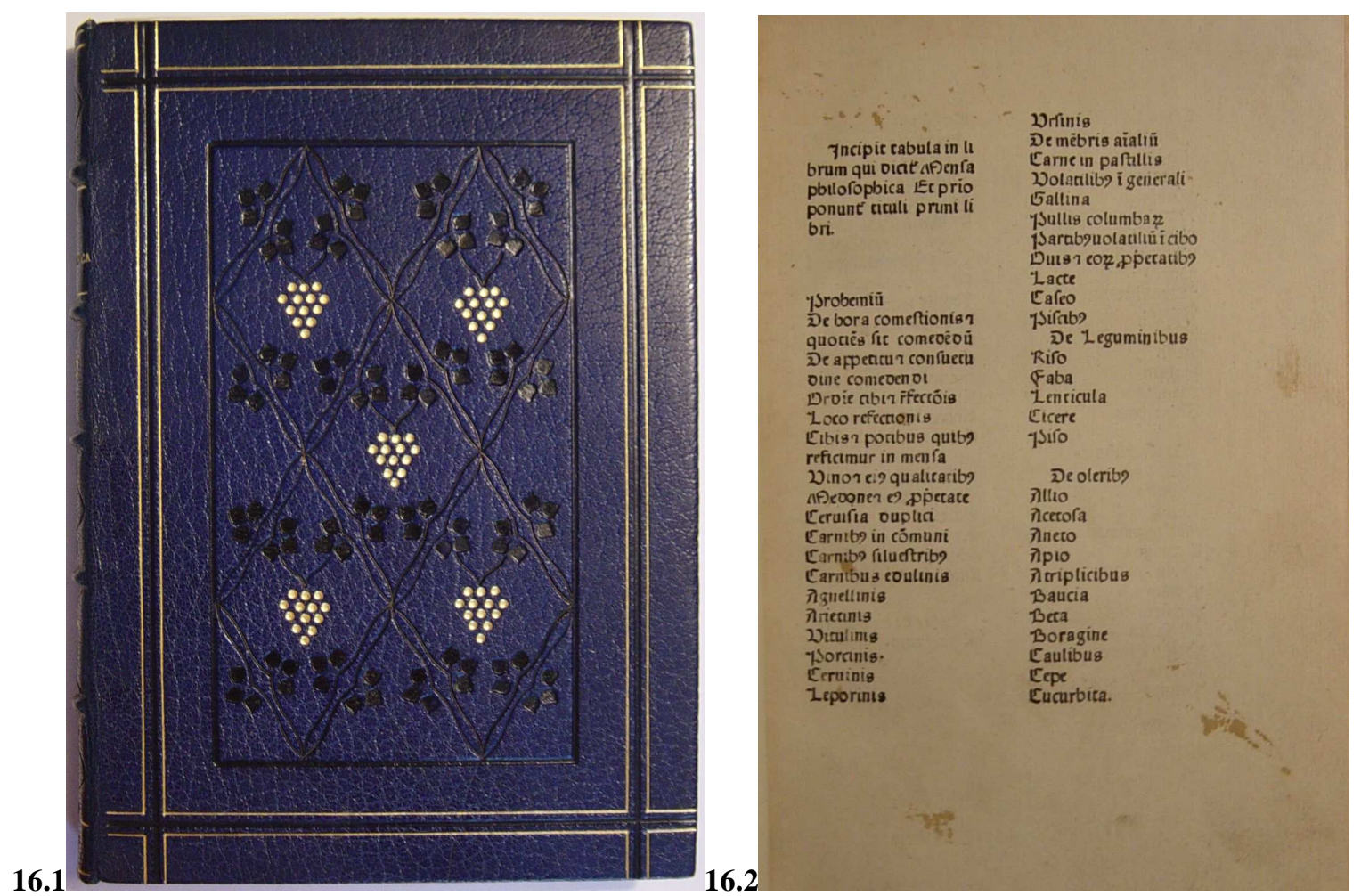

Fig. 16.1 e 16.2 - Detalhe da encadernação e da página de abertura do livro (f. 1r).

Encadernação do século XX em pleno couro azul, decorada com motivos vinícolas, corte superior dourado. Assinada: "Bound at the national library of Wales - C. Hanson". Provavelmente nesta ocasião a obra foi restaurada e o papel lavado.

Referências reportam edição de 82f., sendo a primeira branca; GW cita como impressor Johann de Paderborn e data de ca.1481.

Mensa philosophica é uma obra anônima, atríbuida a diversos autores dos séculos XII ao XIV (Michael Scotus, Theobaldus Anguilbertus ou Konrad von Halberstadt, o jovem), mas sem nenhuma comprovação de veracidade. É o caso da edição impressa em Paris por Jean Petit em 1500, onde consta "Theobaldus Anguilbertus hybernensis artium et medicinae doctor." A obra é o primeiro tratado sobre gastronomia social, discorrendo sobre como se portar à mesa, o uso correto do vinho, propriedades dos alimentos, entre outros temas. 


\section{$1483 / 1484$}

\section{7.}

\section{HIERONYMUS, Eusebius Sophronius - S. Jerônimo (ca. 347 - 419)}

\section{Vitae sanctorum patrum, sive vitas patrum.}

Veneza : Octavianus Scotus, 14 de fevereiro de 1483/1484.

[7], 243, [1]f. ; $22,7 \mathrm{~cm}$. (in $4^{\circ}$ )

Texto em latim. Acresc.: De laude et effectu virtutum. Pseudo-Macarius: Epistola ad monachos.

Assinatura: $a^{7} b-E^{8} F^{4}$

2 colunas, 46-7 linhas; tiítulo corrente; caracteres góticos; registro.

Filigrana: flechas

Procedência: Georgius Graf (ex-libris)

Rubricado com iniciais e parágrafos em vermelho. Encadernação em capas de madeira revestidas pergaminho ricamente decorada, com fechos de metal. Anotações marginais. Há três folhas brancas no início e no final que não pertencem à obra.

Assunto: Religião

Interesse vinário: Embriaguez.

Referências: Aquilon 370; Arnoult 798; BMC V 279; BSB-Ink V-256; Buffévent 269; CIBN H-126; CIH, 1695; Coll(S) 1104; Finger 543; Girard 246; Goff H-206; Graesse, III, p. 276; Hain 8599*; IBE 3173; IGI 4753; Madsen 4179; Mendes 689; Ohly-Sack 2987; Pell Ms 11713; Polain(B) 3995; Sajó-Soltész 1695; Sheppard 3645; Proctor 4573; Voull(B) 3903,3; Walsh 1788; Zehnacker 1167.

Banco de dados: CCPB 000110408-X; GW M50888; ISTC ih00206000.

Exemplares conhecidos: 127 (15 imp., 1 destr.).

Fac-símile eletrônico disponível em Verteilte digitale Inkunabelbibliothek: <http://inkunabeln.ub.uni-koeln.de/vdib-info/kleioc/ih00206000>.

Outro incunábulo na BVR: ${ }^{\circ} 5$

00008

Folha $\operatorname{lr}$ (ass. $A_{2}$ ): [ $\mathrm{D}^{2}$ ]Occafiōe ftili hoc // in opere obferuati quifquam le- // gentium aut audientium offendiculus pa // etc. 
Tabula segue até folha $7 v$ (sem numeração).

Folha $8 r($ ass $b)$ : Prologus // Incipit prologus fancti Hieronymi car // dinalis prefbyteri: in libros Uitafpatrum // fanctorum Egyptiorum. etiam eorum qui // etc.

Folha 250v (f. ccxliii): 40 linhas // Impreflfum Uenettijs per Octauianum // fcotū Modoetienfem fextodecimo ka- // lēndas Martij. M.cccc.lxxxiii. Ioanne Mocenico Inclyto Uenetia $\pi$ Duce.

Folha 251r : Incipit Regiftrum // col. 1: a // Uacat // ne occafione // etc. col. 4, final: incurrit // mo gratanti.

Folha 251v: branca
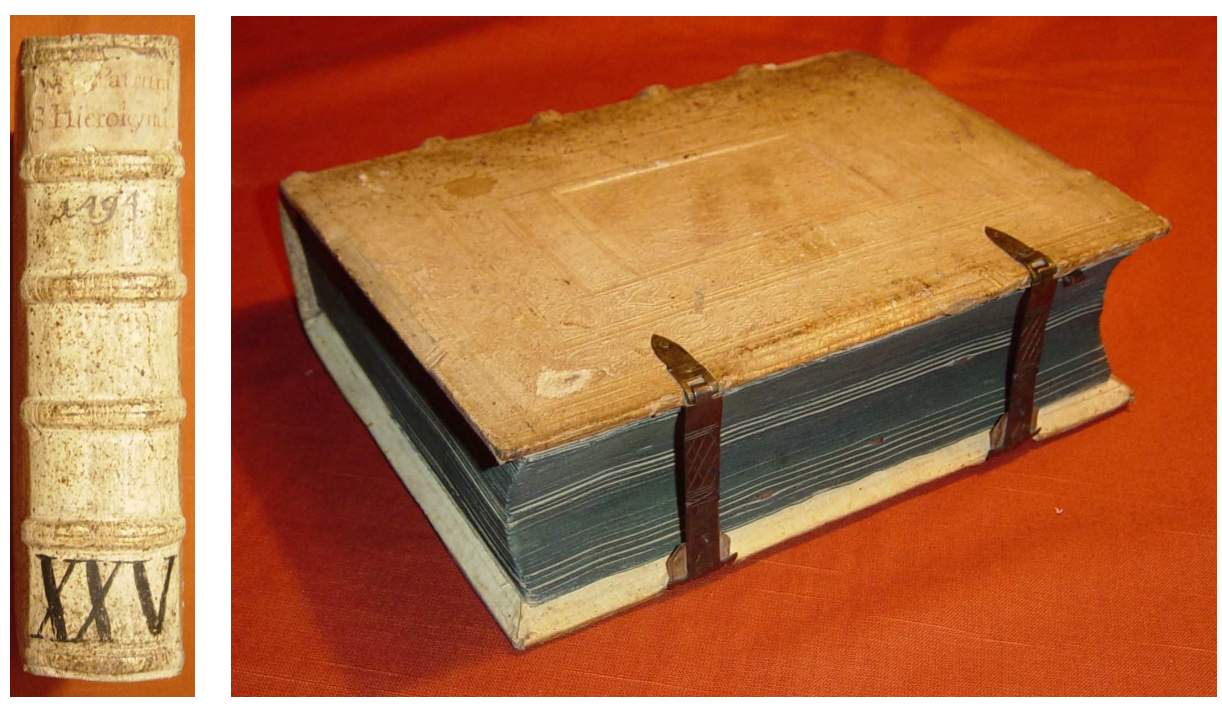

Fig. 17.1 e 17.2 - Detalhes da encadernação.

Encadernação original do século XVI, com capas de madeira revestida em couro de porco curtido ao alúmen, cortes pintados de azul, com marcadores de página em couro dourado e fechos de metal conservados. Ricamente decorada com gravação à seco, no centro de cada pasta há um painel com imagem gravada de tema religioso. Iniciais pintadas em vermelho e algumas anotações manuscritas ao longo do livro (algumas cortadas, indicando que a obra foi utilizada antes desta encadernação).

Octavianus Scotus, muito ativo em Veneza, se considerava impressor e seu nome consta como tal nos incunábulos até 1484; mas é provável que mesmo neste período as obras fossem impressas para ele; a partir desta data, não há dúvida de que ele era apenas o editor (PROCTOR, p. 301). Na BVR há duas obras editadas por ele: Metamorfosis de Ovídio (nº 36) e Opera de Horácio (nº 41). 


\section{[não depois de 1484]}

\section{8.}

\section{DURANTI, Gulielmus (1237? - 1296)}

\section{Rationale divinorum.}

Estrasburgo : [Georg Husner, não depois de outubro de 1484].

[3], Folium I-CCLXXII, [1]f. ; $21 \mathrm{~cm}$ (in $4^{\circ}$ ).

Texto em latim.

2 colunas; 46-47 linhas e tit. corr., caracteres góticos [tipo: 1:160G, 2:99G, 3:91G].

Filigranas: letra "P"

Procedência: Walter Goldwater (Ex-libris)

Encadernação com capas de madeira, restaurada (nova lombada em couro), em caixa de conservação.

Assunto: Religião

Interesse vinário: Mística do vinho.

Referências: Arnoult 564; BMC I 132; Borm 937; BSB-Ink D-345; Coll(U) 513; Ernst(Hildesheim) II,III 55; Goff D428; Günt(L) 2657; H 6489*; Hubay(Augsburg) 741; IBP 2023; IDL 1658; IGI 3634; Madsen 1473; Mittler-Kind 957; Oates 223; OhlySack 1072-1076; Péligry 321; Pell 4506; Polain(B) 1378; Proctor 590; Sack(Freiburg) 1324; Sajó-Soltész 1236; Torchet 325; Voull(B) 2401; Voull(Trier) 1498; Walsh 219; Zehnacker 819.

Banco de dados: GW 9126; ISTC id00428000.

Exemplares conhecidos: 85 (6 imp.).

03855

Folha 1r: Rationale Divinorum

Folha 1v: branca

Folha 2r: Tabula // Ifte liber dividitur // in octo libros // Prim $^{9}$ liber habet // etc.

Folha $4 r$ (n. Folium I): Prologus // Incipit rationale divinorū officio // rum guilhelmi minatenfis eccle: // fie epifcopi // ( Q )uecunq3 // in ecclesia // etc.

Folha 275v (n. Folium CCLXXII): ... Explicit ratio // nale divinorum officio // rum Impreflum argen // tine anno domini. M. // cccc. Lxxxiiii. 


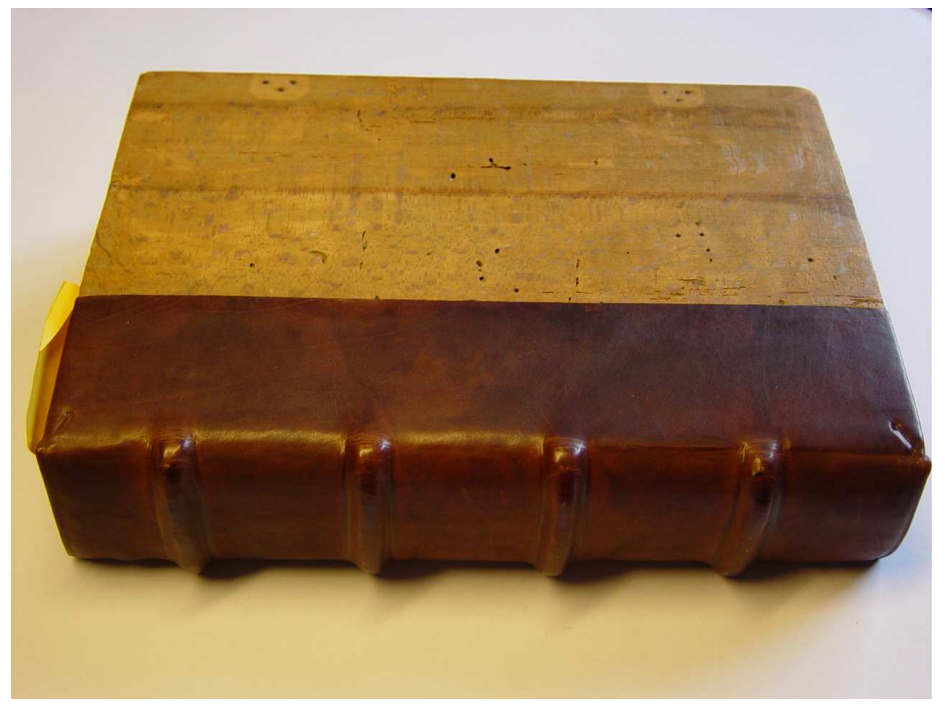

Fig. 18.1 - Detalhe da encadernação.
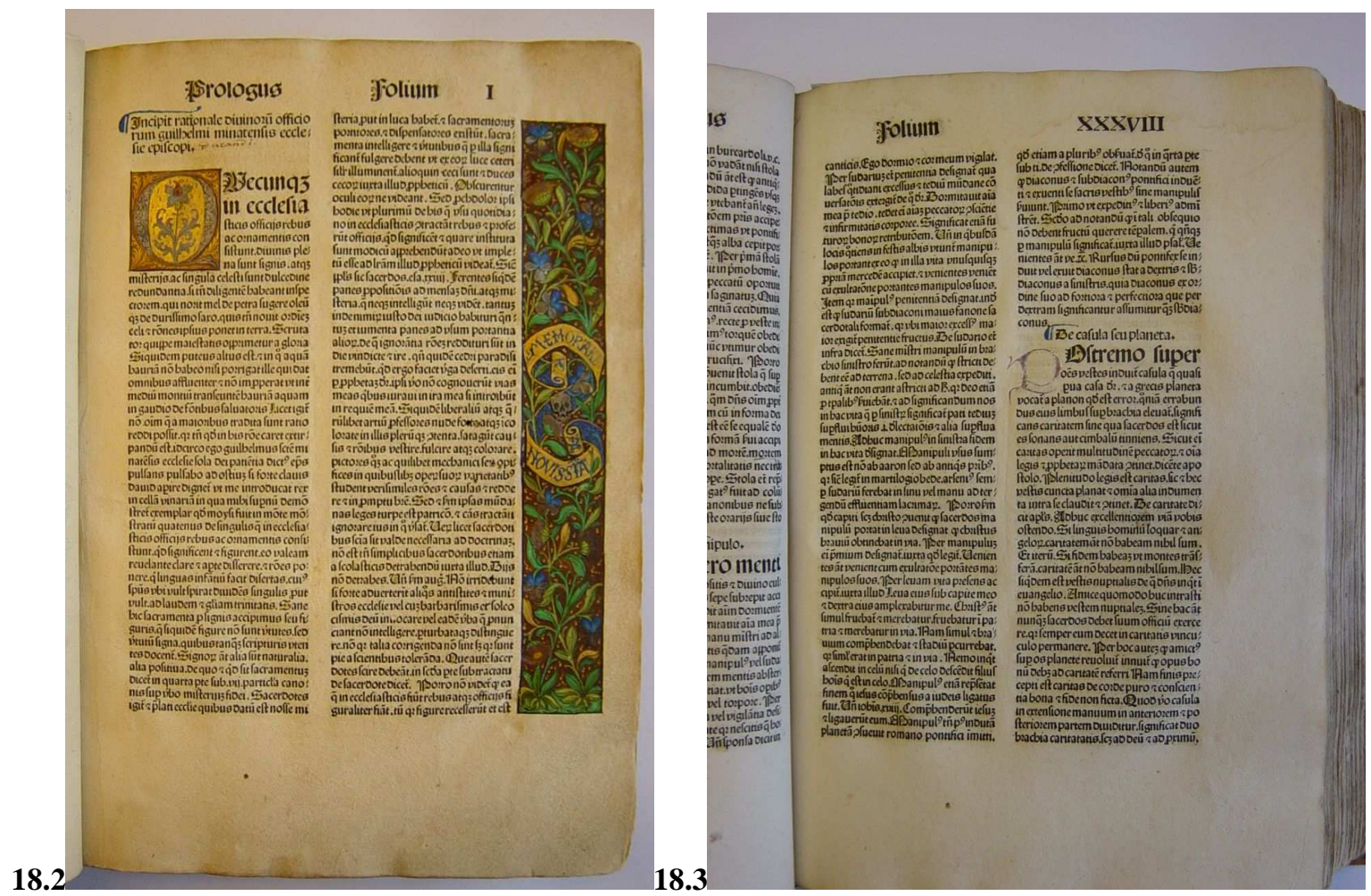

Fig. 18.2 e 18.3 - Página iluminada de abertura da texto (f. 4r) e Folium XXXVIII (f. 41r)

Rationale Divinorum possui nove capitulares iluminadas ${ }^{37}$ na abertura de cada livro e uma bela barra lateral no primeiro folium. O uso de diversas cores e do dourado,

\footnotetext{
${ }^{37}$ As capitulares estão nos Folium II(v), XXIIII(v), XXXIIII(v), XLVII(v), CXIIII(v), CCXXXVIII (r),

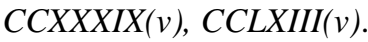


demonstram a importância do trabalho de iluminura; além disso encontramos iniciais e marcas de parágrafos se alternando entre vermelho e azul por todo o texto.

Rationale Divinorum é um incunábulo iluminado, não ricamente como os famosos Livros de Horas manuscritos e iluminados, mas com algumas iniciais iluminadas e decorações marginais. Em número não pequeno, destinavam-se certamente a público mais exigente e de maiores posses.

A encadernação original do século XV foi restaurada, conservando as pastas de madeira originais e sua estrutura, mas com a confecção de nova lombada em couro; os fechos posteriores foram conservados. Folhas em branco com anotações, pertencentes a encadernação anterior, foram conservadas tanto no inicio como no fim da obra; marcas de cola indicam que estas folhas deviam estar aderidas à capa antes do restauro, mas novas folhas de guarda foram acrescentadas para proteger as folhas originais.

Guillelmus Duranti, cônego francês, jurista e teólogo, foi educado na Universidade de Bolonha. Serviu a vários Papas do século XIII com diferentes atribuições. Tornou-se Bispo de Mende em 1286, ano em que escreveu Rationale divinorum officiorum, exaustivo tratado da natureza e do simbolismo da Liturgia Católica Romana. A importância dada à obra se torna evidente quando a pesquisa das edições do século $\mathrm{XV}$, mostra que foi uma das primeiras obras impressas e teve 45 edições até 1500. A primeira edição foi impressa em Mainz por Peter Schöffer e Johann Fust em 1459, e praticamente todos os exemplares conhecidos são em velino. ${ }^{38}$

No capitulo nove do Livro IV, Duranti discorre sobre o vinho de missa.

\footnotetext{
${ }^{38}$ ISTC id00403000.
} 


\section{5}

19.

LIVIUS, Titus (ca. 59 a.C. - 17 d.C.)

\section{Historia romana decades.}

Veneza : Andreas Torresamus, de Asula, et Soccii [Bartholomaeus de Blavis], 13 de agosto de 1485 .

[371]f. ; 34,5 cm (in fol.)

Texto em italiano. Acrescentado de Leonardus Brunus Aretinus: De primo bello Punico.

Assinatura: A-B ${ }^{10}$ a-o ${ }^{8} \mathrm{p}^{6} \mathrm{q}-\mathrm{ff}^{8} \mathrm{gg}^{6} \mathrm{hh}-11^{8} \mathrm{rr}^{8} \mathrm{~mm}-\mathrm{qq}^{8} \mathrm{ss}^{8} \mathrm{tt}^{10} \mathrm{vv}^{8} \mathrm{xx}^{9}$

2 colunas; 63 linhas, tit. corr.; caracteres romanos; reclamos (apenas no verso); espaço vazios para as iniciais e com letras-guias.

Filigrana: cruz

Iniciais manuscritas em marrom. Encadernação moderna com capas de madeira e lombada em couro.

Assunto: História

Interesse vinário: História do vinho.

Referências: BMC V 308; Brunet, III, p.1112; CIBN L-193; Goff L-254; Graesse IV, p.234; Hain 10147; IGI 5785; Madsen 2501; Oates 1863; Ohly-Sack 1814; Pell Ms 7222 (7163); Proctor,4708; Sajó-Soltész 2083; Sheppard 3777; Walsh 1886.

Banco de dados: GW M18523; ISTC il00254000.

Exemplares conhecidos: 34 (11 imp.).

Outros incunábulos na BVR: $\mathrm{n}^{\circ} 9$

02392

Folha 1: branca

Folha 2 r (ass. $\left.A_{i i}\right), 1^{a}$ col.: Tauola dele rubriche del primo libro dela pri // ma de cade Tito Liuio padoano hiftorico. // [ ${ }^{3}$ ]Ncomincia el phemio del primo libro di // Tito Liuio excellētiflimo auctore \& iudi // etc.

Folha $21 r$ (ass. a), $1^{a}$ col.: INCOMENZA EL PROEMIO DELA PRI // ma Deca de Tito liuio excellētiflimo auctore \& // iudice de Padua cittadino Romano elqual racōta // le 
hiftorie del populo Romano. // $\left(\mathrm{I}^{7}\right) \mathrm{O}$ NON SO al tutto bene certamē // te fe faro alcuna utilitade fcriuēdo le // etc.

Folha 346v, $2^{a}$ col.: (55 linhas) // Finifcono le Deche: cioe la pma tertia \& quar // ta de Tito Liuio Paduano hiftorico digniflimo: // imprefle in Venetia per Bartholomeo de Alexan // dria \& Andrea de Afula cōpagni: nel. M.CCCC // LXXXV.adi.XIII.de Augufto.

Folha 347r (ass. uu): CAPITVLO PRIMO // $1^{a}$ col.: Prologo fopra el libro chiamato de la guerra // punica: la quale fuo tra Romani \& Carthagine- // fi compolto da lo digniflimo oratore \& hiftorio // etc.

Folha 363v, $2^{a}$ col.: (60 linhas) // galli cifalpini al tutto domati uēnero in potefta // del po. Ro. Et non molto dapoi tolto loro poffel// fione conftrecti furo abandonare el paefe.

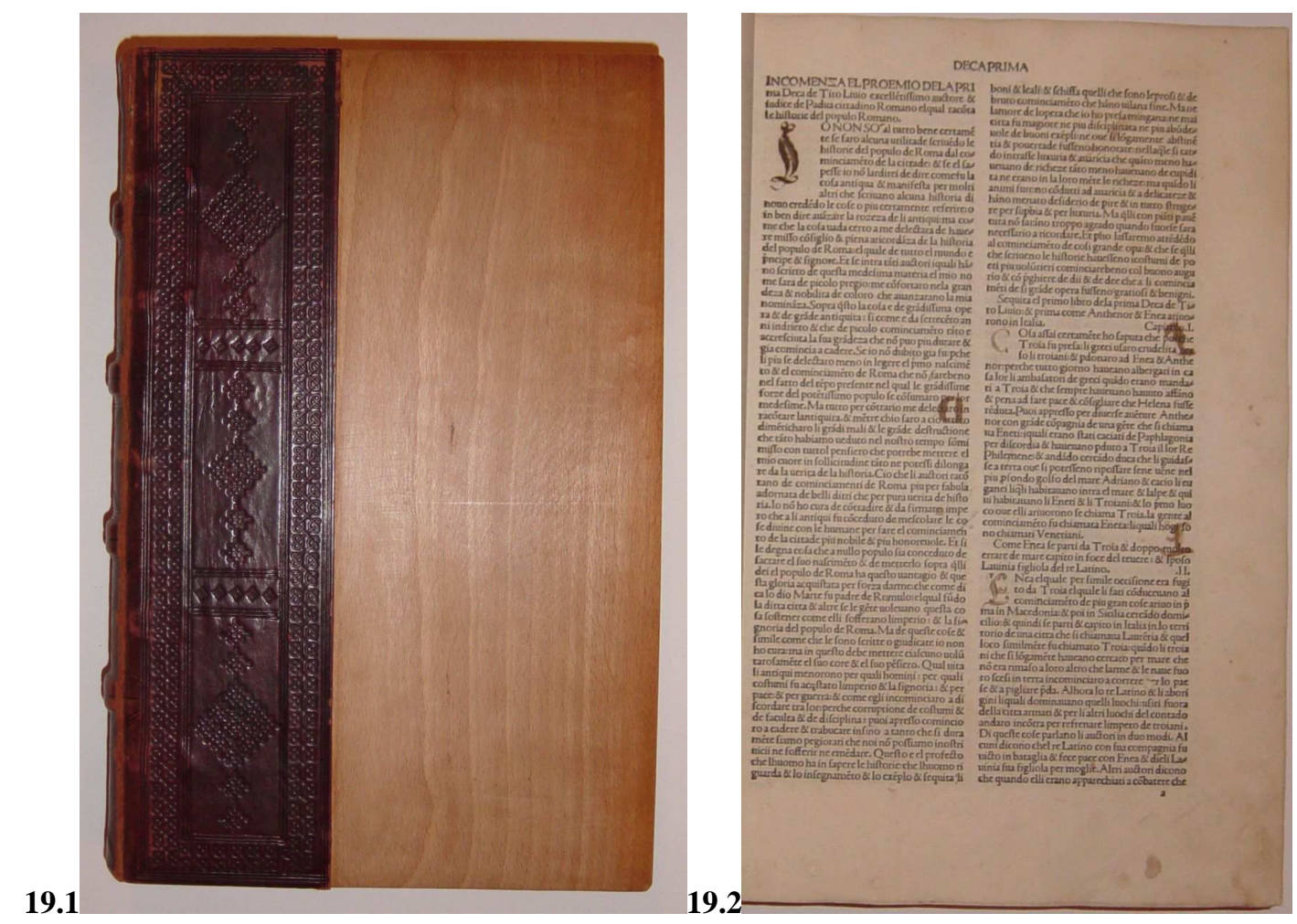

Fig. 19.1 e 19.2 - Detalhe da encadernação e página de abertura das Decadas (f. 21r).

Exemplar restaurado, últimas folhas com margens enxertadas, folhas limpas, sem anotações marginais; caderno com assinatura rr encontra-se deslocado, vindo após caderno 11. As iniciais em marrom presentes em parte do texto são amadoras, e possivelmente foram feitas por um de seus proprietários. A encadernação, moderna com pastas de madeira e lombada em couro com decoração a seco, é similar às da época (como algumas encontradas na coleção) e pode ser cópia da encadernação original perdida, mas não há registros que confirmem esta suposição. 
Andreas Torresanus trabalhou sempre em Venezza como impressor, sozinho e também em sociedade com outros impressores; nesta obra a parceria foi com Barthomoleaus de Blavis; no final do século, dedicou-se mais ao trabalho de editor do que ao de impressor. 


\section{[não antes de 1485]}

20.

HEROLT, Johannes (ca. 1380 - 1468)

\section{Líber discipuli de eruditione Christifidelium.}

[Basiléia : Johann Amerbach, não antes de 1485].

[168]f. ; $28 \mathrm{~cm}$ (in fol.)

Texto em latim.

Assinatura: $a^{10} b-t^{8} j^{6} z^{8}$

2 colunas; 43 linhas, tít. corr.; caracteres góticos [tipo: 1:185G, 3:92G]; letra-guia e espaço para iniciais.

Filigranas: letra "P"

Procedência: The Paolino Berli Collection (ex-libris)

Encadernação em couro e percalina. Anotações marginais, rubricado e com iniciais em vermelho.

Assunto: Religião

Interesse vinário: Embriaguez

Referências: Arnoult 771; BMC III 748; Borm 1302; BSB-Ink H-126; Finger 518; Goff H94; Hain 8519* (incl H 8520*); Hanssler, p. 386; IBP 2732; IDL 2252; Madsen 1937; Mendes 596; Polain(B) 1915; Proctor 7616; Richard 253; Sack(Freiburg) 1803; SajóSoltész 1650; Schmitt I 484,5; ; Voull(B) 484,5; Voull(Trier) 194.

Banco de dados: GW 12329; ISTC ih00094000.

Exemplares conhecidos: 40 (7 imp., 1 vend.).

00011

Folha 1: branca

Folha $2 r$ (ass. $a_{2}$ ): Depreceptis // (coluna 1) Liber difcipuli de eruditiōe chrifti fi- // deliū incipt. De pceptל⿳亠丷厂 generali. // $\left(\mathrm{S}^{6}\right)$ Ivis // as vi- // tā îgredi Pua // etc.

Folha 153v, $2^{a}$ coluna: 29 linhas // Tractatus de feptem donis fpūflan- // cti explicit. Et per כequēs totus liber // difcipuli de eruditione xpi fidelium.

Folha 154: branca

Folha 155: branca 
Folha $156 r$ (ass. $j_{2}$ ): Themata dñicarū totius anni // $1^{\mathrm{a}}$ col.: Tabula $\mathbf{P}$ fermonibus de tempore ex // hoc libro colligendis. // Domīca pma aduendtus dñi. // $\left(\mathrm{e}^{5}\right)$ Cce rextu // etc.

Tabulas seguem até folha $168 \mathrm{r}$

Folha 168v: branca

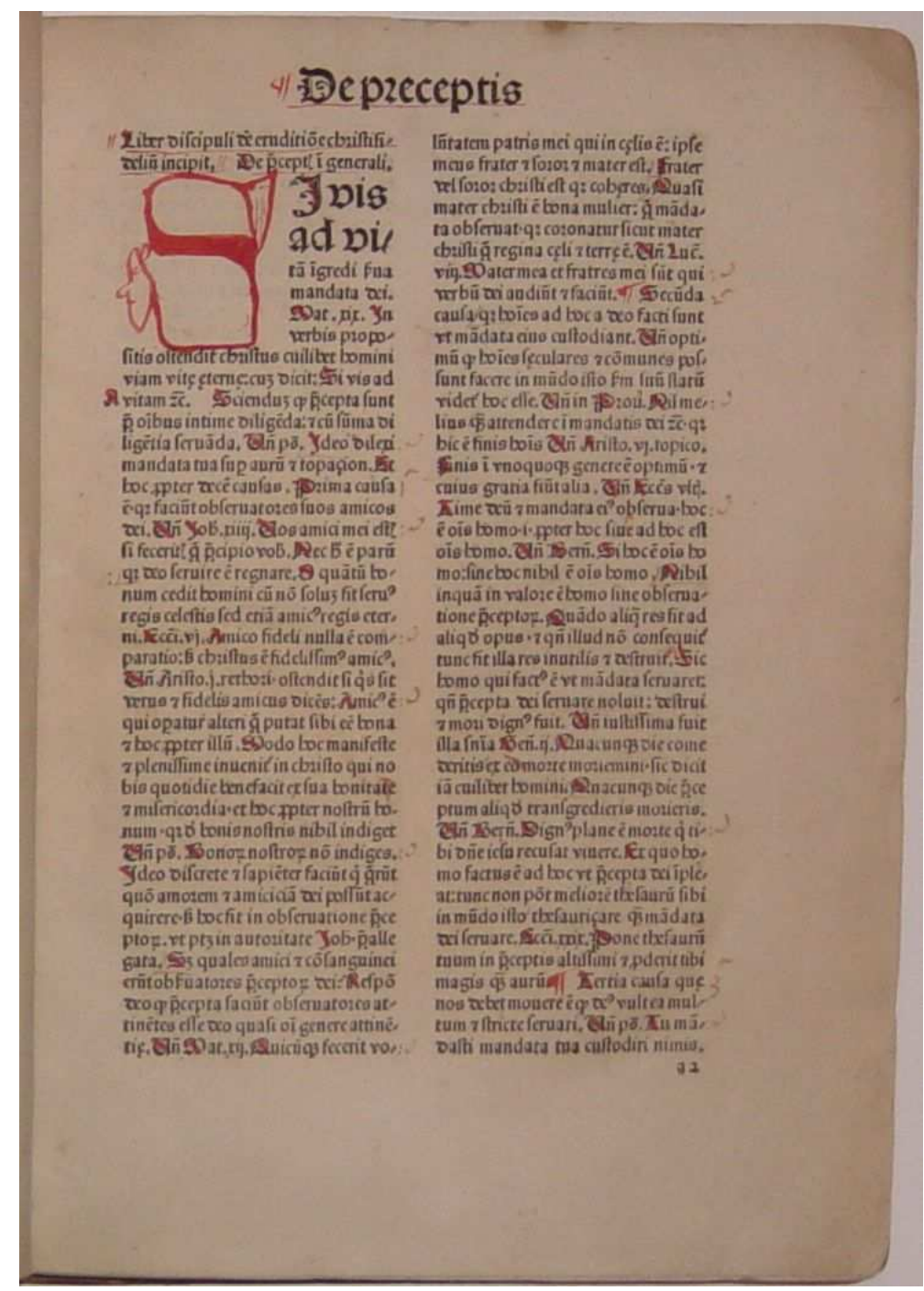

Fig. 20 - página de abertura do texto (f. 1r).

Encadernação em couro (lombada e cantos) e percalina, provavelmente do final do séc. XVIII. Texto rubricado e com iniciais pintadas em vermelho, diversas anotações marginais e boas margens. As folhas brancas (f.154 e f.155) possuem texto manuscrito antigo e presença de reparos antigos amarelados pelo tempo.

Johannes Amerbach (1513†) um dos mais importantes impressores da Basiléia, homem culto, educado em Sorbonne, foi também comerciante e editor, com vários 
tipográfos imprimindo para ele. Este volume é belo exemplo de seu trabalho como impressor, sendo conhecidos poucos exemplares completos da edição.

Nesta obra do teólogo dominicano alemão Johannes Herolt, que provavelmente se destinava aos pregadores, há vários tópicos com temática vinária, como: "A embriaguez é muito perigosa", "A abstinência no comer e no beber prolonga a vida", "a abstinência no comer e o beber estimula a castidade no homem" etc. 


\section{6}

\section{1.}

CRESCENTIIS, Petrus de (ca.1230 - 1320)

\section{Ruralia commoda $=$ Opus ruralium commodorum.}

Estrasburgo : [impressor de 1483 Jordanus de Quedlinburg (Georg Husner)], 9 de março de 1486.

[148]f. ; 28,7 cm (in fol.)

Texto em latim.

Assinatura: $(2,3)^{6} a^{8} b-y^{6} z^{8}$

2 colunas; 46 linhas e título corrente; caracteres góticos [tipos: 1:160G, 2:99G, 3:91G]; letra-guia.

Filigranas: letra "P"

Procedência: The Horticultural Society of New York (Ex-libris)

Exemplar com rubricas e encadernação do século XVI.

Assunto: Agricultura

Interesse vinário: Viticultura

Referências: BMC I 134; Borm 861; Brunet II p.415-6; BSB-Ink C-697; CIBN C670; Coll(S) 343; Coll(U) 1183; Deckert 261; Goff C968; Graesse II p.299, Günt(L) 2665; Hain 5831*; Henssler p.208; Hubay(Augsburg) 654; Hubay(Eichstätt) 319; IBP 1806; IGI 3264; Klebs 310.5; Madsen 1293, T20; Neveu 207; Ohly-Sack 976-977; Péligry 291; Pell Ms 9329 (9152); Polain(B) 3101; Proctor 602; Sajó-Soltész 1118; Sheppard 466; Simon BBI p.35; Voull(B) 2410; Walsh 229; Wilhelmi 206; Zehnacker 742;

Banco de dados: GW 07824; ISTC ic00968000

Exemplares conhecidos: 95 (4 imp., 1 frag., 1 destr., 3 perd.).

Fac-símile eletrônico disponível em Verteilte digitale Inkunabelbibliothek: <http://inkunabeln.ub.uni-koeln.de/vdib-info/kleioc/ic00968000>.

Outros incunábulos na BVR: ${ }^{\circ} 1$ e n ${ }^{\circ} 28$

Folha 1r: Opus rutalium com // modorum Petri de // crefcentiis.

Folha 1v: branca 
Folha 2 r (ass. 2), $1^{a}$ col.: Petri de crefcentiis ciuis Bo- // nonienfis epiftola commodorum // ruralium // In nomine fancte et indiuidue // trinitatis Amen // ( $\left.\mathrm{v}^{6}\right)$ Enerabili in // chrifto patri 7 dño Ipū- // etc.

Folha $7 r$ (ass. a), $1^{a}$ col.: Incipit liber primus de locis // habitabilibus eligendis. Et de cu- // riis et domibus et his que habi- // tationi funt in rure neceffaria . et // primo De cognitione bonitatis lo // ci habitabilis in cōmuni // $\left(\mathrm{q} \mathrm{Q}^{5}\right) \mathrm{Uoniā}$ cult ${ }^{9} / /$ raris prop- // ter continuos eius labo // etc.

Folha 147r, $2^{a}$ col.: (25 linhas) // Finis libri ruralium cōmodo $\pi$ Pe// tri de crefcentiis hoc induftriofo caracteri // fandi ftilo ad cuncto $\pi$ vtilitatē omnipotē // tis dei fuffragio impreffum eft argentine. // Anno domini. Mccclxxxvi. Finitum qn // ta feria ante feftum fancti Gregorii.

Folha 148: branca
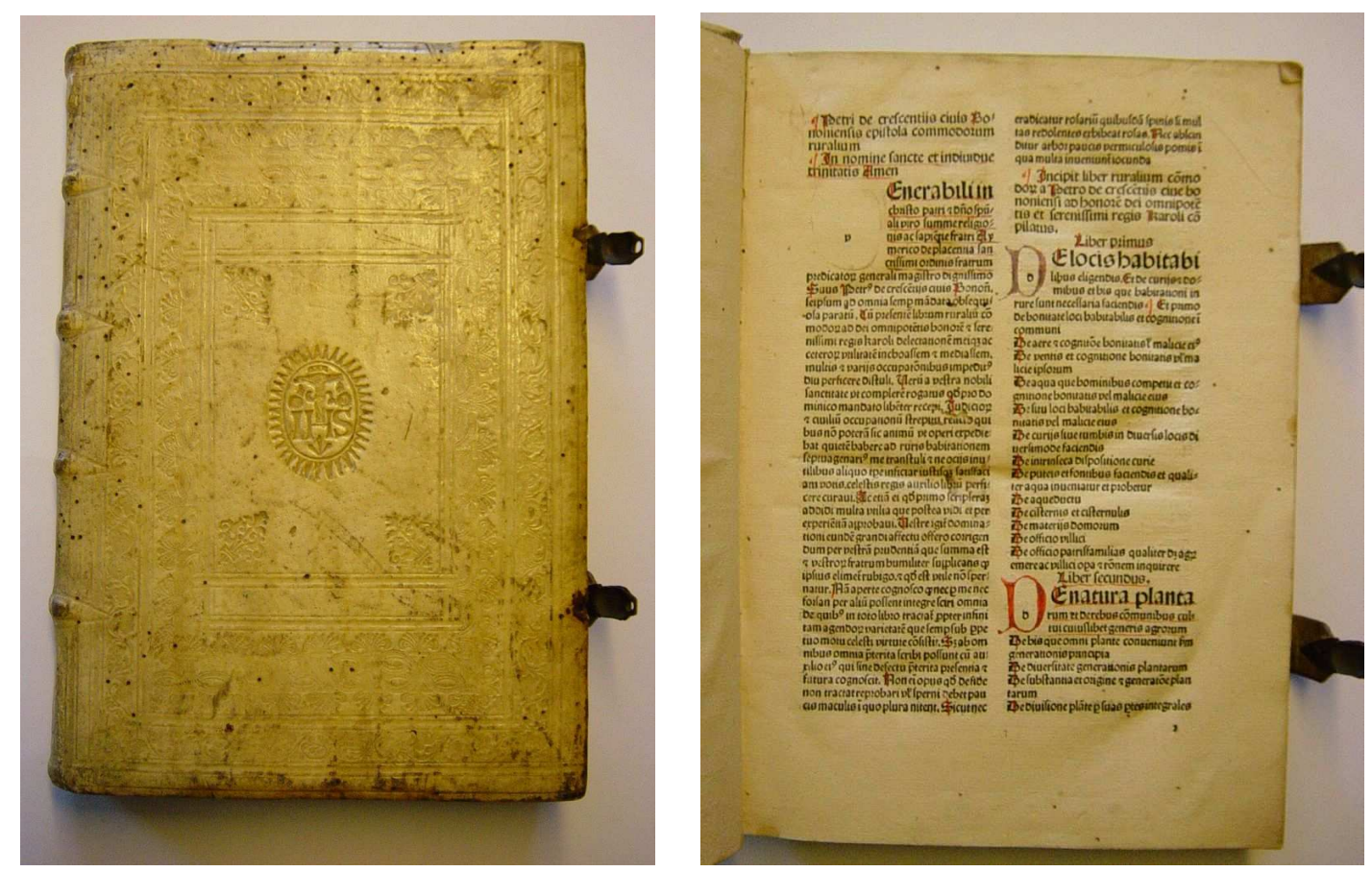

Fig. 21.1 e 21.2 - Detalhe da encadernação e página de abertura do texto (f.2r).

Encadernação do século XVI, com pastas de madeira revestida de couro de porco, decorada com ferros a seco e painéis com temas religiosos no centro de ambas as pastas, conservação parcial dos fechos (perda do botão). Exemplar limpo, sem anotações; início da obra decorada com iniciais em vermelhos. 


\section{[não depois de 1487]}

\section{2.}

AUGUSTINUS, Aurelius, S. Agostinho (354-430)

\section{Sermones sancti augustini ad heremitas.}

[Estrasburgo, Johann Prüss, não depois de 1487].

[108]f. ; $19 \mathrm{~cm}\left(\right.$ in $\left.4^{\circ}\right)$.

Texto em latim.

Assinatura: A-M ${ }^{8} \mathrm{~N}-\mathrm{O}^{6}$

2 colunas; 34 linhas; caracteres góticos; espaço para iniciais.

Filigranas: coroa, cabeça de boi, letra "P"

Iniciais pintadas em vermelho, azul e prata. Encadernação em pleno couro, corte vermelho, inscrições na guarda, folha de rosto e marginais em algumas páginas. Com estojo de proteção.

Assunto: Religião

Interesse vinário: Embriaguez

Referências Bibliográficas: Arnoult 165; BMC I 125; Borm 280; BSB-Ink A-921 ; Coll(S) 1151; Coll(U) 204; Ernst(Hildesheim) II,III 20; Girard 50; Goff A1314 ; Günt(L) 2630; Hain 1997*; Hummel-Wilhelmi 83; IBE 129; IBP 673; IDL 570 ; IGI 1034; Madsen 448; Neveu 70; Oates 221; Ohly-Sack 323, 324; Pad-Ink 73; Parguez 110; Pellechet 1508; Polain(B) 406; Proctor 741; Sack(Freiburg) 384; Sajó-Soltész 408; Simon BBI p.105; Voull(B) 2365; Voull(Trier) 1606; Wilhelmi 84; Walsh 194; Zehnacker 315.

Banco de dados: GW 03002; ISTC is01314000.

Exemplares conhecidos: 130 (7 imp., 1 destr.).

00010

Folha 1r: Sermones fan // cti Auguftini ad // heremitas.

Folha 2 r (ass. $A_{2}$ ): Tabula // Incipit tabula fermonu3 fancti Auguftini epifcopi at do // ctoris ecclefie. Ad heremitas // etc.

Folha $3 r$ (ass. $A_{3}$ ): Sermo I. // Incipiunt fer- // mones fancti Auguftini ad // heremitas T nōnulliad facer // dotes fuos: 7 ad aliqs alios. // etc. 
Folha 108r, $2^{a}$ col.: margaritas vobis de paradi // fi patria prouidentes nullam // aliam in hoc feculo mercedeз // opramus. Quam nos dona- // redignetur chriftus iefus. q // viuit er regnat deus per om- // nia fecula feculorum. Amen. // Explicit.

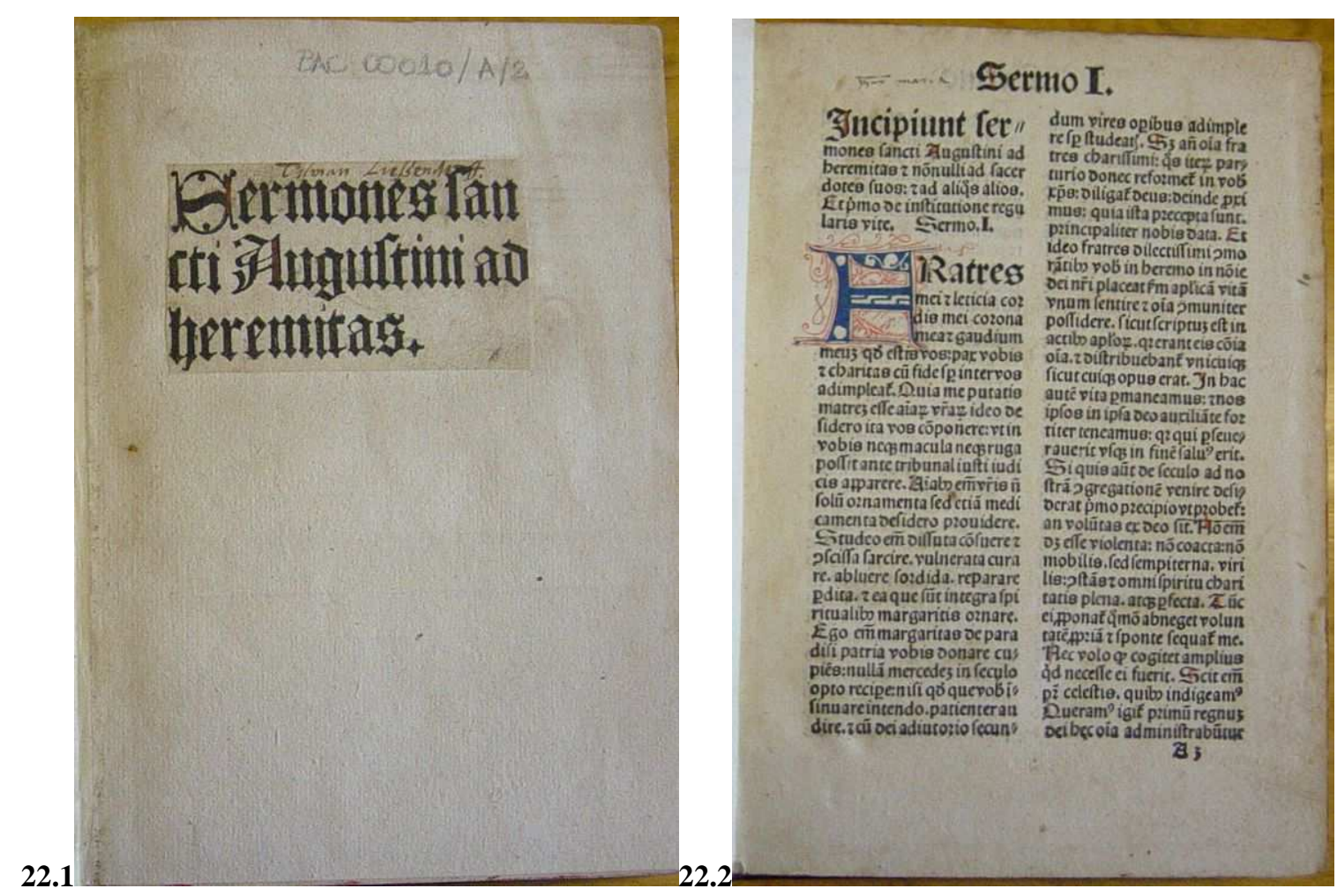

Fig. 22.1 - Página de abertura da obras (título original recortado e aplicado sobre folha nova).

Fig. 22.2 - Página de abertura dos sermões (f. 3r).

Exemplar com belas iniciais pintadas em vermelho, azul e prata na abertura dos sermões com as cores se alternando. Inscrições na guarda, folha de rosto e marginais em algumas páginas.

A encadernação é moderna e segue o estilo das encadernações antigas da época; na guarda há uma anotação a lápis: "save this and use as front endpaper" (provável orientação dada ao encadernador-restaurador), e o texto da folha de abertura foi recortado e aplicado sobre uma folha nova. Com estojo de proteção.

Johannes Prüss foi impressor de destaque em Estrasburgo onde atuou de 1483 até a sua morte em 1510; no século XV imprimiu mais de cento e cinquenta obras.

Aurelius Agostinus nasceu em Tagasta, cidade da Numídia, de origem burguesa; apesar de sua mãe ser cristã fervorosa, ao ir para Cartago a fim de aperfeiçoar seus estudos, desvia-se moralmente deixando-se levar pela luxúria. Depois da conversão em 386, vende todos os haveres e, distribuído o dinheiro entre os pobres, funda um mosteiro numa das 
suas propriedades alienadas. Ordenou-se padre em 391 e sagrou-se bispo em 395, governando a igreja de Hipona até à morte, quando tinha setenta e cinco anos de idade. Desde sua conversão dedicou-se aos estudos da Sagrada Escritura, da teologia e filosofia, legando-nos farta produção.

Este conjunto de sermões de S. Agostinho abrange muitos aspectos da vida monástica, sendo de especial interesse os dedicados a assuntos médicos, alimentação e bebida; o sermão 33, De superfluo potu, é das mais vibrantes censuras à embriaguez. 


\section{8}

\section{3.}

\section{AVIENUS, Rufus Festus}

Arati phaenomena. Ed. Victor Pisanus. Acresc. Dionysius Periegetes: De situ orbis (Trad. Avienus). Avienus: Ora maritima. Aratus: Phaenomena (Trad. Germanicus, com comentário). Aratus: Phaenomena (Trad. Cicero). Quintus Serenus Sammonicus: Carmen medicinale.

Veneza: Antonis de Strata de Cremona, 1488.

[120]f. ; $21 \mathrm{~cm}\left(\right.$ in $\left.4^{\circ}\right)$

Texto em latim.

Assinatura: $a^{10} b-o^{8} p^{6}$

38-37 linhas; caracteres romanos; letras-guia.

Xilografia: ilustrações.

Filigranas: balança, cabeça de boi.

Procedência: Bibliotheca Broxbourniana J.P.W.E. (Ex-libris)

Exemplar com iniciais pintadas em vermelho, azul e verde e encadernação moderna em pleno couro.

Assunto: Medicina.

Interesse vinário: Vinho como remédio.

Referências: Arnoult 182; BMC V 294; BN-RJ 15; Brunet I p.587; BSB-Ink A-969 CIBN A-495; Delisle 204; Essling 431; GfT 2440; Goff A1432; Graesse I, p. 264; Günt(L) 3735; Hain 2224*; Hubay(Augsburg) 247; IBE 671; IBP 721; IDL 602; IGI 1131; Klebs 137.1; Madsen 480; Neveu 74; Oates 1832, 1833; Pell 1673; Polain(B) 445; Proctor 4593; Sack(Freiburg) 420; Sander 718; Sheppard 3709, 3710, 3711; Simon BB I, p.143; Voull(B) 3916; Walsh 1847, 1848, 1849; Zehnacker 337.

Banco de dados: CCPB 000107906-9; GW 03131; ISTC ia01432000

Exemplares conhecidos: 137 (28 imp.). 
Folha 2 (ass. $a_{i i}$ ): Victor pifanus Magnifico ac fingularis prudentiæ uiro // Paulo pifano fenatori Veneto.S.P.D. // Quum mecum reputarem omnes mentis inftitutiones: atq3 // etc.

Folha 4 (ass. $\left.a_{i i i i}\right)$ : RVFVS FESTVS AVIENIVS .VC. FLAVIANO MYR // MEICO . VC. SVO SALVTEM // $\left(\mathrm{q} \mathrm{Q}^{6}\right)$ Va uenit aufonias auftro duce poenus as oras // etc.

Folha 11 (ass. b): Cornipedis fimulant non hic equus integer artus // etc.

Folha 57r: (36 linhas) // RVFI FESTI AVIENII OPERA FINIVNT

Folha 57v: branca

Folha 58: branca

Folha 59r (ass. h): Fragmentū arati phænomenon per germanicum in latinū // conuerfi cum cōmento nuper in ficilia repertum. // $\left(\mathrm{A}^{5}\right)$ Ratus quidem athenodori patris filius fuit: ma // Folha 98v: M. TVLII CICERONIS FRAGMENTVM ARATI // PHAENOMENON. // etc. Folha 105r: QVINTI SERENI MEDICINAE LIBER. // PROHEMIVM. // etc.

Folha 120r: (25 linhas) // Liber medicinalis quinti fereni finit. // Hoc opus impreflum Venetiis arte \& Antonii de // ftrata Cremonenfis. Anno falutis. M.cccclxxxviii. octauo ca // lendas nouembres. // Regiftrum. // a.b.c.d.e.f.g.h.i.k.l.m.n.o.p. Omnes funt quaterni præter // a quinternum.

Folha 120v: Victor pifanus ad paulum pifanum in poftremo opere cō- // monitio. // (...) // ut imprefforem hortarer artificem: ne ferenum medicū aftro // nomo arato connectere dubitaret. Vale.

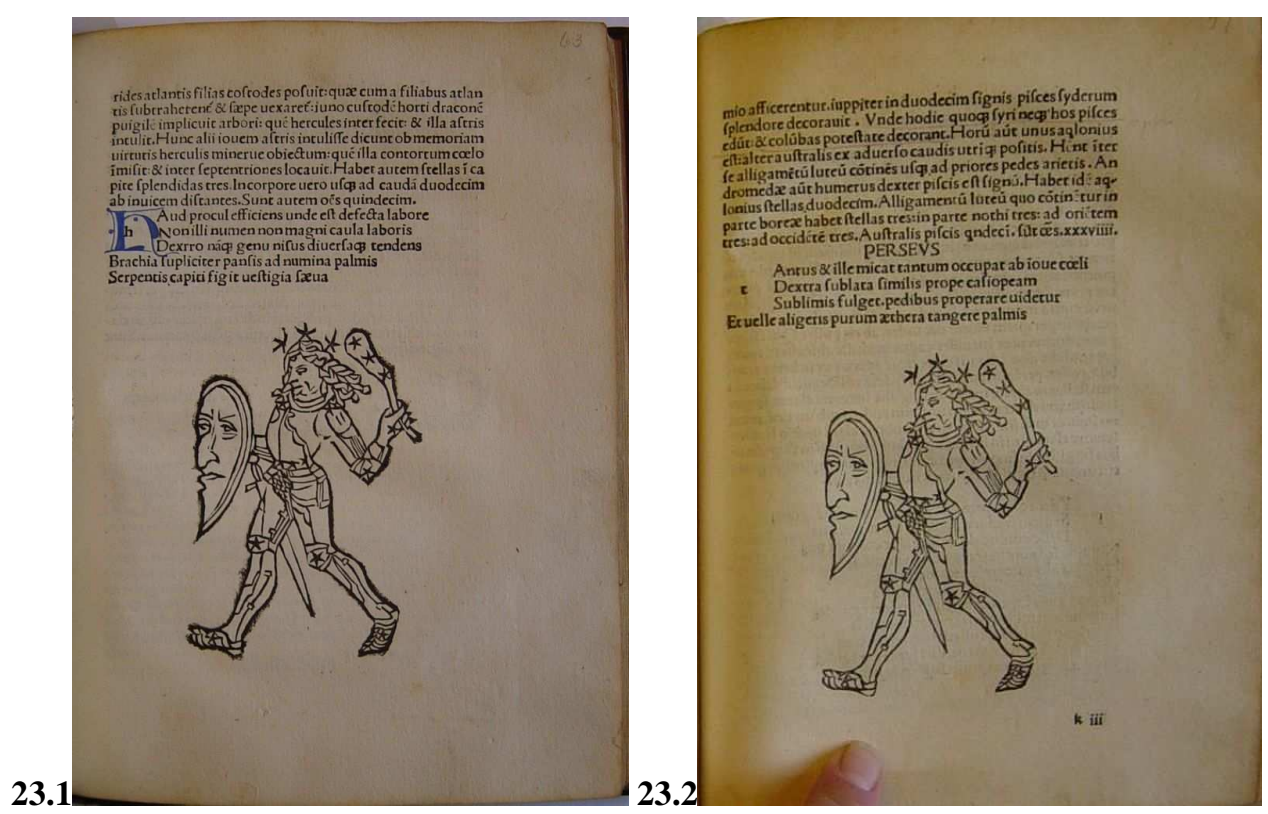

Fig. 233.1 e 23.2 - A mesma gravura em duas páginas diferentes representando personagens distintos. Pode-se observar também que somente a inicial da página à esquerda está pintada a mão. 
Exemplar limpo sem anotações, com iniciais ao longo do texto se alternando em vermelho, azul e verde (somente algumas folhas não são decoradas). De acordo com algumas referências, o último caderno deveria ter oito folhas, sendo brancas as duas finais.. A encadernação é moderna em pleno marroquino marrom, decorada com fios e delicado florão gravados a seco nas pastas e na lombada, onde apenas as inscrições estão em dourado. O texto é ricamente ilustrado com graciosas xilografias representando cenas mitológicas e os signos do zodíaco e somente um dos blocos xilográficos se repete (fig. 22.1 e 22.2) — este é o incunábulo ilustrado mais antigo da coleção Reppucci.

Este volume compõe-se de várias obras, mas seu interesse vinário se encontra apenas na última, que possui 16 folhas: Carmen medicinale, pequeno tratado de medicina, Quintus Serenus Sammonicus (séc. II-III), aconselha o uso do vinho como remédio para dores de dente, indigestão, etc. 


\section{4.}

GESTA ROMANORUM CUM APPLICATIONIBUS MORALISARIS AC MISTICIS.

[Estrasburgo : Johann (Reinhard) Gruninger], 15 de janeiro de 1488.

[1], 93, [7]f. ; 39,8 cm (in fol.).

Texto em latim.

2 colunas; 50-51 linhas; caracteres góticos.

Impresso em preto com.

Assinatura: $a-b^{8} c^{6} d^{8} e^{6} f^{8} g^{6} h^{8} i^{6} k^{8} l^{6} m-n^{8}[1] o^{6}$

Filigranas: cabeça de boi, vaso.

Exemplar com inicial manuscrita em vermelho (f.1) e encadernação alemã de época.

Assunto: História.

Interesse vinário: Embriaguez, história do vinho, viticultura.

Referências Bibliográficas: Arnoult 699; Borm 1154; Brunet II p.1571; BSB-Ink G209; CIH 1428; Ernst(Hildesheim) I,I 210; GfT 2157; Goff G-291; Graesse III p.74; Hain 7745*; IBE 2660; IBP 2400; IJL 150; Madsen 1733; Oates 182; Pell 5254; Polain(B) 1651; Proctor 450; Sack(Freiburg) 1569; Sajó-Soltész 1428; Sheppard 362; Voull(Trier) 1410; Voull(B) 2277; Walsh 163; Zehnacker 982.

Banco de dados: CCPB 000109895-0; GW 10896; ISTC ig 00291000.

Exemplares conhecidos: 49 (6 imp.).

Fac-símile eletrônico disponível em Verteilte digitale Inkunabelbibliothek: <http://inkunabeln.ub.uni-koeln.de/vdib-info/kleioc/ig00291000>.

02553

Folha 1r: Gefta rhomano $\pi$ cū // applicationibus mo // ralifatis ac mifticis.

Folha 1v: branca

Folha $2 r$ (ass. $a_{2}$ ): Folium Primum // Ex geftis rhoma- // norum hiftorie notabiles de viciis vtu // tribufq3 tractātes cū applicationibכ mo // ralifatis myfticis incipiūt feliciter. // etc.

Folha 94 r (n. Folium XCIII), $2^{a}$ col.: (39 linhas) // Ex geftis romanorū cum pluribכ ap // plicatis hiftoriis de virtutibuכ et viciis // myftice ad intellectū trāffūptis recolle // ctorii finis. Anno nre falut $(\mathrm{M}) \operatorname{cccclxxx} / /$ viii.kalendas vero februarii.xviii. 


\section{Folha 94v: branca}

Folha 95: branca

Folha 96r (ass. o): Tabula generalis (atéf. 97r)

Folha 97v até 101r: Tabula Alphabetica

Folha 101r, $2^{a}$ col.: (42 linhas) // expliciunt due tabule fiue duo dire // ctoria otento $\pi$ hui9 libelli. p qrū primā // vnicuiq3 caplo pōt attribui debit ${ }^{9}$ ver $^{9} / /$ et ordinat ${ }^{9}$ titulus cū numero fuo. Per // fcdam vo alphabetice ordinatā cito in- // uenifif pulcra T plurima exēpla q fpar // fim in finglis capitul' $\mathrm{T}$ in eorundē expo // fitionibus fiue moralifatōibo Jtinenf.

Folha 101v: branca

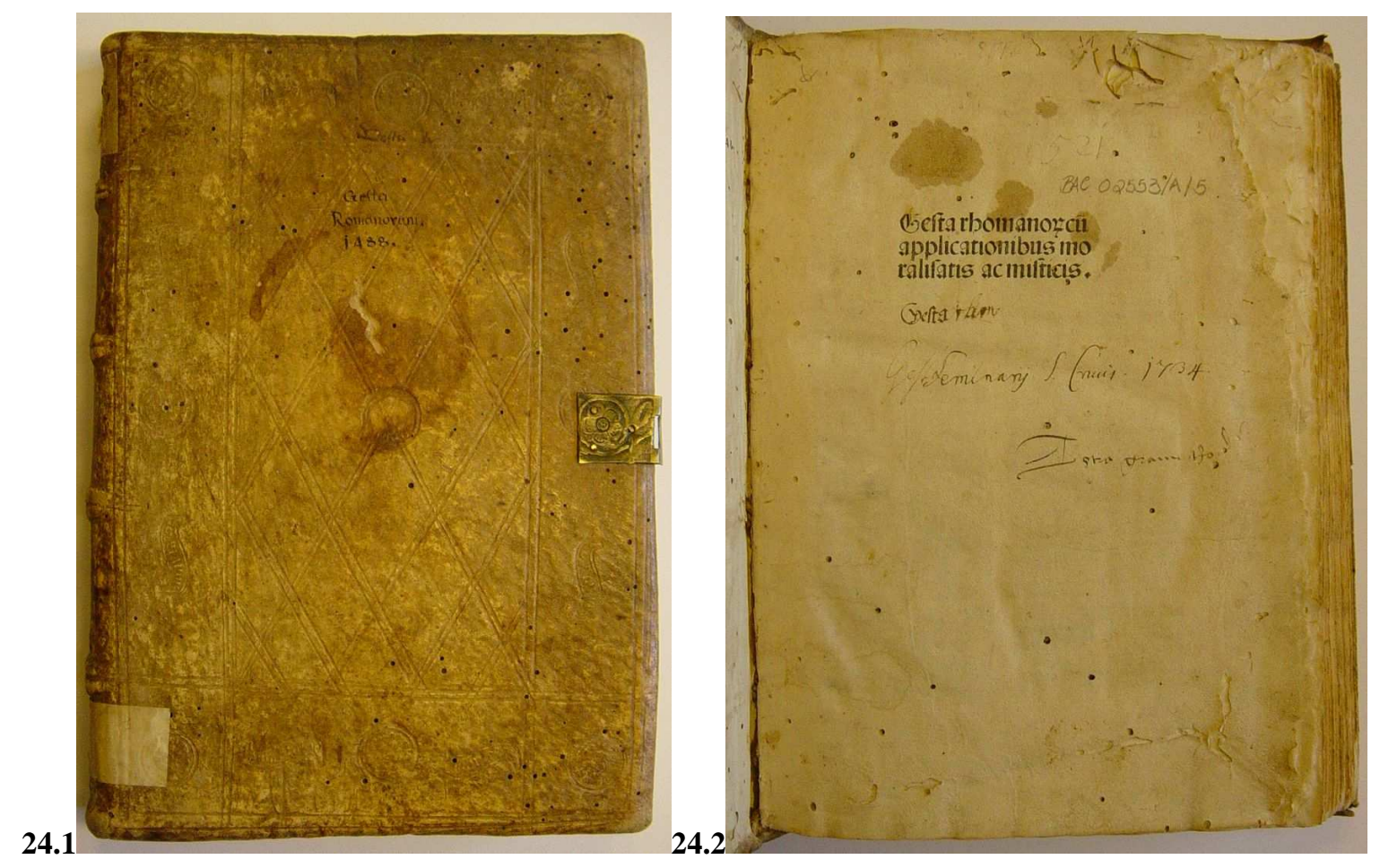

Fig. 24.1 e 24.2 - detalhe da encadernação e da folha de abertura com título (f. 1r).

Encadernação alemã, do século XV ou XVI, com pastas de madeira revestidas com couro de porco ao alúmen, decoração com gravação a seco, fechos de metal parcialmente conservados, lombada com quatro nervos duplos salientes e etiquetas de papel manuscritas aplicadas no pé e cabeça da lombada. Exemplar com anotações apenas na primeira folha.

Johannes Grüninger (1480-ca.1531) foi um dos principais impressores de Estrasburgo e em algumas edições seu nome aparece como Reinhard. Sua primeira obra, a Historia scholastica de Pertus Comestor, foi impressa em parceria com Heinrich de Ingweiler, mas passou a trabalhar sozinho a partir do ano seguinte. No século XV Grüninger editou mais de cento e cinquenta obras e continuou ativo até 1531. 
Esta obra foi muito publicada do final do século XV (25 edições) até o século XVII; sua popularidade provavelmente se deu por ser um apanhado de histórias de caráter moral. $\mathrm{O}$ vinho aparece em referência ao início da viticultura (De inventione vinearum), aos benefícios de seu uso moderado, aos méritos do vinho e à virtude da temperança. 
25.

SALIS, Baptista de (Trovamala) (séc. XV)

\section{Summa casuum conscientiae. $=$ Summa rosella .}

Nuremberg : Anton Koberger, 14 de abril de 1488.

[1], CCLXVII, [8]f. ; $32 \mathrm{~cm}$ (in fol.)

Texto em latim. Acresc.: Sixtu IV: Bulla "Etsi dominici gregis" 30 dez. 1479. Rubricae iuris civilis et canonici. O autor também é conhecido como Baptista Trovamala.

Assinatura: $a^{8} b-f^{8} f^{8} h-v v^{6} x x-y y^{8}$

2 colunas; 60-61 linhas, tít. corr.; caracteres góticos; espaços para iniciais; letrasguia.

Filigranas: igreja e cabeça de boi.

Procedência: Joannis Caspari Maisnigery, M. Andreæ Rudolphi (Ex-libris manuscritos).

Exemplar com encadernação em couro de porco sobre pastas de madeira.

Assunto: Religião

Interesse vinário: Embriaguez

Referências: Arnoult 1292; BMC II 432; Borm 332; BSB-Ink T-475; CIBN B-66; CIH 487; Coll(U) 238; Ernst(Hildesheim) I,I 352, 353; Finger 130 a 134; Girard 394; Goff S46; Günt(L) 2060; Hain 14181*; Hillard 272; Hubay(Augsburg) 273; Hubay(Eichstätt) 127; IBE 705; IBP 782; IDL 626; IGI 1204; Madsen 527, 528; Oates 1013; Ohly-Sack 375, 376; Pad-Ink 86, 87; Péligry 694; Pell Ms 11211; Polain(B) 3837; Proctor 2063; Sack(Freiburg) 442; Sajó-Soltész 487; Schmitt I 1730; Sheppard 1508, 1509; Simon BBI 120; Torchet 830; Voull(B) 1730; Voull(Trier) 1078; Walsh 712; Zehnacker 2047.

Banco de dados: GW 03322; ISTC is00046000.

Exemplares conhecidos: 49 (6 imp.).

Fac-símile eletrônico disponível em Verteilte digitale Inkunabelbibliothek <http://inkunabeln.ub.uni-koeln.de/vdib-info/kleioc/is00046000> e em Biblioteca de Andalucía:

<http://www.juntadeandalucia.es/cultura/bibliotecavirtualandalucia/catalogo_imagenes/gru po.cmd?path=10030>. 
Outro incunábulo na BVR: $n^{\circ} 47$

00004

Folha 1r: branca

Folha 1v: [ ${ }^{3}$ ]Nimuero cū grandes materias ingenia parua // nō ferant ad tanti negocii pōdus fubeundū:nō nubi aninium tam cupidum: q3 nec ido // etc.

Folha 2 (ass. a, f. I): Incipit Summa cafuū vtiliflima p veneran- // dum patrem frēm Baptiftaz de Salis ordinis mi // no $\pi$ de obferuantia. Prouincie Janue:nouit cō- // pilata que Baptiftiana nuncupat. // etc.

Folha 268 (n. CCLXVII), $2^{a}$ col: (51 linhas) // Quod quidē opus ad laudē ipkus Iefu: totiufq3 // trinitatis:ac virginis gloriofe: 7 oīm fanctorum fa // uēte pfidio. Pcipue beatorū Tiburcii 7 valeriani // marty $\pi$ : q $\pi$ folēnitas hodie agit a xpicolis: necnō // et fimpliciū confefforū vtilitatē vt plogo pmittite // expletū eft in Nuremberg impiali ciuitate partis germanie: p Anthoniū Koberger inibi cōciuem. // Anno currente. M.cccclxxxviii. // Sit laus deo.

Folha 268v, $2^{a}$ col. : (36 linhas) // Nulli g тc. Datū rome apud fan. Pet anno in- // carnatōnis dñice. $\mathrm{M}^{\circ} \cdot \operatorname{cccc}^{\circ} \cdot 1 \mathrm{xxix}$. die tercio $\mathrm{kl}^{\prime}$. Ianuarii. Pontificatus nri anno nono. // Barbariē refugis:ftrumofa cacumina lector // etc.

Folha 269 a 276: Rubrice indice

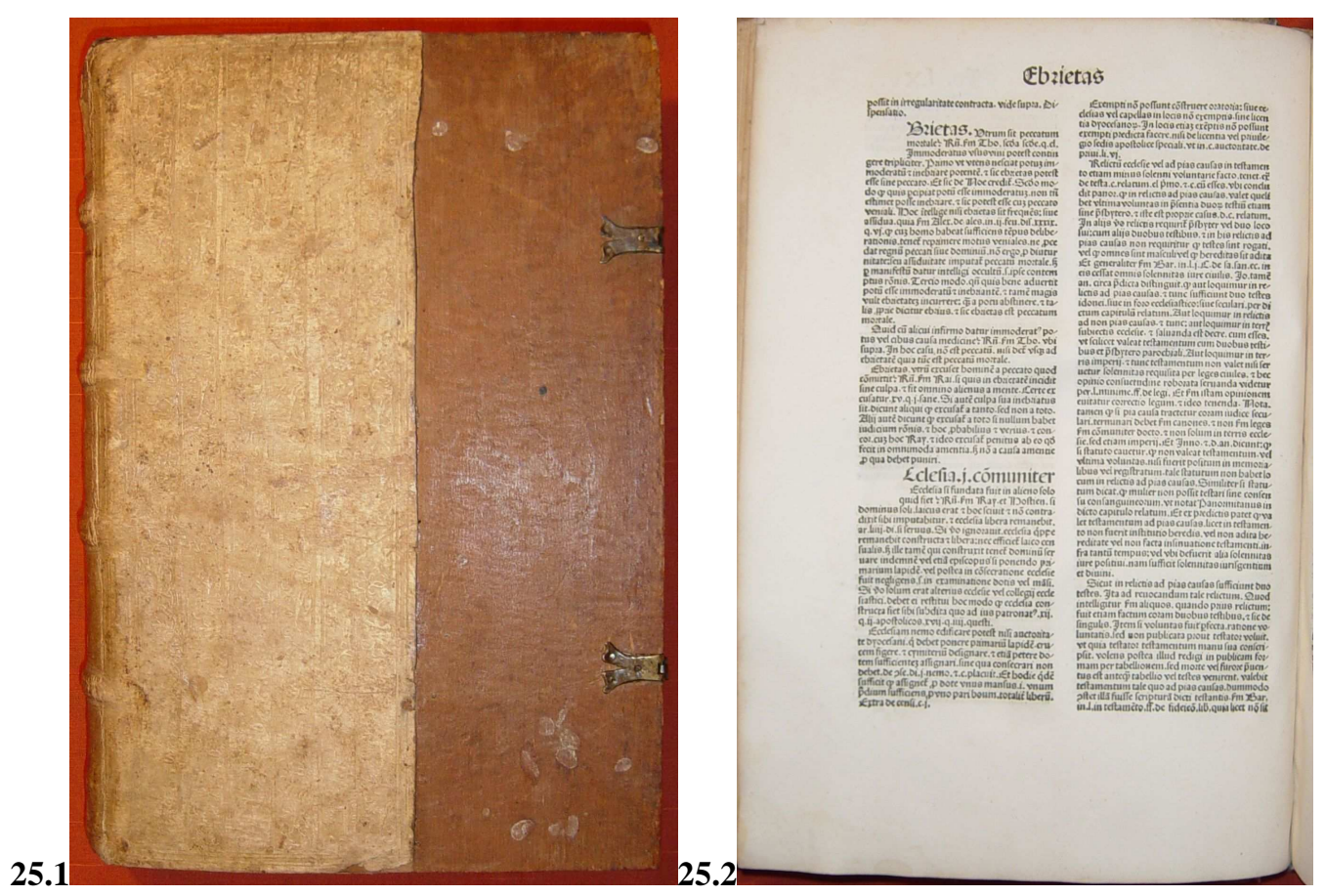

Fig. 245.1 e 25.2 - detalhe da encadernação e da página sobre a embriaguez (Ebrietas). 
Exemplar com encadernação original, provavelmente do século XV, pastas de madeira com lombada em couro de porco ao alúmen decorado a seco, um dos fechos perdidos, com algumas anotações e textos sublinhados e ex-libris manuscrito na primeira folha.

Este é mais um exemplo da maestria do impressor alemão Anton Kromberg fazendo par perfeito com a encadernação da época.

Sabe-se pouco sobre Baptista de Salis, apenas que foi franciscano, também conhecido como Baptista Trovamala, e notabilizou-se nas últimas décadas do século XV, quando sua obra foi impressa nove vezes, morrendo provavelmente em 1496. Summa casuum conscientae faz um levantamento de todos os tipos de pecados e de casos de consciência, e discute longamente a questão do vinho sob o título Ebrietas apresentando suas regras para determinar quem está ou não "pecaminosamente" ébrio. 


\section{8-1489}

26.

\section{ALEXANDER APHRODISAEUS}

Problemata (Trad. Georgius Valla) Acresc. Aristoteles: Problemata (Trad. Theodorus Gaza. Ed. Nicolaus Gupalatinus). Plutarchus: Problemata (Trad. Johannes Petrus Lucensis. Ed. Johannes Calphurnius).

Veneza : Antonious de Strata, de Cremona, 1488-1489.

[88]f. ; $29,3 \mathrm{~cm}$ (in fol)

O texto foi publicado em três partes com as seguintes datas: 24 de novembro de 1488; 18 de dezembro de 1488; 3 de janeiro de 1488/89.

Texto em latim.

Assinatura: $a^{8} b-n^{6} o^{8}$

Texto e comentário, 55-57 linhas; caracteres romanos; registro.

Filigranas: balança

Encadernação pergaminho do século XVII.

Assunto: Filosofia

Interesse vinário: Embriaguez

Referências: BMC V 295; BSB-Ink A-237; CIBN A-205; Coll(S) 39; Goff A387; Günt(L) 3736; HC(Add) 658*; IBP 188; IGI 284; Klebs 44.1; Louda 45; Oates 1834; Pell 439; Proctor 4594; Riedl 20; Sack(Freiburg) 103; Sheppard 3712, 3713; Voull(B) 3917; Walsh 1850 .

Banco de dados: GW 00860; ISTC ia00387000.

Exemplares conhecidos: 88 (3 imp.)

04874

Folha 1r: branca

Folha 1v: VICTOR pifanus Ludouico mucenigo: præcellenti in eloquentia uiro.S.P.D. // [ $\mathrm{s}^{5}$ ]Ingularis doctrina: facundia minime uulgaris: îfignifq3 tua prudenta Ludouice // etc.

Folha $2 r$ (ass. aii): Georgius Valla placentinus iohāni marliano mathematico \& in tota philofophia medici- // naq3 præftantiffimo falutem plurimam dicit. // [ a ${ }^{7}$ ]Lexandri aphrodifei philofophi:ac medici præftantiflimi problemata:hor // etc. 
Folha $3 r$ (ass. aiii): ALEXANDRI APHRODISEI PROBLEMATA: PER GEORGIVM VALLAM // PLACENTINVM IN LATINVM TRANSLATA. // [ $\mathrm{p}^{7}$ ]Roplematum quædam per fe funt fidem faciētia: \& cognita omnis ambigui // etc.

Folha 11 (ass. b): cibatum educere \& perinde aluos exiccari? nempe quod multa cibi repletio non eft in mul // etc.

Folha 32r: ... // Impreffum Venetiis per magiftrum Antonium de ftrata cremonenfē. Anno domini. M.cccc. // lxxxviii.octavo caleñ.decembris. Laus deo.

Folha $74 v:$... // Expliciūt Ariftotelis problemata. Venetiis īpreffa per Antoniū cremonēfem de ftrata. Quæ // Theodorus gaze Teftalonicēfis olī e greco in latinū cōuertit. Eaq3 nup ultima emēdatio // ne emēdauit. A.M.cccclxxxviii.xv.klen.Ianuarii.Fœliciter. Laus deo.

Folha 88r: Expliciūt problemata Alexandri aphrodifei:e græco in latinū traducta p Georgiū Valla. Et // Ariftotelis problemata Theodoro îterpte. Et plutarchi problemata: fimul feriatī. qemēda // tiflima: exceptis iftæ Plutarchi tribus uel ad fūmum quatuor locis ubi græcū exēplar man // cū erat:tu cū melius habueris tua diligentia iungito. Vale. Impreflū Venetiis per Antoni // um de ftrata cremonenfem. Anno falutis nræ. M.cccclxxxviii.die Sabbati iii.no.ianuarii. // Regiftrū. // a b c d e f g h i k 1 m n o Oēs fūt terni:exceptis a o qui fūt quaterni.

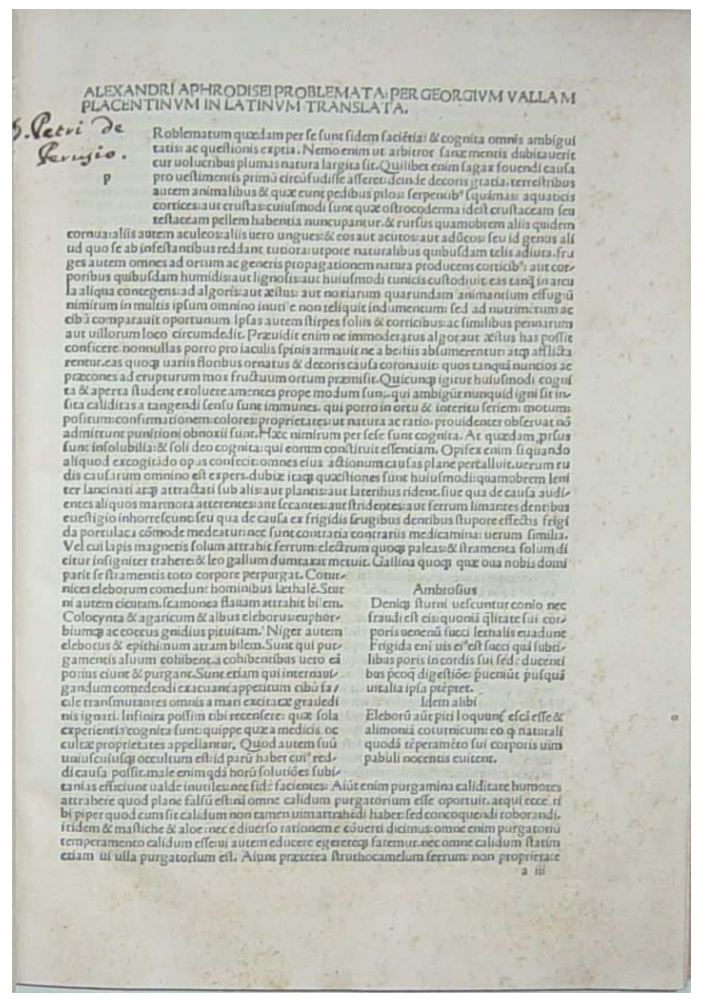

Fig. 26 - Página de abertura do texto de Aphrodisaeus (f. 3r). 
Encadernação em pergaminho do século XVII, com etiqueta de couro na lombada. Papel em bom estado, com poucas anotações, apenas com duas folhas com margens enxertadas.

O livro é composto de três obras distintas com o mesmo título Problemata. O segundo texto é uma coleção de dissertações científicas em forma de pergunta e resposta atríbuidas a Aristóteles; trata de temas variados como matemática, medicina, botânica, oceanografia, entre outros, incluindo o vinho, que justifica sua presença na coleção. 


\section{9}

27.

PEROTTUS, Nicolas (1430-1480)

Cornucopiae linguae latinae. = Cornucopia sive commentariorum linguae ad illustrissimum principen federicum urbini ducem.

Veneza : Paganinus de Paganinis, 14 de maio de 1489.

Edição príncipe.

[18], 355f. ; 30,3 cm. (in fol.)

Texto em latim, edição de Pyrrhus Perottus e Ludovicus Odaxius.

Texto com glosas impressas; 59 linhas; caracteres romanos; impresso em preto e vermelho (f. 3); letras-guia.

Assinatura: $a^{8} b^{10} a-z^{8} \& J \pi^{8} A-R^{8} S-T^{6}$

Xilografias: iniciais.

Filigranas: balança e terço.

Encadernação em pleno couro posterior, com nervuras e etiqueta em couro. Guardas marmorizadas (perda parcial da guarda da frente). Exemplar com algumas anotações marginais e algumas paginas com textos sublinhados, carimbo na primeira folha.

Assunto: Enciclopédia, vinho.

Interesse vinário: Embriaguez, história do vinho.

Referências: BMC V 455; Brunet IV p.505; BSB-Ink P-215; CIBN P-111; CIH 2569; Girard 360; Goff P-288; Graesse V p.205; Hain 12697; Hubay(Augsburg) 1587; IBE 4424; IBP 4253; IGI 7419; Madsen 3090, T80; Mendes 989; Mittler-Kind 441; Pell Ms 9217 (9040); Polain(B) 3049; Proctor 5162; Sack(Freiburg) 2719; Sajó-Soltész 2569; Sallander 1885; Sheppard 4250; Voull(B) 4266; Zehnacker 1775.

Banco de dados: CCPB 000111659-2; GW M13093; ISTC ip00288000.

Exemplares conhecidos: 89 (5 imp.).

02954

Folha 1r: IOANNIS FRANCISCI PHILOMVSI PISA VRENSIS TETRASTI // CHON IN CORNVCOPIAE PEROTTAEI LAVDEM. // Varronis: Nigidiq3 olim monumenta latinam 
// Ditarunt linguam Romuleofq3 patres // Pro quibus ammiflis Perotti copia raptas. // Omnifero e cornu plena refendit opes.

Folha 1v: branca

Folha 2 até 16 indices.

Folha 17r: branca

Folha 17v: Lodouicos Odaxius Patauinus Illuftriflimo // principi Guido Vrbini duci falutem. // [ ${ }^{5}$ ]Tolemæus Philadelphus: qui a rerum fcriptoribus tantopere celebratur // etc. Folha 17r: (15 linhas) // rum amantiflimo acceptum referent. V A L E

Folha 17v: branca

Folha 18 r (ass. a): PYRRHI PEROTTI IN CORNVCOPIAE: SIVE COMMENTARIOS // LINGVAE LATINAE AD ILLVSTREM PRINCIPEM FEDERICVM // DVCEM ET ECCLESIASTICI EXERCITVS IMPERATOREM INVI // CTISSIMVM. // PROHOEMIVM. // (M xil.)ORIENSolim. P. Maro poeta optimus maximus librum æneidos:quē // etc.

Folha 20r (ass. a3, f. 3): NICOLAI PEROTTI CORNVCOPIAE: SIVE COMMENTARIO // RVM LINGVAE LATINAE AD ILLVSTRISSI. PRINCI. FEDERI // CVM VRBINI DVCEM: ET ECCLESIATICI EXERCITVS IMPE // RATOREM INVICTISSIMVM. LIBER PRIMVS. // DE AMPHITEATRO EPIGRAMMA PRIMVS // (b ${ }^{13}$ )ARBARA PYRAMIDVM. Blanditur Domitiano // etc.

Folha 372v (f. 354): 33 linhas // ftratam: locupletatamq3 cognofcant. V A L E // Nicolai Peroti Eruditiflimi uiri Cornucopiæ feu comē // tariorum linguæ latinæ. Impreffum Venetiis per Magi- //ftrum Paganinum de paganinis brixienfem Anno do // mini M cccc.lxxxviiii. pridie idus maii. // FINIS.

Folha $373 r(f .355)$ : Registro

Folha 373v: branca

O volume deveria ter uma última folha branca, de acordo com as referências, mas a folha deste exemplar não parece original. Encadernação em pleno couro do século XVIII, com cortes pintados, lombada com nervuras e etiqueta em couro. Guardas marmorizadas (perda da guarda volante da frente). Exemplar com algumas anotações marginais, páginas com textos sublinhados e carimbo na primeira folha. 


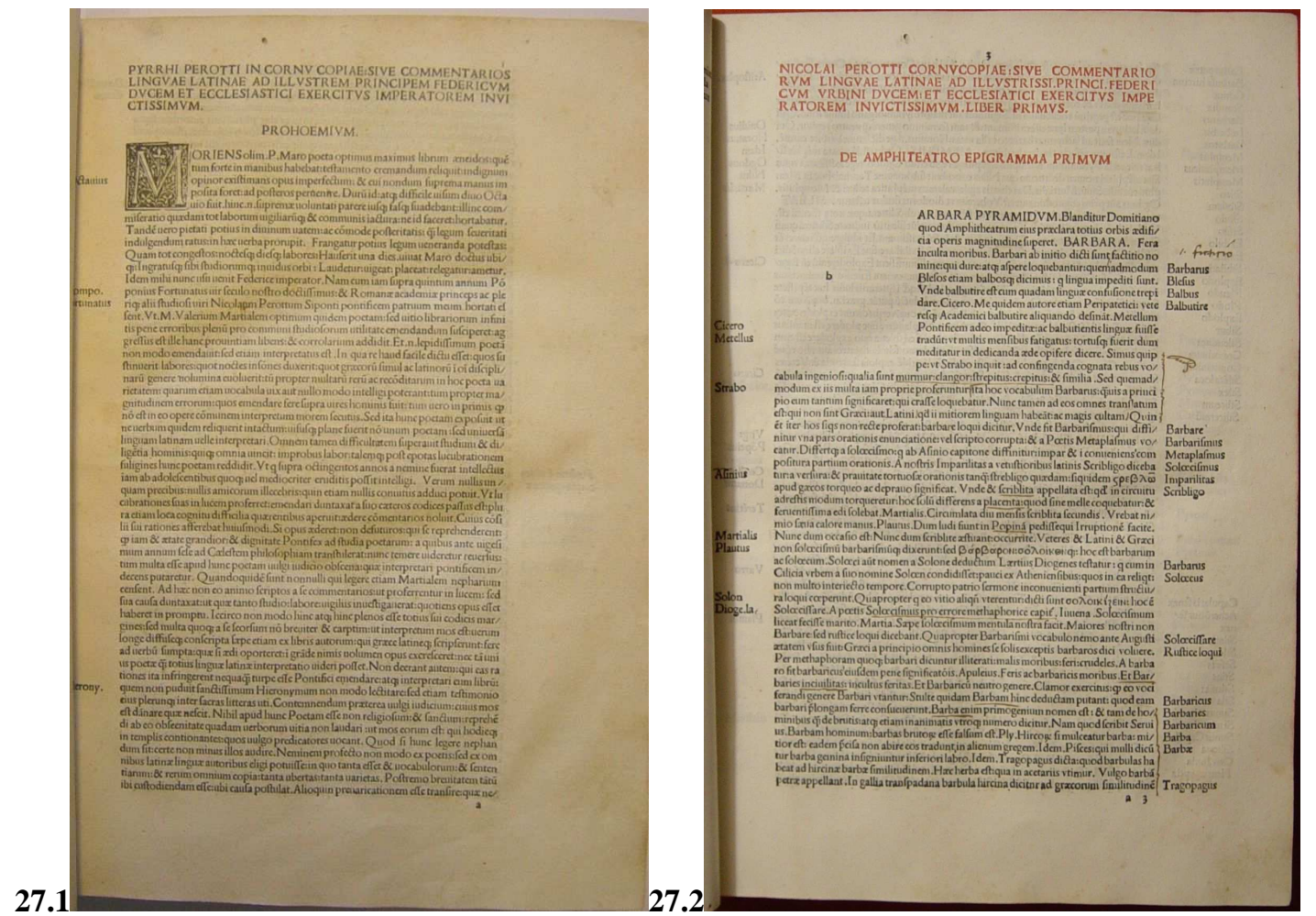

Fig. 25.1 e 27.2 - Página de apertura do prefácio (f. 18r) e página inicial do texto de Perottus (f. 20r).

Com relação à tipografia esta é a primeira obra da BVR com a presença de iniciais xilografadas impressas juntamente com o texto, utilização de duas cores na impressão (somente uma folha) e glosas impressas nas margens do texto. Trata-se de belo exemplo da evolução da nova arte da tipografia.

Perottus foi prelado e filólogo italiano, professor, arcebispo, chegando a governador. A importância desta sua obra está na presença de comentários enciclopédicos onde o vinho, a vinha e a embriaguez aparecem em diversas ocasiões; a passagem de maior interesse está no Epigramma XLVII que discorre sobre as diversas maneiras e razões de se beber. 


\section{0}

28.

CRESCENTIIS, Petrus de (ca.1230 - 1320)

Ruralia commoda = Il libro dell'agricoltura.

Vicenza : Leonardus Achates de Basilea, 17 de fevereiro de 1490.

[145]f. ; $30 \mathrm{~cm}$ (in fol.)

Texto em italiano.

Assinatura: $a^{7} b-r^{8} s^{6} A^{4}$

2 colunas; 52 linhas; caracteres romanos; il. xilogravuras (somente uma)

Filigranas: balança

Procedência: D. Gio. Battista Giuliani (ex-libris manuscrito)

Encadernação antiga em pergaminho.

Assunto: Agricultura.

Interesse vinário: Vinicultura, viticultura.

Referências: Arnoult 496; BInG p.531-2; BMC VII 1033; Brunet II p.418; BSB-Ink C-700; Goff C974; Graesse II p.299; HC(+Add) 5838; Henssler p.209; IBE 1957; IBP 1809; IGI 3267; Klebs 311.2; Parguez 364; Pell Ms 9332 (9155); Proctor 7128; Sander 2234; Sheppard 5894; Voull(B) 4583; Walsh 3486.

Banco de dados: GW 07827: ISTC ic00974000.

Exemplares conhecidos: 58 (4 imp., 2 frag.).

Outros incunábulos na BVR: ${ }^{\circ} 1$ e $\mathrm{n}^{\circ} 21$

03725

Folha 1r (ass. $\mathrm{a}_{\mathrm{i}}$ ): xilogravura, $1^{\mathrm{a}}$ coluna, INCOMINCIA IL LIBRO DELLA A- // GRICVLTURA DI PIERO CRESCI- // ENTIO CITTADINO DI BOLOGNA // AD HONORE DIDIO ET DEL SE- // RENISSIMO RE CARLOS. // ( a 5)Llo exciellentiflimo pricipe // meffer Carlos fecōndo per- // etc.

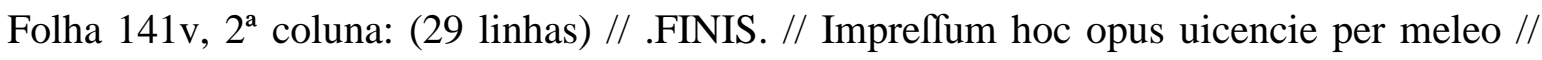
nardum de bafilea die .xvii.mēfis Februarii // anno.D.Mcccclxxxx. // a.b.c.d.e.f.g.h.i.k.l.m. n.o.p.q.r.f. // tutti fono quaterni excepto .f. che terno. 
Folha 142r (ass. A): TAVOLA DEL LIBRO DELLE VIL- // lerecie utilita di piero crefciētii cittadino di // bologna adhonore del ferēiflimo re carlo // etc.

Tabela segue atéf.145r.

Folha 145v: branca

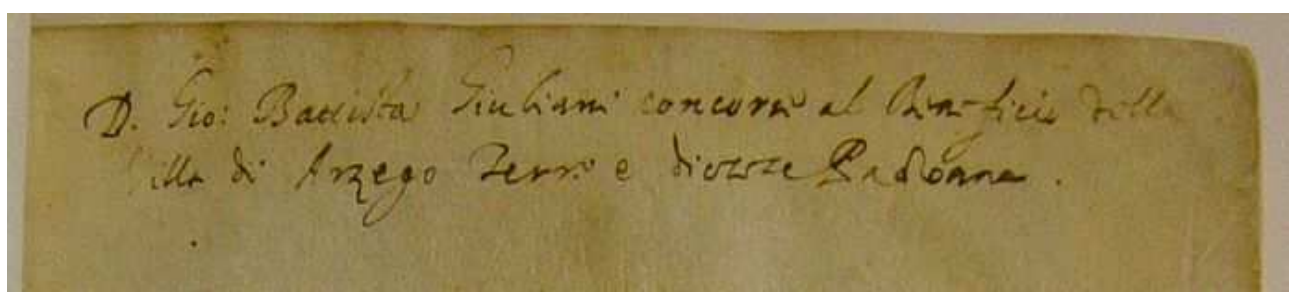

Fig. 26.1 - Detalhe do ex-libris manuscrito, parte superior da folha de guarda.

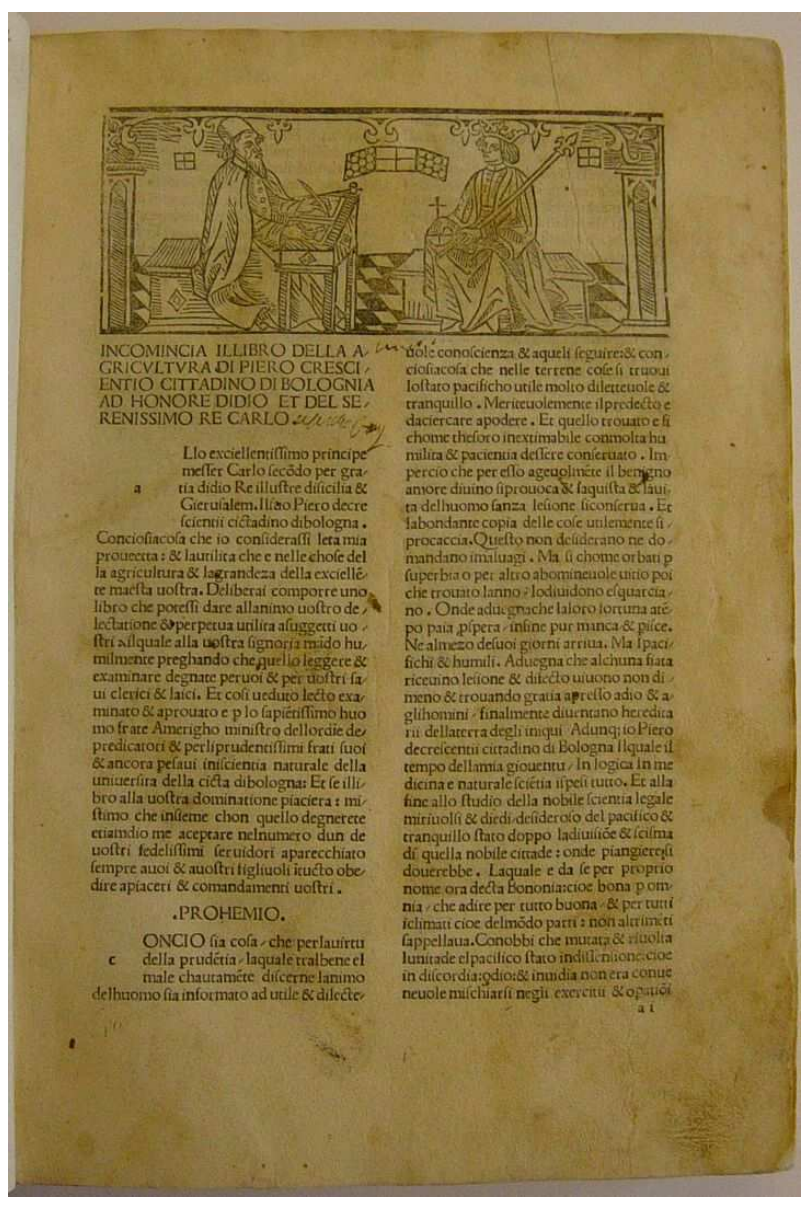

Fig. 279.2 - Página de abertura com xilogravura (f. 1r).

Encadernação flexível em pergaminho, provavelmente do século XVII, com lombada manuscrita. 
29.

LACTANTIUS, Lucius Coelius Firmicinis (ca. 240 - 320)

Opera.

Veneza : Theodorus de Ragazonibus, 21 de abril de 1390 [i.e. 1490].

[148]f. ; $31 \mathrm{~cm}$ (in fol.)

Texto em latim. Edição de Johannes Andreas de Buxis. Acres.: S. Venantius Honorius Clementianus Fortunatus: De Resurrectione Christi carmen

45 linhas, tít. corr.; caracteres romanos e gregos, espaço para capitulares; letrasguia; registro.

Asinatura: $a-f^{8} g^{6} h-k^{8} 1^{6} m-o^{8} p^{14} q-r^{8} s^{6} r^{4}$

Filigranas: cabeça de boi, balança e sino.

Encadernação da época.

Assunto: Literatura

Interesse vinário: História do vinho.

Referências: Arnoult 945; BMC V 477; BSB-Ink L-9; CIBN L-10; Coll(U) 93; Fernillot 362; Goff L10; Günt(L) 3580; HC 9815; IBE 3419; IBP 3341; IDL 2870; IGI 5627; Madsen 2433; Parguez 642; Péligry 497; Pell Ms 6993 (6945); Polain(B) 4510; Proctor 5262; Sajó-Soltész 2020; Sheppard 4340; Voull(B) 4317; Walsh 2410, 2411; Zehnacker 1392.

Banco de dados: M16563; ISTC i100010000

Exemplares conhecidos: 161 (13 imp.)

00021

Folha 1: branca (com anotações / assinaturas)

Folha $2 r$ (ass. $a_{i i}$ ): Lactantii Firmiani de diuinis inftitutionibus aduerfus. Gētes. Rubricæ primi libri in // cipiunt. // $\left(\mathrm{q}^{2}\right)$ Vanta fit \& fuerit femper cognitio ueritatis. Et q nec fine religione fapientia: nec // etc.

Indice segue até $f .8 \mathrm{v}$

Folha 9r: branca

Folha 9v: Ioannis Andreæ epifcopi Alerienfis ad Paulum fecundo Venetum pontificem ma// ximum epiftola. // etc. 
Folha 10 (ass. b): PROOEMIVM // L.COELII LACTANTII FIRMIANI DIVINAR VM INSTITVTIONVM // ADVERSVS GENTES DE FALSA RELIGIONE. LI //BRI PRIMI PRAEFATIO ED IMPERATO // REM CONSTANTINVM. // etc.

Folha 148v: (19 linhas) // Lactantii Firmiani in Ephytomon tractus finit. // Impreffum Venetiis per magift $\pi$ Theodo $\pi$ de Ragazonibus de Afula. Anno incarna // tionis domini. M.CCC.(sic) LXXXX. Vigefimo primo menfis Aprilis. // Regiftrum huiuh operis fic habet. // segue registro... // t// hos aflectus // Dixi de his
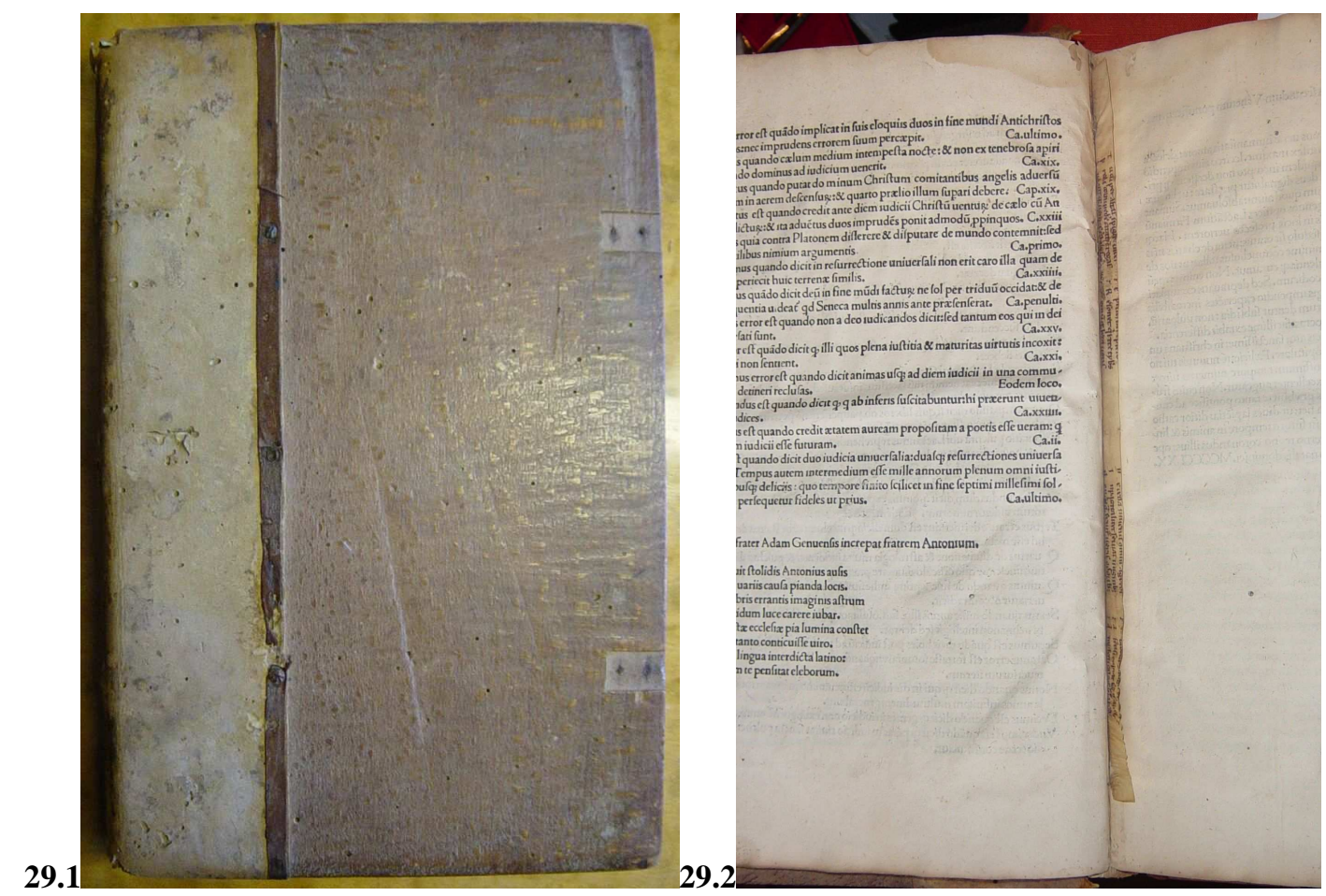

Fig. 2928.1 e 29.2 - Encadernação e detalhe do reforço interno em pergaminho.

Encadernação do século XV ou inicio do XVI, com capas de madeira revestidas de couro somente na lombada, fechos perdidos. No detalhe (figura 30.2) pode-se observar a tira de pergaminho manuscrito reaproveitado para reforçar a estrutura da encadernação.

Exemplar com algumas manchas, sem anotações; apenas assinaturas e inscrições nas primeiras folhas.

Lucius Coelius Firmicinis Lactantius nasceu no norte da África e converteu-se ao Cristianismo, em cuja crença produziu sua obra, chegando a ser chamado de "Cícero cristão". Neste livro o tema vinário aparece fortuitamente, quando fala que Noé inventou o vinho, ou quando comenta o direito que em Roma tinha o marido de proibir a esposa de beber vinho. 


\section{[ca. 1490]}

30.

TRACTATUS EXCELLENTISSIMUS QUI DE REGIME SANITATIS.

[Lyon], [ca.1490].

[80]f. ; $19,0 \mathrm{~cm}\left(\right.$ in $\left.4^{\circ}\right)$

Texto em latim. Atribuido a Arnaldo de Villanova. Corretores: Doctores Montispesulani regentes.

Assinatura: $\mathrm{a}-\mathrm{k}^{8}$

33 linhas; caracteres góticos; espaço para iniciais.

Procedência: Ex-libris não identificado (brazão com leão); Antoine Desirré (?), 1723 (anotação manuscrita).

Encadernação em pergaminho em caixa de conservação. Encadernado junto com $L a$ vertu et propriete des eaux artificielles $\left(\mathrm{n}^{\circ} 51\right)$.

Assunto: Medicina

Interesse vinário: Vinho como remédio.

Referências: C 5059; CIBN R-41; Goff R68; IBE 4875; IBP 4686; IGI 8300; Klebs 830.7; Pell 1283; Zehnacker 1981.

Banco de dados: GW M37364; ISTC ir00072500

Exemplares conhecidos: 7 (2 imp.).

Outro incunábulo na BVR: $\mathrm{n}^{\circ} 72$

02705

Folha 1r: Regimen sanitatis

Folha 1v: branca

Folha $2 r$ (ass. $a_{i i}$ ): Incipt regimen fanitatis falernitanuz excellentiflimū p // cōfervatōne fanitatis ton9 humani generis putiliffimū. nec // nō a magifto Arnaldo de villa noua cathelano oìm medico // rū viuentiū gemma vtiliter ac fcd'm oìm antiquo medico // doctrinaz veraciter expofitū nouiter correctū ac emendarus // p egregiflimos ac medicine artis peritiflimos doctores mon // tifpeffulani regentes anno. M. CCCC. octuafimo. predicto loco actu moram trahentes. // [ $\mathrm{A}^{3}$ ]ngorus regi fdripfit fcola tota falerni. // etc.

Folha 80r: (24 linhas) // Hoc opus optatur qd flos medicine vocatur. // Tractatus excellentiflimus qui de regimine fa // nitatis nuncupatur. Finit feliciter. 


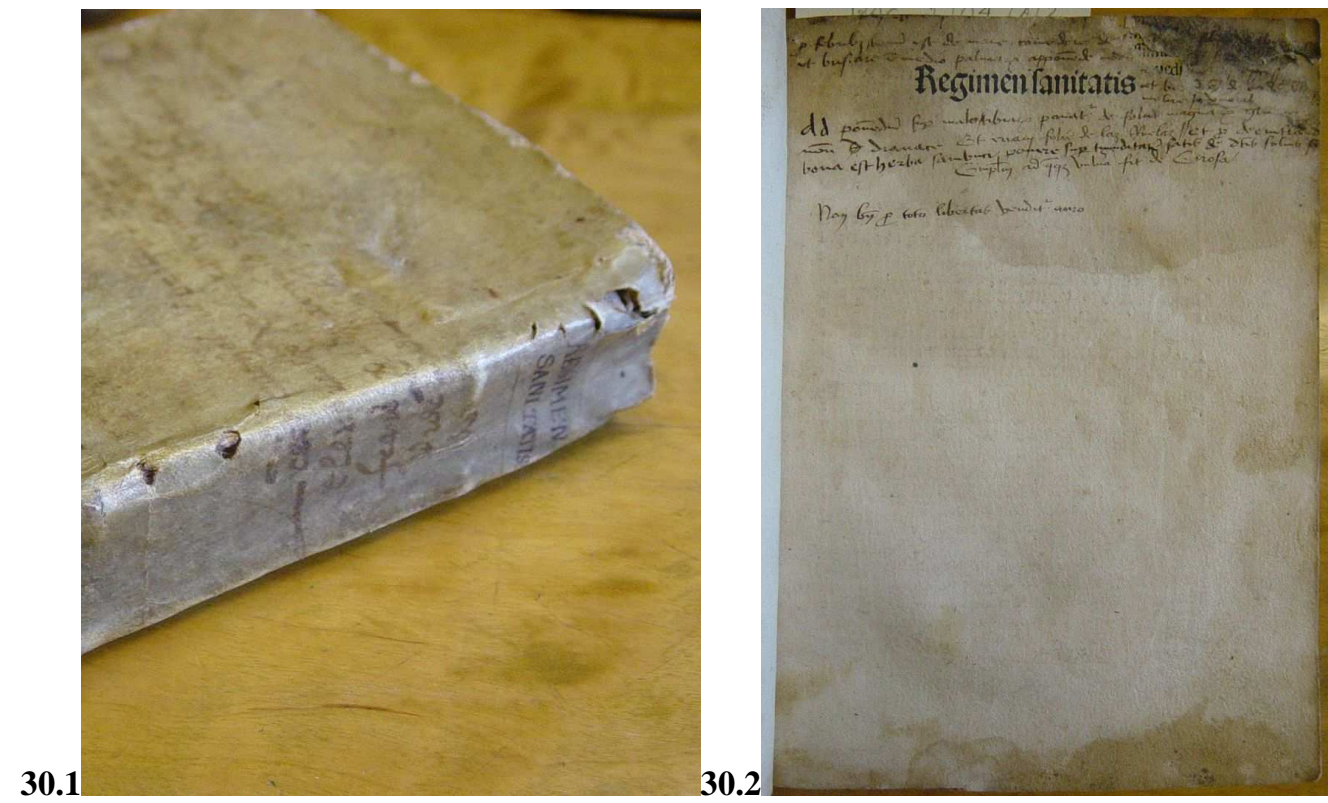

Fig. 30.1 - Detalhe do pergaminho manuscrito utilizado na encadernação.

Fig. 30.2 - Folha de apertura com título da obra e isncrições manuscritas.

Encadernação em pergaminho, reaproveitando pergaminho manuscrito; folha de abertura da obra possui diversas inscrições manuscritas e manchas; caixa de conservação. Encadernado junto com La vertu et propriete des eaux artificielles ( $\left.\mathrm{n}^{\circ} 51\right)$.

A Escola de Salermo, fundada por volta do ano 1000 na cidade italiana de mesmo nome, celebrizou-se pelos seus preceitos, que se tornaram normativos para as faculdades de medicina européias. Surgiram como aforismos, em versos latinos, que sofreram grande acréscimo nas sucessivas reedições e traduções.

O vinho é referência recorrente desses aforismos, sob o enfoque medicinal.

A autoria da versão original é desconhecida, embora até recentemente (Simon) ainda fosse atribuída erroneamente a Arnoldo de Villanova.
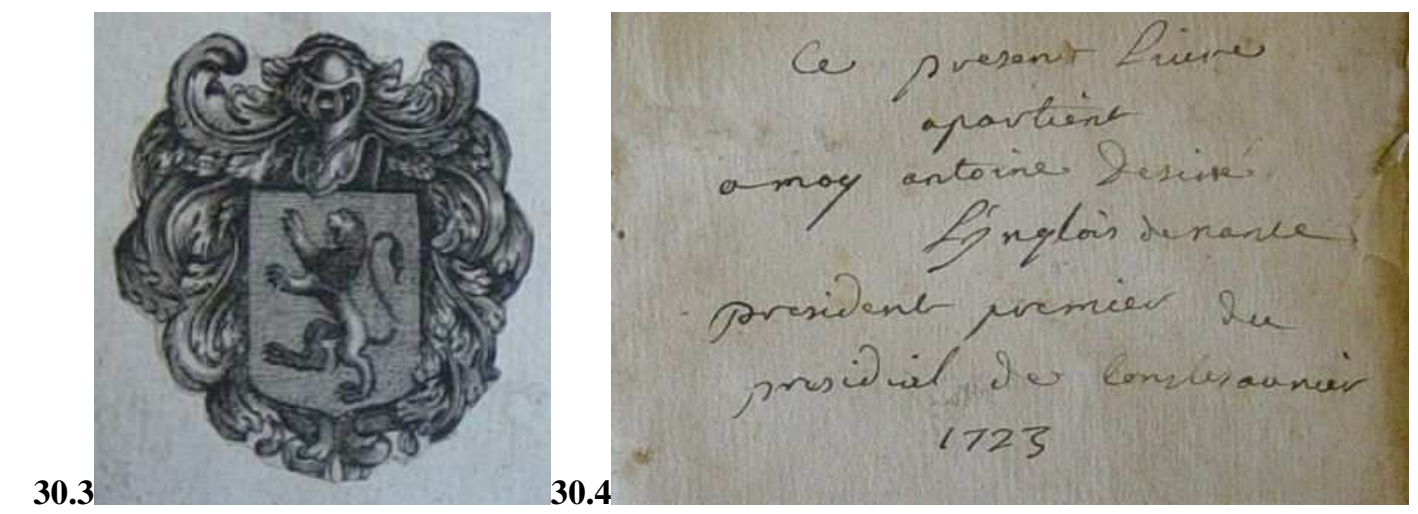

Fig. 30.3 - Ex-libris não identificado. Fig. 30.4 - Ex-libris manuscrito de 1723. 


\section{9-1491}

31.

MESUE, Johannes (777- 857 d.C.)

Opera medicinalia. Acresc: Abulcasis: Liber servitoris de praeparatione medicinarum simplicium (Trad. Abraham Tortuosiensis. Ed. Simon a Cordo). Franciscus Pedemontanus: Complementum. Mundinus: Expositio super canones universales. Nicolaus Salernitanus: Antidotarium, Quid pro quo, Synonyma. Christophorus de Honestis: Expositio super Antidotarium Mesue. Petrus de Abano: Additiones ad practicam. Saladinus de Asculo: Compendium aromatariorum.

Veneza : Peregrinus de Pasqualibus, Bononiensis, 1489-91.

46, 38, 244 (i.e. 240), 29f. ; 31,0 cm. (in fol.)

Publicado em três partes em: 21 de novembro de 1490; 2 de dezembro de 1489; 18 de julho de 1491. Paulus de Vareschis aparece como editor em nota do ISTC.

Texto em latim.

2 colunas, 34 linhas, caracteres góticos, impresso em preto e vermelho (titulos).

Assinatura, parte I: $a^{7} b^{6} c^{8} d^{10} e^{8} f^{6}$ aa-dd $d^{8} e^{6}$; parte II: A-D ${ }^{8} E^{10}$ F-G $G^{6} H-R^{8} S^{7} T$ $\mathrm{Y}^{8} \mathrm{Z}^{7^{*}} \mathrm{AA}-\mathrm{CC}^{8}$ DD-FF ${ }^{6} \mathrm{GG}^{8} \mathrm{HH}^{4} \mathrm{KK}^{6}$; Parte III: LL-MM ${ }^{8} \mathrm{NN}^{6} \mathrm{OO}^{8}$

Filigranas: balança, cabeça de boi, sino

Procedência: The Wellcome Library

Encadernação com lombada em pergaminho e papel estampado.

Assunto: Medicina

Interesse vinário: Vinho como remédio

Referências: BMC V 391; BSB-Ink M-347; Finger 68; Goff M-515; Hain 11110*; Hubay(Augsburg) 1415; Hubay(Eichstätt) 687; IBP 3714; IGI 6391; Klebs 680.13; Poynter 381; Sack(Freiburg) 2439; Sajó-Soltész 2264; Voull(B) 4082,5.

Banco de dados: GWM23017; im00515000.

Exemplares conhecidos: 41 (7 imp.) 
Folha 2 (ass. $a_{2}$, num. 2): Preclariflimi medici magiftri Dini // fup canōes fiue aggregatiōes Mefue $\partial$ // rectificatiōe medicīa $\pi$ fim. folu.expofitio // $\left(i^{6}\right)$ Nnomine // di mifericordis cni ${ }^{9}$ nu // etc. Comentario: $\left(\mathrm{i}^{5}\right)$ Nnomine dei mifericordis $\mathrm{\imath c}$. Medicina eft additō // etc.

Folha 46v (num. 47) $2^{a}$ col.: Expleta eft fectio fecunda vbi deefle et poffe vni // ufcuiufq medicinarum fimplicium et rectificatōe ae- // rum et tam de benedict| medicinis $q$ de foluentibus la // boriofle traatatum eft gloriofiflimi doctoris Mefue // ad laudem dei eterni qui fit benedictus. Amen.

Folha $47 r$ (ass. aa): Ioānnis mefue grabadin. qd eft aggre // gatio 7 antidotarium electuariorum $\rceil$ cō // fectionū: 7 aliarū medicinarū cōpofitarū. ( $\left.\int^{4}\right)$ Cripfimus // in libri explanationū nraru // etc.

Folha $84 v$ (num. 40 i.e. 38), $2^{a}$ col.: Explicit vtilis expolitio Chriftofori Georgii de hone // ftis Florentini fuper antidotario Mefue cum tractatu de aqua // ordei. Et de modo faciendi ptifanam $\mathrm{fm}$ cōmunem modum // practicantium diligentiflime emendata. Impreffa in Inclyta // ciuitate Ueneciis per Pelegrinum de Pafqualibus Bono // niens. Mcccclxxxx. Die .xi. klar decembris.

Folha 85 r (ass. A, num. 1): Summa fecunda huius grabadin incipit in qua di // ftinguuntur medicine appropriate egritudinibus fin- // gulorum membrorum. ( $\mathrm{s}^{11}$ )Anat Solus lāgōes // deus: 7 de fru- // etc.

Folha 126v (num. 42), $2^{a}$ col.: Iohānis Meūie Medici Singularis de Me // dicinis particulariū egritudinū Liber feliciter explicit.

Folha 127 (ass. F, num. 43): Petri apponi medici clariflimi in librum iohannis // mefue additio incipit.

Folha 138v (num. 54), $2^{a}$ col.: Petri apponi medici clariflimi in librum Iohan // ni Mefue (rasum quid) Addio Feliciter finit // Oratio ad memoriam impetrandam.

Folha 139r (ass. H, num. 55): Hic pfeqtur clariflimus doctor francifcus de pede // dontium complet $\mathrm{T}$ fecundam diuifiōes fuperius anota // tā in primo de appropraitis Diui Iohānis Mefue

Folha 219: faltando

Folha 252: faltando

Folha 296 (num. 222), $2^{a}$ col.: Hic complemento doctoris famofiflimi Franci- // fci Pedemontium in Diui Iohannis // Mefue Chrifto fauente finis felix // ftatuitur. Nunc confequen- // ter Antidotarium Nico // lai feliciter Inci- // pit inferius

Folha 297 (ass. EE, num. 223): Incipit Antidotarium Nicolai cum // Expofitionibus glofis clariflimi phyfici // magistri Platearii 
Folha 320v: (n. 248), $2^{a}$ col.: Antidotarium Nicolai cum expofi- // tionibus: glofis Famofiflimi medici // magiftri Platearij finit.

Não há ass. II, faltando folha 321.

Folha 327v (n. 291), $2^{a}$ col.: Explicit tractatus fynonimu impreffus Uenetiis. // per Peregrinum de pefqualibus Bononienfem // Ano domini M.C

CCC.lxxxix. die fecūdo decembris // Regnante inclyto principe Auguftino barbadico // Finis.

Folha 328: faltando

Folha 329r (ass. g i.e. LL, n. 1): Incipit liber Seruitoris liber .xxviij. Bulchafin // Benaberazerin: traflatus a Simone ianuenfi îterpre // te Abraam iodeo tortuofieufi.

Folha 357v (n. 30), $2^{a}$ col.: Hic finitur Mefue cum Mundino fuper canoni- // bus generalibus Chriftofaro (sic) Geordio fuper Antido // tario. Ac Petrus Apponenefis Et francifcus de pe // demōtium cum Nicolau comentato per platearium et // feruitore ac cum Saladino figillante dictum volumen // Que omnia vifa et corecta (sic) fuere per clariffimum phifi- // cum. D. Magiftrum Paulum de Uarefchis pata // uinum medicum in Alma vrbe Uenetiarum Fa // mofum Et impreffa Uenetijs per Pelegrinum de // pafqualibus de Bononia fub āno dñi. 1491. die. 18. // Mēfis Iulij Duce fereniflimo et īclito principe Au // guftino Barbadico. // LAUS DEO. Marca tipografica do impressor.

Folha 358r: Registro

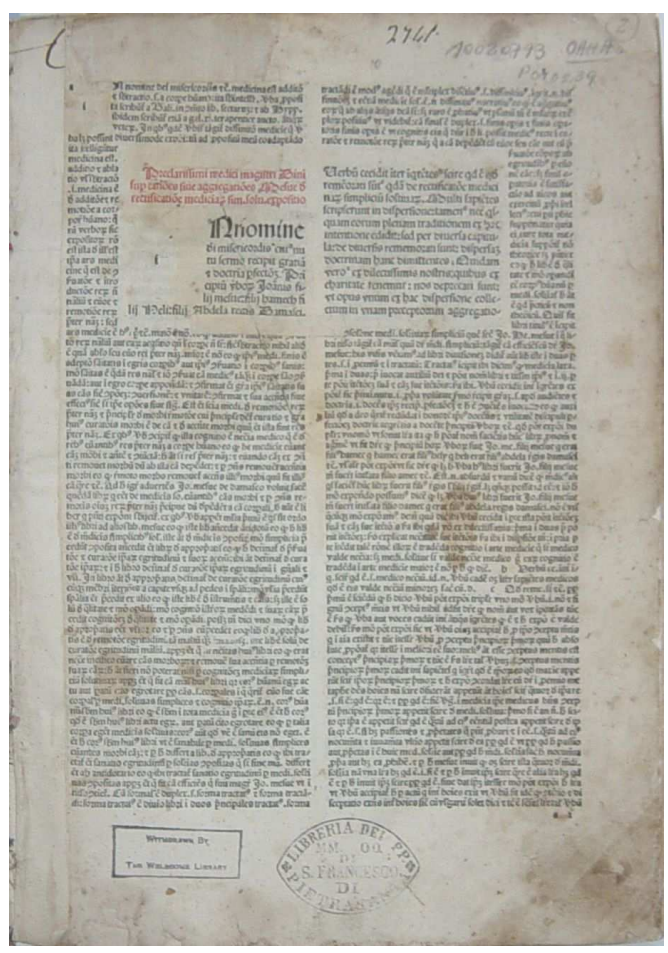

Fig. 29.1 - Página inicial da obra de Mesue. 


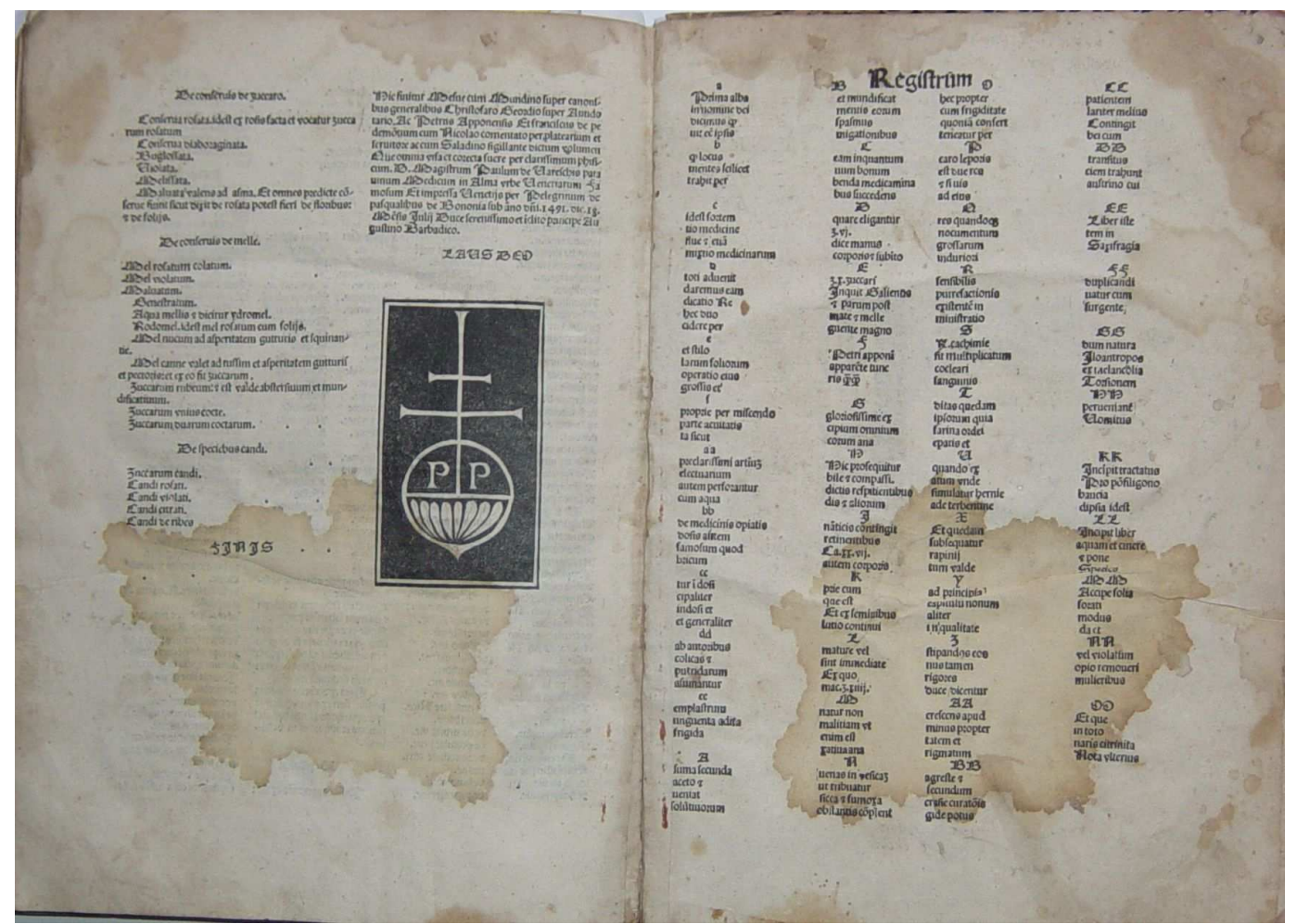

Fig. 31.2 - Final da obra, pode-se ver o colofão, marca do impressor e registro (f. 357v e f. 358r).

Encadernação com lombada em pergaminho, provavelmente do século XVIII e papel estampado (posterior) nas capas. Algumas folhas com anotações e manchas (principalmente as primeiras e últimas) mas em geral exemplar limpo e com boas margens. Há diversas falhas na numeração das folhas (repetição de números e saltos), e de acordo com Hain estão faltando quatro folhas: 219, 252, 321 e 328.

Yuhannah ibn Masawaih, conhecido na literarura italiana como Johannes Mesue, Mesue, o Velho ou Juan de Damasco, foi médico e cientísta árabe, de origem cristã que viveu entre 777 e 857. A obra de Mesue foi por muito tempo considerada uma das principais referências para a composição de medicamentos, sendo maioria elaborada a partir de plantas, e com a presença do vinho em inúmeras receitas como material medicinal.

Por ter sido publicada em três partes, em anos distintos, é dificil encontrar-se a obra completa. 


\section{1}

32.

MAYRONIS, Franciscus de (m. 1325)

\section{Sermones ab adventu cum quadragesimale.}

Veneza, Bernardinus Rizus, Novariensis, 20 de janeiro de 1491/92.

[1], 2-196, [19]f. ; $22 \mathrm{~cm}$ (in $4^{\circ}$ )

Edição príncipe.

Texto em latim.

2 colunas; 51-52 linhas; caracteres góticos [tipos: 10:120 G e 16:64 G]; letras-guia.

Assinatura: $a-z^{8} 7^{8} \supset^{4} A^{8} B^{7} C^{4}$

Filigranas: sino (chapéu)

Encadernação antiga em pergaminho restaurada, com caixa de conservação.

Assunto: Religião

Interesse vinário: Gastronomia, embriaguez.

Referências: BMC V 403; BN-RJ 79; Borm 1822; BSB-Ink F-249; CIH 2236; Finger 681; Girard 315; Goff M-92; Hain 10530*; Hubay(Augsburg) 1399; IBE 2501; IBP 3670; IGI 6313; Lefèvre 307; Madsen 1629; Mendes 853, 854; Neveu 249; Parguez 686; Péligry 529; Pell 4912; Polain(B) 4370; Proctor 4959; Sajó-Soltész 2236; Sack(Freiburg) 2410; Voull(B) 4135,8; Walsh 2185.

Banco de dados: CCPB 000109736-9; GW M22468; ISTC im00092000. Exemplares conhecidos: 153 (18 imp.)

Fac-símile eletrônico disponível na Biblioteca Digital da Universidade de Zaragoza: http://aneto.unizar.es/record/324

02890

Folha 1r: Quadragefimale doctoris illuminati // Francifci de Mayronis.

Folha 1v: branca

Folha $2 r$ (ass. $a_{2}$ ): Sermo Primus // Incipiunt fermones aurēi doctoris illu- // minan Francifci de mayronis ordinis mino- // rum ab aduentu cus quadragefimali vfq3 ad // 
quartam feriam poft pafcha. // Dominica prima aduentus. Sermio pri- // mus de epiftola 7 habet qnq3 Jfideratōes. // ( $\mathrm{f}^{7}$ )ratres fciē // tes quia hora eft iaz nos // etc.

Folha 196r, $2^{a}$ col.: (23 linhas) // Francifci mayronis aurei doctoris illumi- // nati fermones expliciunt. Venetijs diligentif // lime ac fummo ftudio imprefōi per Bernar- // dinuz de Nouaria. Anno ab incarnatoē dñi // Mcccclxxxxi.die vero.xx.mēfis Januarij. // Regiftrum. // a b c d e f g h i k l m n o pqr st v x y // z כ כ. Omnes hij funt quaterni; excepto כ// quod eft duernum. // Finis.

\section{Folha 196v: branca}

Folha 197: branca

Folha 198 r (ass. $A_{2}$ ): Tabula alphabetica fuper pmo volumine // fermonum de tpe elegantiflimi viri $\mathrm{T}$ pfeflo- // ris francifci de mayrone ordinis minorum // a dominica prima aduentus vfq3 ad feriā quar // taz in pafchalib ${ }^{9}$ bene quotata incipit feliciter. // etc.

Folha 215r, $2^{a}$ col.: (10 linhas) // Explicit tabula fuper primo volumine fer- // monum de tempore ab aduentu vfq3 ad fertaz // quartaz i pafchalibus doctoris illuminati ma // giftri Francifci de Mayrone de ordine mino // rum. Et funt fermones numero .92.

Folha 215v: branca

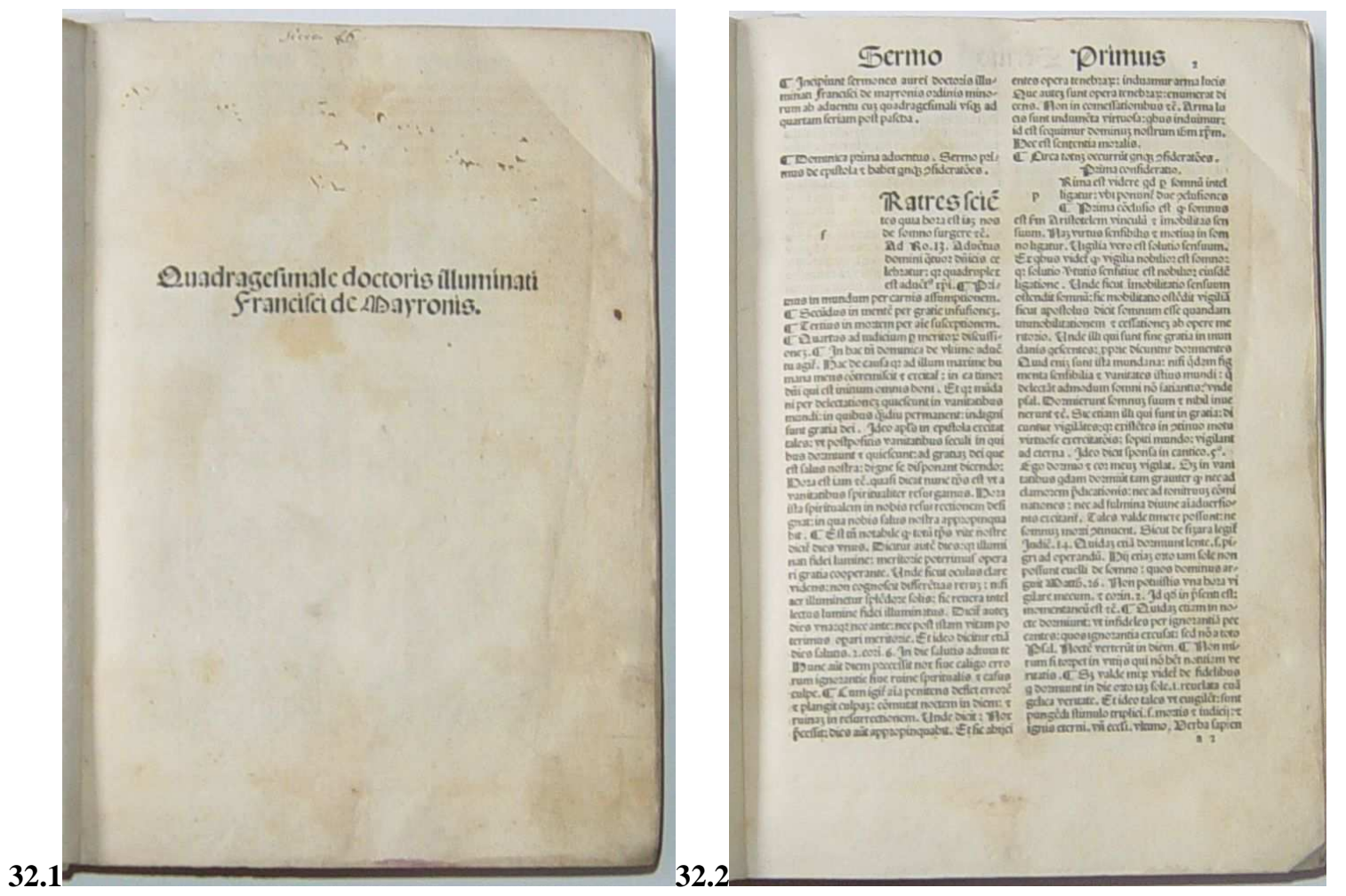

Fig. 30 - Página de abertura com título (f. 1r) e página de abertura dos sermões (f. 2r). 
Encadernação antiga em pergaminho com emenda na lombada, corte pintado de vermelho; apresenta sinais de fechos em couro perdidos; caixa de conservação. Algumas folhas com anotações manuscritas, mas em geral exemplar bastante limpo, com algumas manchas de umidade e pequenos furos causados por insetos.

Franciscus de Mayronis, teólogo e fillosofo, viveu entre os séculos XIII e XIV; as inovações em seus sermões são modelos de habilidade e ousadia dialéticas e neles existem diversas referências à gastronomia, ao vinho e à embriaguez.

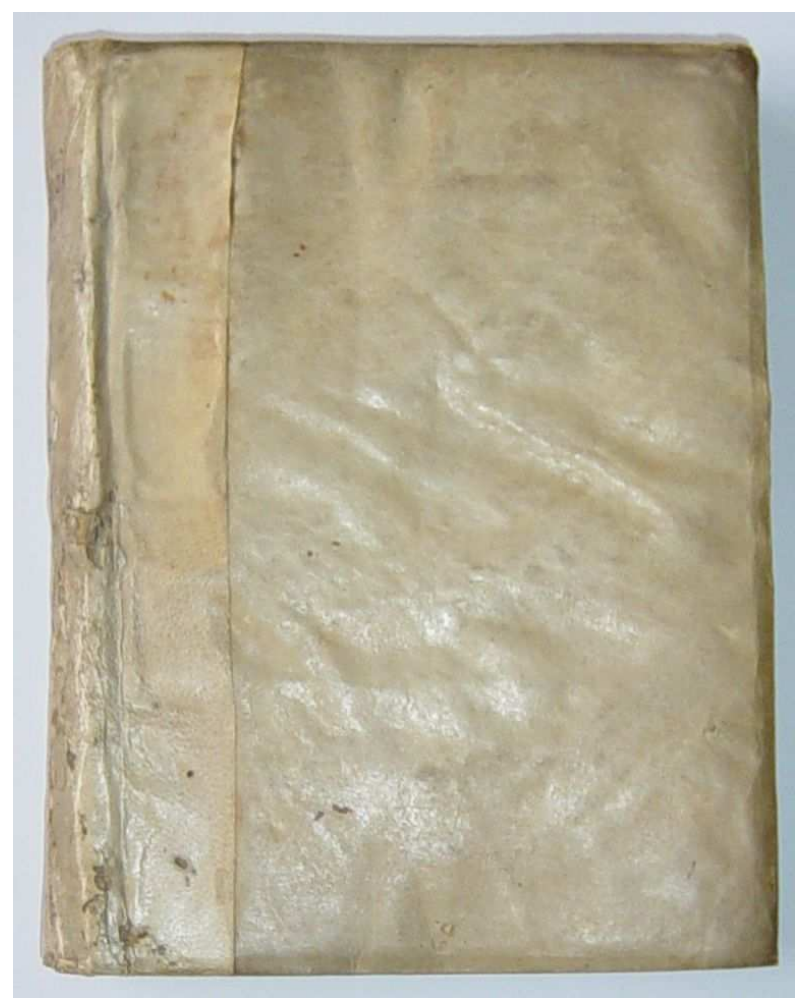

Fig. 32.3 - Detalhe da encadernação com a emenda de pergaminho. 


\section{3.}

\section{SENECA, Lucius Annaeus (ca. 4 a.C.- 65 d.C.)}

\section{Opera = Cinco libros de Seneca.}

Sevilha : Meynardo Ungut Alimano \& Stanislao Polono, 28 de maio de 1491.

[130] f. ; $27 \mathrm{~cm}$ (in fol.)

Texto em espanhol. Tradução e comentários: Alonso de Cartagena

Assinatura: $a-b^{8} c^{6} d-e^{8} f^{6} g^{8} h^{6} i^{8} k^{6} l^{8} m^{6} n-o^{8} p^{6} q-r^{8} s^{6}$

2 colunas (texto e glosas); 33-53 linhas; caracteres góticos [tipos: 1:82 G, 2:111 G].

Xilogravuras: iniciais e marca do impressor.

Filigranas: mão com flor

Conteúdo: De la vida bienaventurada, De las siete artes liberales, De amonestamientos y doctrinas, Primero [libro] de providencia de Dios, segundo libro de providencia de Dios.

Prólogo e inicial em vermelho na primeira folha.

Encadernação moderna em pergaminho, assinada: "Brugalla - 1946".

Assunto: Filosofia, literatura

Interesse vinário: História do vinho

Referências: BMC X 38; BN-RJ 191; Brunet V p.279; Escudero 20; Goff S-374; Graesse VI p.354; Haeber 621; HC 14596; IBE 5193; IBP 4971; Kurz 342; Mendes 1163, 1164; Palau VI p.490; Proctor 9528; Shepard 7307; Vindel V 23.

Banco de dados: CCPB 000112428-5; GW M41253; ISTC is00374000.

Exemplares conhecidos: 27 (3 imp., 1 frag.)

Outro incunábulo na BVR: $n^{\circ} 6$

Folha 1r: Cinco libros de Seneca. // Primeiro libro Dela vida bienauenturada. // Segundo delas fiete artes liberales. // terçero de amoneftamientos 7 doctrinas. // Quarto 7 el primeiro de providençia de dios. // Quinto el fegūdo libro de providençia de dios.

Folha 1v: branca

Folha $2 r$ (ass. $a_{i i}$ ): Prologo. // Libro de lucio anneo Seneca que efcriuio a Galion E llama // fe dela vida bien auêturada. trafladado de latin em lenguaje // caftellano por mandado del 
muy alto principe muy poderofo rey $\urcorner$ feñor nueftro feñor el rey don Juā de caftilla de le // on el fegūdo. Poren de el plogo dela traflaçiō fabla conel. // ( S xil. ${ }^{7}$ )I los bienes mundanos principe muy po // derofo. pueden dar bien andança perfec // etc.

Folha 52: branca

Folha 53r (ass. $h_{j}$ ): Prologo. // Aqui comiēça el libro de lucio anneo feneca. que fe lla // ma de prouidençia de dios a lucillo. trafladado de la- // etc.

Folha 130v: (5 linhas) // refplādefçer. Porq de todos fean acatados. // DEO GRACIAS. // Aquí fe acaban las obras de Seneca. Imprimidas enla // muy noble 7 muy leal cibdad de Seuilla. Por Meynar // do Ungut Alimano. т Staniflao Polono: conpañero/ // Enel año del nafçimiento del feñor Mil quatroçiētos // 7 nouenta 7 vnu años.aveinte 7 ocho dias del mes de // Mayo. // Marca tipográfica do impressor.

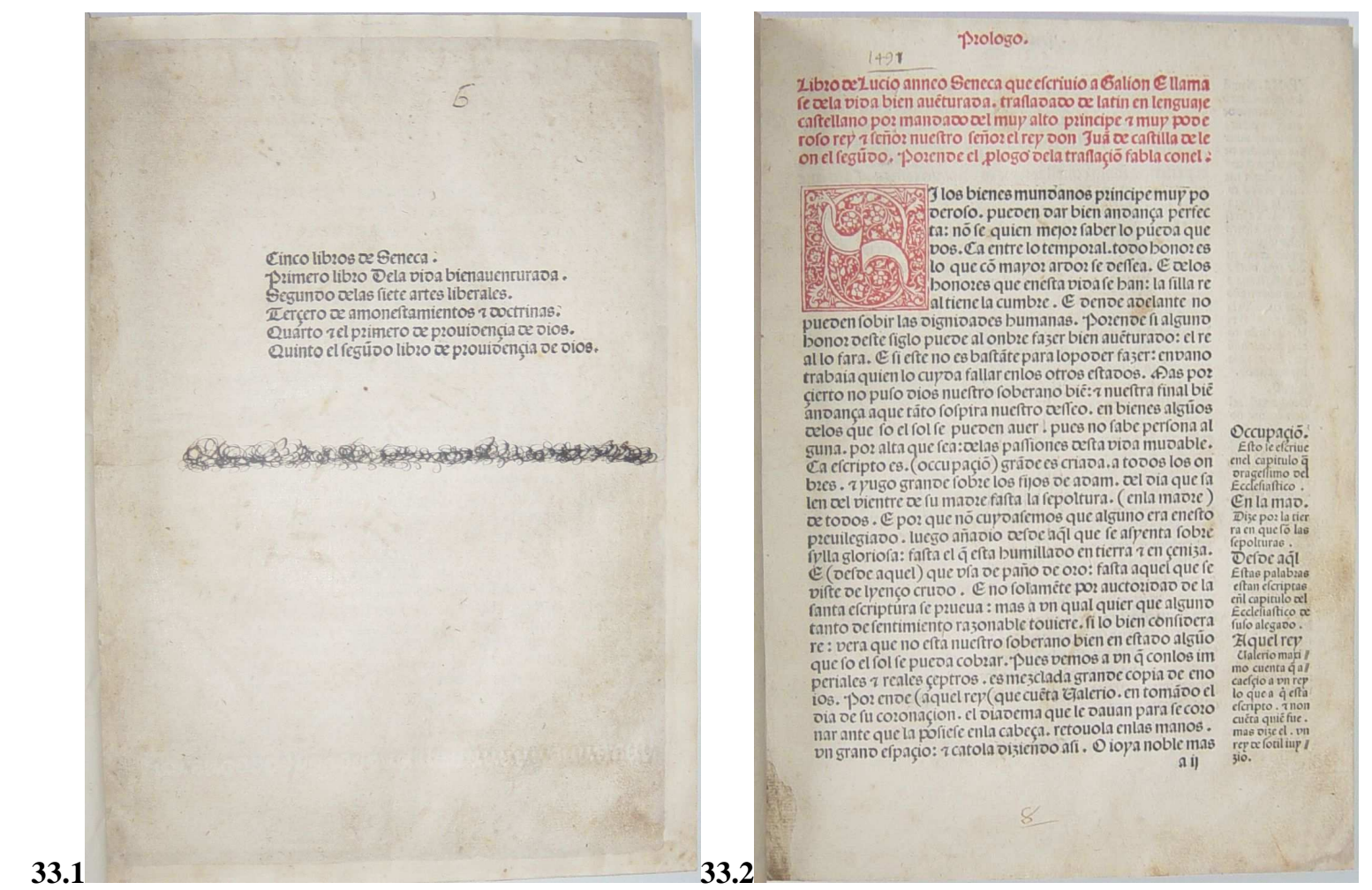

Fig. 31.1 e 33.2 - Folhas de abertura de Cinco libros de Seneca.

Este é o único incunábulo da coleção em língua espanhola. (Vale mencionar que Juan Carlos Reppucci, em conversa sobre a sua biblioteca, mencionou o interesse em priorizar a aquisição de obras em espanhol e português, mas dada a dificuldade de encontrá-los, entre os incunábulos só há este em espanhol e nenhum em português.)

Encadernação moderna em pergaminho, com douração de fios e florões na lombada e molduras nas capas; luva de proteção contemporânea à encadernação. Nota-se na folha de 
rosto e nas primeiras folhas que o exemplar foi restaurado, tendo a margem refeita. Emilio Brugalla (Barcelona, 1901-1987), não foi somente um grande encadernador espanhol, com muitas encadernações artísticas, mas também um estudioso da história do livro e da encadernação com livros publicados.

Os impressores desta obra iniciaram suas atividades em Sevilha neste mesmo ano com a obra Defensiones Sanctis Thomae, de Diego de Deza, datada de 4 de fevereiro. A sociedade continuou ativa até 1499, quando Meynardus Ungut se retirou e Stanislau Polonus seguiu trabalhando sozinho (SOSA, p.159). A marca do impressor neste livro é uma das primeiras encontradas em livros espanhóis. De acordo com Hugh William Davies (1935, p.198) a primeira vez que ela apareceu foi neste mesmo ano (provavelmente na obra anteriormente citada) e a marca que ele comenta consta no livro Processionarium ordinis praedicatorum (1494), que é idêntica a deste exemplar.
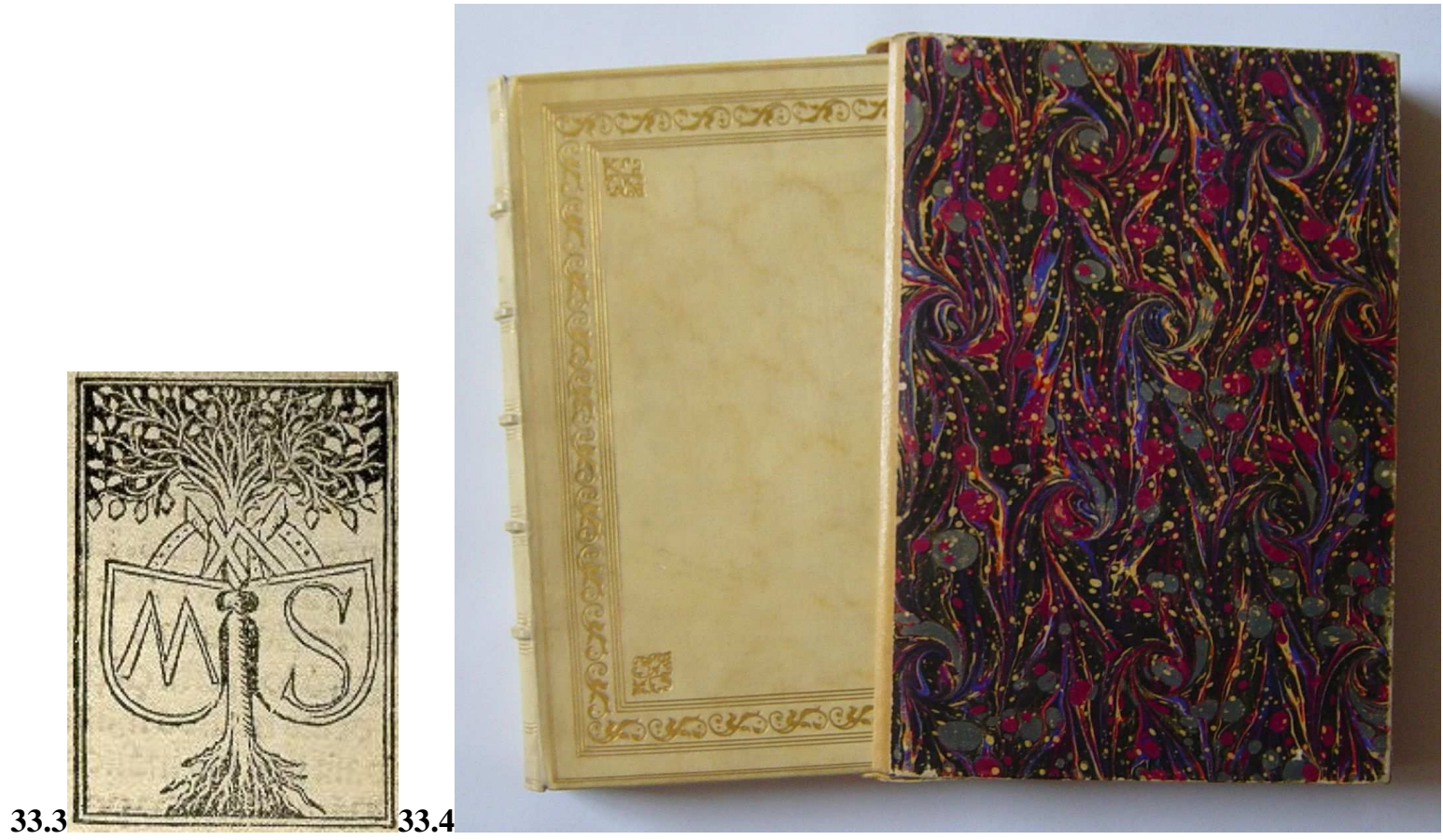

Fig. 33.3 e 33.4 - Detalhe da marca tipográfica do impressor e da encadernação em sua luva de proteção. 


\section{2}

\section{4.}

OVIDIUS NASO, Publius (ca. 43a.C.-17 d.C.)

\section{Opera.}

Veneza : Lazarus de Soardis, de Saviliano, 1492.

[290]f. ; 31,5 cm (in fol.)

Texto em latim.

Assinatura: $\mathrm{A}^{5} \mathrm{~B}-\mathrm{S}^{6} \mathrm{a}-\mathrm{z}^{6} \& \supset \pi^{6}$ aa-cc $\mathrm{cd}^{5}$

65 linhas; título corrente; caracteres romanos; espaço para iniciais; letras-guia; reclamos; registro, marca tipográfica do impressor em xilogravura.

Filigranas: balança

Exemplar com iniciais pintadas em azul e vermelho, encadernação moderna em pergaminho.

Assunto: Poesia

Interesse vinário: Baco, virtudes do vinho.

Referências Bibliográficas: BMC V 490 (II); Borm 2007; Brunet IV p.269; CIBN O-87; Coll(U) 1132; Goff O-136; Graesse V p.67; Günt(L) 3689; HCR 12163 + HC(+Add) 12146; Hillard 1501; IBE 4231; IBP 4074; IDL 3482; IGI 7050; Pell Ms 8828 (8693); Proctor 5282; Sajó-Soltész 2489 (II); Sheppard 4378 ; Walsh 2440.

Banco de dados: GW M28930 e M28599; ISTC io00136000.

Exemplares conhecidos: 34 (11 imp.).

Outro incunábulo na BVR: $n^{\circ} 36$

03074

Folha $\operatorname{lr}$ (ass. $A_{i i}$ ): PVBLII OVIDII NASONIS VITA // $\left(\mathrm{C}^{6}\right)$ Vm ufitatiflimū effe morē animaduerterim fplen // didiflime eques aurate Cicche Simoneta in exponē // dis auctoribus cuiufcunq; tandē u funt facultatis ut // etc.

Folha $6 r$ (ass. B): PVBLII OVIDII NASONIS METAMORPHOSEOS. // LIBER PRIMVS INCIPIT. // ( $\mathrm{I}^{7}$ )NNoua ferr animus mutatas dicere formas // Corpora: du cæptis: nā uos mutaftis \& illas: // etc. 
Folha 121r: (55 linhas) // Si quid habent ueri uatum præfagia: uiuam. // F I N I S // Publii Ouidii Nafonis Metamorphofeos Libri qntidecimi. // Venetiis per Lazarum de Seuiliano. // Mccclxxxxii.die.iii.Martii. // Regiftrum // A iiii B iiii ... S iiii // LAVS DEO Folha 121v: branca

Folha 122 (ass. a): Liber Heroidum // P. OVI. NASONIS SVLMONENSIS POETAE // CLARISSIMI HEROIDVM LIBER VNICVS. // $\left(\mathrm{h} \mathrm{H}^{8}\right.$ )ANC TVA PENELOPE LENTO // tibi mittit ulyxes. // etc.

Folha 290v: (31 linhas) // Liuia funeftam dedecet efle domum. // FINIS // Publii Ouidii Nafonis Sulmonenfis poetæ Clarifli- // mi Opera oīa Venetiis diligentiflime per Lazarum // de Sauiliano Impreffa funt. Anno a natali Chri- // ftiano. M.CCCCLXXXXII. Calendis Aprilibus. // REGISTRM. (sic) // a iiii b iiii ... dd iiii. finis. // marca tipográfica do impressor.

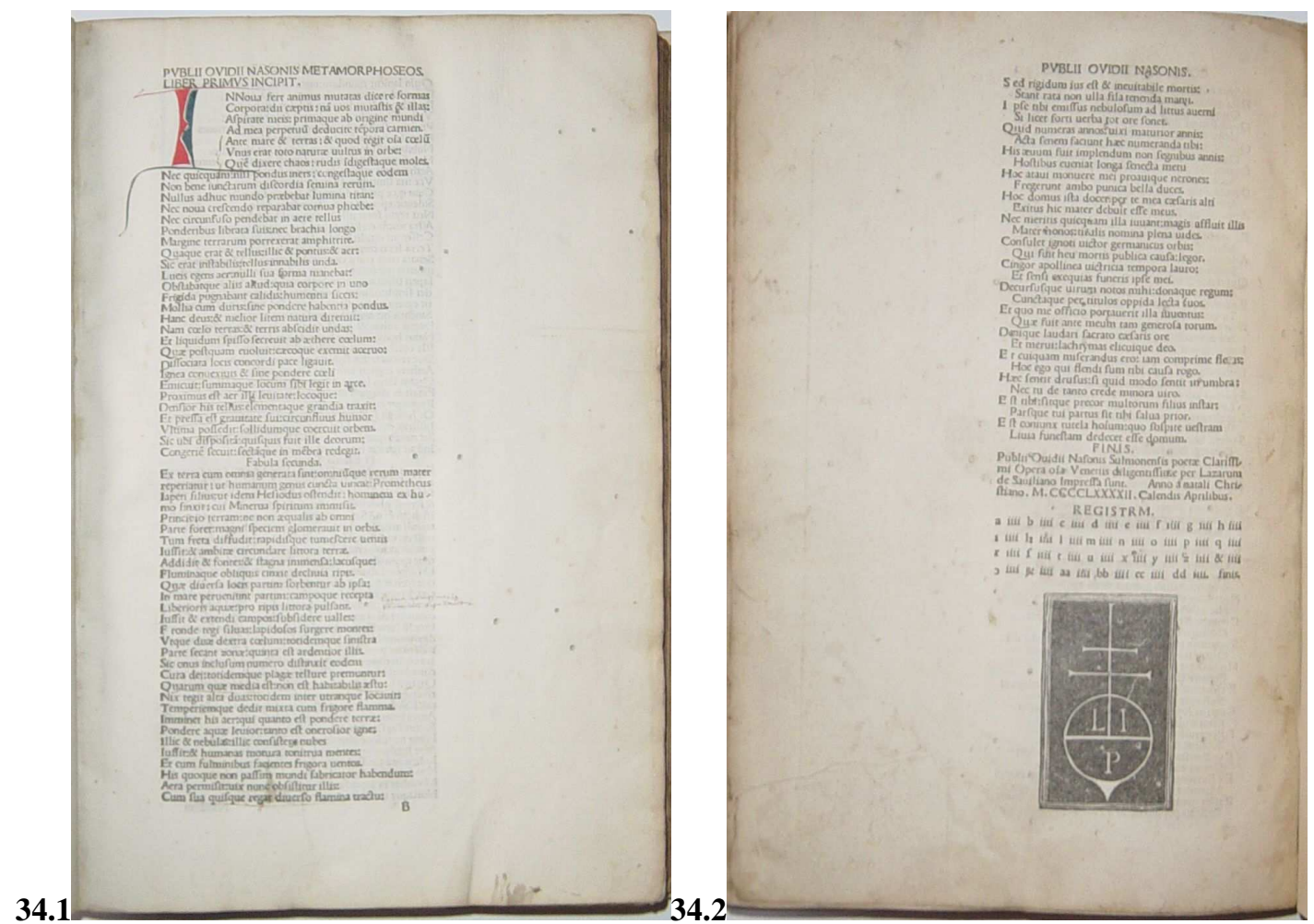

Fig. 32.1 e 34.2 - Página de abertura da obra de Ovídio (f. 6r) e página final (f. 290v).

Encadernação moderna em pergaminho, lombada com nome do autor manuscrito: "Ovid". Diversas folhas com anotações marginais e partes do texto sublinhado; oito folhas mutiladas na margem da frente, sem atingir o texto, e restauradas; faltam duas folhas, de 
acordo com as referências, a primeira que é branca e a última, que na frente tem Tabularum tabula... e no verso é branca.

Publius Ovídius Naso, foi educado em Roma e por influência do pai estudou retórica e direito, mas com sua morte desiste do direito e passa a dedicar-se à poesia. Em 8 d.C. foi exilado por Augusto por causa de sua obra Ars Amandi (Arte de amar), sobre sedução e intriga. Durante seu exílio em Tomis, que ele considerava a pior punição possível, continua produzindo até sua morte, sem nunca ter retornado a Roma.

Em sua poesia são inúmeras as passagens em que o vinho aparece, seja ao mencionar Baco, sua preferência pelo vinho espanhol, ou ao descrever os efeitos da bebida. ${ }^{39}$

\footnotetext{
${ }^{39}$ Ver na página 26 do texto introdutório a citação onde Ovídio exalta o vinho e seus efeitos.
} 


\section{3}

35.

MARTIALIS, Marcus Valerius (ca. 40a.C - 102a.C)

\section{Epigrammata. Martialis cum duobus commentis.}

Veneza, Bartholameum de Zanis, 13 de novembro de 1493.

[1], 2-159 f., folio $(28,5 \times 20,7)$.

Texto em latim, comentários de Domitius Calderinus e Georgius Merula

Assinatura: $a^{6} b-t^{8} u^{9}$

2 colunas (texto e comentário); 46-62 linhas; caracteres romanos; registro; iniciais xilogravadas.

Filigrana: Balança

Procedência: Syston Park, Mr.T. E.Watson (ex-libris)

Encadernação em pleno couro ricamente decorada com assinada: R. Storr, Grantham. Exemplar com anotações manuscritas de época.

Assunto: Poesia

Interesse vinário: História do vinho, virtudes do vinho.

Referências: Aquilon 461; BMC V 432; BSB-Ink M-201; CIBN M-172; Coll(S) 700; Goff M-311; Günt(L) 3860; HC 10823*; IBE 3799; IGI 6230; Oates 2082; Parguez 704; Pell Ms 7703 (7607); Polain(B) 4554; Proctor 5330; Torchet 637; Voull(B) 4250; Walsh 2254, 2255; Zehnacker 1517.

Banco de dados: GW M21294; ISTC im00311000.

Exemplares conhecidos: 82 (3 imp.).

Outro incunábulo na BVR: $n^{\circ} 46$

04381

Folha 1r: Martialis cum duobus // commentis. (folha com diversas anotações manuscritas) Folha $1 v$ : EPISTOLA // DOMITIVS CALDE.IO.FRAN.LODOVICI PRIN. MANTVANI FILIO SALVTEM. // ( $\mathrm{N}$ xil. 6)On fuiffent tot exēplis editi cōmētarii noftri: quos fupiore æftate emiferamus nifi tu magna // ... (33 linhas) // Dominitii Chalderini Veronenfis Commentarii in. M. Valerium Martialem ad clariflimum uirum Laurem // tium medicen: Florentinum Petri Medicis .F. // etc. 
Folha $2 v$ (n. 2, ass. aii), comentário: (51 linhas) // M. VALE. MAR. EPIGRAMMATA CVM DO. CHAL. AC GEO. ME. COMMENTARIIS. // ( B xil. ${ }^{5}$ )Arbara Pyramidū: Hoc prīo epigram // mate aftentatur Domitiano: cuius am // etc.

Texto: (52 linhas) // IN AMPHITHEATRVM CAESARIS // ( B xil. ${ }^{4}$ )ARBARA Pyramidum fileat $\mathrm{mi} / /$ racula memphis. // etc.

Folha 7 (n. 7, ass. b): M. Valerii Martialis Epigrāmatō Liber cū Domitii chalderint: ac Georgii merulæ cōmentariis. // ( S xil. ${ }^{5}$ )PERO me fecuturū: Scribit hoc nunc: ut demum fit editurus librum: \& hæc epiftola appo- // etc.

Texto: (6 linhas) // ( S xil. ${ }^{10}$ )PERO me fecutu $\pi$ in li- // bellis meis tale tēperamē // etc.

Folha 158r (n. 158), final do texto: (25 linhas) // Surgite iam uendit pueris ientacula piftor: // Criftatæ q3 fonant undique lucis aues. Final do comentário: (44 linhas) // a duabus autem rebus lucis aduentatis fignum accipit: $\&$ a pueris ementibus ientacula $\&$ a gallis canentibus: qui autore Plini. Geniti a natura funt ad excitādos mortales 1 opera: \& Tōnum rumpendum. // // Dimitii Chalderini Veronenfis defenfio cum recriminatione in calumniatorem cōmentariorum $\overline{1}$ Mar- // etc.

Folha 159v: (55 linhas) // in maledicta incurrere in quibus declinandis nō minus prudentiæ exiftit quam in ferendis moderationis. // REGISTRVM. // a b c d e f g h i k $1 \mathrm{~m} \mathrm{n}$ o p q r s t u. // Omnes funt quaterni preter a qui eft ternus:\& u quinternus. // Hoc per bartholameū de Zanis de portefio Venetiis impreffum opus fœliciter explicit. // .M.cccc.xciii. Die.xiii.Nouembris.

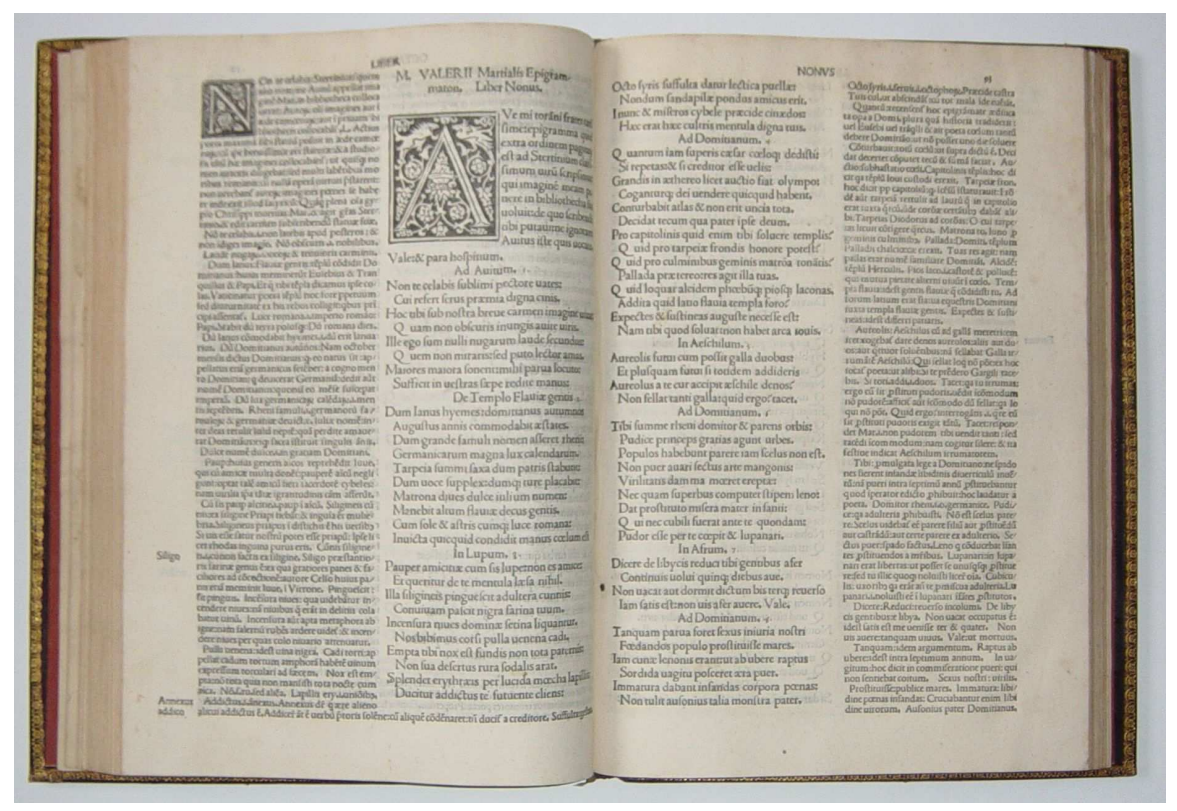

Fig. 33 - Detalhe da obra de Martialis: nas colunas centrais o texto em letra maior, nas colunas externas os comentários em letra menor. 
Encadernação em pleno marroquino, ricamente decorada com diversos fios trabalhados, fazendo uma moldura nas pastas; lombada com nervuras dourada com fios e florões. Na guarda da contra-capa há um selo do encadernador com os dizeres: "Bound by // R. Storr // Grantham". Belas capitulares xilografadas por toda a obra, sendo maiores para o texto e menores no comentário. Exemplar com anotações manuscritas de época, principalmente na folha de abertura e na folha final.

É curiosa a procedência desta obra Sir John Thorold (1734-1815), Barão de Marsdon, foi grande bibliófilo; sua biblioteca, Syston Park (em Lincolnshire, Inglaterra) ${ }^{40}$, foi importante coleção de incunábulos e aldinos ${ }^{41}$, e seu filho, Sir John Hayford Thorold (1773-1831) deu continuidade a sua coleção. Provavelmente o ex-libris "J.H.T." indica que foi uma aquisição do filho para a biblioteca Syston Park. E a encadernação deve ter sido encomentada a R. Storr por um deles, já que a cidade de Grantham pertence a Lincolnshire. Sabe-se que parte do acervo dispersou-se em leilão da Sotheby's em $1884^{42}$ e é possível que nesta ocasião esta obra tenha sido arrematada por "Mr. T. E. Watson".

Marcus Valerius Martialis, nasceu na Espanha no século I, e pouco de sabe ao certo de sua vida, apenas que foi ainda jovem para Roma e conviveu com grandes personagens da época. Deixou a obra Epigrammata, ou Epigramas: poesias breves, satíricas, em que o tema vinário é constante, seja falando de diferentes tipos de vinhos seja ao mencionar seu favorido (o Falerne da Itália), ou aludindo à conservação do vinho.

\footnotetext{
${ }^{40} \mathrm{O}$ artigo já mencionado do New York Times também fala da coleção de Syston Park (Anexo A).

${ }^{41}$ Nome dado à coleção de obras impressas por Aldo Manuzio.

42 Catálogo do leilão: The Syston Park Library: catalogue of an important portion of the extensive \& valuable library of the late Sir John Hayford Thorold, Bart. removed from Syston Park, Lincolnshire : which will be sold at auction : by Messrs. Sotheby, Wilkinson \& Hodge. London : Sotheby, Wilkinson \& Hodge, [1884]. (Venda em 12 de dezembro de 1884 e nos 7 dias seguintes).
} 
36.

OVIDIUS NASO, Publius (40 a.C. - 17 d.C.)

\section{Metamorfosis.}

Veneza, Bonetus Bocatellus, para Octavianus Scotus, 4-5 de junho de 1493.

[147]f., folio $(31,0$ x 20,5 cm.)

Texto em latim, comentários de Raphael Regius.

Assinatura: [5] A-R ${ }^{8} S^{6}$

2 colunas (texto e comentário); 46-62 linhas, tít. corr.; caracteres romanos; iniciais xiligrafadas; marca tipográfica do impressor.

Filigranas: balança e coroa (guarda).

Encadernação moderna couro posterior.

Assunto: Poesia.

Interesse vinário: Baco, virtudes do vinho.

Referências: BSB-Ink O-135; Goff O-188; HC 12172; IBP 4075; IDL 3473; IGI 7120; LQkkös(Cat BPU) 331; Madsen 2995; Oates 1970; Proctor 5044; Sack(Freiburg) 2639; Schmitt I 4180; Sheppard 4200; Voull(B) 4180; Voull(Bonn) 869; Walsh 2298.

Banco de dados: GW M 28921; ISTC io00188000.

Exemplares conhecidos: 33 (3 imp.).

Outros incunábulos na BVR: nº 34

00005

Folha 1: branca

Folha 2: branca

Folha 3r: Adilluftriflimum Matnuæ Principem Francifcum Gonzagam. // Raphaelis Regii enarrationum in Ouidii metamorphofin // ( C xil. ${ }^{4}$ )Ogitāti mihi iucūdiflime Priceps cui potiflimū meas in Ouidii metamorphofin // etc.

Folha $6 r$ (ass. a), texto: P. Ouidii Nafonis Sulmonenfis meta- // morphofeos Liber primus. ( I xil. $\left.{ }^{10}\right) \mathrm{N}$ noua fert aīus muta // tas dicere formas // etc. // Comentario: Raphaelis Regii in metamorphofin Ouidii enarrationes. // $\left(\mathrm{i}^{3}\right) \mathrm{N}$ noua fert animus. Cōfueuerūt heroici poetæ latini in prīcipiis ftatim ope $\pi$ fuo $\pi$ pponere primū // etc. 
Folha 146r, $2^{a}$ col.: Texto: (17 linhas) // Si quid habent ueri uatum præfagia uiuam. // Finis // Comentátio: (14 linhas) // perat orbe relicto. ordo eft. relicto orbe quē tēperat. // Venetiis impreffum Per Bonetum Locatellū: man- // dato \& expēfis nobilis uiri Octauiani Scoti Modoe- // tienfis. Anno falutis. M.CCCC.LXXXXIII. Nonis // luniis. // Bartholomeus Merula Generofo Adolefcenti Frācifco. Georgii Cornelii eqtis præclariflimi filio Salutē. // etc. (19 linhas) // to. Vale. Venetiis. MCCCCLXXXXIII. pridie nonas lunias.

Folha 146v: Registrum // A // Raphaelis regii. // etc. // finis. // marca tipográfica do impressor.

Folha 147: branca

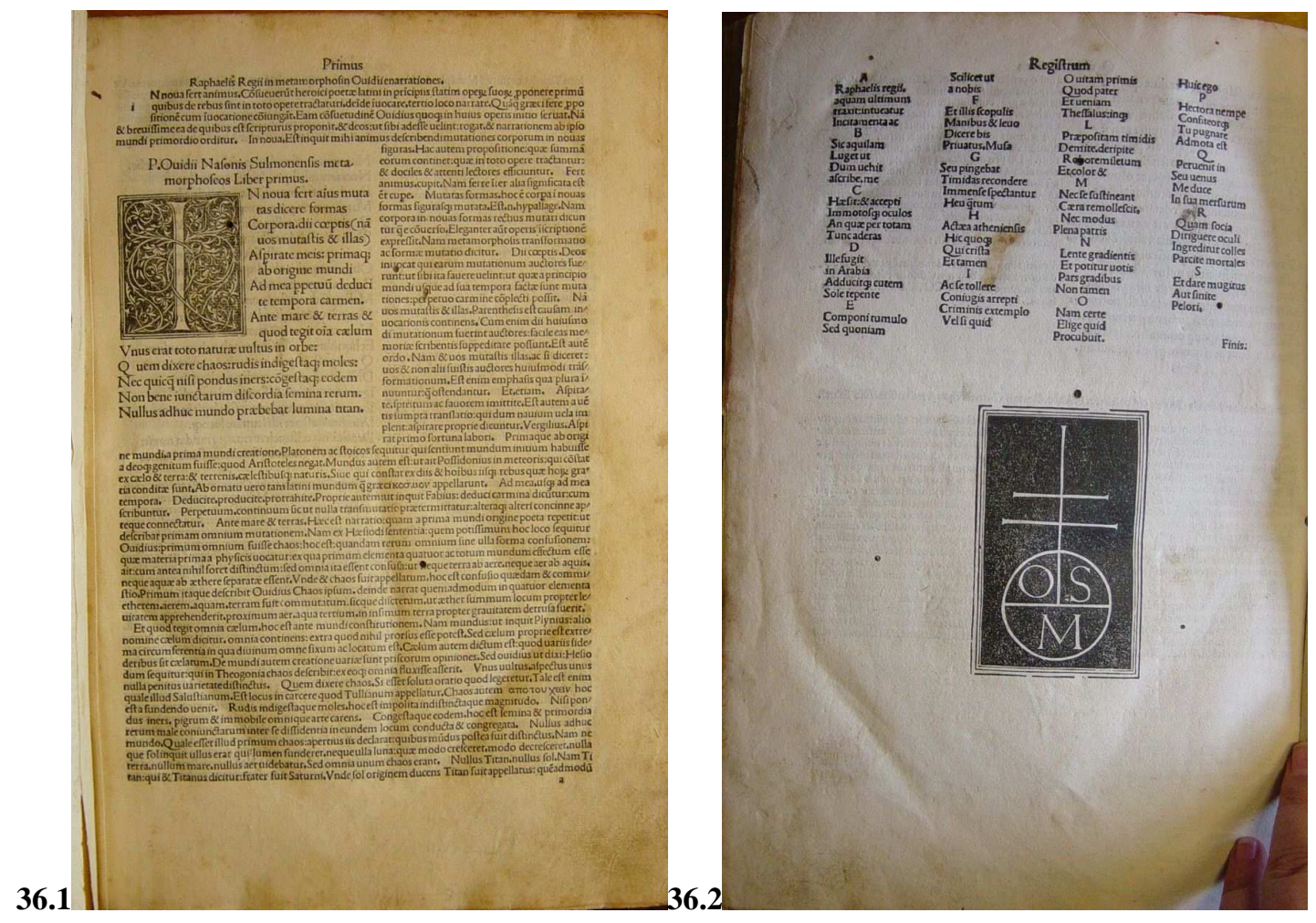

Fig. 34.1 - Página de abertura do primeiro livro (f. 6r).

Fig. 36.2 - Página final com registro e marca tipográfica do impressor (f. 146v).

Exemplar com encadernação moderna em pleno couro decorada com gravação a seco. 
37.

\section{SCHEDEL, Hartmann (1440-1514)}

\section{Líber chronicarum = Das Buch der Croniken und Geschichten.}

Nuremberg : Anton Koberger, 23 de dezembro de 1493.

[10]f., 286f., [1]f., paginado de [10] Blat .j. - CCLXXXVI., folio $(41,5$ x 29,0 cm). Texto em alemão. Tradução de George Alt.

Assinatura: $\left[a^{10} b^{6} c-e^{4} f-i^{6} k^{2} l^{4} m-o^{6} p^{2} q-r^{6} A-C^{6} D^{8} E^{6} F^{4} G-Z^{6} a a^{4} b b^{6} c c^{4} e e-g g^{6}\right.$ $\left.\mathrm{hh}^{7}\right]$

1 e 2 colunas; $n^{\circ}$ de linhas variáveis; caracteres góticos.

Exemplar com margens pequenas, corte atingindo o texto na parte superior de algumas folhas, (o exemplar da BN mede $47 \mathrm{~cm}$., o que comprova o quanto este exemplar perdeu de margem).

Filigrana: coroa, letra "P".

Inúmeras gravuras e dois mapas, algumas gravuras coloridas à mão.

Gravadores: Michael Wolgemut, Wilhelm Pleydenwurff, [Albrecht Durer].

Encadernação em couro.

Assunto: História

Interesse vinário: História do vinho.

Referências: BMC II 437; Borm 2414; BSB-Ink S-197; Campbell(Maps) 219-220; C. Reske, Die Produktion der Schedelschen Weltchronik in Nürnberg. Wiesbaden 2000; CIBN S-163; Coll(S) 966; Coll(U) 1337; Ernst(Hannover) 301; Finger 871, 870; GfT 1165; Goff S-309; Günt(L) 2071; Hain 14510*; Hubay(Augsburg) 1861; Hubay(Eichstätt) 926; IBE 5181; IBP 4943; IDL 4062; IGI 8830; IJL 264; Klebs 890.1; Madsen 3637; MittlerKind 809, 810; Ohly-Sack 2530, 2531, 2532; Pell Ms 10354; Polain(B) 3471; Proctor 2086; Richard 450; Sack(Freiburg) 3184, 3185, 3186; Sajó-Soltész 3041; Sallander 1337 bis; Schäfer 310; Schmitt I 1746; Schr 5205; Schramm XVII p.9; Sheppard 1523; Voull(B) 1746; Voull(Trier) 1096; Walsh 734, 735; Wilhelmi 547; Zehnacker 2070.

Banco de dados: GW M40796; ISTC is00309000.

Exemplares conhecidos: 252 (40 imp., 7 frag., 1 perd.) 
Folha 1r, título xilogravado: Regifter Des // buchs der Cro- // niken vnd gefchichten // mit figurē vnd pildnǔ // sem von anbegiñ der welt // bis auf dife vñfere Zeit

Folha 1v: branca

Folha $2 r, 1^{a}$ col.: [ ${ }^{6}$ ]Aron ein bruder mo // yfi vnd hǒhfter bifchoff // XVIII // etc.

Folha 10v, $2^{a}$ col.: (56 linhas) // Zwayūg od' fcifma dz ${ }^{3}$ drit het anfang CXXXI // Item mer CXLII Das.xxij. ift defzmals gefche // hen CCXXXII // Die vbrigen hie nit angefagt finftu vnder dē bůch // ftaben oben $\mathrm{C}$ vnd $\mathrm{S}$.

Folha 11 (Fo. .j.): Ein kurtze befchreybung des wercks der fechs tag von dem gefchỏpff der werlt die vorrede. // [ $\left.{ }^{9}\right]$ Jeweill bey den allergelertiftē vnd fưrnamftē mannē die die warē natur vnd gefchicht befchri // etc. Ttermina na linha 68: tag lere : das wollen wir kůrtzlichen erzelen.

Folha 11v: Gravura de página inteira representando Deus-Pai com a inscrição: Ipfe dixit et fcā fūt iñe mādau ${ }^{\mathrm{t}} \mathrm{T}$ creata lūt Ps 32.

Folha $12 r$ (Blat II): ( $\mathrm{I}^{2}$ )n dem fang hat got befchaffen himel vñ erden aber die erde was eytel vnd lere, vnd die finfternus war // etc.

Folha $272 r$ (Blat CCLXII): Gravura de página inteira representando o juizo final, com o título: derwerlt.

Folha 272v: (37 linhas) // heit, gewalt, hayl. Kraft. Tugent vnd glori zu ewiger danckperkeit gefagt in die ewigkeit der ewigkeit. Amen. // Auß gỏtlichem beyftand endet fich alhie das bůch von den gefchihten der alter der werlt // vnd von befchreibung der berůmbtiften ftett fagende durch Georgi // um alt deßmals lofungfchereiber der kaiferlichē reichßftatt Nůrmberg auß latein in teůtfch // gebracht vnd befchloßē nach der gepurt Chrifti Jhefu vnßers haylands. M.cccc.xciij. iar // am fůnften tag des monats Octobris. // Altithrono fint perpetue lands.ag.alt.

Folha 273 (Blat CCLXIII): [ ${ }^{2}$ ]Iewol allereft nach befchlufs des bůchs vns die nachfolgenden befchreybungen des Polnifchen lannds // Auch der ftett Kraka Lůbeck vnd Neyfs zu komen find yedoch haben wir diefelben als neben andern gů- // etc.

Folha 297v: Hie ist entlich beschloffen das bůch der Cronicken vnd gedechtnus wirdigern // geschihtē vō anbegyñ d' werlt bis auf dife vnßere zeit vō hohgelertē mannē in // late3in mit großem fleiß vnd rechtfertigung verfamelt. Vnd durch Georgium al // ten deßmals lofungfchreiber zu Nůrmberg auß dēselben latein zu zeiten von maynung zu maynung vnnd beyweylen (nit on vrfach) außzugs weife in difs teůtsch gebracht.vnnd darnach durch den erbern vnnd achtpern Anthonien // koberger dafelbft zu Nůrmberg gedruckt auf anregūg vnd begern der erbern // vnd weysen Sebalden schreyers vnd Sebastiañ kamermaifters 
burgere da // felbft. vnd auch mitinhangung Michael wolgemůtz vnnd Wilhelm pleyden // wurffs maler dafelbft auch mitburger die difs werck mit figuren wercklich ge // ziert haben. Volbracht am.xxiij. tag des monats Decembris Nach der gepurt // Crifti vnßers haylands M.cccc.xciij. iar.

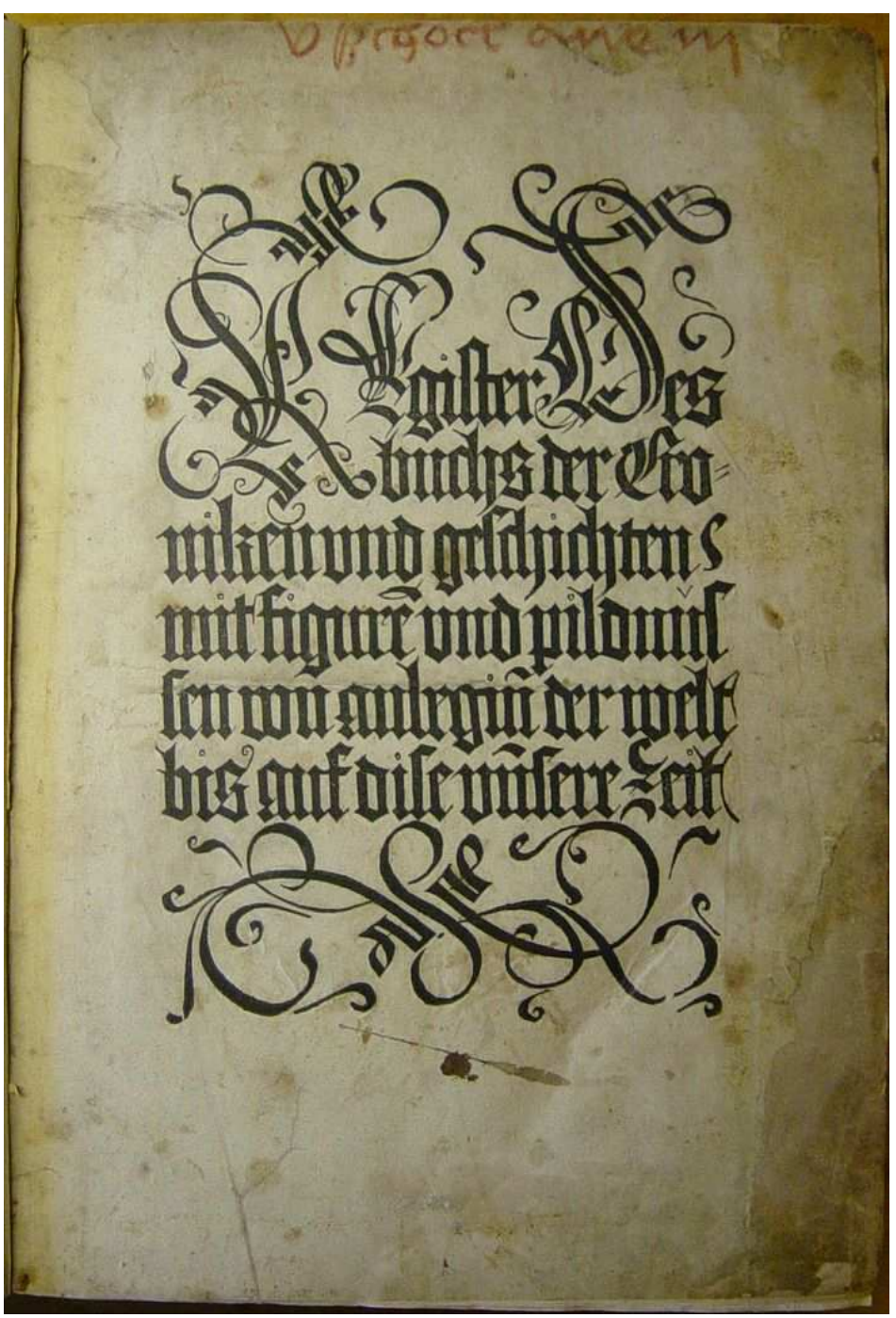

Fig. 35.1 - Folha de abertura de com título xilografado (f. 1r).

Das obras aqui apresentadas da BVR, esta é a mais famosa, também conhecida como As Crônicas de Nuremberg. Com freqüência é citada nos catálogos de coleções particulares ou bibliotecas públicas, como na Biblioteca de José Mindlin, da Biblioteca Nacional, no Rio de Janeiro, que possui cinco exemplares (quatro em latim e um em alemão), ou no acervo de obras raras da Universidade de São Paulo, sendo o único incunábulo dessa instituição. O sucesso que experimentou no século XV se estende até nossos dias, o que, aliado à sua riqueza iconográfica, propiciou com certeza que muitos sobrevivessem e sejam encontrados em quase todas as bibliotecas importantes pelo mundo. 
Trata-se de uma história universal profusamente ilustrada: estima-se que sejam aproximadamente 645 matrizes xilográficas, sendo que se repetem, chegando a 1809 imagens; algumas referências bibliográficas chegam a mencionar mais de 2500 ilustrações. Das obras estudadas aqui, está é a única em que se conhecem os gravadores: Michael Wolgemut, Wilhelm Pleydenwurff e acredita-se que Dürer também tenha participado do projeto.
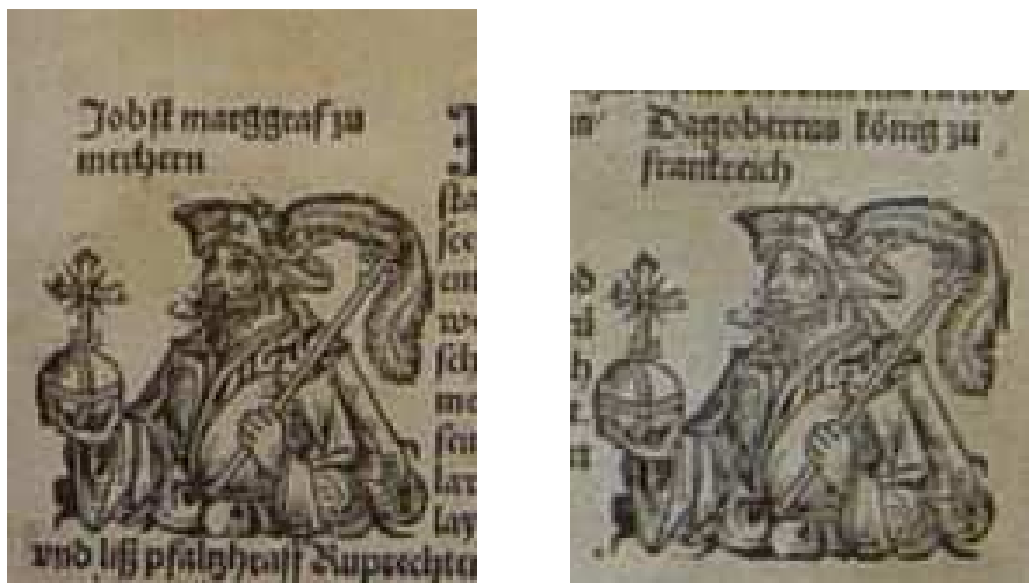

Fig. 37.2 e 37.3 - A repetição de gravuras acontece principalmente com os personagens; há também um bloco de cidade que se repete várias vezes, assim como gafanhotos e a simbologia do vento.

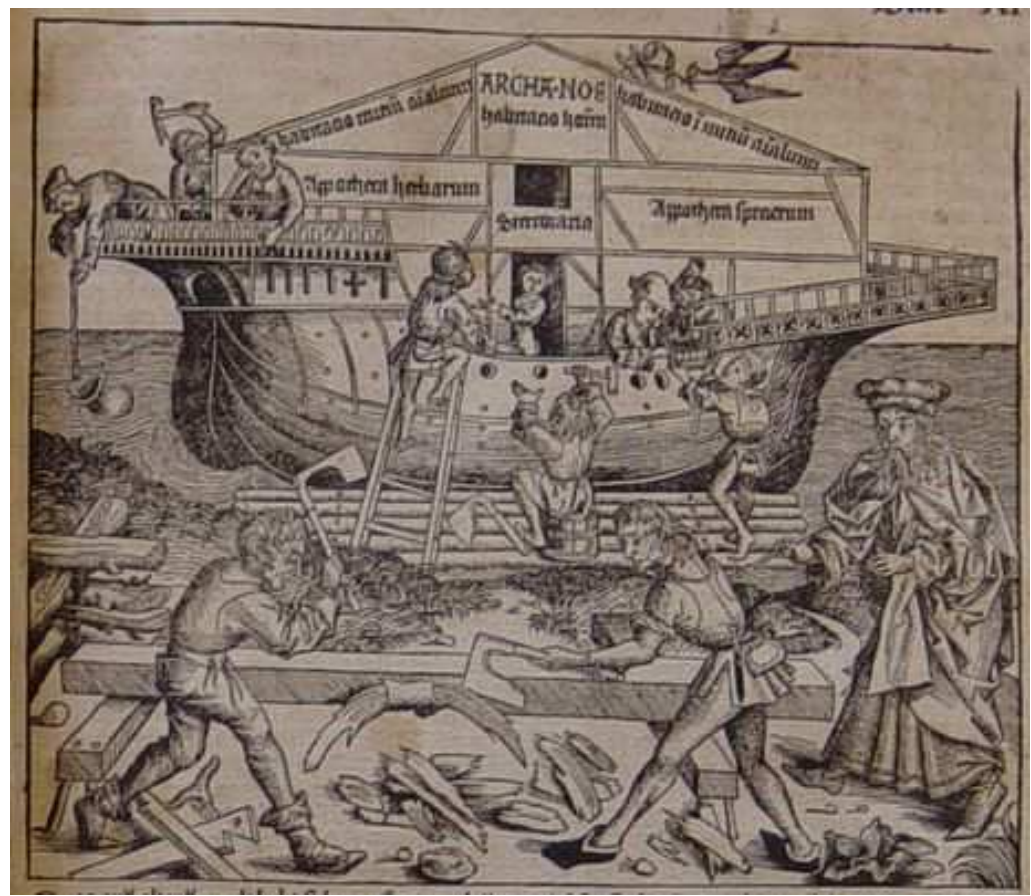

Fig. 37.4 - Xilogravura Bíblica: A arca de Noé (Blat XI).

Além das pequenas imagens que se repetem com frequiência, chamam a atenção as grandes gravuras que representam cenas da Bíblia, cenas históricas, cidades européias. 
Também merece destaque a representação das cidades mais importantes da época. Por exemplo, Nuremberg é a que tem maior destaque, ocupando sozinha duas páginas, enquanto cidades importantes da Europa da época, como: Roma, Veneza, Florença, Colônia, Estrasburgo e Constantinopla no Oriente ocupam a metade de duas páginas; e Espanha, Portugal e Damasco, apenas meia página.

Já o destaque deste exemplar específico, fica por conta das três páginas coloridas à mão. A primeira é da cidade de Ferrara, seguida pela cidade de Herbipolis e na página seguinte pela representação de três Papas.

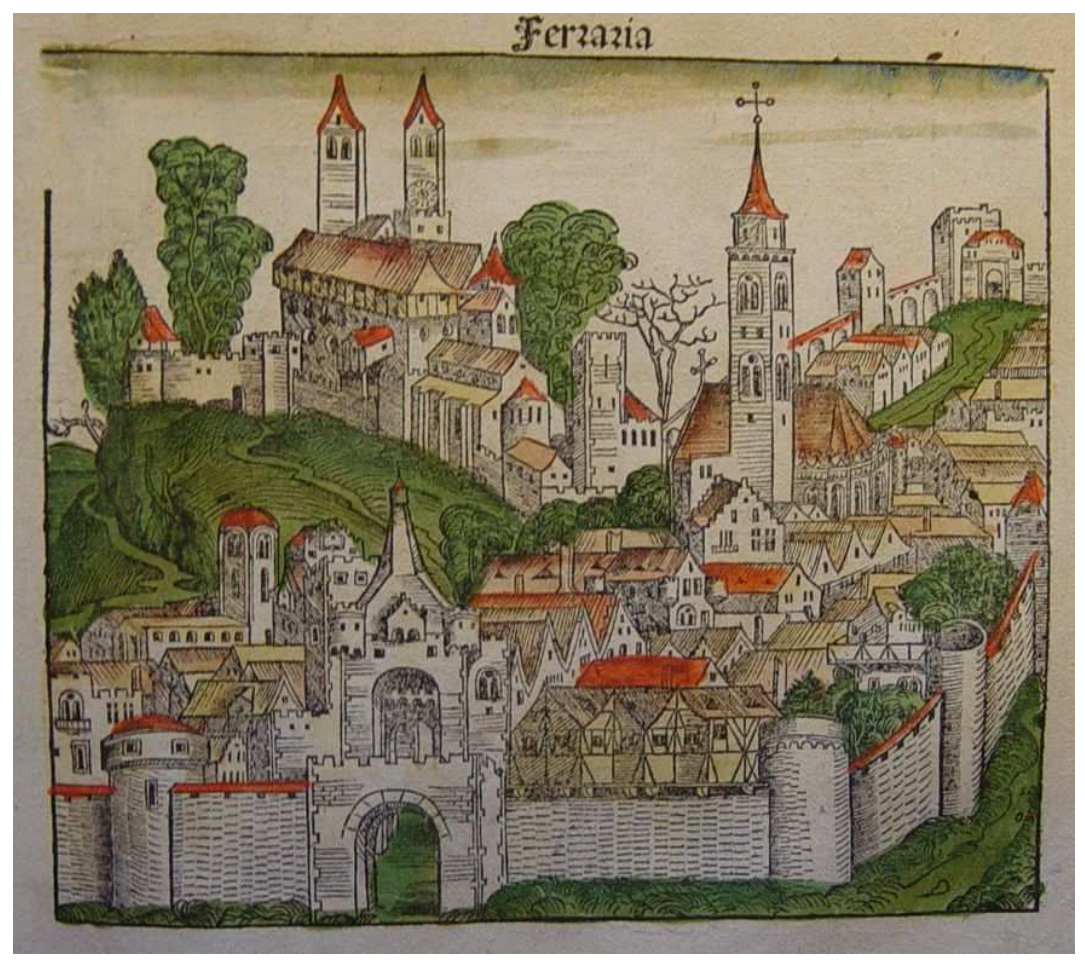

Fig. 37.5 - Exemplo de uma das xilogravuras coloridas, cidade de Ferraria. 
38.

SUETONIUS TRANQUILLUS, Caius (ca. 70 - ca. 140)

Viate XII Caesarum = De vita XII caesarum, cum commentario ant sabellici.

Veneza : Damiano de Mediolano, 1493.

[1], 2-129, [1]f.; $31,7 \mathrm{~cm}$ (in fol.)

Texto em latim. Comentários de Marcus Antonius Sabellicus. Acresc.: Marcus Antonijnus Sibellius: Epistola Augustino Barbadico; Vita Suetonii. Ausonius: Versus.

Assinatura: $a^{8} b-u^{6} x^{8}$

2 colunas (texto e comentário); caracteres romanos e gregos; espaço para iniciais; letras-guia; reclamos; registro.

Filigranas: balança, âncora, brasão (guardas).

Procedência: assinaturas não identificadas na folha de abertura.

Encadernação em pergaminho antiga (provavelmente do século XVIII), com brazões a seco nas capas, nervos aparentes e inscrição manuscrita na lombada. Pergaminho rompido junto à lombada, mas sem perda.

Assunto: História

Interesse vinário: História vinho

Referências: BMC V 543; BSB-Ink S-616; Brunet V p.581; CIH 3157; Goff S-824; Graesse VI p.520; HC 15124; IBE 5363; IBP 5130; IDL 4243; IGI 9237; Madsen 3800; Mendes 1193; Oates 2143; Polain(B) 3629; Proctor 5512; Sajó-Soltész 3157; Voull(Bonn) 1097; Walsh 2597, 2598 ; Zehnacker 2168.

Banco de dados: GW M44233; ISTC is00824000.

Exemplares conhecidos: 76 (3 imp.).

01132

Folha 1r: Suetonius cum // commento

Folha 1v: branca

Folha $2 r$ (ass. $a_{i i}$, num. 2): M. ANTONIVS SABELLICVS AVGVSTINO BARBADICO SERENISSIMO VENETIA // RVM PRINCIPI SALVTEM. // $\left(\mathrm{n}^{3}\right)$ Ihil eft omnino in tua florentiflima repub.a qua ego contempla nda nunq mentis oculos auerto // etc. 
Folha $2 v$ : M. ANTONII SABELLICI IN C. SVETONII TRANQuILLI PARAPHRASIM PROEMIVM // $\left(\mathrm{f}^{3}\right)$ olebā ego fæpe mecū reputare etc.

Folha $3 r$ (ass $a_{i i}, n$. 3): M. ANTONII SABELLICI AVGVSTINVM BARBADICVM: SERENISSIMVM VE- // NETIAR VM PRINCIPEM PARAPHRASEOS IN. C. CAESAREM DICTATOREM PARAE // NESIS PRIMA. // Texto: CAII SVETONII TRANQVILLI DE VITA // DVODFCIM CAESAR VM LIBER PRIMVS // Cæfar Dictator // ( $\left.\mathrm{a}^{7}\right)$ NNVM agens Cæfar fextūdeci- // etc. Comentário: $\left(\mathrm{a}^{2}\right)$ NNVM AGENS CAESAR: Sunt ni fallor uirtutes omnes in omnibus: ut uitia Auguftine // etc.

Folha $23 r$ (ass. $d_{i i i}, n .23$ ): M. ANTONII SABELLICI AD AVGVSTINVM BARBADICVM SERENISSIMVM VENE- // TIAR VM PRINCIPEM PARAPHRASEOS IN AVGVSTVM PARAENESIS SECVNDA // Texto: C. SVETONII TRANQ VILLI. D. OCTAVI- // VS CAES. AVGVSTVS. // [ $\left.{ }^{4}\right]$ Entē Octauiā uelitris pcipuam olim fuiffe mul // etc. Comentário: [ ${ }^{3}$ ]Octauiam gentē: Quāta in cōparando princiátu fuit dictatoris cæfaris felicitas: tāta quidē dux illu // etc.

Folha 129 (n. 129): 31 linhas // poft fe lætioremq portendi Reipublicæ ftarū. Sicut fane bre // uieuenit abftinentia \& moderatione infequentium principū // C. Suetonii Tranquilli de uita.xii.Cæfarum libri duodecimi // acultimi // FINIS. // Comentário: 42 linhas // it: ut in comgratulatione principu // acclamari fit folitū : Felicior Au- // gufto Traiano Melhor. // FINIS.

Folha 129v: Tetraftica de Cæfaribus poft Tranquilum. // Nerua imperator. // etc.

Folha 130r: TRANQVILLI VITA PER SABELLICVM. // C.Suetonius Tranquillus Suetonium lenem patrem habuit unde4 cognomen \& fi diuerfa uoce integro // ... (21 linhas) // Regiftrum huius operis. // a // Prima alba // etc. (27 linhas) // Venetiis per Damianum de // Mediolano.M.cccc. // lxxxxiii.die.xxix. // mēfis Martii.

Folha 130v: branca

Bela encadernação do século XVIII em pergaminho, rígida, com nervuras salientes na lombada e florão gravado a seco no centro de ambas as pastas. Apresenta-se desgastada, com o pergaminho rompido junto à lombada, mas sem perdas. Papel com boas margens, e anotações manuscritas em diversas folhas.

Esta edição possui variações aparecendo o nome do impressor no colofão como Damianus de Gorgonzola, diferente do nosso exemplar. 


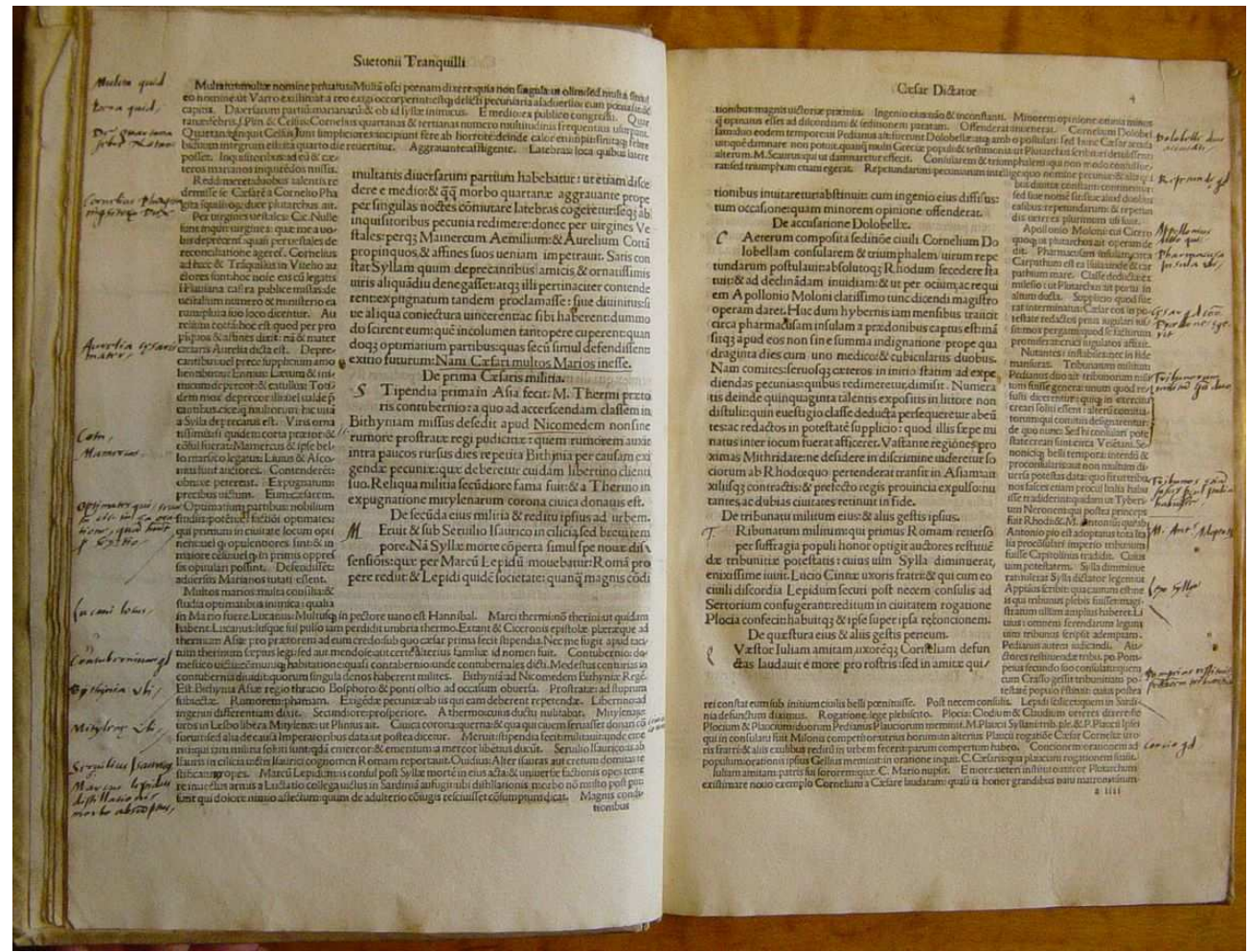

Fig. 36 - Detalhe da variação de tamanho do texto e comentário, presença de diversa as anotações manuscritas.

Suetonius, notável escritor e historiador latino, foi grande estudioso dos costumes e dos personagens de sua época. De suas obras a que sobreviveu mais completa é esta biografia dos imperadores romanos, importante relato da vida cotidiana do período retratando curiosas passagens que remetem ao vinho na antiguidade, como ao citar a preferência de Augusto pelo vinho Rheticum ao Falerne, ou de Tibério pelos vinhos de Chios e Domitien. 
39.

TIBULLUS, Albius (ca. 54 - 19 a.C.)

Elegiae. Acresc.: Catullus: Carmina e Propertius: Elegiae = Tibullus, Catullus \& Proptius cum comento.

Veneza : Simon Bevilaqua, 26 de junho de 1493.

158f. ; $31 \mathrm{~cm}$ (in fol.).

Texto em latim. Comentários de Bernardinus Cyllenius Veronensis, Antonius Parthenius e Filippus Beroaldus.

Assinatura: $a-c^{8} d-e^{6} f-s^{8} t-x^{6}$

2 colunas (texto e comentário); 46-62 linhas, tit. corr.; caracteres romanos; registro.

Filigrana: balança

Encadernação moderna em pleno couro, assinada; "ANGULO", com luva de proteção.

Assunto: Poesia

Interesse vinário: Baco, embriaguez

Referências: Arnoult 1427; BMC V 517; CIBN T-279; Goff T373; Günt(L) 3134; HC 4764; Hillard 1975; IBE 5540; IBP 5370; IDL 4453; IGI 9666; Madsen 3970; MittlerKind 614; Oates 2093; Pell Ms 11111; Polain(B) 4767; Proctor 5382; Sajó-Soltész 3328; Schmitt I 4390; Sheppard 4462; Voull(B) 4390; Walsh 2512; Zehnacker 2277.

Banco de dados:GW M47021; ISTC it00373000.

Exemplares conhecidos: 97 (6 imp.)

04525

Folha 1r: Tibullus Catullus \& // Proptius cū comento.

Folha 1v: TIBVLLI // Ber nardinus Veronenfis clariflimo uiro Baptiftæ Vrfino ærarii pontifi. cultodi. // etc.

Folha 37r (ass. f): PROEMIVM IN CATVLLVM. // ( a 4)Nronius Parthenius Lacifius Veronēfis Iuliu Pōponio falutem. Pleriq3 ciues mei optimi:atq3 cla- // etc.

Folha $77 r$ (ass. l): LIBER PRIMVS // Ad magnificum Minum Rofcium Philippi Beroaldi Bononienfis Commentarii in Propertium. // etc.

Folha 157r, final: Commentarii in Proptiū a Philippo Beroaldo // editi Anno falutis. Imprefēum Venetiis p Sy- // monē beuilaqua Papienfem. M.cccc.lxxxxiii. // die.xxvi. menfis 
lunii. // Sit Charifte Rex piiflime // Tibi patriq3 gloria // Cum fpiritu paraclito // In fempiterna fæcula.

Folha 157v: Hieroymi Salii fauētini $\overline{1}$ inuidum carmen. // ... (19 linhas) // Ne timeas: Mino uindice tutus eris. // REGISTRVM // a // Tibullus Catullus // etc. Final: // confolatur: recēfet // EINIS (sic).

Folha 158: branca

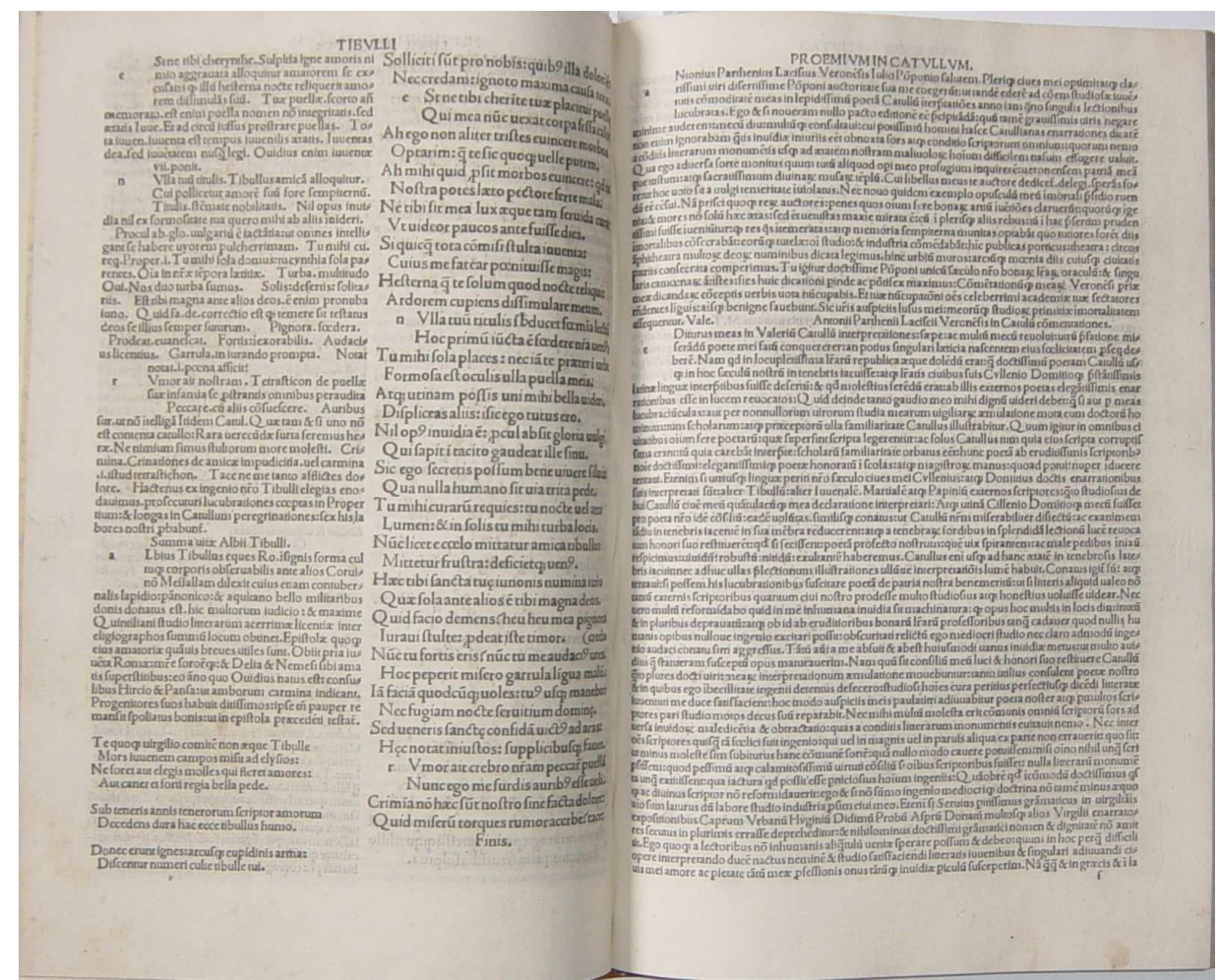

Fig. 37 - Detalhe onde se vê à esquerda duas colunas (texto e comentário), e na página à direita somente uma coluna (o comentário ocupa todo espaço).

Bela encadernação do século XX, em pleno couro castanho claro, lombada com nervuras e pastas decoradas com ferros a seco, cortes marmorizados semelhantes às guardas, e bordas internas das pastas com barra dourada. Encadenação assinada: "ANGULO", e luva de proteção. O exemplar encontra-se bastante limpo, com pouquissimas anotações e o papel apresenta indicios de ter sido restaurado. Na BVR há outra obra, de Valerius Maximus ( $n^{\circ} 42$ ) com encadernação semelhante e que leva a mesma assinatura.

Simon Bevilaqua, iniciou suas atividades como impressor em Vicenza, publicando três obras entre os anos de 1487 e 1491. Em 1492 mudou-se para Veneza, onde obteve maior êxito como impressor; até 1500 publicou aproximadamente trinta e nove livros e esteve ativo até 1518. 
Os três autores, Albius Tibullus, Caio Valerius Catullus (ca.84-54a.C.); Sextus PROPERTIUS (47a.C.-15 d.C.), são renomados poetas latinos, mas somente as obras de Catulo e Propertius fazem referências vinárias: várias passagens do texto citam o vinho, Baco, a embriaguez. 